

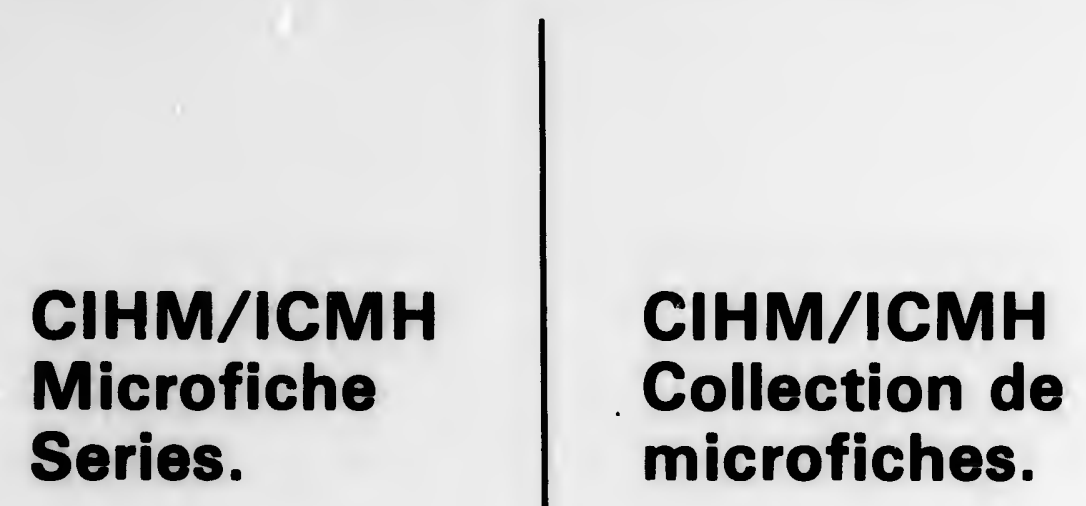

Canadian Institute for Historical Microreproductions / Institut cenadien de microreproductions historiques
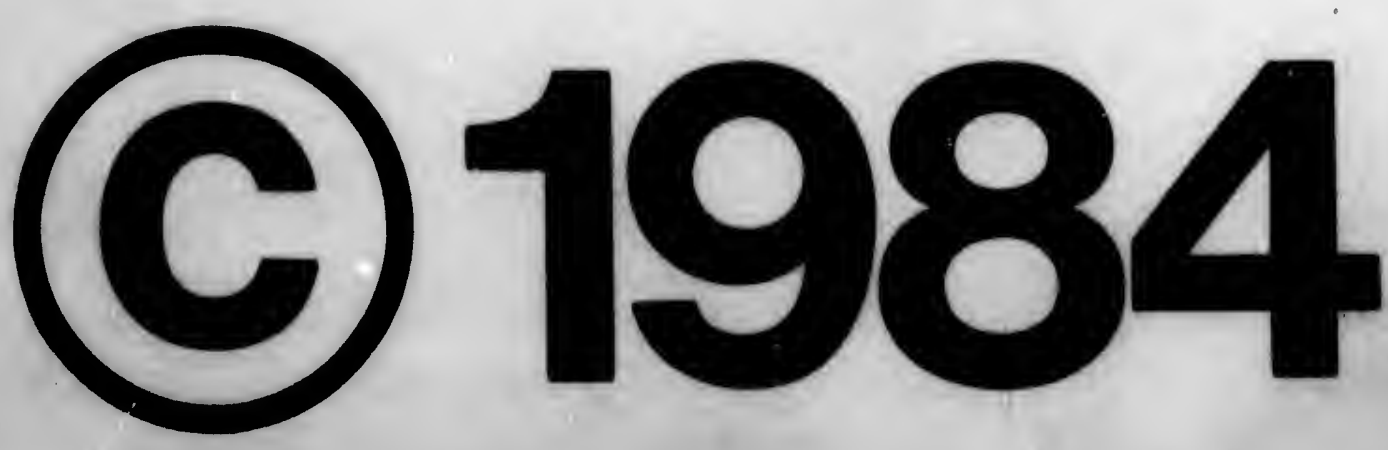
The Institute has attempted to cbtain the beat original copy available for fliming. Foatures of this copy which may be bibilographically unique. which may alter any of the images in the reproduction, or which may significantly change the usual method of fliming, are checked bolow.

Coloured covers/

Couverture de coubur

Covers damaged/

Couverture endommaghe

Covers restored and/or laminated/

Couverture resteurbe ot/ou polliculice

Cover titie miasing/

Le titre de couverture manque

Coloured maps/

Cartes gbographiques en couleur

Coloured ink (i.e. other then blue or black)/

Encre de coulour (1.e. autre que bloue ou noire)

Coloured plates and/or lllustrations/

Pianches et/ou illustrations en coulour

Bound with other matorial/

Polle avec d'eutres documents

Tight binding mar cause shadows or diatortion along interior margin/

La rellure earrie pout ceuser de l'ombre ou de la distortion le long de la marge intbrisure

Blank leaves added during rectoration may appear within the text. Whonover posalble, these hove been omittod from filming/

II 20 pout que cortaines pages blenches ajoutces lors d'une resteuration epperalseent dane lo toxte. mals, lorsque cels stait possiblo. cee pages n'ont pas oté filmbes.

\section{Additional commente:/}

Commentaires supplómentalres:
L'Institut a microfilm lo molliour exemplaire qu'il lul a tits posalble de se procurer. Les dotails de cot exemplaire qui sont pout-otre uniques du point de viv bibliographique, qui peuvent modifier une image reproduite, ou qui peuvent exiger une modification dans la mothode normale de filmage sont indiquís ci-dessous.

Coloured pages/

Pages de coulour

Pages damaged/

Pages endommagles

Pages reatored and/or Iaminated/

Poges restaurces ot/ou polliculbes

Pages discoloured, stainad or foxed/

Pages dicolorbes, tachetbes ou piquebes

Pages doteclied/

Pages d'techies

Showthrough/

Traneperence

Quallity of print variod

Quallits incoale de l'impresaion

Includes supplomentary matorial/

Comprend du matoriel supplómentaire

Only edition ovallable/

Seule edition disponible

Pages wholly or partially obscurad by errate ellipa, tiesuce, otc., have been refilimed to ensure the beot posalble image/ Les pages totaloment ou partiallement obecurcies per un feulliet d'orrate, une pelure. ote.. ont sté filmbes a nouveau de facon obtenir la mollleure image poadble.

This item is fllmad ot the reduction ratio checked below/ Ce document eat fllimb au taux de reduction indiqub el-deseous.

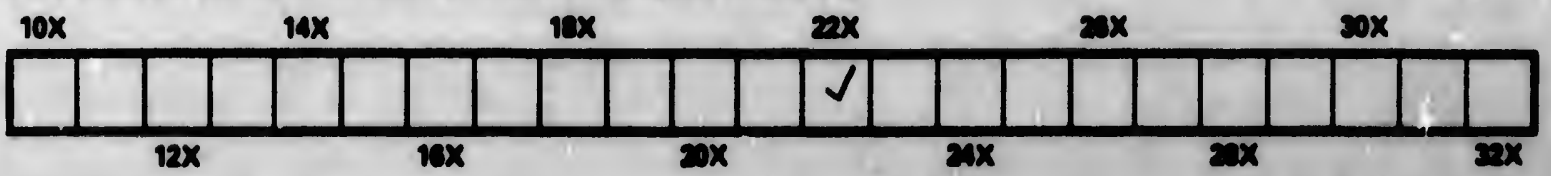


The copy filmed here has been reproduced thenks to the genorosity of:

\section{Lubrary \\ Apriculture Caneda}

The Images appearing here are the best quality poselble consldering the condition and loglbillty of the original copy and in keoping with the filming contract spoclifleationa.

Original coples in printed paper covere ore filmed berinning with the front cover and ending on the last page with a printed or lllustrated imprese sion, or tho back cover when appropriate. All other orfolnal coples are filmed beginning on the first page with a printed or llluotroted impres. elon, and ending on the leot page with a printed or lllustrated impreseion.

The last recorded freme on each mlerofiche shall contain the symbel $\rightarrow$ imcaning "CONTINUED"), or the aymbol $\nabla$ (meaning "END"). whichever appllec.

Maps, plotes, charts, cte., moy be fillmed ot different reduction ratios. These too large to be entirely included in ens expecure ore filmed beginning in the uppoer bit hend comver, bft to ilaht and top to bottom. co mamy fremes es required. The following dlegrems Illustrote the mothod:

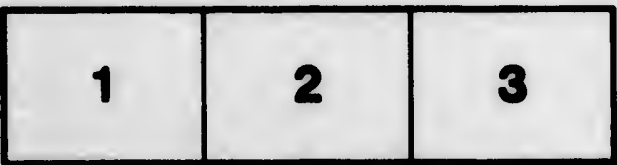

L'exemplaire films fut reprodult grace it is ónoroolto do:

Bibliothique

Agriculture Caneda

Les images sulvantes ont lit reprodultes avec lo plese grand soin, compte tenu de fa condition ot de lo nottot's de l'oxemplaire filmb, ot on conformits avec les conditions du contrat da filmoge.

Les exemplaires origlnaux dont is couverture en papier cot Imprimce sont filmce en commencant par le promior plat ot en torminant solt par la dernibre page qul comporte uns emprelnte d'impreselon ou d'illustration, solt par lo second olar, eolon b cas. Tous les autres exemplalres originaux sont flimbs en commengant par la premilere page qui comporte uns emprointe d'impreselon ou d'lllustration ot en terminent par la dernithe page qul comporte une tolle empreinte.

Un des oymboles sulvants apparaitra sur la dernibre image de chaque microficho, selon le cas: lo symbole $\longrightarrow$ dioniflo "A sUIVRE", lo symbole $\nabla$ signifilo "FIN".

Les cartes. plenches, tableaux, etc.. pouvent otre filmbe des toux de reduction diffírents. Lorsque is decument cet trop grand pour fetre reprodult on un eoul ollohs. II cot filmo \& partir do lengle supdribur gaveho, de gauche a droite. at do haut en bea, en pronant is nombre d'imeges nesecsaire. Les dlagrammes sulvants Illuotrent la mothods.

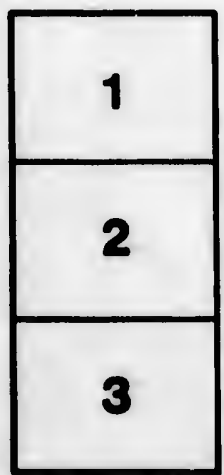

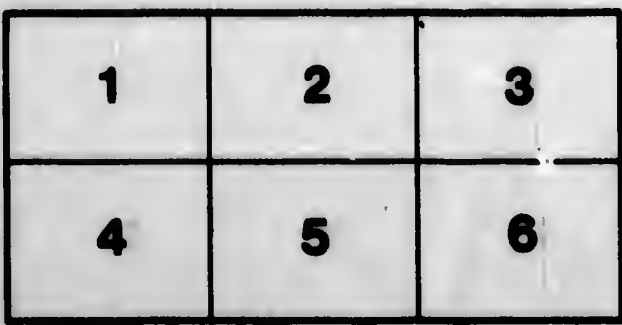




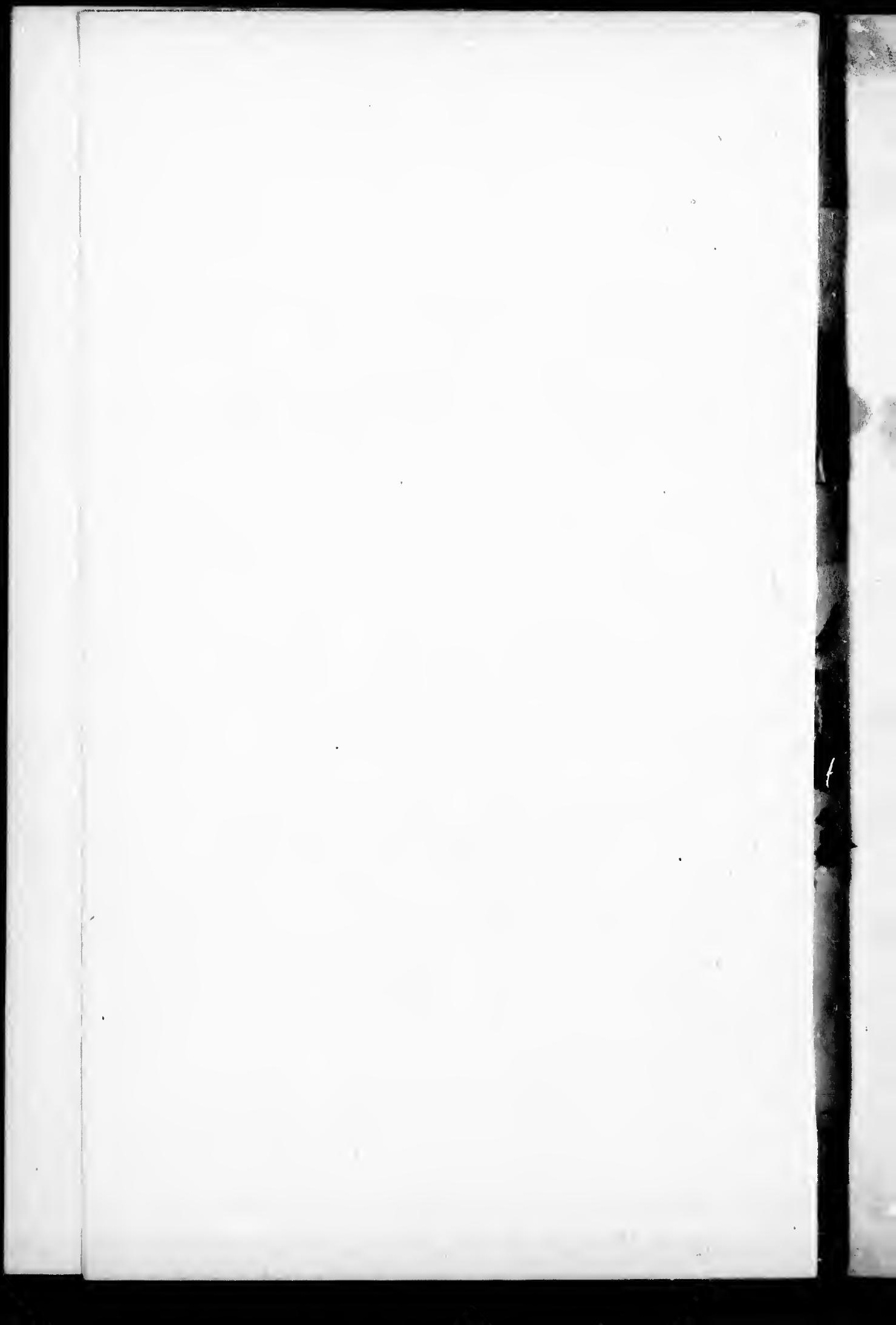




\section{SMITHSONIAN INSTITUTION.}

UNITED STATES NATIONAL MUSEUM.

\section{$4 / 43$}

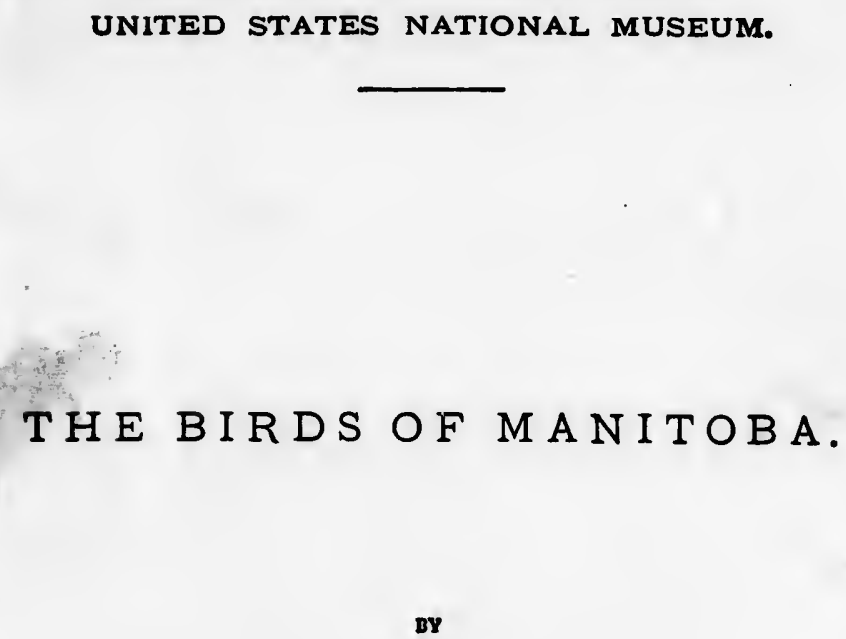

ERNEST E. THOMPSON, of Toronto, Canada, Associate Momber Amerian Ornithologists' Union, ate. From the Proceedings of the United States National Museum, Vol. XIII, pagree 4sp-4hs
with plate XXXVIII.

[No. 84t.]

WASHINGTON,

COVLKNMENT PRINTINe OMmCL.

1891.' 


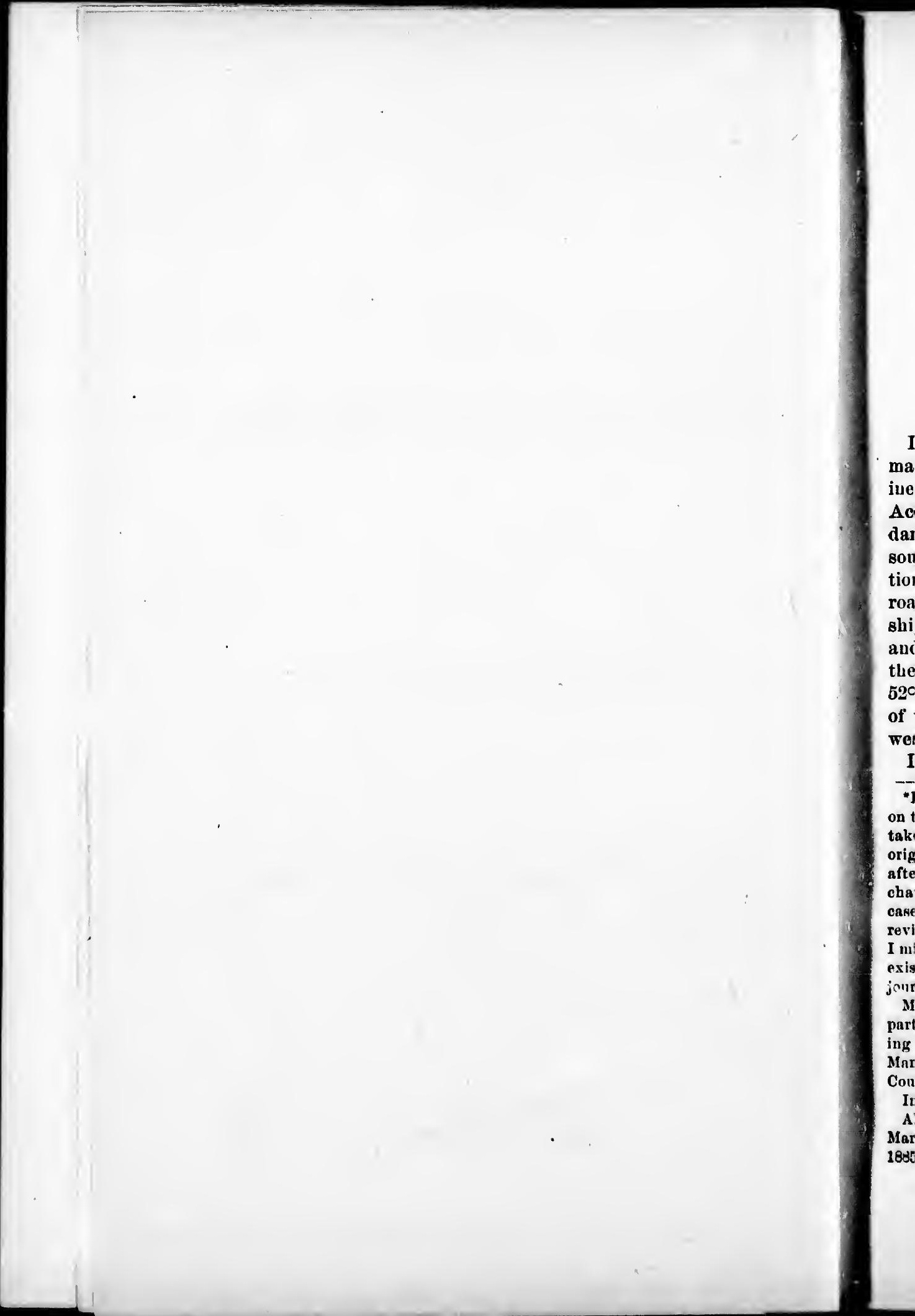




\title{
THE BIRDS OF MANITOBA.*
}

\author{
BY \\ Ernest E. Thompson, of Toronto, Canada, \\ Associate Member American Ornithologists' Union, etc.
}

(With plate xxxvir.)

INTRODUCTION.

BOUNDARIES OF THE PROVINOR OF MANTTOBA.

In treating of the birds of this region it seemed most convenient to make the political boundaries of the province, those also of the district included, though this is scarcely defensible from the scientific standpoint. According to the Revised Statutes of Canada, 1886, chapter 47, the boundaries of the province of Manitoba were fixed briefly as follows: On the south, at the forty-nin th parallel of north latitude, which is the interna. tional boundary line; on the west by a line along the middle of the road allowance between the twenty-vinth and thirtieth ranges of townships west of the first priucipal meridian, which line falls between $101{ }^{\circ}$ aud $102 \circ$ longitude west of Greenwich; on the north by the middle of the road allowance of the twelfth base line, which is north latitude $52{ }^{\circ} \mathrm{50}^{\prime}$; on the east by the meridian of the northwest angle of the Lake of the Woods which, according to Professor Hind is $95^{\circ} 50^{t}$ longitude west of Greenwich.

In preparing my own map full use has been made of the maps pub-

"In offering the following observations in their present ehape, i. e., ae they were made on the epot, without material condenestion or generalization, I believe that I have taken not merely the best but the only right course nnder the oiroumstances. My original plan, as mas be seen by the "notes" thronghout, was to prepare something after a very oid-fashioned model, but widening experience cansed a considerable change of view. No one regrete more than myelf their imperfectness, and, in eome cases which I have pointed out, their unreliability. If I conld revisit Manitoba in the near future I would gladly defer publioation in the hope that I might first remove numerous doubts and fill many unfortunato blanke, but under existing circumetances there scems to be no conree but to oarefuliy revise my old jenrnal and let it go forth for judgment.

My own observations are supplemented by those of numerous observers in varions parts of the province, and I lave also endenvored to include all available recorde relating to distribntion and all valuabie published matter relating to the ornithology of Manitoba that has not appeared in a special work on birds. This excludes only Dr. Conee's field notes " * forty-nintli parallel, which, however, is constantly oited.

In all the recoris I have given the exact worde of the writer aro quoted.

Altogether I spent about 3 years in the province, my first visit extending from Maroh 28, 1882, to November 16, 1383; my second from April 25, 1884, to January 27 , 1885; my third from Ootober 25, 1886, to Jannary 12,1887 , brokeu only by occasioual 
lished by Professor Hind in 1860, by the Dominion Government in 1874, and by the Uanadian Pacific Railway Oompany at various times between 1880 and 1890, also those drawn by Mr. Shawe for Phillip's Imperial Atlas, and those issued by the Tenth Census Report of the United States. I have also supplemented these by information gainect in my own travels, as well as that supplied me by Messrs. Tyrrell, Nash, Maconn, Christy, and other observers.

\section{PHysical Features OF THE PROVINOE.}

The general features of the country have been ably and concisely described by Dr. Dawson in the report of the boundary commission (1875), as follows :

The first or lowest prairie level, is that of which the southern part lies along the Red River, and which, northward, ombraces Lake Winnipeg and associsted lakes, and the flat land surronnding them. A great part of its eastern bordor is conterminous with that of Lake Winnipeg, and formed by the rooky front of the Laurentian; but east of the Red River it is bounded by the high lying drift terraces surronnding the Lake of the Woods, and forming a part of the drift platesu of northern Minnesota. To the west it is limited by the more or less abrupt edge of the second prairie levei, forming an escarpment, which, though very regular in some places, has been broken timrough by the broad valleyn of the Assiniboine and other rivers. The escarpment, where it prosses the line, is known as Pembina Monntain, and is continued norshward by the Riding, Duck, Porcnpine, and Basquia Hills. The average height above the sea of this lowest level of the interior conti-

expeditions ontside of onr boundaries. Carberry was my headquarters, and except where otherwise stated all observations were made at that place.

My companions, whose names appear, were Mr. Wm. G. A. Brodie, whose untimely death by drowning iu the Assiniboine, May, 1883, robbed Canada of one of her most promising young natnralists; my brother, Dr. A. S. Thompson, with whom I lived, and Mr. Miller Christy. The last was with me during the latter part of the summer of 1883 and again for a few days in the July of 1884 . He was the first ornithoiogist of experience that I had-ever met, and I have to thank him for correcting in me many wrong methods of study that naturally were born of my isolation.

My thanke are due to Dr. J. A. Allen, of the American Mnsenn of Natnral Hiatory ; Prof. Robert Ridgway, of the Smitheonian Institution; and Dr. C. Hart Merrian, ornithologiat to the U. S. Department of Agriouiture, for the identiflcation of numer. ous apecimens, and other assistance, and especially to the last for plaoing at my disposal the manuscripts of Miss Yoemans, Messrs. Calcutt, Criddle, Nash, Plankett, Small, and Wagner; to Prof. John Macoun, of the Canadian Geological Survey; Messrs. Christy, Nash, Hine, Hunter, and Guernsey, for numerous manuecripte, notes, and much valuable a sistance; to Dr. R. Bell aud Mr. James M. Maconn, both of the Canadian Geological Survey; Dr. William Brodie, of Toronto; Dr. Charles Carpmael, of the Canada Meteorological Department, and Mr. Ernest D. Wentle, of Montreal, for belp in varions waye; and to the Hudson's Bay Company for access to the Hutchins mannscripts. Indispensable assistance in preparing the manuecript has been rendered also by my father, Mr. Joseph L. Thompson, and my cousin, Miss M. A. Burfield.

The messurements thronghout are in English inohes.

Ernest E Thompron, 86 Howard otreot, Toronto, Ontario.

JULY, 1890. 
nment in 1874, ious times beor Phillip's Im. Report of the mation gained Tyrrell, Nash,

\section{and concisely} iry commission

lies along the Red ociated lakes, and bordor is concky front of the high lying drift art of the drift ore or lese abrupt ough very regular be Assiniboine and lown as Pembina upine, and Basquia he interior conti-

arters, and except

e, whose untimely of one of her most ith whom I lived, art of the summer rst ornithologist of boting in me many

Natural History; C. Hart Merriain, ification of numerplacing at my diso, Nash, Plnukett. feological Surrey; rons manuscripts, s M. Maconn, both onto; Dr. Charles rest D. Wentle, of upany for access to gg the manusoript ad my cousin, Miss

Thompsos, Toronto, Ontario. nental region is about 800 feet; the lowest part being that surrounding the Winnipeg group of lakes, which have an elevation of abont 700 feet. From this it slopes up sonthward, and attains its greatest elevation-960 feet-at ite termination far south in Minnesota. The edges of this prairie level are also, notwithstanding its apparent horizontailty, conslderably more elevated than its central line, whicb is followed by the Red River. Ite width on the forty-ninth parallel is only 52 miles; its area, north of that line, may be estimated at 55,600 aquare milee, of which the great eystem of lakes in ity northera part-including Lakes Winnipeg, Manitoba, Winnipegosis, Cedar, and St. Martln's-occnpy 13,900 milee. A great part of this prairie level is wooded more or less densely, and mach of the low-lying land near the great lakes appears to be owampy and liable to flood. Tho oonthern part, extending from the bouudary line nearly to the sonth end of Lake Winnipeg, includes the prairie of the Red River valley, with an area of about 6,900 equare uniles; one of the most fertile regions, and, at the eame time, the most avcessible portion of the Northwest.

The superficial deposits of this stage are chiefly those of a great lake which occhpied its area after the giacial eubmergence. This part of the interior of the contlnent being the last to emerge from the Arctic waters and having beeu covered for a long time afterwarl by a sea of fresh water, held back either by drift deposits or by rocky harriers, which have subsequently been ont throngh, and which must have united all the lakes now found in the region into one sheet of water, which extended with narrower dimensions abont 200 miles south of the bonndary line.

The Red and the Aseiniboine Rivers and their tributaries have not yet cut very deeply into its alluvial deposits and its surface is level and little furrowed by denu. lation.

The second steppe of the plains is bounded to the east, as already indicated, and to the west by the Missouri coteau, or edge of the third prairie level. It has a width at the forty-ninth parallel of, probably, 200 miles, thongh it cau not there be strictly defined. Its total area is about 105,000 square miles, and includes the whole eastern portion of the great plains, properly $B 0$ called, with an approximate area of 71,300 square miles. These'occnpy its southern and western portions, and are continuous westward with those of the third prairie steppe. To the south, the boundaries of this region appear to become more indefinite, and in the southern part of Dakota, the three primary levels of the conntry, so well marked north of the line, are probably scarcely separable. The rivers have acted on this region for a much longer time than on the last-mentioned, and are now found flowing with uniform currents in wide ditch-like valleyo, excavated in the soft material of the plains, and often depressed from 100 to 300 feet below the general surface. In these the comparatively insignificent streams wander from side to side, in tortaous channels, which they onl. leave in time of flood. The enrface of this prairie steppe is also more diversified than the last, being broken into gentle swelle and undulations, partly, no doubt, by the action of deondation, and partly, also, as will appear, from the oxiginal nnequal deposition, by carrents and ice, of the drift material which here constitntes the enperficial formation. The average altitude of this region may be taken at 1,600 feet, and the character of ito soil and its adaptability for agriculture differ unoh in its different portions.

The third or highest prairie steppe may be eaid to have a general normal aititude of about 3,000 feet, though its eneteru edge is oometimes little over 2,000 feet and it attains an elevation of 4,200 feet at the foot of the Rooky Mountains.

Obviously none of the third steppe would fall within our limits were it not for a curions exception that is presented by the Turtle Mountain, which, though belonging to the third steppe, stands like an island upou the open sea of the second. Of this Dr. Dawson says :

Turtle Mountain, an ontline of the third prairie steppe, is a broken, hilly, wooded region, with an area of perhaps about 20 miles square (400 square miles), and slopes 
gradually upward from the plain around it, above which it is elevated, at its highest points, about 500 feet. It appears to be the oulmisation westward of the hilly drift region previonsly described, and forıns a prominent object when viewed across the eastern prairie, from the contrasting somber tint of the foliage of its woods. Frcm the west it oan be seen from a distance of 45 miles, and when thus viewed has really mnch the general outline of a turtle shell. It is bisected by the forty-ninth parallel.

According to Mr. Tyrrell's map, the altitudes of the large lakes, etc., to the west have hitherto been given fully 60 feet too low; as, how. ever, I am without corrected figures for other points whose altitudes are given, I have elected to let older computations stand, and they may be taken as relatively correct.

"The sandhills," so often referred to, are certain low sand dunes that cover a cousiderable extent of count ry in the vicinity of Carberry. They are in most cases $10 \mathrm{~W}$ undulations rather than hills, are sparsely covered with grass and dotted over with beautiful clumps of trees, while the hollows and flats are diversified with lakelets that swarm with waterfowl and lower forms of life. The general appearance of the sanclbills country is quite park-like, and notwithstandiug its unattractive nalue this region as a whole is the most pleasing to the eye and fuller of interest and varied pleasure for the naturalist than any other that I have seen in Ma nitolia. "The Big Plain" is an unusually level prairie extending from Carberry north ward about 30 miles.

"The White Horse Plains" form a similar region between Shoal Lake and the Assiniboine.

"The Souris Plains" include the south western corner of Manitoba that is drained by the Souris River. This is a remarkably level region, en. tirely cleared of trees excepting in the river gorges, and diversified by numerous marshes and alkaline flats.

"Bluff" is, in Manitoban parlance, the uame applied to any isolated grove of trees on the prairie. The term is never used here, as in the Western States, to mean an abrupt bank or escarpment.

Distribution of forest and prairie.-All that portion of Manitoba that lies to the eastward of the lowest prairie steppe, as above defined, is a rocky Laurentian region full of rivers and lakes of fresh water, and thickly wooded, being within the limits of the great coniterons forest. A wide strip of the flat country lying to the westward of Lake Winni. peg, likewise the elevat d plateaus of Riding, Duck, and Porcupine Mountains, are also to be classed as parts of the northern forest. There is good reason for believing that at one time, not very remote, the rest of Manitoba was covered with a forest of aspens or popla is (Populus tremuliodes), slightly varied by oak (Quercus macrocarpa), spruce (Abies alba et nigra), birch (Betula papyracea), etc., which has been removed hy fire, so that trees are now found growing only in such places as are protected from the fires by streams, lakes, marshes, or' sandy tracts where so little grass grows that the fire can not travel; consequently, notwith. standing the prevalent idea of Manitoba as a purely prairie region, there is more or less timber in uearly all parts of the country as indicated on waters.

They 0 of salt-be surface orer the waters" swarming and aqua sand hills several p tain kind: Sparrow,

Salt $\boldsymbol{s p}$

well-knor

prove an

Lying fas the western known to $b$ Numerone er the wr various $10 \mathrm{c}$ springs kno interest in

1. Crane

2. Water

3. Salt $P$

4. Sait $S_{\text {] }}$

5. Plne $\mathbf{R}$

6. Rivers 
at its highest he hilly drift d across the roods. From red has really inth parallel.

lakes, etc., $\pi ;$ as, how. ltitudes are ley may be

dunes that Carberry. re sparsely of trees, swarm with of the sanclnattractive ind fuller of ther that I evel prairic

Shoal Lake

nitoba that region, enrersifled by

ny isolated e, as in the

nitoba that lefined, is a water, and rous forest. ake WinniPorcupine est. There te, the rest s (Populus ruce (Abies emoved by as are proacts where $\nabla$, notwith. gion, there dicated on the map. Thus I have endeavored to raake a record of the distribution of forests in 1885, for evidently no natural feature is more likely to change in a few sears than the extent of woodlands. The line limiting the coniferous forest ou the south is copied from the forestry map issued with the Tenth Census report of the United States. It is suspiciously straight and eren, but is doubtless correct when understood merely as a broad generalization. I regret that I am without the material necessary to define this limit more accurately. To the sonthward of Carberry is a small isolated forest of spruce that is knowu as the Spruce Bush or the Carberry Swamp, by which names it is herein referred to.

Water.-The province is plentifully, almost too plentifully, supplied with water. In addition to the numerous extensive lakes indicated on the map are thousands more of smaller extent, while the region of the Red River Valley in particular is diversified by vast stretches of marsh and lagoon. The various lakes are of two kinds, first the sweet water or live water lakes, fed and drained by living streams, teeming with fish and varying in size from that of a mere pond to that of Lake Winnepeg; second, the alkaline lakes, which are mere drainage basins and depend solely on evaporation for the removal of their accumnlated waters.

They owe their alkaline impregaation not to anything of the nature of salt-bearing strata, but to the continual influx and evaporation of surface water rery slightly impregnated with alkali through running over the prairies strewn with the ashes of the annual fires. These "deal waters" never, so far as I know, contain fish, but they are usually swarming with a species of amblystoma and uumerous kinds of leeches and aquatic insects. These lakes abound on the prairies and in the sand bills, but are usually of very small extent. They hare, I beliere, several peculiar species of sedge, and are especially frequented by certain kinds of birls that seem to avoid the fresher waters, e. g., Baird's Sparrow, Avocet, etc.

Salt springs, etc.-The following extract from Professor Macoun's well-knowu work on " Manitoba and the great Northwest, 1883," will prove an interesting item of physiography:

Lying farther south [than the Silurian], and possibly underiying the greater part of the western side of the Manitoba Plain, is the Devonian Series. These rocks are known to be largely doveloped on both sides of Lakes Manitoba and Winnepegosis. Numerons ealt eprings are found in connection with them, and daring the last sum- er the writer saw sait eprings and brooks of strong brine flowing from them in various localities at the head of Lake Winnepegosis. The eubjoined list of ealt springe known to ocear on Lakes Manitoba and Winnepegosis may tend to excite interest in these extensive deposits:

1. Crane River, Lake Manitoba.

2. Waterhen River, Diokson's Landing.

3. Sait Point, east side of Lake Winnepegosis.

4. Salt Springs, Winnepegosis.

5. Pine River, Winnepegoeis.

6. Rivers near Duck Bay. 
7. Turtle River, Lake Dauphin.

ช. Swan or Shoal, two locallties.

9. Salt River, flowing into Dawson's Bay.

10. Numerous salt springs and bare, saturated tracte of many acres in extent on Red Deer River, which flows into the head ct Dawson's Bay, Lake Winnopegosit. For 10 miles up this river salt eprings are quite frequent, and excellent salt was collected in three places, where it formed a crust on the surface of the ground. Some springs were examined where a respectable rivulet of strong brine issued from then, as clear as crystal, and evidently quite pure. All the oprings and marshes oeen were bordered with seaside plante, and one of them, which has never been found from the seaconst before in Auerica, was found in abnudance. The plant referred to is SeaSide Plautain (Plantago maritima).

The following extract from Professor Hind's report (1858) shows that this line of saliferous strata goes right across our province:

Near and west of Stony Mountain many amall barren areas occur, covered with ealine efflorescence; they may be traced to the Assiniboine, and beyond that river in a direction nearly due south to La Riviere Sale and the forty-nintb parallel. These ealine deposits are important, as they in all probsbility serve, as will be shown hereafter, to denote the presence of salt-bearing rocks beneath them, similar to those from which the salt springe of Swan River, Manitoba Lake, and La Riviore Sale íssue.

Meteorology.-I have not been able to obtain the material necessary for a generul chapter on the meteorology of Manitoba, and must con. tent myself with a few statistics taken from Professor Bryce's article on Canada in the Eucjelopædia Britannica.

The mean annual temperature for 11 years, (1871-1881, inclusive), taken near Winnipeg, was $33.06^{\circ}$, the maximum $95.34^{\circ}$, the minimum $-10.51^{\circ}$; the mean amount of rain, 16977 inches; the mean amount of sllow, 52.72 inches; the mean total precipitation of rain and snow, 23.304 inches; the mean height of the barometer, 29.153. The mean arerage temp eiature for the years 1880 and 1881 was as follows: Jan. uary, $2 \circ .9$; February, 3०; March, $9 \circ$; April, 30॰.2 ; May, 51०.2 ; June, $63^{\circ} .6$; July, 65०.9; August, 640.8; September, 510.3; October, $40^{\circ}$; Norember, 140.6; December, 00.6; the year, $32 \circ .6$.

The isotherms indicated on the map were taken from the map pre. pared to Professor Macouns' work.

Topography.-The topography of Manitoba is somewhat perplexing through the duplication of names. Many, such as Pelican Lake, Swan Lake, Shoal Lake, Rat Creèk, etc., appear several times over. None of these duplications have been entered on the map, with the excep. tions of Shoal Lake and Boggy Creek. In the first case I have added the word "West" to the name of the lake which is of secondary im. portance and probably of later naming. In the second the three creeks are distinguished as Boggy Creek, Big Boggy Creek, and Little Boggy Creek. Every name referred to in the notes, with exceptions noted lierein later, will be found on the maln, with many additional ones that are of importance. Frequent allusion is made to Frofessor Maconns' jour. noys and the regiou observed by him in making them. These expedi-

tions we thence $\mathrm{t}$ les, now 1881, fro Totogon Waterhe pegosis, np Swan Deer Ri to Livin

Hump

Markle's $\mathrm{Hill}, \mathrm{Ke}$ berry. for the o

The fo

to extens

Carlet:

Cumbe

Fort $P$

Fort $Q$

tion witb

Moose

latitude

Nelson

Norwa

Rat Pc

Canadiar

Red D

ner of th

Severn

$30^{\prime}$ west

Selkir'k dary.

Touch

Trout

$91{ }^{\circ}$ west

White

northwes!

Tolerat wards the Lake Ma1 dent alon 
tious were as follows : $18 i 9$, from Winnipeg to Fort Ellice by water and thence up the Qu'Appelle River; 1880, from Winnipeg to Grand Val. ley, now Brandon, by water and thence overland to Moose Mountain; 1881, from Winnipeg to Portage la Prairie by rail, thence overland to Totogon down Lake Manitoba by boat into Waterhen River and into Waterheu Lake, and back by the western channel into Lake Winuepegosis, and along the western shore of this lake into the larger bays, np Swan River to Swan Lake, then back to Winnepegosis and up Red Deer River to Red Deer Lake, up its southern affluent across country to Livingstone and down the Assiniboine to the railroad at Brandon.

Humplrey's or McGee's Lake, Hope's Lake, Smith's Lake, and Markle's Lake are small drainage lakes near Carberry. White Horse Hill, Kennedy's Plain, and De Winton Slough are alsu close to Carberry. These have been omitted from the map, as they are too small for the scale on which it is drawn.

The following places outsicle of the province have been mentioned to to extend or explain the distribution of certain species :

Carleton House: On the north branch of the Saskatchewan.

Cumberland House: On the Lower Saskatchewan.

Fort Pelly: On Assiniboine River, 10 miles west of Duck Mountain.

Fort Qu'Appelle: Ou Qu'Appelle River, 100 miles up from its junc. tion with the Assiniboine.

Moose Mountain : Assiniboia, 35 miles westward of Manitoba, about latitude $49^{\circ} \mathbf{4 0}$ ' north.

Nelson River: The outlet of Lake Winnipeg, situated at its north end. Norway House: North end of Lake Winnipeg.

Rat Portage: On the Lake of the Woods, where it is touched by the Canadian Pacific Railway.

Red Deer River: Flowing into Red Deer Lake, at the northwest cor. ner of the province.

Severn House: On Severn Lake, at $54^{\circ} 5^{\prime}$ north latitude and $92^{\circ}$ $30^{\prime}$ west longitude, about 150 miles northeastward of the province.

Selkirk : Lake Winnipeg, about 40 miles north of the northern boun. dary.

Touchwood Hills : 30 wiles north-northwest of Fort Qu'Appelle.

Trout Lake House: On Trout Lake, at $53^{\circ} 50^{\prime}$ north latitude and $91 \circ$ west longitude, about 200 miles northeast by ebist of the province.

White Sand River: A tributary of the Upper Assiniboine, near the northwest corner of the province.

\section{Echmophorus ocoldentalis. Western Grebe.}

Tolerably common summer resident in Red River Valley, chlefly towards the northward, as follows: Quite common at Shoal Lake, near Lake Manitoba, and less so at Redburn (Hine). A rare summer resident along Red River (Hunter). Breeding in vast numbers at Shoal 
Lake and Lake Manitoba, not elsewhere (D. Gnnn). "Clark's Grebe," Shoal Lake (Brewer). Breeding on Lake Manitoba and very abundantly in the marshes of Waterhen River, between it and Lake Winne. pegosis. I took great numbers of eggs on Waterhen River and the south end of Waterhen Lake (Macoun).

I did not meet with this bird in any part of western or sonthern Manitoba, but at Winnipeg I was shown several speoimens taken near Kedburn, where it is somewhat common, and others from Shoal Iake, where it is quite plentiful. These facts, together with the following statement by Professor Macoun, are the more interesting when we coul. eider that for a long time this grebe has been considered a bird of the Pacifio region.

In his work on the Northwest, Professor Maconn writes:

On Waterhen River and Lake the Western and Red-necked Grebes breed in great numbers. Their nests are built on the old sedges and rise and fall with the water. Here the Indians collect large numbers of eggs in the proper season, and one old fellow, last season, sstonished me by the remark that he conld bave fresh egge all summer. Ou Inquiry I learned that he went regularly to the same neste and never took all the eggs 80 that he kept the poor bird laying all sumn er.

Mr. D. Gumn makes the following remarks on this species at the lake in question:

The annual resort of the Podiccps occidentalis to Shoal Lske is, as has been observed, "remarkable." Froun the most reliable information that I could obtain from the Indians at this place it has never beeu seen on the Rell River nor on ou Lake Winuipeg, and I have never hearl of its haviog been seen nnywhere in what is eommonly known as Rnpert's Lani, except at Shoal Lake and Manitoba, and I muy ald that it is also remarkable that there are very few grebes to be found in any other of the bays connected with the lake, althongb all these bays abound in reeds ancl rushes. Possibly these birds prefer the bay on the north point on neconnt of its being sheltered from the wind, and probably a greater facllity for obtainitg food in that loeallty inny infuence them in the ohoice they make. I nm luclined to think that the large grebes feed on aquatio plnuts; I opened several of their gizzarda and found nothing in them but grass. The Western Grebes, when seen in groups on the smooth, unruffled waters of the lake, make a splendid appearance, sometlmes raising thenselves ont of the water, and flapping their wings, Cheir white breasts gllstening in the sun like silver. They are not timorons, but when alarwed they sluk their bodies in the water, and if the object of their foar still presents itself they plunge beal foremost ancl dive anul continue a long time under the water, often disapjointing the expectations of their pursuers by reappearing in a difierent direction from that nuticipated. They make their nests anong the reeds on the bent bulrushes of tho last season; the framo or outer work is of reeds and lined with grass from the hottom and reed leaves. The nest ls nearly on a level with the snrronndiı g water nnd mny be ald to llont at Its "monrings," held there by the reeds. Wo found humireds of these nests contain. ing two, three, und four egge ench; I believe six to be the highest number we fouml in any one. We tonk thirteon grebeg, of whieh the males were latger than the fo. males, the largest male measured, before skinning, $27 t$ by $36 t$ inches ani 14 inches round the boly nt the heal of the wings. The lnrgeat fomale measured $24+$ ly 32 f inches. Wo shot not $\mathrm{a}$ few of them in the act of leaving their neate, and wost of them on bei: g skinneil proved to be nales, which fact inclines mo to belleve that the male bird takes bis turn in aitting on the egge. 
rk's Grebe," very abun. Lake Winne. iver and the

or sonthern o taken near Shoal Iuake, ho following vhen wecou. bird of the

breed in great rith the water. and one old fel. ih egge all sum. and never took

38 at the lake

been observeil, in from the IIIako Winuipey, mmonly known 1 that it is also f tho bays conrnshes. Possibeing shelterel at locality may that the large found nothing mooth, unrufing themselves ing in the sun ir bodies in the head foremost ng the expesta. at anticipated. ast season; the and reed leaves. arid to flont at b nests contain. inber we found for than the fo. and 14 inches hrod 24 t by 32 t nel most of tbem e that the molo
2. Colymbus holbcollii. Holboll's Grebe. Red-neoked Grebe.

Summer resident chiefly of the shallow, fish-frequented lakes to the northward. Winnipeg: Summer resident; very rare; only 4 specimens taken up to 1885 (Hiue). Breeding in considerable numbers at Shoal Lake; comparatively rare in Red River region (D. Gunn). Specimen from Red River settleinent in Smithsonian Institutiou (Blakiston). Breeds abundantly in the marshes of Waterhen River and south end of Waterhen Lake, where I took great numbers of its eggs (Macoun). Duck Mountain; breeding (Thompson).

On June 18, 1884, while hunting at Duck Mountain, above Boggy Oreel, with my brother, we came to a small lake and parted to go around it in different directions. When we met, he showed me a nest which he had found among the reeds in 2 feet of water. It was a mere floating mass of wet rushes, and had been moored by a fow growing rushes whose tops had been incorporated with the structure. It con. tained $3 \mathrm{eggs}$, which the birl was hastily covering with more rushes when he frst saw her. From his deseription, and from what I could see at 200 yards distance, it was apparently an adult Red-necked Grebe, but the bird was too shy to admit of the identification being completed in the only perfectly reliable way.

As there are no fish in these isolated mountain lakes, these birds probably live largely on amblystoma, crawtish, and insects.

\section{Colymbus auritus. Horned Grebe.}

Abundant snmmer resident of general distribution; very abundant; breeding at Peinbina and the base of the Turtle Mountain (Ooues). Luke Winnipeg (Murray). Red River (Kennicott). Common summer resident in Red River Valley (Hunter). Common about Winnipeg (Hine). Very common on Red River, and breed in the marshes near Shoal Lako (Gunu). Portage la Prairie; common summer resident (Nash). Ob. served in the ponds from Turtle Monntain to Brandon, in May, 1882; commonly breeding in all the ponds about the Big Plnin, being the most abundant Grobe of the region; common also from Carberry to Ripid Oity and thence west to Fort Ellice, and in the whole region on both sides of the Assiniboine, north ward to Duck Mountain (Thompson). Abundant on Waterhen River; breeding; they give the name to the river; the common Grebe of the prairie ponds (Miconiu). Shell liver; 1885, first seen, two on May 3; afterwarls seen every day; it í common all summer ancl breeds here (Calcutt). Tront Lake (Murray).

On July 20, 1883, in a lake nenr "The Gore," shot a Horued Grebe. It had saved itself once or twice by diving at the puff of smoke, so I cought the cover of the busbes and fired throngh an opening, and as uo amoke was visible I got the birl. It was au alult male; length, 14 inches, extent 24 inches; monlting ; iris blood red, with an inner oircle of white around it; basal region and part of lower mundible mijoining Pruc. N. M. $90 \longrightarrow 30$ 
covered with bare red skin ; in examining the eye, I squeezed out a leech, that was sometimes like a No. 4 shot or again like a small needle.

On June 3, 1884, while traveling on the Birtle trail from Rapid City I uoticed a pair of Horned Grebes in a small pond. I firerl and disabled one. On wading in I found it was shot in the eye and was perfectly blind, though otherwise unhurt. Having beard sundry curious theories about the way in which these birds move their feet, I kept it alive for observation. When ordinarily swimming the feet strike out alter. nately, and the progression is steady, but somecimes both feet struck together, and then the movement was by great bounds and was evi. dently much better calculated to force the bird over an expanse of rery weedy water or through any tangle of weels or rushes in which it might have found itself. When lifted out of the water the feet worked so fast as to be lost to the eye in a mere haze of many shadowy feet with one attachment. When placed on the ground it wns perfectly helpless. At nights I luid it by my side on the grass, and each morn. ing I found it still in the same place. During the day I carried it in a bucket swung under the wagon. It often tried to leap out of this, but never sncceeded. On the second day of its captivity it laid an egg, which was like a cluck's egg with a heavy coat of whitewash. On the third day, after the wagen had crossed some rough ground, which had set the pail violently swinging, I found the grebe was gone. All the specimens of cornutus that I have examined have the eye all blood. red except a thin ring of white which immedintely surrounds the pupil.

On August 21, 1884, shot a Horned (8) Grebe in the lake southwest of here. Several young ones were seen. No donbt the species breeds there as in all the small drannage ponds in this region, although they are totally devold of fish. The only animal food available for the grebes in there is amblystoma, frogs, leeches, and insects.

Dishlshet Seekeep or Little Diver. This bird difiers but littlo from Mr. Pennant's omall grebe. It weigho 5 tounoes, harbors in our fresh waters, where it builds a floating nest of grass, laying from three to five eggs of a white color; the heat of the bird osusing a formentation in the grase, which ia a foot thlck, makes a kind of hotbed, for (please to observe) the water penotrates throngh the grass to the egge. (Hutchins's Observations on Hudeon Bay. MSS. 17\&2.)

\section{Colymbus nigrioolle oallfornious. American Kared Grebe.}

Common summer residout, breeding abundantly on Turtle Moun. tain and at points along Mouse River, near the bonudary (Ooues). Oommon summer resident in Ihed River Vulley (Hunter). Winnipeg: Summer resident tolerably common (Hine). Breeding in grent num. bers at Shonl Lake and on Red River (D. Gunn). Quite common on pools in prairie regions (Macoun). Very numerous in this buy (Grebe Bay, Shonl Lnke). They make their nests on the buirushes, composed of the sane material. We found as muny as six eggs in some nests, but in the greater number of nests ouly fonr. They are very shy and 
outa leech, needle. Rapid City nd disaloled as perfectly ous theories ; it alive for o out alter. feet struck nd was evianse of very in which it feet worked badowy feet ns perfectly each morn. arried it in a out of this, S it laid an tewash. On ound, which gone. All se all blood. ds the pupil. southwest of ecies breeds though they able for the

Mr. Pennant's ere it builds a the heat of the a kind of hotto to the egge.

robe.

urtle Moun. ary (Coues). Winnipeg: grent num. common on 5 biny (Grebe es, composed some nests, rery ahy and expert divers, are very common on the Red River, and breed in the marshes near the lake (D. Gunn).

5. Podilymbus podiceps. Pied-billed Grelee. Dabchick.

Common summer resident in all waters, living and dead; breeding at Pembina and on ponds at the base of the Turtle Mountain (Coues). Winnip'g: Summer resident; tolernbly common (Hine). Red River Valley : Summer resident; common; breeds at Shoal Lake (Hunter). Portage la Prairie; rery abundant; summer resident on every lake, slough, or pond large enough to give them sufficient "water privilege;" arriving as soon as the ice is out and departing wheu their haunts are frozen over. First seen, May 6, 1884, April 24, 1885, April 19, 1886 (Nash). Frequently observetl in the ponds from Turtle Mountain to Brandon ; in May, 1882, common and breeding in the ponds about Carberrs, also at Rapid City (Thompson). In immense numbers (killed four at a shot) in August and early part of September ou the beal waters and marshes of Swan River; abundaut on all pools south of Touch. wood Hills; apinarently more northern than the preceding (Macouu). Shell River, May 4 (Calcutt).

On June 30, 18:2, at Rnpid City, found a Pled-billed Grebe lying dead on the road. This species seems to be very abundant throughout the country from here to Carberry, anl from Carberry to Turtle Mountain, for the peculiar call note "pr-r.r.r.r tow tow tow tow" (that I asoribe to this species) is heard in nearly every warsh throughout the region indicated.

On Angust 12,1883, I came on a pair of Pied-billed Grebes in McGee's Jake, Carberry. Instead of diving they commenced flappiug over the surface and excited iny curiosity so that I shot them both. They were both Dabehichs, and I found they would not dive because the water was very weedy at that place. Their gizzards were full of water insects and feathers. These last are commonly found in gizzarls of Grebes. I know of no explauation of this fact, uuless it be to muffle the movements of newly swallowed living prey.

On September 13, 1884, at Portage la Prairie, found Dabchioks here yet. They seem moro numerous here than at Carberry.

\section{Orinator Imber. Loon. Big Heli.iver.}

Summer resilent on the larger fish frequented lakes. Summer resident; abundant, and breeding on Lake Wiunipeg and the larger rivers (Hine). Swampy Island : 1885, flrst seen, four, on May 30; next seen May 31; rare around this islnnd; not breeding here; common at northern end of lake in fall ; last seen September 27 ; in 1886, first seen, twenty, on May 14 (Plunkett). Onk Point : 1884, arrivell May 1 (Small). Portage la Prairie: Tolerably common on Lake Manitobn throughout the summer, nrriving with the first genoral thaw in spring and retiring when driven out by the frost (Nasl). Commou only on the northern 
lakes in the forest country; saw some on Red Deer Lake; never more than a pair together; never saw it in the prairie region (Macoun). Riding Mountain: June, 1884 (Thompson). Shell River: 1885, frst seen, a pair on May 4 ; afterwards, seen every day ; is common all sum. mer and breeds here (Calcutt). Qu A ppelle: Common summer resident, breeds; arrives April 23 (Guernsey). Severn House (Murray).

Athinne moqua, or Great Northern Diver. This elegant bird is seldom seen on the coacorats, but resides among the lakes above 100 miles to the sonthward of York Fort, for which reason they are called the inlend loons. (Hntchins's MSS. Observations on Hndson's Bay, 1782.)

7. Urinator arctions. Black-throated Loon.

Recorded by Andrew Murray, from Severn House, and therefore probably Manitoban.

\section{Urinator lummo. Red-throated Loon.}

Winnipeg: Rare (Hine). Norway House (Bell).

Assee moqua, or Red-throated Diver. " " " It appears in theoe parts when the rivers are open and retires about the end of September. Its note is harsh and disa- greesble, like equalling. They make no nest, only lining the place with a little down from the breast, on which they deposit their egge towards the end of June; they are of a stone color and only two in number. The young ones fly before the end of August. They live shiefly on fish and are excellent divers, and so very tronblesome to the nets that $I$ have this summer taken ont fourteen of them that were oaught in one tide at a eingle net. (Hutchine's Observations on Hudson's Bay, 1782.)

\section{Cepphus mandtil. Mandt'y Guillemot.}

Bevern House (Murray). This species may be named as probably Manitoban on the above grounds.

\section{Iarus argentatus smithsonianus. American Herring Gull.}

Summer resident abont the larger bodies of water; breeding in great numbers at Lake Winnipeg (D. Gunn). Specimen from Nelson River, in Smithsonian Institution (Blakiston). Oak Point : 1884, arrived April 21 ; 1885, first seen, two, on April 18; next seen, two, on 19th; is com. mon, and breeds here (Small). Breeding in all the large prairie lakes (Macoun). Portage la Prairie: Occurs during the spring and autumn migrations (Nash). Severn House (Murray).

The Island on which we were detained by a storal, is one of the Gull-egg groul, whlch, with a point of land protrnding from tho main land, fornis a pretty good harbor on the south side of the neck of the great promontory. The Indians were nearly deetitute of provisions and followed us to the Leland, where they fortunately got a plentiful supply of egge and young gulls; but haviug littlo ainmunition, they brought down only a fow olil ones, although they lovered in countless numbers over the island, seresming at the wholesale destrnction of their young brood. (IIurd, August 24, 1868.)

11. Iarus dolawarenute. Ring-billed Gull.

Summer resident, near Mouse River, on the boundary, in September (Ooues). Winnipeg : Summer resident, tolerably common, and at Lake

Oomm fish. W 
never more

n (Macoun). : 1885 , first non all sum. ser resident, ray).

om seen on the of York Fort, bservations on

ad therefore

iarts when the arsh and disa. h a little down June; they are re the end of ry tronblesome were caught in re2.)

as probably

Gull.

ing in great elson River, rrived April 9 th ; is com. rairie lakes and autumn

nll-egg grouj, etty good harore nearly desy got a plentithey bronght lobers over the Hurd, Auguat

September and at Lake
Winnipeg (Hine). North, in summer, to Lake Winnipeg (Brewer). Breeding in all the lakes of any size (Macoun).

\section{Tarus franklini. Franklin's Gull. Rosy Gull.}

Summer resident about the large lakes. Winnipeg : Summer resident; abundant; breeding in the prairie marshes of the neighborhood (Hine). Swamp Island: 1885, first seen, two, on May 28; next seen, May 29, after which it was common; it breeds here, and is an abundant summer resident; in fall, last seen September 25 ; 1886, first seen, six, on May 18; bulk arrived May 20 (Plunkett). Breeding at Selkirk Settlement, Red River Settlement, and in numbers at Swan Creek, Oak Point, Lake Manitoba (D. Gunu). Shoal Lake: May 15, 1887; common (Christy). Portage la Prairie: Common in spring migration ; in 1884, first seen April 21 (Nash). Breeding abundantly on Lake Winnepegosis, 1881 (Macoun). Carberry : A common spring migrant (Thompson). Turtle Mountain: Young (Coues). Shell River: 1885, "Black-Headed Gull," firstseen, two, on April 24; next seen, nine, on May 2 ; a transieut visitant passing north and not remaining any time or breeding (Calcntt).

\section{Tarus philadelphia. Bonaparte's Gall.}

Summer resident about the larger lakes. Winnipeg: Tolerably com. mon here in fall (Hine). A few breeding in the marsh of Swan Oreek, not far from Shoal Lake (D. Gunn). Breediug in great abundance on all the large lakes of the prairie-region, chiefly west of Manitoba (Maconn). One in Sirithsonian Institution from Nelson River (Blakistou). Poriage la Prairie: Albundant during the spring migration, and some probably stay to breed, as I have occasionally seen single birds about the prairie sloughs during the summer (Nash). Severn House; fortunately several specimens of this gull have been received; it is rare in collections, but would appear not to bo so in Budson's Bay (Murray).

\section{Eterna fornterl. Forster's Tern.}

Summer resideut about the large lakes; bi eeding in large numbers on the b irders of Lake Wiunipeg in the latter part of May; at Shoal Lake, saw Forster's terus in considerable numbers; they nest among the reels; Sulkirk Settlement (D. Gunn). Shoal Lake, Mas 15; com. n:on (Christy). Breedling abuulantly in Lake Manitoba, Waterhen River, and Lake Winnepegosis (Maconn). Portagela Prairie: Abuudant during tho spring and autumn migrations; probably breods, as I have seou a fow in summer (Nash).

\section{Bterna hirundo. Common Teru. Sen 8 wallow.}

Common summer resident on the large lakes; feeding largely on small fish. Winnipeg: Summer resident; tolerably common (Hin仑). One 
taken on Lake Winnipeg, June 16 (Humicalt). Breeding on Lake Manitoba, Waterhen River, and Lake Winnipegosis (Macoui). Portage la Prair.e : Tolerably common during spring anit autumn migrations; a few remain about Lake Manitoba during the summer (Nash).

There are numbers of terns breeding annually at Shoal Lake; some of them on emall, gravelly islands. These form their nests by removing the gravel, making hollows in which they lay their eggs; otbers of them take up their abode among the reeds and rnshes. Hero, with great induetry and ingenuity, they make their nests of reeds and grase, fixing thein in their place to keep them from floating away. When in Lake Winuipeg, in 186\%, I observed that the terus which occupied sandy and gravelly islands made their nests as those do on the gravelly islands in Shral Lake; and the terns found on the rocky island on tho east side of the lake chose for their nests depressions and clefts in the surface of the rocks. These they line carefully with moss; three or four eggs being laid in each nest; thus exhibiting a remarkable example of Instinct, whieb teaches these litile creatures that their egge laid iu soft sand and in loose gravel are safe withont any lining to protect them, but that when laid in hollows and clefts of rocks, lining to protect their eggs and young from injury by these hard, and at night cold, materials would be indispensable. (D. Gunn.)

16. Eydrochelidon nigra surinamensis. Black Tern, or Marsh Tern.

Abundant summer resident; chiefly about the pratrie ponds, lleal waters; breeding at Pembina; Mouse River at the boundary (Coues). Winuipeg: Summer resident; abundant (Bine). Abundant in lied River and Selkirk Settlements (Brewer). Prairie Portage; plains of the Souris (Hind). Portage la Prairie: Abundant summer resident on all the large prairie sloughs, in which they breed; first seen, May 11, 1884, May 25, 1885; last sten, September 9, 1884 (Nash). Breediug very abundantly in all marshes from Portage la Prairie westwari, 1879 , and in less numbers in tho wooled region, but generally dis. tributed (Macoun). Carberry : A bundant; summer resident; breediug also in all ponds along the trail from Carb $\rightarrow r r y$ to Port Ellice (Thomp. 8ou). Brandon: Breeds in great numbers (Wood). Shell River: 1885, first seen, eleven, on May 18; seen every day afterwards; is common all summer, and breeds here; Indian name, "K'usk" (Calcutt). Qu'Appelle: Common summer resident; breeds; arrives Mav 18 (Gu, ru. sej). Severn House (Murray'.

On June 11, 1882, went in the morning with two brothers to the luke in the sand hills east of old Dewinton; saw there large numbers of marsh terns. They np peared to be nesting in a weedy expanse far out in the lake, but it was surrounded by deep water, so that I could not come near it to seek for egge. The birds came flying over my head, in company with numbers of blackbirds, and resented my intrusion by continually orying in their charncteristic mannor.

August 4. The black terus are beginning to gather in flocks; leave the ponds anil skiı about over the open prairie.

On July 8, 1883, went southwest to Smith's Lake; found a number 
on Lake (Macouin). nil autumn e summer

of them on making holle anong the ke their nests oating away. upied sandy nds in 8hral ake chose for hey line care. exhibiting a at their eggs oct them, but gs and young jensable. (D.

\section{Tern.}

onds, lead ry (Coues). nt in lied lains of the dent on all 1, May 11, Breeding west wari, terally dis. ; breeding ce (Thomp. iver : 1885 , is common (Calcutt). 18 (Gu, rn.

to the lake umbers of ise far out could not $y$ hend, in trusion by cks; leave a number of tern's uests, just finished, apparently, as they were clean, but empty, and the old birds continued flying above us an.t screaming their re. sentment.

On July 5, 1884, at McGee's Lake, Carberry, I fonnd the terns just beginning to lay. Each nest is a mere handful of floating reeds, slightly moored to others growing in the deep water, where they are found. The whole structure is just ou a level with the surface of the water and entirely wet; on this are the eggs, much the same color as the reeds, and as wet as eggs can be.

It is a remarkable fact that, although this species is abundant in all parts of southwestern Manituba, and I have often searched in various lakes with a flock of terus screaming about my ears, yet I have never before found either nest or eggs. Ou this occusion I found three eggs in one nest; several nests with two eggs; one or two with one, and one or two empty nests just completed.

On July 9 the terns were numerous everywhere on the prairie. Timed and counted the wing beats of sereral as a basis for calculating their rate of flight; one made 54 beats in 9 seconds; another, 28 beata in 9 seconds, a third 30 in 10 seconds. July 6, observed one make 27 beats ir. 10 seconds. July 12, saw another make 15 beats in 5 seconds, show. ing that about 3 is the average number of beats to the second. July 5 I had an opportunity of measuring the distance a tern covers with 8 beats; it was 24 yards.

August 14: Terns are abundant now on the open prairie; it is a com. mon sight to see this bird zigzagging about in pursuit of the large dragou flies, until, at length, having secured as many as it could conveniently carry, it suddenly ceased the fantastic maneuvering for the swifter beeline, and inade straight for its twin nestlings in the reedy expanse of some lake far away.

To.day, I made a caleulation of the speed; one hird covered 70 yards with 14 beats, $i$. e., 5 yards per beat; I find they usually give 3 beats per second; this, therefore, is 15 yards per second or 31 miles per hour; much less than I expected. This black inland member of a white marine family is abundant abont all the weedy sloughs and lakes of the Manitoban prairie regions. It seems not to subsist on fish at all, but chiefly on dragon flies and various aquatic insects. It finds both ite home and its fool in the marshes usually, but its powers of flight are so great that it may also be seen far out on the dry open plains scouring the country for food at a distance of uiles from its nesting ground.

The voice of the species is a short, oft-repeated scream, and when any known enemy, be it man or beast, is found intruding on the privacy of their nesting ground the whole flock comes hovering and dashing about his head, Nereaming and threatening ir a most rociferous manner. Under such circunstances it is the easiest thing imaginable to procure as many specimens as may be desired. When one of the flock falls wounded in the water, its fellows will repeatedly dart down and hover 
low over it, but I have nerer seen any attempts made to assist it in escaping, after the manner ascribed to some of the family.

Besides aquatic insects the Black Tern feeds largely on dragon flies which it adroitly captures on the wing. The bird may frequently be seen dashing about in a zigzag manner so swiftly the eye cau offer no explanation of its motive until, on the resumption of its ordinary flight, a large dragon fly is seen hanging from its bill and sufficiently accounts for the erratic movements of the bird. After having captured its proy in this way I have frequently seen a tern apparently playing with its victim, letting it go and catching it again, or if it is nuable to fly, dropping it, and darting under it to seize it again and again before it tonches the water. After the young are hatched, a small flock of the old ones may be seen together leaving the pond and winging their way across country to some favorite dragon.fly ground. Their flight at first is uncertain and racillating, but as soon us one has secured its load it returns with steady flight and in a straight line to its nest.

Under ordinary circumstances I was always impressed with the idea that the tern was very swift and entered into a series of elaborate calculations to ascertain the rate of its flight. A large number of obser. vations resulted in an average of three wing.beats per second, with the greatest of regularity; another series of observations, not so satis. factory, allowed a distance of 5 yards to be traversed at each, beat. This gave only the disappointing rate of something over 30 miles per hour, but this was at the uncertain foraging flight. Once the mother tern has secured her load of provender, a great change takes place, as already mentioned; she rises high in air, and I am sure she lloubles her former rate of speed, and straight as a ray of light makes for bome. It is said that many birds can not fly with the wind; not so the tern; for now, if there be a gale blowing her way, she mounts it like a steel and adis its swiftness to her own, till she seems to glance across the sky, and ranishes in the distance with a speed that would leave far behind even the eagle. so loug the symbol of all that was dashing and swift.

\section{Phalacrocorax dilophun. Double-crested Cormorant. Crow Dnck.}

St smer resident about the large lakes of the westward regior when there is plenty of fish; once observed on Red River near Pemlina (Coues). Winnipeg: Summer resident; not rare, and found breeling at Lake Winnipeg; occasional on Red River (Hine). Breeling at Shoal Lake and Selkirk Settlement (D. Gunn). Shoal Lake: Plentiful ; lreeding; May 16, 1887 (Uhristy). Ossown: Breeding (Wagner). Portage la Prairie: Tolerably common during the spring migration, on the Assiniboine and Red Rivers, and the wooded sloughs adjacent to them, but very seldom seen in the autumn; first seen April 24, 1885, April 20, 1886; on October 8, 1886 ; I saw one flying up the Red River southward; these birds are very wild and difficult of approach when on the water, rising with a great flapping before one can get within 200

yards gosis it 13 ; ne (Oalcut breedin on isla

Fort $Q$ the end three or builds or when a their exc that I k they sit

Com bina in (Cones) breedin commo in the 8 specim. Island : was coI saw, tw 1884, s (Nash). wheelir figure, In gre: up, ani 1886, f only re seen, $N$ very pl son Is in nnm Winne one or kiston) extent. the oorn with the opot. A 
yards of them (Nash). Very abundant; breeding on Lake Winnepegosis iu 1881 (Macoun). Shell River : 1885, first seen, four, on May 13; next seen, two, on May 14; a transient visitor only; not breeding. (Calcntt). Qu'Appelle: Rather common summer resident; April 25, breeding north of the Touch wood Hills; nesting on the trees growing on islauds in the lakes (Guernsey).

Fort Qu'Appelle, May 19, 1885. The Cormorant comes bere in large flocks towarde the end of April; it is called by half-breeds the Crow Duck; in its flight it flaps for three or four strokes and then saile; it is an expert diver. The half-breede say that it bnilde on islands in the lakes north of here, building its neste on trees. They say that when a man lands on one of their breeding places the birds fly over him and drop their excrement on him. I have been told this by several. They do not breed here that I know of, but there are always several knocking about during the eummer; they eit on the bars with the pelicans. (Geo. F. Gue sey).

\section{Peleoanul erythrorhynchos. American White Pelican.}

Common summer resident about the large lakes; one taken at Pem. bina in May; observed at Mouse River on the boundary in September (Coues). Winnipeg : Summer resident; common about the-large lakes ; breeding at Shodl Lake (Hine). Red River Valley : Summer resident; common; breeds at Shoal Lake(Hunter). Shoal Lake (Christy). Breeds in the smaller lakes near Lake Winnipeg, and northwestward ; several specimens shot in Lake Winnipeg in October, 1880 (Bell). Swamp Island : 1885 , first saw. two on May 24 ; next seen May 31, after which it was common; it breeds here ; in fall, last seen September 12, 1886, first saw, two, ou April 29; bulk arrived May 27 (Plunkett). September 1, 1884, saw a flock of five on Lake Manitoba; the only ones I ever saw (Nash). Waterhen River: Octobar 3, 1858, a large flock of pelicans, wheeling in circles far above, suddenly formed into an arrow-headed figure, and struck straight south; Oak Lake, sume Pelicans (Hind). In great numbers at the head of Lake Winnepegosis or abont haif wi.y up, and evidently breeding, 1881 (Macoun). Carberry: November 5, 1886, found remains of a dead pelican in the hills near Smith's Lake; only record (Thompsou). Dalton: 1889 , first saw one on May 4 ; next seen, May 5; rare (Yoemans). Qu'A ppelle: Common summer resident; very plentiful on the lakes last year (1884); towards the migratory season I saw flocks of npwards of 500 birds (Guernsey). Pelican observed in numbers at the Grand Rapids, where the Saskatehewan enters Lake Winnepeg, on the 25th of September, and a few days after a scattered one or two; I believe they do not range east of Lake Winuipeg (Bla. kiston).

These birds until the last fer years were ir the habit of breeding in large nnmbers at Shoal Lake, 50 miles from Winnipeg. In the summer of 1878 , on the 1st of June, I counted six hundred of their egge ( $($ ) in uests on a small lsland of abont haif an acre in extent. The neste consist only of a slight depression in the sand. These birds and the cormorants are great friends; the nests of the latter were intermixed every where with those of the pelicans. I connted seven hundred egge of the cormorant on this spot. Aithough the peliesn's home and nesting place is au abode of filth, they keep 
themselves exceedingly clean. Their flight I consider nore beaut fal and gracefal even than that of the swan. (Richard H. Hunter in MSS.)

Fort Qu'Appelle, May 19, 1885 . Sone years the pelicans are more numerous than others. Laet year they were very thick all summer, and towarils the end of euminer it was no unusual thing to see forty or fifty in a flock sitting on the water. They are reported to breed in large numbers on Long Lake, 40 miles west of here. (George F. Guernsey in MSS.)

\section{Merganser americanus. American Merganser. Sheldrake.}

Summer resident, freqnenting only living water. Winnipeg: Summer resident ; rare; Lake Wiunipeg (Hiue). Red River Valley: Suumer resident; common; breeds at Slioal Lake (Hunter). Breeds abuudantly on the rivers emptying into Lake Winuepegosis, and on all the rivers visited by me in Manitoba; I never observed this bird on still water during the breeding season; they feerl only on fish, and are found only ou clear running streans where fry are abuudant (Maconn). Qu'Appelle: Tolerably common suminer resident; May 5 (Guernsey).

20. Merganser serrator. Red-breasted Merganser. Fish Dnok.

Summer resident, chiefly on living waters. Winnipeg: Summer resident; rare; Lake Winnepeg (Hine). Red River Valley: Summer resident; tolerably common; breeds at Shoal Lake (Hunter). Breeds in all the northern streams and ponds; feed largely on vegetable matter and are quite edible (Macoun). Carberry : August 21, 1884, at Hope's Lake, shot a merganser; rare here (Thompson). Qu'Appelle: Tolerably common; summer resident; May 1 (Guernsey). Trout Lake, Severn House (Murray).

\section{Iophodytes cuoullatus. Hooded Merganser.}

Summer resident, chiefly inhabiting drainage, that is, dead water; breeds; Turtle Mountain and Mouse River along the boundary (Ooues). Dufferin : Arrived between April 20 and 25 (Dawson). Winnipeg: Summer resident; common; breeding at Lake Winuipeg (Hine). Portage la Prairie: Tolerably common; summer resident; first seen April 27, 1885, April 23, 1886; abundunt on La Salle River and on Horse Oreek near Westbourne (Nash). Found in all the smaller ponds and lakes; very common in streams around the Porcupine Mountain; feeding on vege. table substances and quite edible, unlike M. americanus (Macoun). Carberry : Tolerably common summer resident; breeding (Thompson). Bhell River: 1885, first seen, eight, on May 11; is commou all summer and breeds here (Ualcutt). Qu'A ppelle: Common summer resident; breeds; arrives April 20 (Guernsey). Trout Lake (Murray).

\section{Anas bosohas Mallard.}

Very abundant.; summer resident; general distribution in grasey freshwater marshes, etc.; breedls abunduntly throughout the region in suitable places, from Pembiua aloug the boundary to the Rockies

Island:

common seen, $t w$ 1885, fir on Apri mon; su till after of the N ary (Me Souris 1 City ; n Brandor March 2 breeds breeds ; every da April 5 ray). $\mathrm{Ne}$ 1773).

June 1 across a leading ! perhaps and dry. usual st ones sca hidden $t$ ing four gather : believin, On Oc lain in $t$ family $a$ water or they are ing over success : on insec the wat the rush up in $\mathrm{ful}$ which $t$ for your 
ind gracefal

nerous than lof suminer

c. They are (George F.

se.

eg: Sum.

ley: Suul-

eds abull-

on all the

rd on still

are founcl

(Macoun).

erusey).

ik.

nmer resi. nmer resieeds in all latter ancl pe's Lake, ably com. arn Bouse

ad water; (Ooues). eg: Sum. Portage la 27, 1885, cek near ces; Tury on vege.

n). Car.

n). Shell pmer and ; breeds;

\section{g grasay} region in Rockies
(Ooues). Dufferin : Arrived between April 15 aud 20 (Dawson). Winnipeg : Summer resident; abundant(Hiue). Ossowa : O'mmon; breeding ; 1885, first seen, two, on April 6; next seen, April 13 (Wagner). Swampy Islund : 1885 , first seen, two, on April 16; next seen, April 20 ; becume common April 26; breeds here in fall; last seen October 1; 1886, first seen, two on April 16 ; next seen, April 17 ; (Plunkett). Oak Polut: 1885, first scen, two, ou April 7 ; next seen, April 8 ; became common on April 11; breeds here (Small). Portage la Prairie: 1884, very common; summer resident ; first seen, March 30 ; a fow sometimes remain till after the snow covers the ground (Nash). The most abundant duck of the North west, breeding in nearly all the marshes north of the boundary (Macoun). Carberry: Abundant in migration; a few brecd; Souris Plain; Turtle Mountain ; Long River; Fingerboard; near Rapid Uity; near Two Rivers; Pine River; Portage la Prairie (Thompson). Brandon : April 13, 1882 (Wood). Daltou : 1889, first seen, four, on March 21; next seen on March 23; became common on March 26; breeds here (Youmans). Shell River: Common suinmer resident; breeds ; in 1885, first seen, twelve, on April 6 ; afterwards seen every day (Calcutt). Qu'Appelle : Coinmon summer resident; breeds April 5 to 15 (Guernsey). Trout Lake Station and Severn Hunse (Murray). Near Cumberland House are fund in vast multitudes (Hearue, 1773).

June 11: While roaming in Bpruce Bush, to-day, I came suddenly across a wild duck (Mallard) with her newly hatched bruod. She was leading them to the water, which was a considerable distance away, perhaps a quarter of a mile, and in this locality the forest was high and dry. The old duck ran to meet me and then put in practice all the usual stratagems to cover the retreat of her brood; mean while the little ones scattered and ran, "peeping" in all directions, and soon all had hidden themselves from view, except five, which I caught. The remain. ing four or five I did not try to ger, but left them for the mother to gather together again. My little captives I took home with we, fondly believing I could rear them.

On October 30, 1886, saw three Mallard at Smith's Lake. I have often lain in the long grass on the bank of some pond aud watched the whole family as they played about on the glassy surface, now splashing the water over the backs, apparently to show how they mean to do it when they are big rather than for any present benefit, and now rushing pattering over the surface in pursuit of some passing fly and generally with success crowning the effort, for when young they feed almost exclusively on insect food. I touched one of the tall stems so that the top shook; the watchful mother failed not to observe that there was something in the rushes, and slowly led her brood in another direction; or if I stood up in full view, she gave to her startled brood the watchword of alarm, which to judge from her actions may be translated " scatter and run for your lives into the rushes while I divert the brute's attention." 
There have been times when it was the necessity for food that led me where I have observed such scenes as that described, but I can say truly that each time the brave mother was ullowed to go in peace and the hunt was prolonged until another though perhaps a less palatable victim was found and sacrificed.

They arrive early in April, frequently before the lakes or large sloughs are free from ice, resorting to the wet prairies and stubble-fields; the great bulk are paireci when they reach hero and they ooon commence vesting. their nests being made in all sorts of places. I have found thein in the marshy slouglis on the opeu prairie, near water usually, and once in the bush at least a half a mile from a very small stream that aiways dxied up during the summer, but which was the only water for a long distauce.

About the middie of May the females commence to set; the drakes then molt, losing their briliant plumage; whilst uudergolng this change they gather together into emall flocks of about five or six and hide themselves in the rushes, from which it is very hard to dislodge them even with gond dogs.

In September they gather into flocks, young and old together, and visit the wheat and barley stubbles, rapidly becoming fat; the drakes at this time begin to show the green feathers on their heads, and by the time they leave they have acquired their perfeet plumage.

A few frequently remain for some little time after the enow has covered the ground; these I have seen feeding around the base of the stacks and resorting to Lake Manitoba for water; in 1885 they were abundant up to November 9, but left on the day, after, for on the 11th I saw the last of the season, a eingle bird only.

On the 15th of September, 1832, I ehot a large drake, which had pare white pinion feathers and a broad band of white from the usual ring around the neck to the breast; this bird was with soven others, all of the usual color and eize. (Nash, in MSS.)

\section{Anas obscura. Black Duck. Dusky Duck.}

Very rare summer resident. Winnipeg : Summer resident; rare; only two specimens in 10 years, one at Long Lake, one at Lake Winnipeg (Hine). Red River Valle, : Very rare; Manitoba is their most western limit (Hunter). I have received a specimen and seen others from York Factory (Blakiston).

\section{Anas ntropera. Gadwall. Gray Duck.}

Rare summer resident; abundant throughout the region along the Bonndary from Pembina to the Rockies; breeds (Oones). Winnipeg : Summer resident; tolerably common (Hine). Red River Valley : Summer resident; tolerably common at Lake Manitoba (Hunter). Breeding on Shoal Lake (D. Gunu). Only one specimen shot on the Assiniboine, September, 1881 (Macoun). Portage la Prairie: Rare; have shot a few in the autumn near Lake Manitoba (Nash). Qu'Appelle: Common summer resident; breeds; April 20 (Guernsey).

25. Anan amerioana. Baldpate, or Widgeon.

Tolerably common summer resident; abundant throughout the region along the boundary from Pembina to the Rockies; breeds (Cones). Dufferin : Arrived between April 20 and 25 (Dawson). Winnipeg: Sum- 
od that led ut I can say 1 peace and ss palatable

ughs are free alk are paireci ng mado in all 2 prairie, near small stream ter for a long

then molt, lostogetlier into which it is

the wheat and in to show the acquired their

ed the ground; to Lake Manift on the day, white pinion : to the breast; , in MSS.)

; rare; only - Winnipeg post western $s$ from York

n along the Winnipeg : alley : Sum.

Breeding Assiniboine, o shot a fow : Common

t theregion ds (Cones). aipeg: Sum. mer resident; tolerably common (Hine). Selkirk Settlements: Breed. ing; Jaku Winnipeg in the breeding season in considerable numbers (D. Gunn). Swampy Island : 1885, first seen, four, on May 10; next seen, May 11; bulk arrived May 12; is common, and breeds here; in fall, last seen, Octoher 2; 1836, first four on May 10; bnlk arrivell on May 13 (Plunkett). A specimen from between Lake Winnipeg and Hudson Bay in Smithsonian Institution (Blakiston). Portage la Prairie: Abundant summer resident; breeding at Lake Manitoba and in all the sloughs in this vicinity; this is the last duck to arrive in the spriug and. the first to leave in the fall ; in 1881, first seen, April 16 (Nush). Silver Oreek: July 5, 1882, shot a Widgeon, female; apparently breeding; length, 18; extension, 33 ; gizzard full of shell-fish (Thompson). Shell River: 1885, first seen, a pair on May 12; next seen, four, on May 23 ; is common all summer, and breeds here (Ualcutt). Frequent on the Assiniboine; 1881 (Macoun). Qu'Appelle: Common summer resident; breeds; April 20 (Guernser).

\section{Anas carolinenais. Green-winged Teal.}

Abundant migrant; many breeding; extremely abundant throughout the region along the boundary from Pembina to the Rockies in August; doubtless some breed (Coues). Dufferin: Arrived between 15th and 20th (Dawson). Winnipeg: Summer resident; abundant; breeding (Hine). Swampy Island : 1885, first seen, two, on May 3 ; next seen, the bulk, May 6; is tolerably common, and breeds here; in fall, last seen September 1; 1886, first seen five on May 8; bulk arrived May 10 (Plunkett). Very common near Norway Honse; scarce northward (Bell, 1880). Portage la Prairie: 1834, abundant migrant and common sum. mer resident, arriving at about the same time as the Mallard, but leav. ing as soon as the sloughs are frozen over; I have found flappers as late as the 15th of August (Nash). Rarely found breeding on the plains; apparently goes further north; in immense flocks on the Assiniboine in the fall of 1881 (Macoun). Oarberry : common; breeding; Silver Oreek, Rapid Oity (Thompson). Dalton : 1889, first seen, two, on April 15; next seen on April 16, when it became common; does not breed here (Youmans). Braudon : April 20, 1882 (Wood). Shell River : 1885, first seeu, a pair on May 2; afterward seen every day ; is common all 'summer, and breeds here (Ualcutt). Qu'Appelle: Common summer resident; breeds April 5 to 15 (Guernses).

On June 29, 1882, at Rapid City, Dr. A. S. Thompson shot a Green. winged Teal with his ritle. Although shot through the belly it was not killed, but flew with its entrails trailing, and it required a charge of dust shot to fluish it. It was a male; length, 15; extension, 23; gizzard full of shell fish. This species is very abundant throughout the whole of the pondy prairie region from here to Oarberry. It is usually mat with in pairs and is of a very affectionate disposition, for if one be shot the other either renains to share its fate, or if it does fly at first, usually 
returns almost immediately to the side of its mate. I found it an ex. pert diver, for often one of them would disappear at the approach of the gunner and be seen no more; doubtless it had swain under water to the nearest reed-bed, in whose friendly shelter it was securely hiding.

On July 5, at Silver Creek, came across a female Green-winged Teal truveling with her brood of ten young ones across the prairie towards a large pool. The mother bird was in great grief on finding that she was discovered, but she would not fly a way; she threw herself on the ground at my feet aud beat with her wings as thongh quite unable to escape and tried ber utmost to lead meaway. But I was familiar with the trick and would not he beguiled. I caught most of the tiny yellow lowulings before they could bide and carried them carefully to the pool, where soon afterward the trembling mother rejoined them in safety.

This species, I think, uulike the blue-wing, usually nests quite close to the water, so that it was probably owing to the drying up of the pond that this newly hatchel brood found themselves forced to take an overland journey of considerable extent before they could find a sufficiency of water.

\section{Anas discors. Blue-winged Teal.}

Very abundant; summer resident; general distribution in the prairie regious; along the boundary, Mouse River, in fore part of August becomes rery abundant; doubtless breeds (Coues). Winnipeg: Sum. mer resident; abundant; breeding (Hine). Sparingly at Shoal Lake and Lake Winnipeg (Brewer). Swamp Island: 1885; breeds here; last seen August 26 (Plunkett). Sluoal Lake, May 19,1857 (Christy). Port. age la Prairie: Very abundaut; summer resilent, and like the mallard nesting wherever it tukes a fancy to do so; in $188+$ first seen April 16 (Nash). Breels ubunclantly around murshy ponds in the prairie conntry; exceedingly abundant in full of 1880 ; rare in Assiniboiue in September, 1881 (Macoun). Carberry : Common; breeding; Sonrls Plains, Turtle Mountain, Long River, Rapil City, and the whole south slope of Riding Mountain (Thompson). Dalton: 1889, first seen, one on April 18; next seen, Muy 15, when it became common; breeds here (Youmans). Shell River; 1885, first seen, a pair ou May 2, afterwards every day; is common all summer und ioreeds here (Calcutt). Qu'Ap. pelle: Common summer resident; breeds May 10 (Guernsey).

I have frequently remarked that luring the breeding season this species may be seen coursiug over and around the ponds In threes, and these when shot usually prove a male and two females. After dark they muy be illentifled during these mnneuvers by their swift flight and the peculinr chiruing, almost a twittering, that they indulge in as they tiy.

Ou August 10, 1882, at Markle's Lake, shot a Blue-winged Tenl. This sheet of water is not more than 3 ucres; it has hard bauks, ulmost ell. tirely without rushes or other cover, and is a mile or more from the 
nd it an ex. proach of the water to the hiding. winged Teal rie towards a that she was n the ground le to escape iar with the tiny yellow $y$ to the pool, in safety. ts quite close 10 of the pond iake an over. a sufficiency

In the prairie $t$ of August nipeg: Sum. ; Shoal Lake ds here; last risty). Portthe mallari een April 16 the prairie ssiniboine in ding; Sonris whole south rst seen, one breeds here 2, afterwards tt). Qu'Ap. ey).

senson this it threes, and After diurk swift flight ndulge in th

al Tenl. This s, nlmost ell. pre from the nearest pond. This duck is very abundant in the country, and I thluk it usually nests much farther from the water than any of its near con. geners. Like the Green-wing it is a good diver, but it is less wary and more easily shot; it seems to prefer the smallor ponds and leaves the large sheets to the Mallard and other large dueks.

\section{Anas cyanoptera. Cinnamon Teal.}

Very rare; straggler; I have taken the Cinnamon Teal at Oak Lake, and I think also at Lake Manitoba, but during fifteen years' residence in Manitoba I have only seen five or six specimens (R. H. Hun. ter).

\section{Spatula clypeata. Shoveler or Spoonbill.}

Abundant summer resident, of geueral distribution; abundant throughont the region along the boundary from Pembina to the Rockies; breeding on Mouse River(Cones). Dufferin: Arrived between April 20 and 25 (Dawson). Winuipeg: Summer resident; abundant (Iine). Breeding at lied River, Shoal Lake, and Lake Winnipeg (Brewer). Swampy Island : 1886, tirst seen, six, on May 28; abundant summer resident (Plunkett). On Lake Winnipeg, the young were nearly full grown in the beginuing of July (Bell, 1880). Shoal Lake: Breeding May 17, $18 \times 7$ (Christy). Portage la Prairie : 1884, common summer resident; breeds in most of the sloughs near here; I havo only once seen anything like a floek of these bircls, and then there were not nore than a dozen of them; they arrive late and lepart as soon as the shullow waters they frequent are frozen; in 1884, first seen April 10 (Nush). Observed great uuinbers in August on the prairie ponds about Pleasant Hills; breeding on ponds throughout the prairle, but more abundantly throughout the copserrood region (Maconn). Bran. don, Pembina, and Rapid City: Brselling (Thompson). Dalton: 1889, frst seer, one on April 16; is common, and breels here (You. mans). Shell River: 1885, first seen, a pair on May 8; next scen, fonr on May 22; is common all summer and breeds here (Cnleutt). Qu'Appelle: Common summer resident; breeds; May 1 (Guerusey). Trout Lake (Murray).

\section{Dafila acuta. Pintail.}

Common summer resident of genernl distribution; abundant through. out the region along the bomilary west warl from Pombina, in summer us well as in fall (Cones). Dufferin: Arrived between April 15 an!? 20 (Dawsou). Winnipeg: Summer resident; abundant (Hine). Red River to Hulson's Buy (Blakiston). Breeds near Norwiny Honse (Bell, 1880). Osowa: Common ; breelling; 1885, Arst seen, one on April 7, next seen April 16; beeame common A pril 20; last seen, thirteeu, on November 1 (Wagner). Portage ln Pruirie: A bumlant; summer resident; frst seen in 1884, A pril 16; urriving early, generally with the Mallard, but leav. 
ing much earlier, the first frost driving them out (Nash). Carberry: Tolerably common summer resident; breeding; Souris Plain, Turtle Mountain, Fingerboard, near Kapid City (Thompson). Dalton : 1889, flrst seen, about ten, on March 21; seen every day afterwards; becaine common on March 23; breeds here (Youmans). Braudon : April9, 1882 (Wood). Breeding on the prairies south of Pipestone Creek (Macoun). Shell Rirer: 1885, first seeu, four, on April 20, afterwards seen every day, male and female; is common all summer aud breeds here (Calcutt). Qu'Appelle: Common summer resident; breeds April 5 to 15 (Guernsey). Trout Lake Station and Sereru Honse (Murray).

\section{Alx sponsa. Wood Duck.}

Rare summer resident; several small flocks in latter part of September, north of Red River, in Minuesota, feeding on wild rice (Kennicott). Rat Portage: Octover 10, 1886, found the head of a male. Wood Duck lying on the shore (Thompson). Winnipeg: Summer resident; rare (Hine). I have seen the Wood Duck (Aix sponsa) at Westbourne, and it is always to be found along Cook's Creek, east of Winuipeg (Hun. ter). Portage la Prairie: $\Delta$ rare and local summer resident, but I think increasing; previous to September 21, 1884, I never saw any in this neighborhood, though I had heard that a few pairs always bred on the White Mud River, near Westbourne, on that day; I saw two on the Assiniboine the following year; two or three broods were raised bere, out of which, in September, I shot several, and on the 9th of October I killed one of the handsomest drakes $I$ lave ever seen; its plumage was simply perfect (Nash). Observed on Lake Winnepegosis by Mr. Tyr. rell (Macoun). Carberry: A single pair taken in 1883 (Thompson). Qu'Appelle : I know of one being shot here in fire yeurs (Guernsey). A male killed at Cumberland House, Jume, 1827 (liiehardson). Mr. Hine, of Winnipeg, showed me some fue specimens taken at '.ake Winnipeg; he described it as regular, though not common, in the mouths of such creeks as flow through the heavy timber into Lake Winnipeg; Devils' Creek is a favorite place, and here they are found feeding largely on the wild potato which grows on the orerhanging banks, so that the bird may gather it without leaviug the water; Hudson's Bay; Moose Factory ; Tront Lake Station (Murray).

\section{Aythya americana. Rerl.hoad.}

Common sum mer resident; breeding abundantly tlıroughout the region along the homblary from Pembinn to the Rockies (Coues). Swamp Islund: Breeds liere; last seen September 11 (Plunkett). Winueneg; summer resident; abundant (Hine). Breeding at Oak Point Lake, Munitobn, Shoul Lake, and Selkirk Settlement (D. Gunn). Portage lit Prairie: Abundant; summer resident; breeding in all the lakes and large sloughs; I. hive frequently shot flappers on the 15th of $\Lambda$ ugust; they arrive as soou as the rivers are open and stay until no open wate"

is left;

marshe summei a pair 0 and bre breenls;

Oak $\mathbf{P}$ americano When I v taining stating i to rob ot tho canvi great nu

Uncol ary) I se however nipeg : (Hine). Pointan seen, six breed lie ice on lt common 1882, du they are for on th clealer's received informed vould sc (Guernse I aun po: pring ove luring th f one oan 885.)

4. Ayth Comm 5 and 3 River $\mathbf{8}$ River $\mathbf{V}$ bonly br tunn). ortage 
Carberry: ain, Turtle Iton : 1889, Is; became pril9, 1882 (Macoun). seen every e (Caleutt). 15 (Guern.

tof Septem. Keunicott). Wood Duck ident; rare bourne, and aipeg (Hun. , but I think any in this bred on the $\checkmark$ tro on the raised here, of October I plumage was by Mr. Tyr. (Thompson). (ernsey). A Mr. Lline, 3 Winnipeg; hths of snch peg; Devils' g largely on , so that the Bay; Moose

ut the region es). Swamp Winnepeg; Point Ianke, Portage lii le lukes and of Augnat; bopeu watp: is left; in 1884, first seen April 16 (Nash.) Breeds abundantly on the marshes of Waterhen River(Maeoun). Carberry : Tolerably common; summer resident; breeding (Thompson). Shell River: 1885, first seen, a pair on May 3, afterwarls seen every day ; is common all summer and breeds here (Caleutt). Qu'Appelle: Common summer resident; breeds; April 23 (Guernsey).

Oak Point. We procured some lnck nests aut anong them were two Aythya americana, (Rell-head ilncks' nests), ono containing eight eggs, the other nineteen. When I was there in 1865 wo fonnd one belonging to the samo kind of duck con. taining nineteen or twenty egus. The Indinus accuso this dnck of dishonesty, stating it to havo very little respoct for the rights of property, being inelined to rob other dueks of their eggs and place them in its own nest. This speeies and the canvas-back are both found at Shoul Lake and at Manitoba, but nowhere in great numbers. (D. Gunn.)

\section{Aythya vallisneria. Canvas-back.}

Uncommon; a few breel ; at Turtle Mountain in July (at the bound. ary) I saw several broods of partly grown young; in most of the region, however, the birl is less numerous than the Red-heal (Coues). Win. nipeg : Fairly common on Lake Manitoba, but not generally breeding (Hine). Red River Valley : Transient visitant; rare (Hunter). Oak Pointand Shoal Lake : breeding (Gunn). Swampy Islands : 1885, tirst seen, sixty, on May 19 ; next seen, May 20; last seen Miny 25; does not breed here; is rery abundant in fall and spring amongst open places in ice on lake (Plunkett). Portage la Prairie: 1884, first seen April 16; common in spring, partienlarly if the lowlants should be flooded; in 1882, during the spring frestiet they were abundant, in the antumn; they are less frequently scen; some, howerer, breel on Lake Manitoba, for on the 18th of September, 1886, I saw four young birts in a game dealer's shop in Winnipeg, the proprietor of which told me he had just received them from there, and a friend who knows the birds well also informed me that he had shot them on the same inke when they could seareely fly (Nash). Qu'Appelle: Oommon migrant; April 23 (Guernsey).

I au positlvo that the oanvas-back nover breeds in Manitobn. I liave shot in the pring overy year for tho past fifteen years, aud have not seen ten canvas-bask aluoks furing that time. I have occusionally shot them in the autumu, in the proportion f one cunvae- bnck to two hinnilreal other ducks. (Ricb H. Hunter, in MSS., May, 885.)

4. Aythya marlla nearotioa. American Senup Duek. Big Blıo-bill or Biack- heal.

Common migrant; a fow breel. Dufferin: Arrivel between April 5 and 30 (Dawson). Specimen in Smitlisonim Institution, from Red River Settlement (Blakiston). Wimuepeg: Abundunt (Hine). Red River Valley : Abuudant migrnuts, but I ean not concur that it culn. nonly breeds in Manitobn (Hunter). Breeiling at Lake Winnipeg (D. tunn). A few breeding in Lake Wimnipegosis, June, 1881 (Mncouni). Portage la Prairie: Fall migrant; commun in spring, arriving as 8000 Proc. N. M. 90-31 
as the rivers are open; not so frequently obtained in the antumn, principally, I think, because it confiues itself to the large lakes, seldom visiting the creeks or sloughs at that season; it remains until it is frozen out; in 1884, first seen April 16 (Nash, in MSS.).

Carberry : Abundant; migrant(Thompson). Qu'Appelle : Common summer resident; breeds; arrives April 20 in flocks, with lesser Bluebills and Ring-neck (Guernsey).

\section{Aythya affinis. Lesser Scaup Duck. Little Blue-bill.}

Abundant summer resident, of general distribution. Winnipeg: Abundant; breeding (Hine). Red River Valley : Abundant, chiefly in autumn; not commonly breeding (Hunter). Swamp Island : 1885, first seen, four, on May 12 ; next seen May 13, when it becomes common; is abundant and breeds liere; 1886, first seen, two, on May 5 ; bulk ar. rired on .May 11 (Plunkett). Shoal Lake: May 19, 1887 (Christy). Portage la Prairie: Abundant summer resident; breeding on all the prairie sloughs of any size; it arrives as soon as there is any open water, and remains so long as there is a hole in the ice big enough to hold it; in 1884, first seen April 16 (Nash). Breeding more commonly than the precelling (1881) (Macoun). Carberry: Abundant summer resident; ureeding; Brandon, Souris Plain, soutlı slope of Riding Mountain (Thompson). Shell River: 1885 , first seen, two pair, on May 1 ; afterwards seen every day ; it is common all summer and breeds here (Calcutt). Qu'Appelle: Common summer resident; breeds; arrives April 20 (Guerusey). Savern Honse (Murray).

36. Aythya collaris. Ring-necked Duck. Marsh Blue-bill.

Tolerably common summer resident. Winnipeg : Summer resident : common (Hine). Swamp Island: 1885 , first seen, six, on May 9; next seen, the hulk, on May 10; tolerably common; breeds here (Plunkett). Breeding in the marshes of Waterhen River, 1881 (Macoun). Portage la Prairie: Common summer resident; frequently confounded with the lnst, and they are both frequently more than confounded by persons who shoot them, for if there is ouly one kick left in them when they drop they will utilize that to such good purpose that they will get under corer beneath the water, where they conceal tliemselres so well that it is almost useless to try to retrieve them (Nash). Qu'Appelle: Cor mon summer resident; breeds; arrives April 20 (Guernsey).

37. Glauolonetta clangula amerioana. American Golden-eje. Whistler. Tree Dnck.

Rare summer resilent. Winnipeg : Summer resident; tolerably com. mon (Hine). Red River Valley: Summer resilent; tolerably common; I have taken twenty-one eggs out of one nest in an old oak tree at Shoal Lake, near Winnipeg (Hunter). Swampy Island: 1885, first seen, six, on May 5 ; next seen on May 6 ; became common May 8; is

toleral

or Tree

Prairie in the less all of Apr Septem breed $i$ snmme south, (Thom] a trans ing (Ca arrives

I sho in the 8 at the I (Hine).

Comr with tr along $t$ 25 (Dav Island : 22; las 1886, fi 19 (Plur few rem found prairio in poni Carber Duck I first see and br breeds : Station 
tumn, prinkes, seldon ntil it is fro-

e: Common lesser Blue-

11.

Winnipeg : nt, chiefly in I: 1885 , first common; is 5 ; bulk ar. 37 (Christy). ig on all the is any open g enough to re commonly ant summer e of Riding pair, on May l breeds here eds ; arrives

bill.

ner resident ; May 9 ; next re (Plunkett). n). Portage hded with the d by persons hen they drop ill get nncler o well that it ppelle : Cor ey).

tler. Tree Duck. tolerably com. hbly common ; 1 oak tree it d : 1885 , first hon May 8; is tolerably eommon, anil breels here (Plunkett). "Common Golden.eye or Tree Duck ;" alsu breeds near Norway House (Bell, 1880). Portage la Prairie : Rare; summer resident; comes late and leaves early ; is scarce in the shooting season ; shot one in August, and as I see them more or less all summer, I assume that they breed here; arrives about the encl of April and departs early; I have rarely seen. one after the 1st of September; first seen April 27, 1885, April 20, 1836 (Nash). A few breed in the Waterhen River marshes (Macoun). Carberry : Very rare; summer resident; Jume 23, 1883; at a sinall lake in the woods to the south, to-day, I saw a Whistler, and I think the species breeds here (Thompson). Shell River: 1885, first seen, one, a ale, on April 25 ; a transient visitor, passing north and not remaining any time or breel. ing (Caleutt). Qu'Appelle : Tolerably common summer resilent; breeds ; arrives April 15 (Guernsey).

\section{Glaucionetta Islandica. Barrow's Golden-eye.}

I shot a brace at Lake Manitoba in 1879, and a drake at Shoal Lake in the spring of the following year; and I saw a drake which was killed at the mouth of the Red River (Hunter). Winnipeg: Rare; straggler (Hine).

\section{Charitonetta albeola. Buflle-Leat.}

Common summer resident; breeding in cleep ponds that are fringed with trees; among the eommonest speeies after the fall inigration, along the boundary (Cones). Dnfferin: Arrived between April 20 and 25 (Dawson). Winuipeg: Transient visitor; abundant (Hine). Swamp Island : 1835, first seen, about twenty, on May 21 ; next seen on May 22 ; last seen, May 25 ; is common ill migration but does not breel; 1886, first seen, six, on May 10 ; bulk arrived May 13 ; last seen, May 10(Plunkett). Portage la Prairie: Abundant in spring and autumn, some few remaining to breed; at Lake Champique, near Hedingly, I onee found young, unable to fly, on the 15th of August; they were on a prairie slough, at least three miles from any trees (Nat '1). Abundant in ponds in the autumn; not seen in the prairie regions (Maeoun). Carberry : Common summer resident; breeding also at west slope of Duek Mountain, Portage la Prairie (Thompson). Shell River: 1885, first seen, two, on April 27 ; vext seen, May 20; is common all summer and breels liere (Calcutt). Qu'Appelle : Common summer resident; breeds; arrives September 20 (Guernsey). 'Severn Honso; Trout Lake Station (Murray).

40. Clangula hyemalis. Old sqquaw. Swnllow-tailed Duck. Coween.

Severn Kouse (Murray), and cluring winter found in many purts of the Mississippi valley (Cook), therefore probably Manitoban. 
41. Eistrionious histrionious. Harlequin Duck.

This bird will probably be fonnd in Manitoba, as it has been recorded from near Hudson's Bay (Hutchins). Breeds in British America; * * throughout Illinois in winter, and has been taken at St. Louis, Missouri (Cooke). Breeding in the Rocky Mountains, near the boundary (Cones).

Pow is tlc ou sheep; two specimens, both drakes, otc. ** * These birils are fouucl in small rivulets, seldom in large rivers, abont 90 miles inland. They migrate to the sonthward with tho reese; feed on grass and suall worms at the botcoun of the creeks; have a whistling note; they build their nests in thi grass, and lay ten or more eggs, resembling those of a pigeon in size aud color. The name in the Algonquin lauguage implies a species of dncks that frequent the waterfalls or cataracts. The young brood are very prettily speckled. (Hutchins MSS. Obs. H. Bay, 1782.)

42. Oidemia americana. American Black Scoter.

Rare; migrant. Wiunipeg: Transient visitor; rare (Hine). Swampy Island: "Black Duck," 1885, first seen, four, on May 19; next and last seen on May 20 ; is rare here and does not breed (Plunkett). Trout Lake (Murray).

43. Oidemia deglandi. White-winged Scoter.

Rare; migrant; possibly breeding. Wimnipeg: Summer resident; tolerably common; Lake Wiunipeg (Hine). Red River Valley: Transient visitor; tolerably common on rocky localities (Hunter). Occurs between Hndson's Bay and Lake Wiunipeg (Murray). Near Russell, Júly 6, 1882 ; Bitter Lake, Washi ngton, sliot a velvet scoter, female; leugth 20 , extension 36 ; nll over dusky ; bill gray ; a light patch near bill and one behind eye; secondaries white; legs dull reddish; apparently breeding (Thompsou). Qu'Appeile: Common; migrant; May 1 (Guerusey). Trout Lake Station; Serern House (Murray).

44. Oiāemia perspicillata. Surf Duck or Surf Scoter.

Uncommon; migrant; common at Lake Winnipeg (Hine). Qu'Ap. pelle: Rare migrant; May 1 (Guerusey). Red River Valley : Tolerably common; transient visitor; abundant (Hunter). A specimen from Nelson River in the Smithsonlan Iustitution (Blakiston).

45. Erismatura rubida. Ruddy Duck.

Summer resident; breeding; common and breeding in suitable places throughout the region aloug the boundary; at Turtle Mountain nesting in numbers in tho pools (Cones). Winnipeg: At fow are seen each year abont Long Lake when it breeds; also Lake Winnipeg, and at Shoal Lake (Hine). The Ruddy Duek is sometimes found in swamps near the Red River, but they are more numerous nt Shoal Lake and Mani. toba (D. Gunn). Portnge la Prairie: Shot a female here September 10, 1884; she was with two buftle-heads at the time (Nash). Seen at 
Tonchwood Hills in September, jut not in Manituba (Macoun). Shell River: 1885, first seen, one male, on May 23 ; breeds here; flaps for a few yards on the water and spreads its tail and shakes its head like a fan-tail pigeon (Calcutt). Qu'Appelle: Common summer resident; breeds May 1 (Guernsey).

\section{Chen cærulescens. Blne Goose.}

Winnipeg : Rare; transient visitant (Hine).

47. Chen hyperborea. Snow Goose; Whito Wary.

Abundant spring migrant; less common in the fall; abundant dur. ing migration along the boundary (Cones). Winnipeg: Transient risitor; abundant; going north to breed (Hine). Red River Valley : Transient visitor; abunlant (Hunter). Swampy Island: 1885, first seen, four, on May 7; next seen on May 10, after which it disappeared ; never common; does not breed, and is rare on this lake (Plunkett). Migrant at Shoal Lake ((iunn). Ossowa (Wagner). Portage la Prairie: 1884, abunlant spring visitor to the large grass marshes near Portage la Prairie, but rarely seen in the autumn in that neighborhool ; near Winnipey it is, however, not uncommon in October; first seen April 23, 1884 (Nash). Carberry : Seen in enormous numbers in spring, and in much less numbers in the fall (Thompson). Little Saskitchewan, near St. Martin's Lake: Wavies, as the lialf-breeds term them (Wa-wain Cree) (Anser hyperboreus), flying to the south early this morning in large flocks, were regarded as a sure sign of approach. ing winter (Sept. 27, 1858, Hind). 'Two Rivers: 1885, first seen, one, on A pril 6; next seen, four, on April 18; migrant (Uriddle). Qu'Appelle: Transient; passing over May 3 to 28 (Guernsey). Severn Houce (Mur. riy).

In Hudeon's Bay they are the shyest and most watchful of all the species of geese, never suffering an open npproach, not oven within two or three gunshots. Yet in some of the rivers near Cumberland House and at Basqniau the Indians frequently kill twenty at one shot; but this is only dowe in moonlight nights, when the geese are sitting on the mul and the sportsmen are perfectly concenled from their viow. (Hearne, 1795.)

In April the dueks and geese return in grent unmbers, becone plentiful, and feed in unmerons flocks in ull the marshes fringing the lnkes for at loast a month and a lanlf. The gray geese mul ducks draw off by degrees in May, but the white geese (winee) eome genernlly in the last woek of A pril, unl hegin to elear awny for IItulson's Bay on the 13th or 14th of May, where they invariahly arrive on the 15th of Xay. The last of them leave here from the 20th to the 25th of the same month. (D. Gunn.)

These birls pass over the country in eonntless numbers each spring, geverully ar. riving in large bands ahout the 15th of May, although I have seen stragglers as early as the 28th of April. A great number of immonse tlocks generaliy remain in the Province for a conple of weeks to " take in saml" aml feetl. They are very easily sliot while on the gravel gronnds: they uppear very stupis (i. e., in the morning and evening). When not taking in sanl anil gravol they are very diffeult to npprench and are as wary as any geese. These birds are rarely seen in the autumn. The alf-

recorded Tolerably

ident; tol-
y : Tran-

c Russell, r, female ; A ; appar. ble places in nesting each year at Shoal s near the nd Maniember 10, Seen at

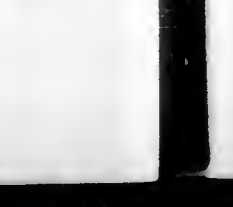


breeds say that they do not pass over Manitoba on their return, but take a more western course. Although I have spent two weeks every October for the past 15 jears in shooting, I have never seen more than an occasional flock of perhaps fifty birds in the antumn. (Hunter, in MSS.)

48. Anser alblfrons gambeli. American White-fronted Goose. Langhing Goose. Specklebelly.

Winnipeg: Migrant; transient visitor, rare (Hine). Anser frontalis of Baird from Red River Settlement (Blakiston). Ossowa : Migraut; May 11 (Wagner). Shell River, 1885, first seen, eighteen, on April 10; a transient risilor, passing north and not breeding or remaining any time (Oalcutt). Near Long River, May 19, 1882, O. T. shot a pair of White-fronted Geese, hut secured only the male; length, 27 $\frac{1}{2}$; extension, 58 ; testes but little developed; gizzard full of young shoots of aquatic plants; a peculiar wart or excrescence grew on the tibio-tarsal joint. No others of the species were seen (Thoinpsou). Near Cumberland House and Basquian they are found in such numbers that the Indians in moonlight nights frequently kill upwards of twenty at a shot (Hearne, 1795).

\section{Branta canadensis. Cauada Goose. Will Goose. Wavy.}

Abundant; migrant; a few breed; common at boundary along Mouse Rirer in late September (Ooues). Winuipeg: Sumwer resident; abun. dunt; a few breea (Hine). Red River Settlement: April 2, 1856, April 1, 1858 (Blakiston). Red River Valley: Abunduut in migration; a few breed (Hunter). Breedıng on Lake Winnipeg in June (Kennicott). Swamp Island, 1885: First seen, eighteen, on April 14; uext seen April 15, when it became common; breeds here; in fall; last seen Septem. ber 23, 1886; first seen, four, on April 8; bulk arrived April 16 (Plunkett). Ossowa: Common; breeding, 1835; last seen, fifteeu, on November 28 (Wagner). Oak Point, 1885, April 7 (Small). Portage la Prairie: Uommon in spring and fall; a few breed in the marshes near Lake Manitoba; arrives about the middle of April or betore should there be open water; departs when all th. lakes and rivers are frozen over, usually about the 10th of November (Nash). In 1879, breeding on the Assiniboine, whers Brandou now is; also above the rapids (Macoun). Two Rivers, 1885 : Great flight April 1; next April 3; common in spring and fall (Oriddle). Brandon: Two young taken on the river August 25, 1882 (Wood). Dalton, 1889 : First seen, about fifteen, on March 21; next seen on Mareh 22; became common on March 26; was last seen May 10 ; rarely breeds here (Yoemans). Shell Kiver, 1885: First seen, fifteen, on April 9; afterwards seen nearly every lay in the migrating seasou; old pairs breed near here (Oalcutt). Qu'Appelle: Common summer resident; breeds April 1 to 10 (Guernsey). Oarberry : Abuudant in migration; rarely breeding south of Souris River; migrant; breeding near Shoal Lake, west (Thompson). 
take a more past 15 years fifty birds in

ghing Goose.

er frontalis Migraut; 1 April 10; aining any t a pair of extension, of aquatic arsal joint. umberland he Indians at a shot

Vy.

long Mouse ent; abun. 1856, April igration; a Kennicott). seen April on Septem. il 16 (Plun. ell, on NoPortage la arshes near tore should 8 are frozen 9, breeding rapids (Ma3 ; common on the river flfteen, on ch 26 ; was eiver, 1885: - day in the a' Appelle: Oarbelry : River; mi-

On October 4, 1883, near Shoal Lake, west, I chanced to call at the home of Mr. McMillan, a farmer. There was a flock of six full-grown tame Canadian Geese feeding about the door. Mrs. MIcMillan informed me that in the spring they found the old goose nesting in the slough near by. The bird was shot, and her seren eggs brought into the house and laid by the stove curing the daytime, and at night they were wrapped in flannel and put away. At length they began to hatch. The good wifo assisted six of the goslings into the world, but, fearing she had done wrong, allowed No. 7 to work his own passage. The six lived and throve, while No. 7 died. (In the spring of 1834 she still had" the brood of swan-like birds; they were living in the barnyard in a state of perfect domestication.) The fact that these eggs must hare been chilled nightly, and in the daytime exposed to a dry, unnatural heat, shows the wonderful vitality possessed by wild eggs.

Another farmer, living near Uarberry, added some geese to his barnyard in the same way, but, I believe, they did not breed in confinement.

49a. Branta canadenats hutchingil. Hutchins's Goose.

In September a very small young bird, taken on Red River by Robert Kennicott (Bairl). Portage la Prairie: Common in spring and fall only; have not been able to discorer that it breeds near here (Nash).

\section{Branta bernicla. Brant.}

Migrant; observed ouly during the migration along the boundary (Cones). Winnipeg: Transient visitor (Hine). Red River Valley: Transient visitor; I hare taken it at Shoal Lake (Hunter). Carberry: Observed as a migrant; not common; no specimen taken (Thompson).

\section{Olor oolumblanus. Whistling Swan.}

Occasional about the large lakes; not demonstrated to breed. Winnipeg: Transient visitor; rare (Hind). Oak Point, 1884: Arrived May 4 (Small). Always seen in flocks high up (Macoun). Portage la Prairie: In the autumn of 1886 saw one that had been shot on Lake Manitola, and in previous years have seen this or the next species there msself (Nash).

Some years ago, when I built Cumberland House, the Indians killed those birds (swans) in such numbers that the clowu and quills might bavo been procured in considerable quantities at a trifling expense. (Hearue, 1769-1772.)

\section{Olor buooluator. Trumpeter Swan.}

Rare migrant; observed ou a few occasions in Dakota late in Sep. tember and in the first half of October during the migration; said to breed in Minnesota (Coues). Wiunipeg: Transient visitor; rare (Hine). Swamp Island, 1886, first seen, eight, on May 1; bulk arrived May 6 ; last seen May 10 ; tolerably common this year (Plunkett). ' Portage la 
Prairie: Occasionally seen in spring and autumn, I am informed, but as I never actually identifed the bird myself $I$ am not positive about it (Nash).

\section{Botaurus lentiginosus. American Bittern.}

Common summer resident in all extensive marshes; apparently rather common on Mouse River, at the boundary, in September (Coues). Dufferin : Arrives between April 25 and 30 (Dawson). Morris : Often seen April 29, 1887 (Christy). Winnepeg: Summer resident; abundant (Hine). A specimen in Smithsonian Institution, from Nelson river (Blak. iston). Ossowa : Breeds (Wagner). Oak Point: 1884, arrived May 1j (Small). Portage la Prairie : Common summer resicuent; first seen May 17, 1884; May 22, 1885; April 19, 1886; last seen October 16, 1884 (Nash). Abundant in all marshes throughout the country; shot June 11, 1881 (Macoun). South slope of Riding Mountain, on Little Saskat. chewan, August 28, 1858; in the marshes, herons, cranes, and bitterns were distributed in groups (Hind). Carberry: Coumon; southern slope of Riding Mountain, abundant; Portage la Prairie; Sewell; Fort Ellice; Rat Portage, 1886 (Thompson). Shell river 1885, first seen, one on Mas 4, afterwards seen every day; is common all summer and breeds here (Calcutt). Qu'Appelle: Cominon summer reside'it; breeds ; arrives May 21 (Guernsey). Severn House (Murray).

On May 23, 1884, at Sewell Plain, heard a bittern pumping in the slough after dark; the sonud has been very aptly likened to the syllables "pump-o.ga;" the first two notes are like the stroke of a pump, the 'ast is exactly like the swish and gurgle of water in a deep pipe. This sound is not at all ventriloquial, as is that of the European Bittern according to many accounts, and I had no difficulty in following and flushing the bircl, but it was too dark to shoot, as I could only see the dim form against the sky when it rose after flying, apparently 50 yards, and pres. ently he was heard again working his pump in the distance.

On June 2, on the south slope of the Riding Mauntain, I was led to a bittern, after sundown, by its pumping; I watched it catching insects until dark, and then shot it, and found in its stomach a most miscellaneous collection of insects, etc. Same day, near the Fingerboard, I traced a bittern by his note in theevening, and shot him; of adult; stom. ach contained crawfish, insects, a garter-snake, a mouse, and a meno. branchus.

Jume 3, at Rapid City Trail, south slope of Riding Mountain. The bittern is one of the commonest of the large birls that are to be found in this region. Its long brown form on flagging wing, with beak pointed one way and legs another, is to be seen tying over nearly every exten. sire slough of this region. Suddenly, in the midst of his flight, he may he seen to dangle his legs, "reverse action" his wings, and drop into the inarsh. There, for a moment, he stands, not deigning to notice the blackbirds that are trying to terrify him into a retreat, bis long neck

straight right, b is tucke the head structur

In tak witlin $\mathbf{r}$ the rush collect t natural already ard, sun and to that ma sundry but will of all th

I havi long dor thing. owl hu sand, or and con stitring going $\mathrm{n}$

Contral its; quitt along the cover at : liend and vertical, it so clos Bitterus : beard the

Accid mell in

Unco resiclen Assinib to Peml nipeg: Summe 
formed, but itive about

ently rather nes). Duf. Often seen abundant river (Blak. ved May 15 st seen May er 16, 1884 shot June ttle Saskat. nd bitterns thern slope Fort Ellice; en, one on and breeds zds; arrives

ping in the he syllables np, the 'ast This sound n according dushing the e dim form $\mathrm{s}$, and pres.

was led to a ing insects st miscellagerboard, I dult; stom. und a meno-

ntain. The to be found sak pointed very exten. ht, he may d drop into notice the s long neck straight up at full length. Then, having satisfied himself that all is right, he touches a hidden spring, and instantly the preposterous neck is tucked away somewhere in a surprising way, and so effectually that the head looks as though stuck on the shoulders without any intervening structure at all.

In taking its prey the bird either waits until the rash victim comes within reach of its spear-like bill or goes stalking about after it among the rushes. Its food is of such a varied character that one only has to collect the stomachs of about a score of bitterns to have un extensive uatural history inuseum. The specimen taken yesterday contained, as already stated, a garter-snake, a mouse, an amblystoma or water lizard, sundry crawfish, and an innumerable company of various insects; and to this list may safely be added every kind of small animalism that may be secured about the marshy home of the bird. Misled by sundry printed statements, I once cooked an individual of this species, but will not be so misled any more. It is sufficient to say that it tasted of all the creatures it feeds on.

I have somewhere read that this birl is strictly diurnal. This I have long doubted. Indeed, I begin to doubt that any bird is strictly any. thing. When we find a liawk gorging itself with choke cherries, a nightowl hunting by sunlight, and sandpipers that never pipe or go near sand, one is prepared to give up, on behalf of the birds, all rules of life and conduct, and expect the strictly "diurnal" bittern to be up and stirring during the hours of darkness and gloom, as, indeed, the foregoing uotes lead me to suspect he does.

Contrary to tba nsually expressed opinion, this bird is strictly diurnal in its habits; quitting its resting places in the reedy bogs early in the morning, feeding out along the margins of ponds, streams, etc., during the day, and returning to its close cover at night. When alarmed, the bittern, instead of rising, frequently erects its hend and neck and depresses its tail between its legs, until the whole body is almost vertical, and so stands perfectly still until the danger is past; when in this position it so closely resembles a dead branch that it requires a practiced eye to detect it. Bitterus are most frequently heard to boom or pump in the spring, but I have also beard them all through the summer; the latest date being in August. (Nash.)

\section{Botaurus exilis. Least Bittern.}

Accidental visitant. Winnipeg: Summer resident: only one specimen in 10 years in Manitoba (Hiue).

\section{Ardea herodias. Great Blue Heron.}

Uncommon summer resident, of erratic distribution; common summer resident in all Red River Valley; not noted by me any'where in the Assiniboine region; observed during our passage down the Red River to Pembina (Coues). Pennawa River, September, 1887 (Hind). Winnipeg: Summer resident; tolerably rare (Hine). Red River Valley : Summer resident; common at Shoal Lake, township 16, range 3, enst 
(Hunter). Portage la Prairie: 1884; rare; summer resident (Nash). South slope of Riding Mountain, on Little Saskatchewan River: In the unarshes herons, cranes, and bitterns were disturbed in groups (Bind). Occasionally seen, but not very common; shot on Swan River, April 28, 1881; not observed breeding (Macoun). Breeding in numbers on Rid. ing Mountain (Green). Qu'Appelle: Tolerably common; summer resident; breeds ; arrives May 6 (Guernsey).

My enmmer of 1880 was spent in the Northwest Territory of the Dominion. The 20th of July last found me in the Duck or Riding Mountain, at the head waters of Bird's Tail Creek, about $51^{\circ}$ north, aud on the one hundred and first meridinu. These mouutaius are covered with a dense forest of tall poplars and birch aul thick underbrush of hazel aud raspberry, making it impossible to got through without cutting a trail in advance. This 20 th of July was a very hot day. We had started at 6 a.ni, with a train of thirteen heavily loaled carts, and by $11 \mathrm{a} . \mathrm{m}$. had male abont 3 miles, when a very peculiar noise saluted our ears. Knowing this forest to bo full of benrs, we at once came to the conclusion that we were in the vicinity of a family (sisters, consins, and aunts) of those affectionate creatures. The train was ordered to halt while the chief of the party uud myself went forward to prospect. As we ulvanced the noise grew louder and louder, till we called a council of two to decide what had better be done-face the enemy or draw on onr reserves and advance in full force. While deliberating, the ohief happened to cast his eyes heavenwards and the mystery was explained. We had struck a heronry; hundreds of these birds were passing to and fro; and on going forward a hundred yards or so we found the tops of the poplars covered with their nests, the young birds, ful' grown but not able to fly, perched on the highest branches of the trees. Here in the heart of a dense forest, probably never trodden by man before, were thousande of neste of our common Blue Heron (Ardea herodias Linn.) We cut down several trees and captured the young, which were cooked and eaten by some of our men with relish, probably because it was the first fresh food for three months. The nests were made of the emall dead branches of the poplar and were placerl as near the tops of the trees as possible. I kept two of the young birds alive for a few days, when, becoming able to fly, they took their depsiture.

These mountains are full of small ponde and bottomles: marshes, which owarm with lizards and emall fish, on which the herons feed, and or s. :ting to an open space near the herony we could see tho old birds coming and going in every directiou. Those coming home were stuffel to the bill with food for their young, making then present a very ungainly figure, as they lazily flopped their way towards the woods. On pushing our way throngh this mountain forest, we discovered three good-sized lakes, about one-half mile wide, and from 1 to 2 miles in length each. We tried them for fish, but only caught a few common chub.

\section{Ardea virescens. Green Heron.}

Rather common in the Assiniboine, near the mouth of Shell Rirer, September 25,1881 . This was certainly a heron, and was certainly not tiee Night Heron, as it was much sinaller; it had no plumes, aud was green on the wing shoulders; there were at least a dozen of them; they were in the trees along the river, not far from Mr. Henry Deumark's house (Macoun). Taken them at Shoal Lake, near Winnipeg, and an told that thes breed in the sloughs around Turtle Mountains; they are rare compared with the number of Blué Herons (R. H. Hunter). 
nt (Nash). ver: In the ups (Bind). r, April 28, rs on Ridmmer resi-

on. The 20th of Bird's Tail These mouuk underbrush tiug a trail in b a.m. with a 3 miles, when f bears, we at ters, cousins, to halt while ulvanced the wat had bet. in full force. d the mystery re passing to of of the popto fly, perched est, probably a Blue Heron young, which ase it wus the ead branches

- I kept two hey took their

which owarm an open space ery directiou. making them ds the woods. reo good-sized h. We tried

Shell Rirer, ertainly not es, aud was them; they - Denmark's peg, and am us; they are ater).
57. Nycticorax nycticorax navius. Bluck.crownell Night Heron.

A somewhat common summer resident in Red River Valley; one individual seen during our passage down Red River to Pembina (Coues). Winnipeg: Summer resident, tolerably conmon, especially about Reaburn Marsh in August a:nd September (Hine). In great numbers at Shoal Lake, nesting among the reeds (D. Gunn). Red River Valley: Summer resident; common (Hunter). I have seen several specimens that were taken near the southeast end of Lake Mauitoba; have never seen any on the Big Plain (Thompson). Shell River: 1835, first seen, one, on May 16; a truusient visitant; not breeding here (Calcutt). I nerer met with it in six years of observing near the Red and Assini. boine Rivers (Nash).

I may here observe that great numbers of Night Herons breed here. They fix their luests to the reeds 8 or 9 inches above the water and deposit in each 4 or 5 roundish blue eggs. I think this is the only pluce in Rupert's Land where this species is found. We gave them the "go-by" last sumener. The Indians call then Kitcho geskmun, $i$. e., big kiug.fisher. (D. Guun.)

58. Grus americaua. Whooping Crane. Flying Sheep.

Tolerably com non migrant and rare summer resident; frequent in Mouse River country in August, September, and October (Coues). Winuipeg: Summer resident; tolerably common (Hine). Oak Point: 1884, arrived May 1, 1885 ; first seen, three, on April 15; next seen on April 17; iscommon and breeds here(Small). Rare summer resident near Westbourne, arriving in April ; seen all summer (Nash). Carberry : In migrations only ; rare ; have seen specimens from Shoal Lake, where it is saicl to breed (Thompson). Breeding in the marshes between Moose Mountaiu and the Pipestone (Macoun). Shell River: 1885, first seen, two, on April 30 ; next seen, a pair, on May 3 ; a transieut visitant, passing north aud not breeding (Calcutt). White Sand Kiver (Cluristy). Qu'Apuelle: 'Tran:sient, passing over; April 28 to May 1 (Guerusey).

On April 19, 1882, saw two Whooping Cranes; the residents call them "Flying Sheep." They flew at a great height aud were loudly croaking.

This beautiful bird is common in the Qu'Appelle Valley and in tho Touchwood Hill range. It is a dangerous antagonist whon wounded, striking with unerring aim und great force with its powerful 2ill. When the bird is wonnded, the best way to avoid its attacks is to present the muzzle of the gun as it approaches; it will fix its bill in the barrel, and mny then be destroyed without dauger. Instances have been known of this bird clriving its bill deep into tho bowels of a hunter when not successful in warding off its blow. (Hine.)

\section{Grus mexicana. Sandhill Crane.}

Tolerably common summer resident; common along the boundary after leaving Pembina; breeding (Coues). Winnipeg: Summer resident; tolerably counmon (Hine). Dufferin : Arrives between April 25 
and 30 (Dawson). Swamp Island: 1885, first seen, one, on June 10; rare and does not breed here; in fall, last seen September 7 ; 1886, first seen, two, ou May 1; bulk arrived May 3 (Plunkett). Norway House (Bell, 1880). Oak Point: 1884, arriced April 19, 1885; first seen, two, on April 15; next seen on April 16; is common and breeds here (Small). Portage la Prairie: Tolerably common summer resident; breeds near here; arrives in A pril ; first seen in 1884, April 21 (Nash). Uarberry : Common; in migration, a few breed ; also at Fingerboard, Shoal Lake, west, and Russell (Thompson). Assiniboine, near the White Sand, and at the month of the Shell, 1881; also, saw young ones near Moose Mountain, June, 1880 (Macoun). Two Rivers: 1885, first seen, two, on April 16; next seen, one, on April 19; became common April 23; is pretty common here and breeds (Criddle). Dalton : 1889, first seen, one, on April 12; next seen on April 13, when it became common (Youmans). Shell River : 1885, first seen, tro, on April 19; seen every day afterwards; is common all summer and breeds here (Ualcutt). White Sand River in May (Christy). Qu'Appelle: Tran. sient; passing over, April 28 to May 1 (Guernsey). Trout Lake Station (Muray).

The first intimation that we usually have of the advent of the crane is the loud trumpeting or croaking that seems to shake the air for miles. But soon we begin to see the birds themsel ves, usually in pairs, even at this early season. Their food now is ehiefly rosepips, and as they stalk over the bare plains gathering this manna of the feathered race, ample opportunity is offered for observation. At first one sees little to note beyoul their excessive wariness, but as the wurmer weather quickens their feeling, these majestic stalkers, these stately trumpeters, may often be seen so far forgetting their dignity as to wheel abont and dance, flapping their wings azd slouting as they "honor their partners," and in various ways contrive to exhibit an extraordinary combination of awkwardness und agility. This dance is no doubt one of the courting manenvers, for I have observed it only during the pairing season.

It has been asked if these eranes breed in communities. To this I reply, I never saw anything to lead me to such a conclusion; ail cases of their nesting that have come under my notice were those of isolated puirs.

- The localities they seleet are generally damp meadows, not necessarily near the sand hills, the chiefly lesired surrounclings being rauk gras.s wherein to forage, and serubby or undulating land for cover.

When ilrst they enter the wille world the two or three young ones are providerl with a coat of redilish yeliow down und an apparently superfluous lengtli of limb. I perceive by reference to muthorities, that the cranes are "priecoces," which being interpreted meanoth " they ure elothed and eni run and feed themselves us soon as hintehed." Not having seen the young cranes at this interesting period, I can not gain. say the above statement; but know that a young cue taken at the end

of June, rralking to which came on to monor later on tively lik uttering croaks of lerity of his lieels

I took elegant 1 in gool 1 of the al fall once in a most became ? wherein a Swaius liave stre I found 0 a sparro pimned it and agai lowed it. and insec they will

How it I found at once $r$ eaten my

Sever: almost a to keep duriug $t$ trouble $\mathrm{t}$ Whace the and the sportsing men wei surpasse trìlge. gumo lav itself thi The y 
, on June 10; mber 7 ; 1886, tt). Norway 9,1885 ; first in and breeds imer resident; oril 21 (Nash). Fingerboard, ine, near the w young ones rs : 1885 , first same common Dalton : $\mathbf{1 8 8 9}$, en it beeame , on April 19; 1 breeds here pleelle: Trant Lake Station

t of the crane e air for miles. pairs, even at I as they stalk ed race, ample 3 little to note ther quickens unpeters, may ont and dance. partners," and ombination of if the courting ig season.

ies. To this I sion ; ail cases ose of isolated

not necessarily ug rauk grass over.

ee young ones an apparent] ithorities, that leth " they are intched." Not I ean not gain. ken at the enil of June, and evidently 2 or 3 weeks old, made such a poor attempt at walking that he reflected but little credit on the noble order of precoces to which his family belongs. And yet I must almit that when I first came on him he ran with very fair speed, and as his parents contrived to monopolize my attention for a time he escaped into the serub, but later on was found squatting as still as death. He looked then decep. tively like a red rabbit or a small fox. On being touched he sprang up uttering a gentle "peeping" which contrasted strangely with the strong croaks of his parents. He ran for a few yarls with the grace and celerity of a Cochin fowl, but soon weakened and was obliged to sit on his heels.

I took him home and found that be spent fully half his time in this elegant position, and that, moreover, although be ate well and seemed in good health, he was scarcely able to stancl erect excepting in the heat of the day, and when be attempted to rise he was almost sure to fall once or twice through his neck getting entangled with his shanks in a most unprecocial manner; nevertheless, he grew and fletged and became quite tame. Thun eame two other pets to share the building wherein he had so long dwelt alone; they were a Peregrine Falcon and a Swainson's Buzzarl. For a time all went well; the crane seemed to have strength enough and beak enongh to take cure of himself. Then I founcl out that he would even share the Falcon's food, so I offered him a sparrow; he seized it savagely and, uttering a peculiar harsh note, pinned it to the ground with his bayonet-like bill, then stabbed it again and again, aud at last, having reduced it to a shapeless mass, he swal. lowed it. So that, although I lave found only berries, grain, grnss, and insects in the gizzards of old ones so far, I think it is likely that they will also eat frogs, mice, or small birds.

How it came about I never could tell, but one morning after a storm I found the peregriue sitting on the dend boly of the crune; I did not at once remove it, and when I came again the two baudits bad nearly eaten my gentle pet.

Several of the neighbors also have triel to rear young cranes and almost always with success and satisfaction, for, although it is difficult to keep them over winter, they become so tume mud are so interesting luring their stay that their owners feel amply rewarded for what little trouble they have taken with them. As a game bircl I am inclined to place tle present species first on the Manitoban list, as the White Crane and the swans are too rare for insertion on a list of species that the sportsman mny pursue with regularity nud suecess. Air average specimen weighs about 0 of or 10 pounds, and the quality of the thesh is 111 . surpassed by that of my of our ordinary birds unless it be the par. trilge. I should strongly alvocate the protection of this bird by the game law wers it not that it is so thoroughly well able to take care of itself that legislation in its favor seems altogether unnecessary.

The young cranes are apparently strong on the wing in August, for 
at this time small bands of the species may be seen sailing high over the prairie, apparently strengthening their wings before they are com. pelled to journey southward for the season. As September draws nigh their numbers are increased, and the long array of the grand birds present a most imposing spectacle as in serpentine lines they float away after the sun.

\section{Rallus elegans. King Rail.}

Mr. Hine claims to have seen this near Winnipeg. At Carberry I once got a flying glimpse of what I took for this bird, hut it was 30 yards awas, and I failed to get either a secon' glimpse or a shot at it (Thompson).

61. Rallus vi-jinianus. Virginia Rail.

Winnipeg : Common summer resiclent (Hine). Nest found at Carberry (Thompson).

The fine spreimen of this bird in Manitoba Vusenm, taken at Reaburn, where, Mr. Hine says, it is plentiful. It is, no lonbt, more common in this country than is generally supposel; for, as Dr. Coues remarks, "their habit of skulking and hiding in the most inaccessible places they frequent, renders them difficult of observation, and they are usually considered rarer than they really are." The call of this

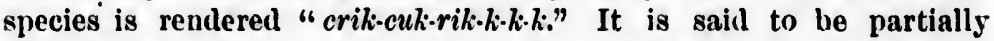
nocturnal.

A nest was brought to me from a slough near Carberry, July 30, 1884. It was found in a tussock of coarse grass, and was built of dry stems of the sume; the eggs, eight in number, were quite fresh, and differed from those of the Carolina Rail only in being of a lighter color, and with reddish instead of umber spots, and chiefly about the large end; oue was 14 by to, the others similar. The nest was of ri: 'es and built precisely like that of the Carolina bird, bnt it was situated rather in a lamp meadow than in a mersh. I did not see the bird, but have little loubt that it was the present species.

Mr. Nash sends the following note: "It haunts low ground like the rest of the orde; but, so far as I hare seen, they never go into deep. water marshes; in fact, they keep where there are bushes and low trees-alders, willows, and the like; and, when flushed, Insteal of taking to the rushes, they in rariably tly in amongst the bushes."

\section{Porzana oarolina. Sora. Common Rail.}

Common summer resilent of all marsbes. In September along Mouse River, at the bounclary, appeared to be rather cammon (Cones). Win. nipeg: Summer resident; abundant (Hlue). Rel River(Brewer). York Factory (Bell). Portnge la Pruirie: Very abundant summer resident; arrives abont the mldklle of May ; ieaves about the end of September (Nash). Oarberry : Abundant summer: resident; breeding; and in the

country

in Duck

seen, $t w$ eutt). $\quad \mathrm{s}$

Tnne 2

Sora. I

being ha from the were pla across. indefatig clutch u

Late in flight, tho travels to be found i lare been

Summ (Hine). near For fly and d there is 8 censis I o

On Ap by the sl that see describer have bee

(SInce driver, joroduced toban ms Yellow 1 steel, I a

On Au I put it, was alre As soon ill.treate suw the in her es Both fle The rail his beak 
high over $y$ are com. lraws nigh birds pretloat away

Carberry I it was 30 a shot at

and at Car-

en at Reamore com. Dr. Coues naccessible , and they eall ol' this e partially

als $30,1884$. f dry stems and differed color, and large end ; es anil built rather in a jhave little

Ind llke the , into deep. es and low insteal of ishess."

long Mouse mes). Winwer). York er resident; i Beptember ; and in the

country from Fingerboard to Birtle, nesting ; rery abundant; breeding in Duck Mountain, June, 1884 (Thompson). Shell River: 1885, first seen, two, on May 12; is eommon all summer and breeds here (Calcutt). Severn House (Murray).

June 28, 1882, at Rapid City Trail near Fingerboard, fonnd the nest of a Sora. It contained fourteen eggs, which were-within a few dass of being hatched. The nest was placed in a bed of rushes, about 10 feet from the water, and was built of dry stalks of reeds, etc. The eggs were placed in two tiers, one on the other, as the nest was but 4 inches across. The question naturally suggests itself, however, how does this indefatigable little ovipositor contrive to warm the whole of this large clutch under her own little bosom and wings?

Late in tlie autunin, just before migrating, this bird devclops startling powers of flight, thongh I am inclined to believe it does not rely entirely on its wings in its travels to and from its winter quarters, for just abont the time of cleparture it may be found in most unlikely places; and it is just possible that when so found it may hare been traveling southwards on foot. (Nash, in MSS.)

\section{Porzana noveboracensis. Yellow Rail. Water Sparrow.}

Summer resident. Winnipeg: Summer resident; tolerably common (Hine). Fort George (Bell). Hudson's Bay (Hutchins). In a marsl near Fort Pelly I saw in few that $I$ took to be this specles; they wonld fly and drop in the sedge; did uot collect any (Macoun). At Carberry there is a small rail that is very common, but whether this or P. jamai. censis I can not be sure (Thompson).

On April 29, 1882, in the evening, while walking in the moonlight, by the slough, with W. Broclie, wo heard a peculiar "tap-tap-tap"-ing that seemed to come from something in the near sedge. When we described the sound afterwards, at the hruse, old residents said it must have been a Stake-driver.

(Since writing the abore I have become quite familiar with the Stake. lriver, or bittern, and know now that the tapping was certainly not produced by it. This peculiur sound is a charucteristic one of Manitoban marshes, and, unless it is the sound ascribed by Hutchins to the Yellow Rail, and described as resembling the striking of $\boldsymbol{n}$ flint and steel, I am at a loss to account for it.)

On Auguat 3,1883, a speeimen of a little dark rail was brought to me. I put it, aloug with two young Killdeer Plovers, into a pen, wherein was alrealy a Brahma hen with a large brood of young prairle chickens. As soon as the hell descried the strangers she male a dash and cruelly ill.treated one of the gentle killieers before I conli interfere; then she saw the rail gliding through the grass and ran towurds it with murder in her ese and fight in every fenther. Bnt the rail ran to meet her. Both flew up together-the diminutive ratl anil the vast Brahma ben. The rail rose high enungh to give the hen one peck on the bead witl bis beak, and immediately $n$ change took place. The hen straightened 
her feathers, became a "peace-at-auy-price" partisan, and never after took the slightest notice of the tiny Pozzana. It finally escaped through a hole less than an inch across. It was almost impossible to hold it in the hand, so great was its power of forcing its body through the smallest opening.

This rail I took for Porzana jamaicensis, but had delayed making a careful diagnosis to a more convenient seasol, which never came, for the bird disappeared on the first night of its captivity ; so that I do not consider the illentification at all safe. It may have been $P$. novebora. censis. One is as likely as the other, and I believe both will yet be found in the province. Certain it is that a little rail, other than the Carolina, is often flusherl in the rushes, and flies with its legs dangling; never, however, for any great distance; generally, it merely dashes out of the sedge at on place and along a few yards to drop into another. Its diminutive an aquatic habits have, in some localities, procured for it the nam of Water Sparrow.

\section{Fulica americana. American Coot.}

Common summer resident; extremely abunclunt along the line from Pembina to the Rockies; breeding (Cones). Dufferin : Arrived between April 25 and 30 (Dawson). Winnipeg: Summer resident; abundant (Hine). Oak Point: Arrived May 9 (Small). Lake Manitoba (Brewer). Portage la Prairie: Very abundant summer resident, arriving in May, departing eitrly in Octoher; tirst seen in 1884, May 6 (Nash). Carberry: Summer resident; not eommon; plain sonth of Souris River; Minnedosa, common; Portage la Pruirie, abundant in fall (Thompson). Abundant on ull pools of fresh water in the prairie region, with grebes; not common in the forest region (Maconn). Dalton: 1889, first seen, eiglit, on April 18; next seen on April 21, which was also last seen; common, but not breeding (Younans). Shell River: 1885, first seen, a pair, ou May 12; afterwards seen every day all summer; is common; it breeds here; nest found with thirteen eggs (Calcntt). Qu'Appelle; Common summer resident; breels; arrived May 6 (Guernsey).

On June 25, 1884, in a pond 10 miles west of Minnedosa, I saw four coots engaged in a curions set-to. They might have been fighting, or merely playing. They were close together, sud all were splashing the water about, flapping their wings and bobbing up and down; they facel each other, but never seemed to strike each other, so far as I could see. I huve several times seen this performance in the spring time.

The ingration of the coot is very singulur; late in the antmun 1 have seen these birds in countiess uumbers in tho marshes at tlie south end of Lake Mnnitobn; for a few inys previous to their going they keep up a ceaseless cliatter and row, nppa. rently discussing the propriefy of leaving. On my going ont some moruing after this bas gone on, not a single solitary coot is to be seen, except perhajes a wouncled ons: that call not fly ; they are unlike other birds, only migrating at uight. I have never seen a flook of them in the daytime. These marshes of Lako Manitoba appear quite

solitary afte (R. H. Hnnt Arrives ea putirely, oft iiisappeared ing season skulking an rollug have their habits hnudred tog swimming a this time the and around retire into t] at times in leave the mo

Irregula pears in : antumn vi slonghs ne and Septe

Summer to the Roc observed i mon on tl peg (Hine $15,1882($ 1880 (Mad

June 15, ropeswimm around, and

\section{A west} along the soutliwes Ottawa i Hunter). is doubtf thronglso July 25, the aikali 
never aftor oed through to hold it in tine smallest

d making a er came, for hat I do not $P$. novebora. will yet be er than the s dangling; rely dashes rop into an. ie localities,

he line from red between $t$; abundant ba (Brewer). ing in May; Oarberry: rer; Minne. (Thompson). with grebes; 9 , first seell, o last seen ; first seen, a is common ; Qu'Appelle; ej).

, I saw four fighting, or plashing the 1; they frcerl I could see. tne.

avo seen these Ianitoba ; for a nd row, appa. uing after this woundeu ous I have never a appear quite solitary after these birds are gone, although there are thousands of other birds there. (R. H. Hunter in MSS.)

Arrives early in spring, as soon as the jee goes ont, and remains until it freezes up entirely, often staying about open holes in the ice until the last drop of water has iisappeared from sight. On its first arrival in the spring and thronghont the breeding season its habits mueh resemble those of the true rails, and it is continually sknlking and hiding among the rank vegetation in which it resides; but after the yonng bave acquired strength aul confidence in themselves a change takes place in their habits. They now gather into large flocks (several times I have seen over a hunireal together) and betake themselves to the open water, where they utay be seen swimming and diving, like a lot of blue-lills or red-heads, rather than rails; at this time they will, if approacher, rise high in the air and make long flights over and arouncl the marsh they inlabit; this they will do all day long, but at dark they retire into the high rushes to roost. All the other birls of this family I have found at times in dry grassy meadows or amongst low scrub, but the coot never seems to leave the more watery parts of the marsh. (Nash in MSS.)

\section{Phalaropus lobatus. Northern Phalarope.}

Irregular migrant. Winnipeg: Transient visitor; not common; appears in spring and fall about Reaburu uarshes (Hine). Common antumn visitor to Portage la Prairie, and very abundant at the prairie slonglis ntar Winnepeg, where I saw immense flocks of them in August and September, 1886 (Nash).

\section{Phalaropus tricolor. Wilson's Plialarope.}

Summer resident; breeds throughout the country from Red River to the Rockies along the line; in suitable places common, thongh nerer observed in large numbers at any one place (Coues). Winnipeg: Common on the prairies in spring; breeding at Seaborn and Lake Winnipeg (Hine). Eighteen miles south of Brandon, a pair observed June 15, 1882 (Wooll). Breeding around ponds at Moose Mountain, July 24, 1880 (Macoun). " $P$. lobatus Ori," Severn House (Murray).

June 15, 1887, 18 miles sonth of Brandon, saw a spleulid pair of (Wilson's) Phala. rope swimming on a poul only a faw yards away; one of them kept rising and flying around, and I conld distinguish the heautiful ren aud black neck quite plainly. (Wood).

\section{Recurviroatra amerioana. American Arocet.}

A western bird, very rare in Manitoba. Winnipeg: Rare; straggler along the Red River (Hine). Have killed the bird along the Souris, southwest of Plum Oreek; in the museum of the Geological Survey at Ottawa is a specimen of the Arocet, marked from Manitoba (R. H. Hunter). (Professor Macoun tells me thut tho locality of this specimen is doubtful.-E. E. T.) Very abundant around saline pouts and lakes throngliout the Northwest; shot at the base of the Cotenu du Missouri, July 25, 1880 (Mucoun). Qu'Appello: Uccasionally here; plentiful on the alkali ponds west (Guernsey).

$$
\text { Proc. N. M. 00-32 }
$$


Very rare summ ar resident. Winnipey : rare; only two pairs killed, and under a dozer birds seen altogetber in 4 years (Hine). I saw oue specimen of the woodcock at York Factory, in the end of August last. This bird is not uncommon in Manitoba, although the fact is not ges. erally known (Bell, 1880). Oak Point: 1885, first seen May 13; rare; one was shot (Sinall). Kare summer resident; I shot ten birds in 5 years near Portage la Prairie; in 18861 found a pair breeding near Winnipeg; arrive about the end of April, depart in September (Nash).

69. Gallinago delicata. Wilson's Snipe, Common Snipe.

Abundaut summer resident of sloughs and swamps; abundant at Mouse River, on the boundary, in September (Coues). Dufferin: Arrived between April 15 and 20 (Dawson). Winnipeg: Summer resident; abundant (Hine). Red River Settlements, April 29 (Blakiston). Suipe funnu above Split Lake, and in many places along Nelson Rirer; common in Manitoba (Bell). Ossowa : Commou ; breeding; 1885, first seen, three, on May 5; n'xt seen May 8, when it became common (Wagner). Oak Point : 1885, first seen, one, on April 26; next seen, April 26; is common here (Small). Portage la Prairie : Common sum. mer resident; abuudant in spring and autumn migrations; I have, il August, frequently seen wisus containing from twenty to thirty birds; arrives in April; departs in October (Nash). Common all along the ronte of 1881 ; specimens shot at Swan Lake, Red Deer Lake, and Fort Pelly (Macoun). Carberry: Abundant; sulımer resident; breeding; Boggy Creek and various parts of the Big Plain; Rat Portage (Thompson). Two Rivers: 1885, first seen, April 6; somewhat rar:; I believe it breets here (Oriddle). Dalton: 1889, first seen, one, on April 8; next seen, on April 12, when it becane cummon; breeds here (Youmans). Shell River: 1885 , first seon, oue, on May 4 ; next sien, three, on May 8; a transient visitor, passing north; not remicining to breed (Celcutt). Qu'Appeile: Comınou summer resident; breels; arrives April 20 (Guernsey).

Snipe are now (May 5, 1882) quite numerous; they frequent the damp rather than wet places. Their principal amusement on cloudy drys seems to be dashing across the sky at height of 200 or 300 feat and uttering a loud vibratory note, which is repeated, with lessen. ing intervals, a dozen or more times; during the production of the sonnd the birl's wings seem to be rigilly set, but the tips appear to vibrate, and, at the same time, the course is obliquely downwards. As suon as the serenade is over the snipo wheels nbout, regains his eleva. tion, and repeats the performance indefinitely. Having vented the feelings which prompted these actions, he descends to a much lower level by one or two loug slanting gyrations, and then regains the earth by half slosing his wings and dropping downwards into the grass. 
The performance usually takes place in duli weather or in twilight. After it is over, I have often induced him to repeat it by marking him down and then springing him; he generally rises, uttering a sort of "screep," zigzags for a few yards, circles round tho horizon in one or two sweeping gyrations, and either pitche, dowu again to the grass or co:tiuues t.. ascend, and then repeats his song.

The next day one of the snipe's notes seems not unlike the "tow, tow, tow," of a stray turkey, but in a higher kty.

About a week after arriving in its former haunts this well-known species begius to manifest its presence by nttering the remarkable pairing serenade for which several of the scolopacine birds aro noted. When prompted to this peculiar performance the suipe-the male only, I supp:cse-rises suddenly from the bog where he has been feeling, and where his usual note is a "squeak! squeak!" and now, just after rising on his long, swift wings, this "squeak" is generally repeated a nun. ber of times. Immediately after taking wing he circles all around the marsh, then rises, silently, higher and higher, still circling, until, having reacbed an eleration of sereral hundred feet, be gathers his strength and goes whizzing across the sky, his tail spread to its utmost extent and wings vibrating with great rapidity, while a loud, sharp boom, repeatel quickly twenty or thirty times, is heard as long as this career is continued. While thus engaged the course of the bird has been straight and slightly downward, and as soon as it is ended he remounts ancl dashes across again with the same resounding accompaniment. This he will keep up for half an hour at a time. Thus having expeuded his exnberant energy, he wheels lower and drops into the slough to receive the congratulations of the ouly spectator whose atten. tion was specially courted.

This booming or whirring may be a product of the voice, or it may be caused by the wings, which appear to vibrate simultaneously with the production of the sounds, the quality of which is very nearly the same us that of the boom of the night hawk.

The favorite haunts of this bird are the open grassy slonghs or bogs which intersect the cnintrs. Here it finds in abundance the smaller insects which coustitute ite food, and here it makes its nest and rears its young. The position of the only nest of this species that I found was in a slightly-elevated tussock or sol in the middle of a wide muskeg. The nest consisted of a slight hollow, with a few straws for lining, and wus raised only about 3 inches above the water. This wus in the third week of July, and by the 27th of the month the four young ones were batched and immediately left the nest, to lead a roving life with their mother among the grassy bottoms and the muskegs, rich with an influitude of insect life. 
70. Macrorhamphus scolopaceus. Long-billeã Dowitcher, or Red-breasted Snipo.

Common, chiefly as a migrant in the western part of th : province; Mouse River, at the boundary, possibly breeling; extremely nnmerous in September (Cones). Red River Valley: Summer resident; common west of Brandon; I have shot eighty in four discharges of a gun; are never seen ill eastern Manitoba (Hunter). Winnipeg: Very rare; secured three or four near Reaburn; observed only in August and Sep. tember (Hine). Very abundant at Swan Lake House and Red Deer Lake, July aud Augnst, 1881 (Maconn).

\section{Micropalama himantopus. Stilt Sandpiper.}

One specimen procured on the plain north of Qu'Appelle September 16,1880 (Macoun). (This is just west of the province.) Have seen it in August and September on the Assiniboine, near Portage la Prairie, singly or in pairs ; rare (Nash).

72. Tringa oanutus. Knot. Robin Snipe.

Migrant. Winnipeg: Tolerably common in the migrations (Hine). I have never seon the Knot along Red River, but have seen large flocks of the species west of Brandon (R. H. Hunter).

\section{Tringa maculata. Pectorul Sandpiper.}

Migrant, chiefly in fall; common in fall migration along line at Turtle Mountain (Coues). Winnipeg: Kare; migrant (Hino). Portage la Prairie: Common in the autumn, frequenting the grassy marshes (Nash). Abundant along the route of 1881 , also on the Great Plains aud Northwest (Macoun). Moosejaw (west of Manitoba), July 7 (Miller Christy).

74. Tringa fuscicollis. White-rumped Sandpiper.

Migrant; not common. Portage la Prairie: Have occasionally taken it in antumn and more rarely in spring (Nash). Shoal Lake (south slope of Riding Monntain) and on Duck Mountain, June, 1884 (Thompson).

June 4, 1884, near Shoal Lake, saw a large flock, fifty or sixty; of White-rumped Sandpip rs as they flew along the shores of a little poud; they performed so exactly the same evolntions in closecolumn that the whole flock was entirely dark and silvery, according as they turned their backs or their breasts to me. Five specimens collected, two a ancl three ? ; all showed sexual organs enlarged ; P $^{\circ}$ very fat; all had stomachs flled with aquatic Insects; one had a ver; largo larva.

75. Tringa bairali. Baird's Sandpiper.

Fall migrant; not very common; in fall migration one of the most abuudaut saulpipers; along Monse River and westward along the line of the Rockies (Coues). Have seen it in the autumn, near Portage 
ted Snipe.

rovince ; nmerous common guu; are rare; seand Seped Deer

eptember seen it in a Prairie,

Hine). I rge flocks

at Turtle ge la Praies (Nash). ud North. (Christy).

ally taken ke (south 4 (Thomp-

sixty; of ittle pond; in that the bey turned ed, two \& at; all had rrva.

f the most along the ar Portage la Prairie (Nash). Saw a number on a salt marsh on led Deer River, Jnly 23, 1881 (Macoun). Carberry, Angust 21, 1884: Now commou about the lakes in company with the two Yellow-legs, but not in tlocks (Thompson).

76. Tringa minutilla. Least Sandpiper.

Somewhat common as a migrant; may breed. Turtle Mountain, July 30: Should not be surprised if it bred in the ricinity (Cones). Winnipeg: Tolerably conımon summer migrant (Hine). Shoal Lake, May 15, 16, 17, 1887 (Ohristy). Portage la Prairie: Very aloundant, appearing in large flocks on the sand lars in the Assiniboine River and about the prairie sloughs in August (Nash). Shot on Red Deer River, July 23, 1880 (Macoun.)

77. Tringa alpina pacifica. Red-backed Saudpiper. Blackheart.

Migrant. Winnipeg: Transient visitor; tolerably common along the river (Hine). Portage la Prairie: Tolerably common during the fall migrations (Nash). Serern House (Murray).

78. Ereunetes pusillus. Sentipalmated Sandpiper.

A migrant along Red River, Mouse River, and along the boundary at various points during August (Coues). Tolerably common along Red River in the migration, frequeuting the wet prairies near Winnipeg (Hine). Portage la Plairie: Abundant in Assiniboine in the antumn; appearing early in Angust (Niash). Shot on the led Deer River July 23, 1881 (Macoun).

79. Caldarls arenaria. Sanderling.

Migrant; numerous about Lake Winnipeg, June (Kennicott). Shot five out of a flock at Oak Lake, a prairie slough, a few miles north of Portage la Prairie, August 1, 1884 (Nash). Auundaut on the west shore of Lake Manitoba, June 12, 1881 (Macouu).

\section{Iimosa fedoa. Marbled Godwit.}

Tolerably common summer resident. Pembina, June 30, 1873, nesting (Coues). Winnipeg: Summer resident, tolerably common (Hiue). Red River Valley: Summer resident; common in Western Manitoba (Hunter). Plum Oreek: Breeding, 1852, June 20 (Wood). Plains near Loug River and South of Souris, May ; tolerably common (Thompson). Qu'Appelle: Ounmon summer reside.tt; breeds; arrives May 10 (Guernsey). Huclsın's Bay (Murray').

May 18, 1882, at Long River, north-enst slope of Turtle Mountain, U. T. shot a fine \& Marbled Godwit from the wagon; foet, black; giz. zard filled with shells and insects. They are somewhat common on 
these wide, wet plains, but all those noted have been solitary individuals. Their large size, reddish color, and long straight bills distinguish them at a great distance.

\section{Iimosa hæemastica. Hudsonian Godwit.}

Rare migrant. Winnipeg: Transient visitor; rare (Hine). Severn House (Murray).

\section{Totanus melanoleucus. Greater Yellow-legs.}

Abnndant; migrant spring, late summer, and fall; very abundant in August and September at the boundary along Mouse river (Coues). Dufferin: Arrived between April 15 and 20 (Dawson). Winnipeg: Abuudaut in summer migration (Hine). Norway House (Bell). Portage la Prairie: Abundant in spring, arriving in April, usually in pairs; about the first of August they reappear in small flocks about the rivers and open prairie sloughs, where they feed on small frogs; depart late in October; the las ${ }^{2}$ flock I saw in 1884 were flying south in a snow storm on 21st of October (Nash). Very abundant at Red Deer river and on the Assiniboine; about all ponds in the fall of 1881 (Macoun). Carberry : Abundant; migrant in spring and in late summer (Thompson). Shell River: 1885, firstseen, seven, on April 24, trausient visitor; passing north, and not remaining any time or breeding (Calcutt). Qu'Appelle: Common migrant, May 5 (Guerusey). Severn House (Murray). Very commou from the sea to Lake Winnipeg at the season (Blakiston).

August 21, 1884: Greater Yellow legs are still very common about the weedy lakes. They come down from the north about the 1st of Angust, and are to be seen usually on the points of land that run out into the ponds; as they staud motionless ou the promontories they look twice as large as they really are. They are more shy and less active than their minor brechren, for they usually stand in a dignifed way until fired at or forced to fly, seldom running in the sprightly fashion of the Lesser Yellow-leg. They differ also in their food, for I have found the larger species with numerous sinall fish in their gullets, which is unusual for a Tattler. The members of this species raise their voice in a great outcry each time a guu is fired.

\section{Totanus flavipes. Yellow-legs.}

Common migrant all over; abundant throughout the Winnepegosis region; Nelson River; chiefly notel in Assiniboine Valley about August 15; common; spring, late summer, and autumn migrant; very abundant in August and September; along the boundary at Turtle Mountain and Mouse River (Coues). Winnipeg: dbundant (Hiue). Portage la Prairie: This species arrives later than the last (Greater Yellow legs), not usually appearing before the 12th of May; they return about the first of August in flocks, and depart at the end of September, my latest record being October 1st, 1886, a single bird, near the Ked River

(Nash). lant $a b$ river : 1 ing nor pelle: $C$

Ohiefl migratic Winnip Tolerab the nest il Septe along t feathere la Prair

Septe

On Juls itarius) al the dry $b$ species.

Toler: points \& Plain, n son). east sid land oft bollow, by a $\mathrm{t}$ $2 \frac{1}{b y} 1$ dark s] approad

86.

Abur over $t$ Mouse mon (I Pruirie 10 ( $\mathrm{Nas}$ not se residen 'Turtle 
individ. distin.

Severn

andant in (Coues). innipeg: 1). Portin pairs; the rivers art late in how storm er and on an). Carhompson). $r$; passing 'Appelle : (v). Very iston). non about the 1st of at run out ories they 5 and less a dignified chtly fash. for I have lets, which their voice

nnepegosis lley about rant; very at Turtle int (Hive). st (Greater hey return September, Red River
(Nash). Carberry: Common migrant in August (Thompson); abundant about all pools in the fall, aloug the route of 1881 (Macoun). Shell river : 1885, first seen, three, on April 24 ; transient risitor, only passing north, and not remaining any time or breeding (Oalcutt). Qu'Appelle: Common migrant; May 5 (Guernsey). Severn House (Murray).

84. Totanus solitarius. Solitary Sandpiper.

Chiefly in migrations; nrobably breeding; in abundance in autumn migration, Turtle Mountain, and Monse River at the boundary (Cones). Winnipeg: Summer resident; abundant (Hine). Portage la Prairie: Tolerably common, and I think that some breed, though $I$ hare not found the nest; arrives about May 15 ; reappears about 1st.August; departs in September (Nash). Frequent throughout the Winnepegosis region along the route of 1881 ; breeding, for young were observed July 20, feathered, but with some down yet (Macoun). Carberry and Portage la Prairie; in late s:ammer migration (Thompson).

September 16, 1884, at Portage la Prairie, shot a solitary sandpiper.

On July 10, 1834, I shot a specimen of the solitary sandpiper (Rhy acophilus solitarius) at Maple Creek, 597 miles west of Winnipeg; it was doubtless broeding. In the dry bed of the creek I also caught a nestling bird, which was probubly of this epecies. (Christy.)

\section{Symphemia semipalmata. Willet.}

Tolerably common summer resident in the south and west, at various points along the line from Red River to the Rockies (Coues). Souris Plain, wear Turtle Mountain : Nesting, near Shoal Lake in June (Thomp. son). Cominon around saline ponds on the westeru plain and on the east side of Mouse Muuntain, July 29, 1880 (Macoun).

On May 23, 1883, on the Alkali Plain, north of Turtle Mountain land office, started a willet from her nest, which was placed in a slight hollow, shaded on one side by the skull of a buftalo and on the other by a tulft of grass. It contained four eggs, each of which measured 21 by $1 \frac{1}{2}$ inches, ground color, dark olive lorown, with heavy, round dark spots of brown and purple, evenly distributed, without any approach to a rind about the large end.

86. Bartramia longloauda. Bartramian Sandpiper. Pralrie Plover. Quaily.

A bundant summer resident on the dry prairies; extremely abundant over the Ked River prairies, along the boundary, Turtle Mountain, Mouse River; breeding (Coues). Winnipeg: Summer resident; com. mon (Hine). Breeding at Selkirk Settlement (D. Gunn). Portage la Prairie: Abundant summer resident from early i!" May to about August 10 (Nash). Abundant in the prairies from Grand Valley and westward ; not seen in the forest region (Macoun). Carberry : Abundant summer residen:; breeding; in all the prairie regious to Brandon, and south to Turtle Mountain, also from Oarberry northwestward to Fort Ellice 
(Thompson). Two Rivers : 1885, first seen, one, on May 3 ; next seen, several, on May 4 ; becanie common May 5 ; breeds here (Criddle). Shell River: 1885, tirst seen, two, on May 4 ; afterwards seen every day; is common all summer and breeds here (Calcutt). Wu'Appelle: Common summer resident; breeds; arrives May 12 (Guernsey).

May 6, 1882 : For some days back I have heard a loud rattling whistle th $t$ seems to come from the skies, and sometimes $I$ have seen the bird that produces it sailing at a great height. Occusionally I hare observed it sail downwarls at an angle of 45 degrees and settle on the fence or on the prairie. To-day at noon I shot one of these birds as it was perched on a fence stake. It first alighted ou the barn, where $C$. T. fired at it, but it llew off' and alighted on the fence where I wingerl it. It did not attempt to escape, but lay on its back with its legs drawn up. I found it to be the upland plover, or quaily, as the residents call it. It was a male, length $11 \frac{1}{2}$, extension $20 \frac{1}{2}$; stomach contained iuseets and two rose-pip stones.

May 11 : Single quailies very numerous now ; they seem to sail down. ward out of the very sky, uttering their nournful whistle, like " rrrrr . phee-phee-0000!" as they sail down on the prairie, where they stand for a fow seconds, like the statue of an angel, with their wings raised aloft, donbtless to show the beautifu!ly barred under side, then delib. erately folding them they nod and step forward and nod again at each step, and pick up the unfortunate early flies, and stop occasionally to reiterate the mournful whistle and thereby conjure out of the very clouds some conurade who also sweeps dowuward, whistles, alights, strikes the vainglorious attitude, then joins in the varied pursuits of love, music, and beetles.

May 4, 1883 : Quailips noted. A. S. T. May 11, quailies very numerous now.

On June 6, 1853, while crossing the prairie near the house, I flushed a Quaily from her nest almost under my feet; she fluttered a few Jards forward and then lay flat on the prairie, beating her wings on the ground and utteriug such heart-broken cries that I could not but leave her in peace. The nest contained three eggs.

June 15. I saw a curious sight on some newly broken prairie. A Quaily had sprung from her nest just under the feet of the ploughhorses ; the man had stopped them, remored the four eggs the nest contained, ploughed on, and then, after replacing the square foot of sod the bird had nested in, restored the eggs to their place and left them. Very soon the mother bird found courage to return and resume her duties, and when I saw her, she was sitting contentedly on her eggs in this tiny green patch surrounded by acres of level black earth.

Inne 4, 1884. In this day's drive saw no pairs of Quailies, but obserred seven solitary birds. During the last week of May the speeies was always seen in pairs, and it was this that led me to count. The change noted to-day is, no doubt, due to the fact that the honey-moon

is over al actually weighs b

During t Upland Pl known as $t$ from the $\mathrm{g}$ pear to tret is frequent cessive. C of tho past shot 80 ten not easily soft, mello on the op jority left prised at

This spe Prairie, ar be seen pes himself on they deser They aro August 29 Winnipeg

Winni (Hine).

\section{Oomm}

- from Pe Summer 1880).

April 22 riving o seen by along th Portage the old

Summ about $P$ Rare sp bourne May, 18 
next seen, (Criddle). seen erery u'Appelle: sey).

tling whis- e seell the ally I hare ttle on the birds as it , where $\mathrm{O}$. I wingerl egs drawn 3 residents coutained

sail down. e "rrrrrr. hey stand ogs raised hen delib. ain at each sionally to of the very ss, alights, pursuits of

ery uumer.

, I flushed fow yards gs on the but leave rairie. A be plonghthe nest re foot of and left ad resume lly ou her ack earth. ss, but ob. he species unt. The ney-moon is over and the laying season commenced. The egg of this species is actually larger than that of a prairie chicken, although the quaily weighs but 4 ounces, and the chicken nearly ten times as much.

During the summer no bird is more familiar on the Manitoban prairies than the Upland Plover or Bartrau's Sandpiper (Bartramia longicauda), comınouly there known as the "Quaily," from ite note. Surely no bird over differed more completely from the generality of its relatives than thiy! It is a Sandpiper which does not appear to frequent marshes, which breeds habitually on the dry open prarries, and which is frequently to be seen perched among the brinches of trees. Its tameness is ex. cessive. Often when driving over the prairie I bave seen It remain within 3 yards of the passing vehicle without the slightest concerı. When on the wing, it offers a shot so temptingly easy that fow can resist. Its note is a highly remurkable one, not easily forgotten when once heard. Dr. Coues well describes it as a " long-drawn, soft, mellow whistle, of a peculiarly clear, resonant quality." It breeds abundantly on the open prairie, and I bave several times canght the young in down. The majority left Manitoba towards the latter end of August, but I was several tinies surprised at hearing or sceing a belated pnir until quite late in September. (Christy.)

This species is an abundant sunmer resilent on all the dry pralries near Portage la Prairie, arriving early in May; at this time they are very tame, and nay frequently be seeu perching on the fences, and I oncesaw one make a ludicrous attempt to settle limself on the glass insulator on top of a telegraph pole. About the 1st of August they desert this prairie and hetake thenselves to the broken land in small flock. They are then very wild. By the 10th of the month they have all left; though on August 29, 1884, I saw a eingle bird flying over. Not observed in the vicinity of Winnipeg (Nash in MSS.).

\section{Tryngitea aubruficollia. Bnff-breasted Sandpiper.}

Winnipeg: Transient visitor; rare; in migration along Red River (Bine).

\section{Actitla macularfa. Spotted Saudpiper.}

Common summer resident along streams; throughout the region - from Pembina to Rockies along the boundary (Coues). Winnipeg: Summer resident; abundant; breeding (Hine). Norway House (Bell, 1880). Shoal Lake, May 15, 1887 (Christy). Oak Point : 1884, arrived April 22 (Small). Portage la Prairie : Abundant summer resilent, ar. riving soon after May 1; departs at the end of September; the last seen by me was on the 24th of that month (Nash). Common; breeding along the ronte of 1880 and 1881 ; always seen in couples (Macoun). Portage la Prairie: July 22, 1884, saw yonng Peetweets running witb the old ones along the banks of Owl Ureek (Thompson).

\section{Numeniti'? 'ngirostris. Long-billed Curlew.}

Summer resident of the wet prairies; breeds in moderate numbers about Pembina (Coues). Winnipeg: Rare; transient; visitor (Hiue). Rare spring and autumn visitor; saw five on Rat Creek, in the Westbourne marsh, October 8, 1884 (Nash). Frequent on the Souris plain, May, 1882, frequenting the wet prairie (Thompson). 
Spring migrant. Winnipeg : Fairly plentiful, frequenting fields or flying in large compaet-flocks with other waders; goes north to breel, but is back in numbers during the summer (Hine). Carberry : Spring migrant; saw flocks on the fields May 24, 188t, and on June 3, on Rapid City Trnil; south slope of Riding Mountain, saw three; also a (Yray Plover (Thompson). Dalton: 1839, first seeu, abont a hundred, on May 27 ; are common for a few days in spring (Youmans). Severn House (Murray).

\section{Charadrius dominlous. American Golden Plover.}

Common spring and fall migrant; very abuudant along the Monse River at the bounlary, in late September (Coues). Winnipeg: Abun. dant; transient; visitant; arrives about the milllle of May ; goes north to breed; comes baek in large flocks in August; affects burnt prairie and plonghed land (Hiue). Portage la Prairie: Abundant spring and autumn visitor, occurring in large flocks; they frequent the prairie slonghs, the broken land, and are particularly partial to the burnt prairie; I lave seen them in rast numbers following the fires; they will ulight on the gronnd burnt over a few hours after the fire has passed; arrive in May, reappearing in August, and departing in Oc. tober (Nash). Oue tlock seen at Fort Pelly, September 18, 1881 (Macoun). Carberry: Common spring migrint; Long River; plain sonth of the Souris; north side of Turtle Mountain (Thom pson). Shell River: 1885, fifty or more in flocks going north on May 26; transient; visitant only ; not breeding (Caleutt). Qu'A ppello: Tolerably common migrant; May 20 (Guerusoy). Tront Lake Station and Savern House (Murray).

\section{Iggalitis voolfera. Killdeer.}

Common summer resident; abundant throughout the summer in all suitable places, Pembina to the Rockies, nloug the line (Cones). Duf ferin: Arriced between 15th and 20th of April, 1874 (Dawson). Win. nipeg : Summer resillent; plentiful ; breelling (Hiue). Oak Point: 1885, first seen, one, on April 17; next seen, one, on April 18; is common, and breeds (Suail). Portage la l'ruirie: A bundaut summer resident, arriving in April, departing nt end of September (Nnsb). Abundaut every where along the route, on Western plains, and especially on Win. nepegosis, uround the salt llcks; shot at Manitobs Honse, June 16, 1881 (Macoun). Carbern: Latterly a summer resilent, breeding abont ponds, preferubly with grnvelly or sandy shores; nenr Brandon; near Long River; Silver Oreek; near Rnpid Oity (Thompson). Dulton: 1880, first seen, five, on $A$ pril 8; next seen on $\Lambda$ pril 12, when it beenme common; breeds here (Youmans). Brandon : Breeds; eggs tnken second wiek in July, 1882 (Wood). Shell IRiver: 1855, first seen, one, male, on April 6; is a common summer resilent, and breeds bero (Calentt).

Qu'App

(Guerns

July ? on the uttering eould no straight, fuwn-lik turned $\mathrm{c}$ ing, and walked been in ? but the birls, $m$

Rrre

Winuip in June quentin (Nash). with the Mauitol 25 (Wo Americ

Migr: ably coi Giunn). palmate oll the

Migr and on linge la Winnin

Resil nipeg: fearless in Smit not occ 
hg fielils or th to breel, rry : Spring 3, on Rapid also a (tray red, on May rern House

\section{the Mouse} peg : Abun. ; goes north urut prairie t spring and the prairie o the burnt flres; they the fire has orting in Oc. 31 (Macoun). south of the River : 1885, isitant only ; igrant; May urray).

immer in all ones). Duf son). Will. Point: 1885, is coininon, ter resident, Abuudant ally on Win. se, June 16, eeding about union ; near 11). Dulton: en it beenme :aken seconil 1, one, male, ro (Caleutt).

Qu'Appelle: Common summer resident; breeds; arrives April $\mathbf{1 7}$ (Guernsey).

July 7, 1882, at Silver Creek, saw a single downling Kildeer running ou the trail just before the oxen; both its parents were flying about, uttering their loud laments and trying to decoy the young one aside, but could not get it out of the wagon rut into which it had fallen; it ran on straight, trying to keep ahead of the oxen, till I caughtit. It was the most fawn-like thing I erer saw in feathers; its large lustrous eyes were turned on me with an expression of fearless inuocence that was touch. ing, and when I set the little ball of down at liberty on the prairie it walked gracefully away without betraying any consciousness of having been in the power of its worst enemy. It was apparently newly hatched, but the markings of its downy coat were similar to those of the adult birls, minus the orange.

\section{Egialitis seimipalmata. Semipalmated Plover. Ring Plover.}

Rre migrant between Huilson Bay and Lake Winnipeg (Murray). Winnipeg. Summer resilent; rare (Hine). Common at Lake Winnipeg in June (Kinnicott). Portage la Prairie: Very abundant in August, frequenting the saud-bars on the Assiniboine with the Least Sandpiper (Nush). Abundant with Kildeer, and evidently breeding, as I saw young with them at the salt springs ou Red Deer River, July 22, 1881; at Lake Mauitoba (Macoun). Brandon : One seen April 28, 1882, another May 25 (Wood). Trout Lake Station and Severn House; plentiful in Aretic America (Murray).

94. Jogialitis moloda. Piping Plover. Ring-neck.

Migrant; possibly breeds also. Winnipeg: Summer resilent; toler. ably common (Hine). Procured four specimens at Lake Winnipeg (D. Gunn). Portage la Prairio: Occurs in the enigrations with the Semipalmatell Plover (Nash). Shot migrating in company with Sanilerlings on the shores of Lake Manitoba, June 12, 1881 (Macoun).

\section{Arenaria Interpres. Turnstone.}

Migrant. Winnipeg: Rare, but occurs abont the prairie ponds here, anit on shore of Lake Winnipeg in pairs; apparently goes north to the lurge lakes to breed; returus about the milidle of August (Hine). Lake Winnipeg (Brewer), Severn Ilouse (Murray).

\section{Dendragapus oanadonaln. Spruee Partridge.}

Resilient in tlis spruce forests of the north mul east; common. Win. nipeg : Summer resident; nbundant in spruce wools, but so tame and fearless that its pursuit enn scureely be cullel sport (Hine). A specimen in Smithsonian Institution from Reil River Settlement(Blakiston). Does not occur in the immediate vicinity of Portage la Prairie or Winnipeg, 
but I have seen numbers of them brought in to the game dealers from the woods about Lake Winnipeg, where it is resident (Nash). Swampy Island : 1885, first seen, flock of ten, on Marci 9; wext seen March 11; always common and resident; very abundunt October, November, and April; breeds here (Plunkett). Very numerous in the poplar woods to the north of Fort Pelly along Red Deer River, and at the sources of the Swan River, August, 1881 (Macoun). Rat Portage: One specimen taken by me October, 1886 ; I was informed that it is not uncommon here, though much less plentiful than the Birch Partridge or Bonasa (Thompsou). Trout Lake (Murray). In great plenty near Oumberland House (Hearus, 1771).

October 16, 1886, Rat Portage: Shot a female Spruce Partridge to.

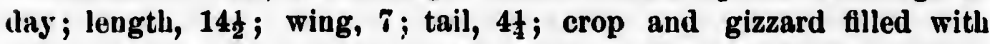
spruce leares. This is the ouly specimen seen here, but at Port Arthur, Octnber 8, I saw numbers exposed for sale in the shops; they were said to have been shot in the neighborhood.

\section{Bonasa umbellus togata. Canadian Rnfied Grouse. Birıh Partridge.}

Tolerably common in the spruce woods of the east; specimens sent to Mr. Ridgway from the "Norwest Angle" near Rat Portage hare by him been pronounced this variety; it is fairly plentiful there and known as the Birch Partridge; it is probable that all of this species found within the limits of the coniferous forest as indicated may be referred to the form of togata; therefore I assume that the following recorls belong here: "Puskee, Shoulder-knot Grouse;" this bird is an inhabitant of the southern parts of Hudson's Bay; feeds on birch buds (Hutchins, MSS. observations, Hudson Bay, 1782). Swan Lake (prob. ably) (Mncoun).

Referring to the Ruffed Grouse, the Sharptail, and the Wood or Spruce Partriclge, Hearn says: "I have seen them in great plenty near Cumberland House;" and later, in writing of the drumming of the first: "I have frequently heard them make that noise near Oumberlunil House in the mouth of May, but it was always before sunrise and a litt'e after sunset."

On Uctober 11, 1880: At Rnt Portnge some Indians oame to the door to.day with a lot of partridges to sell. These no doubt would have proved togatus, as they must have beeu taken in the neighborhord; several among them had red rufis, showing thint that variation is not confined to the sulospecies umbelloides.

At Rat Portnge, January 14, 1887, I received five partridges (var. togatus), shot in the wools just west of this point; four were inales and mensured $17 \$, 10 \frac{1}{4}, 10,18$ in length; ono doubtful was $19 \%$ iong.

Carberry specinens of umbellwa had beell referred to the form umbel. loides by Mr. Ridgway, and when he further decider my Rat Portage specimens to be togatus, there were not lacking those who ridiouler the idea of the two forms being typically represeuted within 200 miles

of each 0 the count togatus bi assigned the open .egion the

97a. E

Commo province. be of the the open :

Winnip breeding sonian In dent in $t$ if they are House, 18 1881 ; For (Macoun). south slor Mountain, mon ; per

On Apr to the slo we each s?

Bonasa

The pectin the outsid down to a : presented still rema just behin away, as in the speci various $k$ I

Second pectíuatio full of bro

April 1 male; len blunt; ped at all, as a same reme.

In the near the 
alers from

Swampy

March 11;

umber, and

$r$ woods to

sources of

o specimen

uncommon

or Bonasa

umberland

urtridge to. flled with sit Arthur, 7 were said

'artridge.

imens sent rtage hare there and his species ted may be e following bird is an birch buds Lake (prob.

10 Wood or plenty near of the first: Jumberland arise and a

to the door would have ghborhord; iation is not

idges ( 0 males ani iong. form umbel. Lat Portage to ridiculerl in 200 miles of each other; bnt a further consideration of the physical features of the country has show: the reasonableness of such occurrence, for the togatus birds were taken withiu the great coniferous forest which is its assigned locality, while the umbelloides exam ples were taken from the open aspen wools near the northeastern boundary of the dry .cgion that is inhabiter by the pale form of umbellus.

97a. Bonasa umbellus umbelloides. Partridge, or Gray Rnffed Grouse.

Common resident of the poplar woods in the west and south of the province. Specimens sent from Carberry to Mr. Ridgway prove to be of the variety umbelloides; therefore I assume that all those taken in the open and poplar woods are of this form.

Winnipeg: Permanent resident; common (Hivie). Ossowa: Resident; breeding (Wagner). Specimen from Red River Settlement in Smithsonian Institution (Blakiston). Portage la Prairie: Abundant: resideut in the woods, and frequently found in the bluftis on the prairie if they are of any extent (Nash). Heard drumming about Manitoba House, 1881 ; abundast in woods along Red Deer and Swan Rivers, 1881 ; Fort Ellice; Touchwood Hills und uorthern woods generally (Macoun). Carberry : Common, and resident in all woods; noted at south slope of Riding Mountain, Fort Ellice, west slope of Duck Mountain, und Portage la Prairie (Thompson). Qu'Appelle: Oom. mon ; permanent resideut; breeds (Guernsey).

On April 4, 1882, the snow was 3 to 4 feet deep everywhere. Went to the slough with W. Brodie. We saw several Ruffed Grouse and we each shot one.

Bonasa umbellus umbelloides, male; length $17 \frac{1}{2}$, exteusion 21 inches. The pectinations or points of its suowshoe but about half a dozen on the outside of each outer toe; the middle claw of each foot rubbed down to a mere stump, the others normal; fine, full, black ruff. The bill presented an unusual fenture, for when the mandibles were closed there still remained a wide opening right through the beak, near the tip, just behind the hook; this had the appearance of having been worn away, as no donbt it was in proceis of collecting the browse on which the species feed throughont the winter. Its crop was flled with various kinds of bnils.

Second speoimeu, female; length 16, extension 22. Snowshoes or pectinations on the feet perfect; ruff insiguifeant; bill normal; crop full of browse.

April 10, the snow still deep in tho woods, shot a Rufied Grouse, male; length 17, extension 22. Tarsi feathered to the tocs; claws luut; pectinations of toes perfect; tail nll gray without any brown at all, as also was the general plumage; ruffis very full; beak with the same remarkable mbterminal opening as that already noted on April 4.

In the spruce buah on December 5, after sundow II, as I walked near the camp, I noticed the marks in the snow where two Rnfied 
Grouse had alighted, and then withont running more than a few steps lad dived into the drift. As I came nearer the biris sprang up through the powilery snow a few feet in advance of their entering places and I secured one of them. It was of the typical umbelloides form, with gras vail and plumage; its crop was filled with catkins (hazel ?), equisetum tops, rose-hips, and various kinds of browse; probably bircli preponderated.

It seems to be the normal habit of this birl to roost in a snow drift during the coldest weather. The wonderful nou-conductivity of the snow is well known, but may be forcibly illustrated by the fact that although the thermometer registers $35^{\circ}$ below zero; the 10 inches of snow which fell before tho serere frost came, has effectually kept the wet earth in the wools from freezing, although the temperature has been at or below zero for over a week. In view of these facts it is easy to understand that the grouse in the snow drift are quite comfortable luring the coldest nights. In general the bird will be found to rnu about before burrowing into the drift; each makes its own bed, usually 10 or 20 feet from its neighbor; they usually godown a foot or so and along 2 feet; they pass the whole night in one bed if undisturbed, as the large amount of dung left behind would indicate. They do not come out at the ingress, but burst through the roof of their cot at one side; they do not usually go straight ahear and out, becnuse their breath during the whole night has been freezing into an icy wall just before their nostrils.

On December 7, in the spruce bush, shot two Ruffled Grouse this afternoou, about sniset. They "'ere rumuing abont on a snowdrift, picking the buds off the projecting twigs of a shrub that I take to bo the dwa:. birch. Oue of them was in splendici bronze plumage, $i . e$, with the ruffe ancl tail baud of a rich copper color, and the other lark marking, glossed with the same. To-day the thermometer stood at 200 below zero.

On May 24, 1883, saw a partridge on his drum.log in the eastern woods. The log looked as thongh it hul been used for severnl seasons, as it was much wom and a great quuntity of dung was lying on each side of it.

On August 21, while crossing a part of the spruce bush, I heard the warning chnckle of a partridge to her brood. I pressed quickly forwarl and distinctly saw her sitting on a stump, 30 yaris away. Fresh meat was desirable, and the young were well grown; so, hastily raising the guu, I fred, withont the slightest effect on the gray still form on the stump, but at the shot the young ones rose with a whirr and scattered? to the left. Then again I fired in haste at the form on the stump, this time with ball, and the ouly effeet wus to satisfy inyself that I hal been blazing awuy at an old knot. As I relondod I walked townrds this deceptive piece of wood, and it continued ns rigil as any other stum! until I was within 15 yards, when up it sprang and flew off in the woods in the opposite direction.to that taken by the flock. 
October 25: Birtle. During the last few days, while traveling on both banks of the Assiniboine, I have seen every shilde of brown and gray partridges together in the same regions.

November 12: Ground covered with snow ; hard frost; in sp. uce buslı with J. Dnffi on a deer hunt; saw three partrilges roostiug in an open poplar, about dusk; shot two of them. I can not understand these birds so roosting, for, in addition to the inclemency of the weather, horned owls are very numerous and very fond of partridge flesl.. It is usual for this species to roost in spruce coverts or else in a snow drift, hence it may be concluded that these two birds simply made a mistake and paid dearly for it.

On May 3, 1884, in spruce bush, I collected three male partridges; one of the gray cast of plumage, with copper ruff; one brown, ancl oue intermediate. All had their crops filled with poplar catkins.

On Thursday evening of May 29 I hearl a partridge drusaming in a low thicket by the slough. I continued to approach it by cautiously cran ling while the bird was drumming and lying still while he refrained. When at length I was within 20 feet and yet undiscorered, I esscoused myself behind a thicket and settled myself to watch. The ilrummer was standing on the log with his head and crest erect, his tail spread but the feathers on his body compressed. After looking about uncon. cernedly for a moment, he scemed to crouch a little to brace bimself; then the wings flashed with a thrump, followed by a stillness, and from the appearance of the birl one might think the pertormance enletl, but after about six seconls there is another hazy flash of the wings, accom. panied again by the thrump; in about two seconds it is repeatel, and "gain in half a second, und agnin and again, faster and fuster, until at last tio strokes run into each other and roll away like "the rumbling of distant thunder." I watched the performance a number of times. Between each " tattoo" he did not strut but remained in the same place, merely turuing his head about. Also satisfied myself that the wings beat nothing but the air. I had proviously accepted this as the correct theory, because whether it stancl on a eound or rotten $\log$, a stump or a stone, the sound is always the same, and therefore it could not drum on the percl, nor could it make the sound by benting its wings together, for when a rooster or a pigeon strikes its wings together the sound is a sharp crack, so that there is no plausible explanation other than the one abore given.

On June 19, on the west side of Duck Monntain, in a thick poplar woorls, we came on a partridge tiut erillently had a nest or a brool close at hand. She ran about our feet with her ruffe mill tail spread and her wings drooping, and whined in a manner that showed the reason of her anxiety, but we failed to tha the young or eggs.

While exploring in the Carberry spruce bush, on July 3, with my friend, Mr. Miller Ohristy, we passed a tree at whose roots wis i part. 
ridge's nest, but would not have discovered it had not the mother pursued us some 20 feet that she might begin a vigorous attack on our legs, whereupon we turned and found the nest. It was just at lhat critical moment when the young were coming out. Thuse that were hatched, some six or eight, hicl so effectnally withiu a space of 6 feet that no sign of them could be seen after the first rusb, and once hidden, they ceased their plaintive peepiug and maintained a lead silence. Meanwhile the mother was sorely distressed, running about our feet with drooping wings, whining grievously in such entire forgetfulness of herself and in such an agony of anxiety for her youug that the hardest hearted must have pitied her and have felt constrained to leave her in peace, as we did.

This nest contained one addled $e g g$ and one with a chick dead and dried in. The egg was 15 by 11 , brown, with a few dots of nmber.

Erery fieldman must l acquainted with the simulation of lameness by which mauy birds decos, or try to decoy, intruders from their nests. This is an invariable device of the partridge's, and I have no doubt that it is quite successful with the natural foes of the bird; indeel, it is often successful with man. More than once I have stood still when a clucking bird flew up, and laughed heartily to ses some tyro rushing frantically after the limping mother, shouting "Come onl she's wounded!" A dog, as I have often seen, is certain to be misled and duped, and there is little doubt that a mink, raccoon, skunk, fox, coyote or wolf would fare no butter. Imagine the effect of a birl's tactics on a prowling fox. He has scented her as she sits; he is almost upon ber; but she has been watching bim, and suddenly with a loud "whirr" (the whirr is essential, I think) she springs up and tumbles a few yards before him. The suddenness and noise with which the bird appears causes the fox to be totally carried away; he forgets all his former experiences; he never thinks of the eggs; his mind is filled with the thought of the wounded bird almost within his reach; a few more bounds and his meal will be secured. So he springs and springs, and very nearly but not quite catches her; in his excitement be is led on and away, till finally the bird flies off, leaving him a quarter of a mile or more from the nest.

If, insteat of eggs, the partridge has chicks, she does not awuit the coming of the enemy, but runs to meet and mislead him ere yet he is in the neighborhood of the brood; she then leads him far away, and retnruing githers her young together again by her voice.

When surprised sle utters a well-known danger siunal, wherenpon the young ones hide under logs and umong grass. Many persons say they will each seize a leaf in their beaks and then turn on their backs. I have never found any support for this idea, although I have often seen one of the little creatures crawl under a dead leaf.

By the end of September the young partridges ure fully grown and very fat. At this time they commonly spend the vigitt either squat.

ting un weather begin to ner as $\mathrm{tl}$

Their

but in tl

and nuts

The fl all our $\mathrm{g}$ it fairly. beat a fi hold its stealthil: discharg the shot after all

It goes quickly $t$ in a land servating wild anin daceous enemy th attitule, the situal be gained tridge an of time $\mathrm{u}$

$A$ seco animal to in motiol and the of the 0 encl I col trilge; observat it a grea nuy kind. alike. I h gray plam and black

Both eo mnjority 0 tobur 15 of these 1 
her pur.

$k$ on our

at luat

hat were of 6 feet hidden, l silence. our feet etfulness the hard. leave her

dead and nber.

lameness heir nests. no doubt deel, it is ill when a ro rushing onl she's aisled and kunk, fox, of a bird's its; he is I suddenly he springs and noise ried away; 'the eggs; nost within ced. So he hes her; in es off, leav.

; await the re yet he is - away, and

whereupon persons say in on their ough I have af.

grown and ither squat. ting under the evergreens or roosting in the trees; but when the weather gets cold and the snow lies deep, and soft in the woods, they begin to sleep in the drifts, going down nearly a foot in the same manl. ner as that described under the Prairie Chicken.

Their food at this time is chiefly browse, birch.catkins, and rose-hips, but in the summer and fall they live largely on insects, leares, berries, and nuts. In September I shot some with their crops full of acorns.

The flesh of the partridge is ranked by many as the most delicate of all our game, while the birl affords the best of sport to those who buut it fairly. But it is hard to understand the feeling of those who will beat a fine partridge bnsh with a cur that is trained to tree the bird and hold its attention by barking, while his comrade, guided by the uproar stealthily approaches within a few feet and after a long and deadly aim discharges half a pint of buckshot into the hapless bird, which, betweeu the shot and the cur, is so mangled before the musketeer secures it that after all he gets but little more than ho deserves.

It goes without saying thit an object in motion catches the eye more quickly than one at rest, ancl it is evident also that so small an object in a landscape as a rabbit or partrilge will almost certainly escape observation if it be completely at rest. This fact is so rell known to most wild animals, especially those that are continually harassell by the pre. daceous kinds, that the moment they perceire the approach of an enemy they become motionless as statnes, and, no matter what their attitude, move neither eye nor limb till they have thoroughly taken in the situation and satisfled themselves that there is nothing furtlier to be gained by concealment. This habit I have often noticed in the par. tridge and have observel it maintain its fixity for a remarkable length of time under very trying circumstances.

A second purpose served ly motionlessness is that of enabling the animal to observe accurately the motions of its enemy. An observer in motion can not accurately gange the slight morements of another, and the only resource is to pause often so that the relative movements of the object wateherl may be ganged against t'le background. This end I conceive is exactly met by the nodding head of the walking partridge; its body continues in steady progression, but its eje or base of observation is for a moment in each step at a standstill, thereby giving it a great advantage.

Ou the 14th October, 1884, whilat Prairio Chicken shooting, we found and shot a large full plunaged male partridge ou the open prairie, at lenst a mile from cover of any kind. This species exbibits great variation in plumage, hardly any two belug aliko. I have fonnd the extreme phases as follows : Rufous plumage with black ruffs; gray plumage with black ruff $r$; both above colorations of plumage with copper ruff's atsel black tail bars.

Both colorations of plumase, with copper ruffs and copper tail bars; the great mnjority of birds, howovor, aro intermediato between theso phases. Between Octobur 15 and December 9, 1886, nenr Winnipeg, I took one hundred and eighteon of these birds, amonget them thirty-one adults in full plumage. The following Proc. N. M. $90-33$ 
nemoraudum, made at the time, shows the relative proportions of the abovementioned phases :

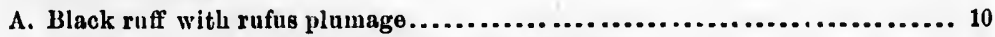

13. Copper ruff, rufus plumage, with copper tail band...................... 2

C. Black ruff with gray plumage....................................... 8

D. Dark intermediate ruff, gray plumage............................ 1

Intermediates :

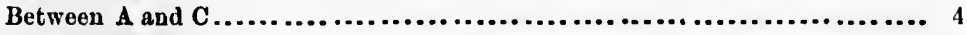

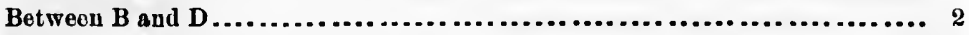

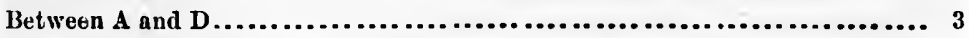

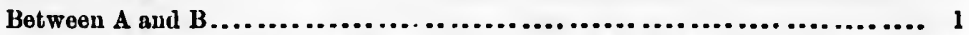

The remainder of those taken exhibit every possible variation between these forms. (Nash, in MSS.)

98. Lagopus lagopus. Willow Ptarmigan, or White Patridge.

Abundant winter visitant to the wooded regious of the Northeast. iVinnipeg: Winter visitor; rare; abundant at upper end of Lake Win. niipeg (Hine). Swamp Island : 1885, first seen, a flock of about twenty on February 16; next seen on February 21 ; is commou in severe wisters ouly; is usually rare; does not breed here; 1886, first seen, about ten, on January 12; the bulk arrived March 8; last seen, March 21; was abundant this Jear (Plunkett). Northern part of Red River Valley: Transient visitor in winter and very rarely (Bunter). Near Lake Winnipeg, at Fort Cumberland aud to the easiward, they are commou every winter (Brewer). Very seldom to be seen south or west of Lake Winnipeg, but is found in all the country north and east of that lake luring the winter season (D. Gunn). Portage la Prairie, 1884: Saw three brought from Lake Winnepegosis lasi winter (1883); it is said to be a regular winter visitant to Lake Manitoba, generally in January and February (Nash). In the year 1819 its earliest ap. pearance at Cumberland House: was in the second week of Norember (Richardson). Common every winter near Fort Cumberland (Blakiston). Norway Rüuse (Bell),

These birds are very numerous at the uortheru settlements, likewise on the eastern coasts of the bay. I have known upwards of ten thousand eaught with, nets at Severn from the month of November till the ond of April. (Hutchlns MSS., Observatious on Hudson Bay, 1782.)

\section{Tympanuohus amerioanus. Prairio Hen, or Plnnated Grouse.}

Abundant resident in the cultivated sections. In 1872 Dr. Ooues wrote: "I have no reason to believe that it occurs at all in north western Minuesota or northern Dakota. * I lave met witl no indication of its oecurrence north of the United States boundary." In 1882, when first I visited Manitoba, tha species was nearly unknown in the comntry, the only known specimens having been taken near Wirmipeg in 1881. In 1883, Mr. Hine informs me, it began to be common at Pembina. In $168+$ it was not ouly common at Wiunipeg, but had also 
he above10 2 8 1 4 2 3 $\ldots \ldots 1$ ween these ge. Sortheast. Lake Win. ut twenty in severe first seen, en, March Red River er). Near 1 , they are th or west nd east of la Prairie, iter (1883); generally barliest apNovember nd (Blakis-

in the eastern with nets at tchins MSS.,

rouse.

Dr. Ooues orth western ith no indi. ? In 1882, nown in the r Wirulpeg common at out had also

male its appearance at Portage la Prairie, on the Assiuiboine, where, according to Mr. Nash, it is now (1890):

liesident; increasing in number every year. 'The first $I$ heard of was killed in the fall of 1882, about 8 miles north of Portage la Prairie. In $1883 \mathrm{I}$ hearl of them in one or two places. In $188 \mathrm{i}$. killed several and hearl of them from most of $\mathrm{my}$ friends who shoot. Those I saw were all young birds except one. This was in full plumage. In April, 1885, I put np several singie birls on a piece of breaking, and afterwards heard in various directions their peculiar booning. Since that they have become tolerably conimou.

Red River Valley, 1885: It is now a permanent resident here, but only during the past few years; thoy are gradually working their way north from Minnesota, and have appenred at Westbourne (Hunter). Carberry: In December, 1886, I found it had made an appearance there, having been observed; also at Melbourne; in 1890, Mr. Hine writes ne that it was now an abundant summer resilent (Thompson).

On December 1, 1886, was shown a Prairie Hen (Tympanuchus amerip(mus) shot near by, and was told that young Ed. Thompson shot another here last fall. Previously the bird was nnknown in the neighborhood. December 20, at Melbourne, 7 miles east of Carberry, saw two Prairie Hens. The species is evidently working towards the north and west, no doubt following the plow.

The first information I recejved of the appearance of the Pinnatel Grouse in this province was trom a farmer, living about 8 miles not.. of this town (Portage la l'rairie), who had shot one in the fall of 188.2. I dill not see the bird, but from the description he gave me of it I conld not mistake it. I inmediately made inquiries among the hunters of this locality, but no one else had seen it. In the fall of $1883 \mathrm{I}$ again heard of the bird in one or two places, bnt saw none myself. In the fall of 1 $\$ 34$ it became plentiful, comparatively speaking, in this neighborbood, and to the eistwarl, that is to say between here and Winnipeg, I had the good fortune to secure two specimens in rather a lucky fashion. I was out with a friend chicken-shooting, October 6, 1884, at Burnside, a settlement 10 miles west of this town, when we saw a large flock of grouse alight in a stubble field near us. When wo reached the field three birds got up, of which I killed two with the first barrel, and the other with the second barrol. Of the two first killed, one was a Pinnated Gronse, the other a Sharptailed Grouse; the one killed with the second barrel was a Pinnated Grouse. I got no others, bnt hearl of then froin nearly all of my acquaintauces who hnnt. Strange to say, all that were obtained, except one, appear to have been young birds, and this oue was in full plumage, having on each side of the neck the long pointed feathers peculiar to the upecies. So far as I can learn with any degree of certainty, these lirds are uot jet (Mareh, 1885) found nunch west of the place where I killed mine, nor farther uorth than 10 or 12 miles from Portage la Prairie. They are evidently working in here from Minuesota and Dakota, and are following the grain. Up to this time the Sharp-tailed Grouse lins been very abundant, but, as might bo expected, it is getting scareer in the vicinity of tho towns. So far, both birds here associate together when they pack and find food in tho stnbbles. (Nash, in Professor Cook's report on milgration, 1885).

In 1886, near Wiunipeg, I found then abundant, about one-third of the Prairio Gronse seen being of this species. They do not visit the deep wools as do the Sharptailed Grouse, but in the winter frequent the wiliow shrub for shelter. Nor do they so often alight on trees as the other speoios. The serrationsenttached to their toes are mureh smaller than those of either the Ruffed or Sharp-tailed Gronse, which may perbaps be the reasun. 
When feeding on the stublbles both species of Prairie Gironso associate together itt the packs, but separato when the Sharp-tails go into tho woods. (Nash, in MSS).

100. Pediocætes phasianellus. Northern Sharp.tail Grouse.

Resident in the Northtast. jome of these birds were shot near Dogshead Lake, Winnipeg; thence I have found them eastward, as far as Long Lake and Pie River, on Lake Superior (Bell, 1380). Mr. Ridgway informs me that the Smithsonian Institution has a specimen of true phasianellus from Lake Winnipeg; at Rat Portage also I saw several specimens shot in the vicinit: (Thoonpson). Tront Lake Station (Murray). In great plenty near Dumberland House (Hearne, 1771).

I bave seen them in great plent,y near Cnmberland House * * " frequently perch on the tops of the highest poplars, out of moderate guushot, and will not suffer a near approach. Theg sometimes, when disturbed in this situation, dive into tho snow; but the sportsman is equally balked in his expentations, as they force their way 80 fast under it as to raise for flight many yards distant from the place they entered, and very frequently in a different direction to that from which the sportsman expectg. This I assert irom my ow experience when a.t Cnniberland House. (Hearne.)

Aukuskou, Pheasant grous * * * These birds keep in pairs or an all flocks and frequent the Juniper plains all the year. The buds of these trees are their prin. cipai food in rinter, as their berrios are in summer. 'They generally inhabit abont the same spot, unless disturbed; t heir flights are short. They frequently walk on the ground, and when raised will fly on the top of an adjacent treo. In June they make a nest ou the ground $x$ ith grass and line it with their own fenthers. They lay from four to seven whits eggs, with colored spots, and bring forth their young about the middle of June. (Hutchins MSS., Observations on Hudson Bay, 1782.)

Kat Portage, October 11, 1886. Some ildians came to tho door to-day with Prairie Chickens to 3ell. So fur as I could judge these did not differ from specimens seen st Port Arthur, and were probably referable to the typical form. (E. E. T.)

100a. Pedlocretes phasianellus campestris. Prairie Chiekcn.

Abundant and resident throughout the South and West (the Carberry form is, according to Mr. Ridgway, nearer to campestris than to phasianellus); abundant resident; abounds from Pembina to the Rockies, along the line (Uoues). Winnipeg: Stiukiug River and Long Lake; summer resident; abundant (Hine). Red River Settlement (B.akiston). Several times observed from the traius between Winnipeg and Rat Portage (Thompson). Ussowo : Resident; breeding (Wagner). Portage la Prairie: Abundant; resident (Nash). Very abundant on the prairies from Livingstone south ward in 1881, but not noted at all in the Wiunepegosis region (Macoun). Carberry : Abundant; resident; partly migratory, as it lives on the prairies in summer an $l$ in the woods in winter; noted at Sewell, Chater, Brandon, north slop, 9 of Turtle Mount. ain as far af Pelicn Lake, throughout the country from Oarberry to Fort Ellice, and northwards in prairie localities to Cote's Reserve (Thompsot). Qu'Appelle : Uonimon; Jermanent resident ; breeds (Gnerusey).

A pril 18, 1882. Saw a flock of about thirty Prairie Chickens. Shot

olle and

Length

perfect.

highest

of deatl

which it

sound 0

April

to be re

April

of the sl

April

me a $\mathbf{P r}$

12. $\mathbf{M y}$

there mo and add

No. 1.

chrome.y

but abou

No. 2.

tinations

May 8

May 9.

two male

saud.flow

the air.sa

tinations ouly.

May 1 whatere

ilay $1:$ luct was about th

May 1.

(female) rose-hips patens).

May 1

Prairio ( catkins a olive in

Sept. west of $t$ and the

In Ma I have s 
ogether itx n MSS).

ar Dogss tar as Ir. Ridg. n of true in several ion (Mur).

frequently rill not suf, dive into they force a place they the spurtsand House.

on all flocks o their prinabit abont tly walk on Juno they 3. They lay oung about 2.)

with Prairie neus seen at

sen.

t (the Car. ris than to ina to the and Long Settlement Winnipeg (Wagner). dant on the at all in the ent ; partly oods in win. irtle MountOarborry to o's Reserve int ; breeds

kens, Shot one and identified it as the Pedioccetes phasianellus. It was a femalc. Length 17, extension $2 \tilde{s}_{2}$ inches. The pectinations on the toes very in:perfect. Some of its comrades flew off and perched on tops of the highest trees. While the one I had shot was struggling in the agonies of death, its tail was rapidly vibrated, so that the hard stiff feathers of which it is composed prociuced a loud rustling noise, somewhat like the sound of a newspaper shaken violently.

April 19. Large numbers of Prairie Chickens about. They are said to be returning from the woods.

April 21. Numbers of Prairie Ohickens about. One was on the roof of the shanty making a curions crowing noise.

April 29. Went to spruce brush with A. S.T. On the road he showed me a Prairie Chicken. I dropped it at 40 yards with a half charge of Ne. 12. My brother remarked that they were never alone at this season; there must be another near by ; and presently I saw its head in the grass and added it to our bag. Both were males.

No. 1. Length 18 , extension 26 inches; bare skin over the eye, bright chrome-Jellow; air sacs purplish; all pectinations gone from the toes but about 6 points ; claws very blunt.

No. 2. Length 18, extension 27 inches; exactly as above, but pectinations of the toes complete yet and claws quite sharp.

May 8. Prairie Chickens abundant now on the prairies.

May 9. Three Prairie Chickens lorought to me to-day by the boys; two males ; one female; crops of all were filled with willow catkins, sand-flowers (Anemone patens), and rose-hips. The female was without the air-sacs on the neck or the yellow over the eje. One had no pectinations on the toes, the other two had the imperfect remains of them only.

May 10. Prairie Chicken (male) shot to.day shows no pectinations whatever on the toes.

May 12. Brandon. C. T. shot a Prairie Chicken (female). In the ovaluct was an egg nearly ready to be dropped; it was of a rery pale blue; about the color of a blue.bird egg.

May 15. Camp 30 miles south of Souris. Shot a Prairie Chicken; (female); toes quite clear of pectinations; gizzard and crop filled with rose-hips and the fleshy flower receptacles of the sand-flower (Anemone patens).

May 16. Canı 10 miles east of land office, Turtle Mountain. Shot a Prairie Chickeo (female) ; no pectinations on toes ; crop full of willow catkins and gand-flowers; one egg ready to be laid; it is pale bluish olive in color.

Sept. 23. Prairie Chickens were numerous to.day in a little grove just west of the house. Sprecimens shot showed the feathering of the legs and the pectinations of the toes in full derelopment.

In Manitoba this birl is always spoken of ws the Prairie Chicken. I liave severai times heard this name objected to by Eastern naturalists 
as being preoccupied by the Tympanuchus americanus, but I would sub. mit that the latter is always known as the Prairie Hen; * and though but a fue distinction it is a distinction, and it is better that it should remain, rather than attempt the alteration of nomenclature that has become as much a part of the lauguage as the conjugation of the verb "to be."

This eminently prairie bird in the summer time usually retires to the woods and sand hills on the approach of winter; but in the spring, before the snow is gone, they again perform a partial migration and scatter over the prairies, where aloue they ure to be found during the summer. They are very shy at all times, but during the winter the comparatively heedless individuals have been so thoroughly weeded out by their numerous enemies that it requires no slight amount of stalking to get within rauge of a flock in the spriugtime.

The advent of the grouse on the still suow-covered plains might prove premature, but that they find a good friend in the wild prairie rose (Rosa blanda). It is abundant everywhere, and the ruddy hips, unlike most fruits, do not fall when ripe, but continue to hang on the stiff stems until they are dislodged by the coming of the next season's crop. On the Big Plain stones of any kind are unknown, and in uearly all parts of Ḿanitoba gravel is unattainable during the winter; so that the "chickel: "and other birds that require these aids to digestion would be at a loss were it not that the friendly rose also supplies this need ; for the hips, besides being sweet and nutritious, contain a number of small, angular, hard seeds, which answer perfectly the purpose of the gravel. To illustrate the importance of this slurub, in this regard, I append a table of observations on the crops and gizzards contents of grouse killed luring the various mouths as indicated:

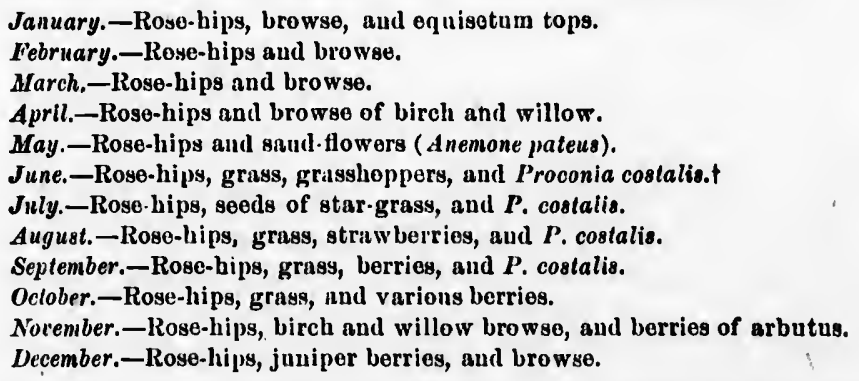

This is, of course, a mere list of staples, as in reality nothing of the nature of grain, fruit, leaves, or insects cnmes amiss to this nearly om. nivorous birc, but it illustrates the importance of the rose-hips, which

\footnotetext{
- Unfortuuately, this is an error. One rarely hears the namo Prairie Hen applied to the Tympanuchus in the prairie States, whore its almost universal name is Prairio Chicken, often shortened to simply Chicken.-R. R.

tAs this insect is found all sumwer, it may prove not coslalis, but a nondescript.
}

are alws ripe. I of gizza one der the serv being $\mathrm{s}$ possibly thinning After weather: of from what is It presel life. At tudes, w wings ne sacs and shortest sound is of bubb] with its noise, an of itself

As 800 erowing, faster an about, th a brief $s$ afterward are again

The WL. to sugges cise. $\mathrm{Th}$ and as if aud the dulged is ally at it question nies. $\mathrm{T}$ brief set drummin small bir

The w Europea pect the hill thoy 
ild sub. though ; should hat has he verb

atires to spring, ion and ring the nter the eded out stalking

s might d prairie dy hips, g on the seasoli's in vearly ; so that digestion plies this n a num. purpose n this reards con-

$$
\text { : }
$$

rbutus.

ing of the cearly om. ips, which

Hen applied ne is Prairio indescript. are always attainable, as they grow everywhere and do not fall when ripe. In the course of my experience I have examined some hundreds of gizzards of the Prairie Chicken, and do not recollect ever finding one devoid of the stony seeds of the wild rose. It is probable that the service is mutual, for these seeds secure a better clistribution after being swallowed by the grouse; and as they were passed out with possibly increased vitality they may germinate more readily for the thinning their outer coat would receive during the grinding operation.

After the disappearance of the snow and the coming of warmer weather, the chickens meet every morning at gray dawn in companies of from six to twenty on some selected hillock or knoll and inclulge in what is called "the dance." This performauce I bave often watched. It presents the most amusing spectacle $I$ have yet witnessed in birl life. At first, the birds may be seen standing about in ordinary attitudes, when suddenly one of them lowers its head, spreads out its wings nearly horizontally and its tail perpendicularly, distends its air sacs and erects its feathers, then rushes across the "floor," taking the shortest of steps, but stamping its feet so hard and rapilly that the sound is like that of a kettle drum ; at the same time it utters a sort of bubbling crow, which seems to come from the air sacs, beats the air with its wings, and vibrates its tail so that it produces a low, rustling noise, and thus contrives at once to make as extraordinary a spectacle of itself and as much noise as possible.

As soon as one commences all join in, rattling, stamping, drumming, crowing, and dancing together furiously ; louder and louder the noise, faster and faster the dance becomes, nntil at last, as they madly whirl about, the birds are leaping over each other in their excitement. After a brief spell the energy of the daucers begins to abate, and shortly afterwards they cease and stand or move about very quietly, until they are again started by one of their number "leading off."

The whole performance reminds one so strongly of a Cree dance as to suggest the possibility of its being the prototype of the Indian exereise. The space occupied by the daucers is from 50 to 100 feet across, and as it is returnec. to year after year, the grass is usually worn off and the ground trampled down hard and smooth. The dancing is inlulged in at any time of the morning or evening in May, but it is usu. ally at its height before sunrise. Its erotic character can hardly be questioned, but I ctin not fix its place or value in the nuptial ceremo. nies. The fact that $I$ have several times uoticed the birds join for a brief set-to in the late fall merely emphasizes its parallelisin to the lrumming and strutting of the partridge, as well as the singing of small birds.

The whole affuir bears a close resemblance to the maneuvering of the Euronean Rnfif, and from this and other reasons I am inclined to sus. pect the Sharptail of polygamy. When the bircls are disturbed on the hill thoy immediately take wing and scatter, uttering, as they rise, 
their ordinary alarm note, a peculiar vibratory "cack, cack, cack." This is nearly always uttered simnltaneously with the beating of the wings, and so rarely, except uncer these circumstances, that at first I supposed it was cansed by the wings aloue, but since have heard the sound both when the birls were sailing and when they were on the gronnd, besides seeing them fly off' silently. They have also a call-a soft, clear whistle of three slurred notes, E A J-and a sort of grun.t of alarm, which is joined in by the pack as they fly off. Their mode of flight is to flap and sail by turus evers 40 or 50 yards, and so rapicl and strong are they on the wing that $I$ have seen a chicken save itself by its swiftness from the first swoop of a Peregrine Falcon, while au. other was seen to escape by flight from a Suowy Owl.

The nest of this species is placed in the long, rauk grass under some tuft that will aid in its concealment, and is usually not far from a tract of brush land or other cover. It is little more than a slight hollow in the ground, arched over by the grass. The eggs, usually fourteen, but sometimes fifteeu or sixteen in number, are no larger than those of the common pigeon, and are actually smaller than those of the Uplancl Plover, a bird which is only one-eighth of the chicken's weight. Im. mediately before expulsion they are of a lelicate bluish green; on being laicl they show a purplish grape-like bloom; after a few days expos. ure they become of a decp chocolate brown, with a fow dark spots. After a fortnight ha iranspired they are usually of a dirty whito; this change is partly due to bleaching and partly to the scratching they receive from the mother's bill and feet.

A partial history of the young in a wild state is briefly as follows: At the age of 6 weeks they are fully feathered and at 2 months fully grown, although still under guidance of the mother at this time. There is nsually not more than six or seven young ones left out of the original average brool of fifteen, which statement shows the number of chicks which finl a prey to their natural enemies, waile many seto of eggs also are ilestroyed by the fires which aununlly devastate the pruiries. As the fall advances they gather more and more into flocks uncl become regular visitors to the stubble fields, and, in consequence, regular articles of diet with the farmers until ilse first fill of suow buries their fo: aging gromuds and livives thom en masso to the wiods.

During the summer the habits of the chickens are eminently torres. trial; they live, feed, and sleep almost exclusively on the ground; but the first suow makes it radical eliange. They now net more like a propcrly alapiced perching bircl, for they spend a large part of their time in the highest trees, flying from one to another and perching, brows. ing, or walking ubout mong the branches with perfect ease, and ovi. deutly at this time preferring un urborenl to n cerrestrial life. When thus aloft they are not at all possessed of that feeling of security which makes tho similarly situated IRuffed Gronse so easy a prey to the pot. lunter. On the contrary, their perfect grasp of the situation usually 
." This o wings, st $\mathrm{I}$ silp. eard the e on the a call-i grunt of mode of so rapid ave itself while au.

der some m a tract hollow in rteen, but ose of the o Upland ght. Im. ; on being ys expos. ark spots. hite; this hing they

ly as fol2 months this time. out of the ( number many sets instate the into flocks isequence, II of sllow lse wiods. tly terresouiul; but ke a prop.their time gg, brows. e, and ovi. fe. When rity which to the pot. ou usually renders thom shy and induces them to fly long ere yet the sportsman has come near enough to be dangerous.

Like most of the members of its family, the Prairie Chicken spends the winter nights in the suow, which is always soft and penetrable in the woods, although out on the plains it is beaten by the wind into drifts of ice-like hariness. As the evening closes in the birds fly down from the trees and either dive headlong into a drif $\mathrm{c}$ or ru nabout a little and select a place before going uncler. The bed is generally about 6 inches from the surface and a foot long from the entrance. Each iudi. iilual prepares his own place, so that a flock of a dozen chickens may be scittered over a space of $\mathbf{5 0}$ yards square. By the morning each bird's breath has formed a solid wall of ice in front of it, so that it in. variably goes out at one side. The great disadvantage of the snow bed is, that when there the birds are more likely to become the prey of foxes and other predaceous animals, whose sagacious nostrils betray the very spots beneath which the uususpecting bird is soundly slumbering. I am inclived to think this is the only chance a fox has of securing one of the old birds, so wary are they at all other times.

As the winter wawes it is not nncommon for a snowstorm to be ac. companied by sleet. The storm at once drives tho chickens iuto the drifts and afterwards levels the holes they formed in entering. The freezing of the sleet then forms a crust which resists all attempts at es. cape on the part of the birds, many of which, accorling to the account of lunters, are starved and thus perish miserably. I met with a single instauce of this myself.

Before the winter is over, many of the birls, by continuously pulling off fruzen browse, hare so worn their bills thit when closed there is a large opening right through immediately behind the hook.* Early in A pril the fow that bave survived the rigors and perils of their wiuter life spreal over the prairie ouce more uul soou scatter to enter ou their duties of reproduction.

The growtli and shedding of the pectinations on the toes I have re. corded at lengtli, und not having henrd of any use for them, conceived the idea which I have alrealy published (1883), that they are intended to act as suowshoes, aud the fact that they grow in the fall and con. tinno in perfection all winter, only clropping off after the snow is gone, instifies this conclusion. The same remark upplles to the similar ap). penchiges of the Ruffed Grouse. The tail seems to present a curious specializat: on, most marked in the outer fenthers; its chief function in jife appears to be making n noise. The centrul pair of soft, long, silent fi.:thers stand out like monuments of what the tril useel to he in the paimy clays of the specles, when not mere hublub in the maliling crowi on the nolsy dunce-hill, but dainty decorntion wis the charu by whioh chiefly tho pediocretes wooed ind wou his mate.

\footnotetext{
"The same remark applies to tho partridge.
} 
101. Ectopiates migratorius. Wild Pigeon.

Tolerably common summer resident of wooled regions; countless flocks in Rel River Valley late May and early June, 1873; breeding; a few seen in Turtle Mountain (Coues). Dufferin : Arrived May, 7, 1874 (Dawson). Winnipeg: Summer resilent; tolerably common (Hiue). Ossowo: Rare : breeding; 18\$5, first seen, two, on April 18; next seen, April 10; seldom seen here (IVaguer). Oak Point: 188t, arrived June 20 (Small). Portage la Prairio: Common summer. resident; arriving abont the first week in May, leparting at the end of September; on May 21 fresh eggs were found (Nash). Sarden Island, Lake of the Woods; Penuawa River; Fort Garry, 1858, pigeon uets were in use near Fort Garry ; Portage la Prairie, 1858, June 17, pigeons were flying in vast numbers over the Assiniboine; Souris River, near Spencer Kuob, 27 Juue, 1858, vast uumbers of pigeons were flying in a nortlıwesterly. direction (Hine). Found a few breeding on Waterhen River in 1881; about a dozen nests; in early fall saw great numbers in the Swan River region (Macoun). Carberry: Tolerably commen spring migrant; prob. ably breeding; south slope of Ridling Mountain (Thompson). Two Rivers: 1885, on May 14, saw several; they did not alight (Criddle). Shell River: 1885, first seen, five, on June 15; odd pair's breed here (Caleutt). Qu'Appelle: Occasional; May 10 (Guernsey).

On May 17, 1884, saw flocks of wild pigeons flying westward, and on July 22, Portage la Prairie, saw u number in the woods along the river. A pparently they breed in this region, and if so, no doubt as isolated pairs, for I am not aware of the existence of any extensire rookeries in the provinee.

Pigeons of a small size, not larger than a tlirush, are, in some summers, found as far north as Churchill River. The bill is of n tlesh color, legs red, and the greatest part of the plamnge of a light lilne or bluish. In the interior parts of the country they fly in large flocks and perch on the poplar trees in such numbers that I have seen twelve of them killed nt owe sluot. They ususlly feed on poplar burls and are gool enting, though seldom fat. They build their uests in trees, the same as the Wood Pigcous do; never lay but two oggs, and are very scarce near the seacoast in all the nortliern parts of Hudson's Bıy. (Henrno.)

Merue rouck plgeons. The first species I shall take notlce of is one I recoivel at Severn, in the yenr 1771, and, lunving sent it home presorved to Mr. Iennant, he informed me it was the migratorin species. They are very numefous inlasd nud visit our settlement to tho southwnrd in snmmor. They aro plenty nbout Mooso Fort and inluud, where they breod, choosing nu nrboreous sltuatlon. The gentlemen number then amongst the unny dellencies Hulson's Bny ntlords our tablas. 'T is a hardy biril, continulng with them till December. In sumuser their fool is berries, and when thene nre coveref with anow they ent the junlper buds. They lny two eggs nud nre gregrions. - " About twenty-six yenrs ngo these pigeons ingrigted up as lifgla us York Fort, but contiuned only two days, (Hutchius MSS.; Observations on Hudyou's Bay, 17*2.)

A few hories of Indinus thut frequent the low llonded tractsat the sonth end of Lake Winuipeg subsist principally on the pigeons during n perial of the summer when the sturgeon thohlug is unproductlve and the Zezania aquatica has not yet ripened, but firther nort! ardson, 1827

Garden Is] migratoria) deuse masse

In a whes several pige frame. One under the ne fence or bus succeeded in dead trees used as deco

On Water was under a from the gro egrgs were cl as sho sat.

In the latt the Upper A the berries o tound thom

1 think, to 1 rencmber which were the tnil was statement is

'They bree slielled and

They do a in small onk

On the 27 having its $\mathrm{c}$ Early in

Rare su common \& l'ortage ls ing in sm two eggs me near Turtle M mer resid

Toleral seen in tl or two ol 1859 , the while th 
further north these birds are too fow in number to furvish a material of diet. (Richardson, 1827.)

Garden Island, Lake of the Woods. Large flock of Passenger Pigeous (Columba migratoria) flew backwards and forwards over the island, occasionally alighting in deuse masses in the small groves. (Hind, August 24, 1857.)

In a wheat field opposite St. James Church ( 2 miles west of Fort Garry) were several pigeon traps, constructed of nets 20 feet long by 15 broad, stretehed upon a frame. One side was propped up by a pole 8 feet long, so that when the birds passed under the net, to pick up the grain strewed beneath, a man or a boy, concealed by a fence or bush, withirew the prop by means of a string attached to it, and sometimes succeeded in entrapping a score or more of pigeons at one fall. Near the net some lead trees are placed for the pigeons to perch on, and sometimes stuffed birds are used as decoys to attract passing tlocks. (Hind, 1858.)

On Wuterhen River, June 23, 1881, I found a few wild pigeons breeding. There was nuder a score of nests and they were vuriously placed, some of them but 10 feet from the grounci and not in large trees. Thoy were such flimsy structures that the eggrs were clearly seen through the interstices from below, and ono old bird was shot as sho sut.

Iu the lattor part of August and the early part of Septenuber I saw great flocks on the Upper Assinilolne, and on Swan River nbove Livingston. They wore feeding on the berries of Cornus stolonifera. In all my travels in tho northwest $I$ have uever since found thom breerling. (Prof. John Macoun in MSS.)

1 think, too, we have fur less birds than formerly, especinlly wild fowls and pigeons. 1 remember when I used to seo tlocks of pigeous following the course of the Red River which were so large that the front of each flock was ont of sight in the north whilst the tail was ont of sight in the sonth, but they nover come now. (Donald Murruy's statement in 1887 to Miller Christy, referring to the enrly days of tho colony.)

They breed early, as I shot a temiale ou Mas 31, 1884, containing an egg properly shelled aul just reacly for extrusion.

They do not in this locality bnild in colonies, but piace their nests singly, usually in small oaks, the unales at the time the fomales are incubating keeping in small flocks.

On the 27th of June, 1885, I sliot fourteen of these birds, all males, ench one of then luving its crop cramined full of green caterpillars, mostly of one species of geometra. Early in July the yuung appear with the old ones of both soxee. (Nash, fu MSS.)

\section{Zenaldura macroura. Mourniug Dove.}

Rare summer resilent of the southern part of the first prairie steppe; common at Pembina in June (Cones). Winnipeg: Rather rare (Hine). Portage la Prairie: Tolernbly common summer resident nenr here, breeding in small will plum trees; arrives in May; nest found containing two eggs, on which birl was sitting June 7, 1885; not observed by me near Winuiper (Nush). Never seen at Curberry; once noted at Turtle Mountain, May, 1882 (Thompson). (Qn'Appelle: Common sum. mer resilent; breeds; arrives May 12 (Guerusey).

\section{Cathartes aura. 'Turkey Vulture.}

Tolerably common in summer und probably breeding; frequently seen in tho led lifver region at the boundary (Cones). Wimnipeg: One or two observed (Hino). Red River Settlement: On the 27th of April, 1850 , the winter snow was covering the ground to the ilepth of a foot, while the rivers were still bound; the only part of the interior of 
British North America, as far as I can ascertain, that it inhabits in the prairie country that lies to the sonth and west of Lake Winnipeg (Blakiston). Portage la Prairie: 1884 ; scarce summer resident; first seen May 23; occasionally set $n$ in April and May, and again in September, generally near the Assin:boine River; not observed near the Red River (Nash). Tolorably common summer resident at Carberry; not known to breed; near Turtle Mountain; Fort Ellice; Cote's Reserve (Thompson). Two Rivers: Rare; two seen hovering over bank of river, May 2 (Criddle). Shot near Westbourue in 1881 (Macoun). Upper Assiniboine (Bell). Plains of the Souris near Pipestone Oreek (Hurd, July, 1858). Qu'Appelle: Common summer resilent; breeds ; arrives May 20 (Guernsey). Shell River : 1885, first seen, two, on April 25; here all summer at times, but not breeding (Calcutt).

In Minnesota, abundant; breeding. The Turkey Buzzard nsually selects the hollow prostrate trunk of a large tree for its nest. I found young birds nearly fledged as late as the 29th of July. There are usnally two young. occasionally but one This bird is capable of witustanding considerable cold. I saw it on the 24th of Octo. ber, and again on the 8 th of December. (T.M. Trippe.)

104. Elanoldes forficatus. Swallow-tailed Kite.

A rare straggler; observed in northern Minnesota near the boundary (Thompson). Occasional at Pembina (Cones).' Winnipeg: Accideutal visitant; rare (Hine). Noticed at Selkirk, Pembina Mountains, and Fort Qu'Appelle (Hunter).

105. Clrcus hudsonius. Harrier, or Marsh Hawk.

Abundant summer resident, chiefly in the prairie regions; common along the boundary from Pembina to Rockies; next found at Pembina (Coues). Dufferin: Arrived before April 15 (Dawson). Winnipeg : Summer resident; abundant (Hine). Spring of 1859; did not observe it before the 28th of that month (A)ril) nt Red River Settlement (Blak. iston'). Ossowa: Common; breeling, 1885; last seen, one on November 12 (Wagner). Oak Point: 1884, arrired April 27; 1885, first seen, one on April 8; is common and breeds here (Small). Portage In Prairie: 1s84; very common summer resillent; first seen April 11; bircls in the full blue plumage being occasionally seen; arrive enrly in April; ure abundant by the middle of the month; depart at the end of Uctober (Nush). Carberry: Our commonest hawk; summer resilent near Turtle Mountain; near Shoal Lake, west; the adults in blue plumage com. mon in spring and fall, rare at other times ('Thompson). Brundon: A pril 10, 1882 ('Wood). Common in the Winnepregosis region, but exeeedingly aloundant on the marsly prniries from Livingston sonthward ulong the Assiniboine, September, 1881 (Mncoun). Qu'Alpelle: Common sum. mer resident; breels; nrrives April 15 (Gnernscy). Alult male, Cum. Lerland Honse (Richardson). Severn House (Murray).

September 28, 1882: The full plumaged Gray Harriers are here once more. This birl comes earlier in the spring than the brown plumnged

harrier, flies diffe

On Oct flight; th the harri grass or : talons. beyoud $t$ ]

On Oc eatch sol the harri same tim several ti

On Ma undulater sounded chuck-ch ward line sigt.t. $\mathbf{T}$ long.

On iNa slongh. fixed my goillg ton straight $t$ bird had immenliat

It prov the gizza the harri for the $h$ swollell. saturated part of $t$ this illus

I have Manitob rows as solne yor by splas?

Miy 2 was exce lar, the rip-saw. much lik to boun 
ts in the innipeg it ; first Septem. the Rel rry ; not Reserve of river, Upper s (Hurd, arrives 25: here

is the holrly fledged ly lut one th of Octo-

poundary ccidental ains, and

common

Pembina 'innipeg : observe it nt (Bluk. Tovember soen, one Prairic: ils in the pril; are Oetober ar Turtle age com. oll : April ceedingly along the uon sum. ale, Cumn.

here once plumaged

Larrier, goes farther north to breed, migrates later in the fall, and flies differently, so that if it is the same bircl, the sase is a unique one.

On October 3, 1883, watehed a Blne Harrier capture a junco in full flight; the latter exhibited some extraordinary feats on the wing, but the harrier was always close behind, and followed up, down, into the grass or along, and in a few seconds he flew off with the sparrow in his talons. I am very sure the powers of flight of this hawk are much beyond those of a Brown Harrier.

On October 3, near Shoal Lake, west, saw a Blue Harrier trying to catch some teal that were on a very small shallow pond. Each time the harrier pouncel the teal would dire below the surface, and at the same time splash the water up as high as possible. This happened several times, and at length the baffled harrier gave up the attempt.

On May 13, 1884, saw a hawk tying over the slough with a deeply undulatel flight. At each ascending part it uttered a cackling which sounded like something between the shrill piping of a snipe and the chuck-chnck of a rooster calling the hens; then it dashed on the down. ward line, repeating the maneuvers for half a mile, when it was lost to sigt.t. This bird seemed black above, and pure white beneath; tail, long.

On iray 19 a harrier was sitting on a tussock in the middle of the slongb. It was ensily apyroached by an old and never-failing plan. I fixed my eyes on a point in the lorizon, which was so sitnated that by going towarl it I inust pass within 30 sarrls of the hawk. I then walked strigight to my mark, never turning my heal or even my eses, else the birl had surely flown. When at the nearest point I turned suddenly; immeliately the liawk sprang, but at once fell to $\mathrm{mg}$ gun.

It proved a female aud had a white breast and slaty-brown back. In the gizzard was a gopleer which had evidently been stealing wheat, when the hurrier caught and lyuched him on the spot. Certainly this is a plea for the hawk. Six of the grains were in good condition, though much swollen. They were planted but failed to germinate, donbtless becanse saturated with the harrier's gastrie juice, but most likely the greater part of the gopher's cargo was spilt where he was devoured, so that this illustrates one natural mode of distributing seed.

I bave male many other observations on the food of this bird in Manitoba, and all point to gophers as the staple, blackbirls and spar. rows as occaslonal varieties. I once saw an oll one trying to capture some young ducks, but the mother duck eontrived to keep him at bay by splashing until the ducklings escapel into cover.

May 20, saw a hawk tying in a most extranclinary fushion. Its course wins excessively undulated, with the ascending parts nearly perpendien. lar, the desceucling in a long oblique, the ontline being that of a huge rip.-saw. During the flrst upwarl bound it uttered w continuous caekling, much like the uote of a suipe, then plunged silently lownward, again to bound upward; when at the highest polut this time it turned a 
complete somersault, then plunge? again, and repoted this series of actions a number of times, then set its wings rigidly and sailed away il a straig"it lin, never flapping once till out of sight. It was a gray hawk with a white breast and seemed a perfect master of aërial navi. gation.

July 13, at the slough saw a hawk sailing about and squeaking like a snipe. It continued sailing very near and seemed in no fear of we, but of course I had no gun. A kingbird launched out frr., a bush and gare chase; the hawk rose higher and higher till tho kingbird was lost to sight; soou the latter returned and afterward the hawk. This happened twice and made me think it was a Red-tailed Buzzard.

As he did not seem disposed to go away, I went home and in half an hour returned with a gnn. He was still there and soon again came sailing and squeaking orer me. He made a swoop which brought bim very near; then crack! and he fell headlong. I ran to pick up my prize to find the Arctic hawk, at last, and lo! iny old friend the harrier, the commonest of our predacious birds.

August 9, I shot an adult female harrier at the same place as last taken. She also was uttering the peculiar cackling, though not fying after the manner described. Her gizzard contained a mass of pulp which was full of what looked like raspberry seeds. I think it likely she had swallowed a gopher whose stomach was full of that fruit.

On September 9, on the edge of the grain field, in the ovening, saw a bąrier (brown) pounce on a Prairie Chicken, but the latter struggled, and at length got free and made a dash for life, with the harrier in close pursuit, but to my surprise the chicken gainel at erery beat, and in less than 100 yards the harrier gave up the chase and turned about in search of gophers, grasshoppers, and other game more within his reacl..

The Marsh Harrier (Circus cyaneus hudeonius) is a very common birl through. ont Manitoba, and may often be seen salling over the prairies, the slonghs, or the wheat fields. One usorning late in August I remember counting a dozen rounil one house. * * Nearly all the individuals I saw were in the brown plamage; only three or fonr wore the ndult blulsh ash-colored dress. This bird connes often and insjects the setrlers' chickens, but seldom carries off nny except very young onesgophers, mice, aud grasshoppers belng its nsual prey. It Is exceedingly easy to shoot and one or two dend ones maj often be seen lying round a farmer's house. The harrier became a much scarcer bircl as September wore on (Christy.)

These hawks are very fond of eating the dncks that are killed and lost by sportamen, and where much shooting is done In a marsh you may see numbers of carcanses of ducks half devourea by this birl. On one occusion a harrier tried to take from me wounderl teal that liad crossed a creek on the bank of which I was shoo ing. Before I sent my dorg fo" tho duck the hawk came, hovering over the creek, and seeling the prostrate bird immediately pounced on 1:. back, but the tenl fluttered and threw him off for the moment. As I wished to see the result I kept perfuctly quiet, and the liawk, not noticing me, bottlel down on the gromul nbout 2 feet from the iluck and watched for some time; at Inst, apparently tired of waitiug for the wounded blrd to dle, he went off. These birds should never be destroyel; as, thongli occasionally they may take a joung or wounded duck, their prey is usually mioo and gophers. (Nivob, MSS.) 
series of ed away s a gray rial navi.

king like ar of me, a a bush bird was r. This rd.

d in half ain came ught him my prize rrier, the

ce as last not fljing of pulp it likely ruit.

ng, saw a trugglerl, uarrier in ery beat, al turned re within

dl through. 1ghe, or the 1 round one mage ; only ften and $\mathrm{ln}$ lung onesasy to shoot The har-

sportsmen, zarcanses of o from mo $n$ ng. Before d seoing the 1 and threw - quiet, aud om the lluck ountol biral occasionally nd gophers.

106. Accipiter velox. Sharp-shinued Hawk.

Summer residents of woodlands. Dufferin : Arrived betore April 15 (Dawson). Mouse River at the boundary (Coues). Winnipeg: Summer resident; tolerably cohi:mnn; April 15 to Uctober 15 (Hine). Speeimens in Smithsonian Institution ficm Red River Settlement, and from between Hudson's Bay and Lake Winnipeg (Blakiston). Portage la Prairie: Common in spring and autumn, bit not often seen during the summer'; arsires in April and departs in October; in 1884 arrived, tirst appearance, April 16 (Nash). Carberry: One takon October 5 (Thompson). Observed in Winnepegosis county; saw a number near Uoté's Reserve, and shot one at Livingston, September 11, 1881 (Macoun).

T.his andacions little robber is about the commonest hawk in the wooclet section about Portage la Prairie, bnt owing to his hiding propensities he is not 80 mnch noticed is the others. His usual habit of hunting is thus: He skims along low amongst b.xhes and shrubs, constantly alighting on the branches, and woe to the unfortunate spurrow or other susall bird that fails to drop into the grass before he arrives, for if the little bird is once seen it rarely escapes; for, unlike most hawks, this fellow will follow his prey through the thickest places, hopping and running after iim with the greatest rapility. I have, when quietly seated in the brush, been freq.iently warned of the approach of this hawk by the sudden cessation of song arouni me, and the utterance of a peculiar plaintive squeak by the small birds in the vicinity, upon which they all ilrop down aud hide, and in a moment my ghost-like friend glides like a shadow on the scene, drops on a low branch for a secont, nut then passes on. Sometimes, however, I luave seen this hawk strike at aut pursue a bircl in the air, like a truo falcon, and on one occasion an impulont villain of this specjes glanced past my hoad and snatehed up a plover I hul shot, carryiug it off in front of my dog's uose, and this ho did before the report of uy gun had died away, and throngh tho smoke from the charge. Tho net so nstonished me tiant I forgot to shoot at him until lie was too far off; when I did remember, 1 sent the other charge after him, but without effect; ho did not evon drop his ill-gotten spoil. On another occasion one followed a ro'tpoll almost into ms buggy. On the 22 l of August I saw one strike at a Bronzed Grackle and carry it off from where it was feeding in n public street, at Portage la Prairie, although there were many people about.

I have occasionalls seeu this bird hover like the kestril, but very rarely. (Nash, in IISS.)

\section{Accipiter cooperl. Coopor's Hawk. Chicken Hawk.}

Winnipeg: Summer resident; tolerably commou (Hine). I have seen them at Oak Lake, west of Brandon, where they breed; and suw a pair on 10th May, 8 miles south of Troy de way, west (R. H. Hunter). North to the Saskatchewan (Brewer).

108. Accipiter atricapillus. American Goshawk.

Tolerably common fall and winter visitant; usually appearing in August. Winnipeg: Winter visitant abunlant; November 15 to March 1 (Hine). Portage la Prairie (Nash). Carberry: Tolerably com. mon in fall ancl early wiuter; usually appearing in August; not noted during breeding season. Rat Portage: Fall (Thompson). A regular but uncommon winter visitor; more frequently seen near ti'o Red River near Winnipeg (Nash). 
On Aligust 27, 1883, George Measham brought a large gosbawk that ho had shot by the north slough; young female; length 24 , extension 44; weight, $2 \frac{1}{2}$ pounds good. It is a very big, heavy bird; legs, all reticulate except in front, where they aro scutellate; plumage very pale, streaked all over; a white line over the eye; its throat and stomach were filled with bad meat, but there was nothing to show of what kind.

On September 14 I secured a living goshawk by a curious combina. tion of circumstances. Some days before a harrier had been shot over at Wright's while chasing the chickens and was left where it fell; and on the day in questior the chirkess were picking at the now odorons body of their late for, he hree great gray hawks came wheeliug orerbead, and presently of of the m pounced down among the fowls. Away they ran for shelt three pirates circled awsy and hin $n$ onto the prairie to enjoy their repast, where, lo! to their infinite disgust, they found that the only chicken which had not fled was the dry and musty dead harrier. In the meantime I had starter after them with the gin, and by the never. failing trick of pretending not to see them, for there was not a stick of cover, I got within shot and secured a bird with each barrel. One of thein was only winged and after a short chase he was captured aud taken home.

Here I kept him for over a month, but finding that his wing was not likely to heal I kille $i$ him. During the time he lived he lost no whit of his inborn ferocity; he was kept chained by the entrance to the gar. den, and so far as hens were concerned he answered perfectly as a gate. He was always ready for a fight when any dog came near; but I found that by approaching cautiously I could seize his feet, after which he was powerless to inflict any injury.

The flight of this fine species is worthy of the true falcon, for it is so dashing and swift that the common buzzarls look very slow and clumsy in comparison.

January 13,1887, at Rat Portage, was shown the remains of a goshawk shot hero last fall.

I have seen these biris strike at Sharp-tailed Gronse and at tame pigeons, but they do not seem to be suocessful in their efforts very often, for I never saw them catch one nor do they appear to follow up their game after making their dash at it. (Nash, in MSS.)

\section{Buteo borealis. Red-tailed Mawk.}

(Possibly krideri, as a breeling specimen from Chippewa Lake, Min. nesota, is so identified by Mr. Ridgway.) Tolerably common summer resident of the wooded regions; one takf $n$ on Mouse River, at the boundary, in September (Uoues). Winnlpeg: Summer resident; rare (Hine). I saw numbers at Red River Settlement in the spring of 1859 (Blakiston). Portage la Prairie: Tolerably common summer resident, 
hawk that extension ; legs, all nage very and stom. pw of what

$s$ combinah shot over it fell; and w odorons. wheeling the forls. fff and the enjoy their t the only er. In the the never. $t$ a stick of el. One of tured and

ng was not ost no whit to the gar. $y$ as a gate. but I fonnd $r$ which he

a, for it is y slow and

a goshawk

ons, but they them catch it it. (Nash,

Lake, Milt. on summer rer, at the dent; rare IIg of 1859 r resident,

frequenting the skirts of the woods (Nash). Carberry: Oommon summis resident in wooded localitic s near hers; Duck Mountain, observed breeding (Thompson). Brau'on Hills: Nesting, Junis 4, 1882 (Wood). Sliot one fiue sprecimen at Livingston, September 13, 1881 (Macoun). Shell Rirer: 1885, frst seen, one, male, on April 5, afterward seen every lay; is a common summer resident, and breeds here (Calcutt).

By June 10, 1884, the Red-tailed Hawk was an abnudant specias in the Duck Mountain wooled region, much more so than the Swainson Hawk, which is the prevailing species on the prairie region of southern Manitoba. June 18, at Duck Mountain, shot a Red-tailed Hawk, female; length 20, exteusion 48. It seems to me to be the eastern bird, and not at all approachiug krideri. On July 9, as I drove with 'Dr. Gilbert past a part of the plain on which were a few scrub oaks, I saw a Redtail perched on a post. As we drew near he flew, but dropped a small animal; but before he could secure it he was attacked by another Redtail, and for some time their brilliant tourney in the air was an inter. esting sight. Again and again the uppermost bild would charge swiftly on the other, which would thereat alight on the earth and so avoid the onslanght, or if too high for that means of escape would, with a graceful sweep, tnrn on his back and strike upwarls with bis heavy feet. The combat was ended at last by the weaker taking refuge in all oa $:$. In the meantime I had stepped in and secured the boot $y$ which caused the strife. It was a very fine specimen of the Scrub Gopher (Spermophilus franklini), a rare animal; so it was thankfully recerved as an addition to ny collection.

This species seems to be the complement of Swainson's Hawk in Manitoba, adhering to the forest regions, while the latter is found only in the more open places. The differences of habit presented by these two species are slight but quite appreciable, and are of a class that, taken as a whole, incline me to lay down a law that no two species of animal have the same exact environment, aside from the hy pothetical fact that no animal fulfilling exactly the same conditiona would necessarily be of the same species. I find that each species, as it is further studied, shows that it is adapted to a set of conditions slightly different from those of its nearest congeners.

\section{Buteo lineatus. Red-shonldered Hawk.}

Rather common in the eastern or woodecl part of the province ( $R$. H. Hunter). One fine specimen shot on Oak Hills, November 3, 1881 (Macoun).

111. Buteo swainsoni. Swainson's Hawk. Common Henhawk.

Very abuudant summer resident in the prairie region. Very abundant 50 miles west of Pembina Mountains, at Turtle Mountain, and at Mouse River, along the boundary (Coues). Oak Point: 1884; arrived April 12 (Small). Winuipeg: Summer resident; abundaut (Hine). Port.

Proc. N. M. 901_-34 
age la Prairie; 1884; abundant; summer resident; first appearance in 1884, April 10; frequenting the open prairio and brceding in conspicuous places, usually in a small tree standing among low scrub (Nasł). Carberry: Very abundant; summer resident; breeds perhaps twice each season; arrives middle of April, departs middle of October; near Brandon, Long River; near Turtle Mountain; iu prairie region (Thompson). Two Rivers: 1885, first seen, one, on Marc! 11 ; next seen, one, March 14; pretty common and breeds here (Criddle). Dalton: 1889 , first seen, two, on March 22; next seen on March 23; is common, and breeds here (Youmans). Shell River: 1885, first seen, two, on April 9; afterwards seeu nearly erery day; it is common all summer and breeds here (Cal. cutt). Abuindant on the prairies along our route (Macouu). White Sand River; May 4, 1884 (Christy).

Several times I have been guided to a hawk's nest by the old ones themselves, who, in their tremor of anxiety for their young, have flown half a mile or more to meet me, circling high above me and uttering those long piercing screams, with an intonation of distress that was unmistakable. On one occasion, while trapping Gray Gophers (Spermophilus richardsoni) at a teeming colony of this rodent, a hawk flew repeatedly over me and back anu forth between me and an adjoining wooded slough. At first, I supposed I was trespassing on his hunting ground, especially when presently I saw him catch a gopher, and with it sail away so directly towards the trees that the inference of his nest being there was too palpable to be mistaken; I therefore followed him, and after a brief search discovered the nest in a low, dead poplar tree. Both old ones were screaming overhead, so that it was with cèrtainty of a prize that I proceeded to climb the tree. As soon as $\mathrm{my}$ head appeared on the level of the nest, one of the three young ones escaped, a second could barely fiy, yet it swooped ont aslant into the scrub, 20 yards away. The thirl could not fly at all. Thus it seemed that they were of different ages. The nest contained one gopher. The two young birds were secured with little trouble; at first, the only defense they made was gaping silently, with feathers bristling and wings spread forwurd; but on my trying to tie their feet, No. 3 seized a forefinger in each claw and so held them till the blood trickled from two or three places; he only let go his hold when I spread his legs and brought my knee to bear on his breast.

Mennwhile the old ones were careering overhead, and on the back of the lowest was a kingbird, whose silent diligence and energetic application to the task of plucking the hawk was most amusing. He took several riiles of over a huncired yards, and ultimately the hawk ap. proached so near to me that she fell to a charge from the gun. This proved to be the mother. Her gizzard coutained a Striped Gopher and part of a quaily ; the rest of the quaily was in her throat, with one foct in her mouth; so full was she that $I$ wondered how she was able to scream so much. 
arance in conspicub (Nas'). wice each ear Bran. compson). le, March first seen, eods here fterwards lere (CalWhite

old ones ave flown uttering that was ers (Sper. lawk flew adjoining s hunting and with ce of his 3 followed ad poplar I with cèr. on as my onng ones t into the it seemed her. The a only deand wings sed a forefrom two $s$ legs and

we back of c applicaHe took hawk ap. un. This opher and h one foct as able to
One of these young hawks was accidentally killed by a wagon, but the other throve in my hands and soon became reconciled to confinement in a barn, where in process of time he was joined by another of his own kind, a Peregrine Falcon, two Horned Owls and a Crane. Very soon the hawk evidently noticed a connection between my visits and his meals, and in a few days he learnt to greet me with an oft-repeated screan, much like that of the adults. His tameness increased nntil he would run screaming to be fed whenever he saw me. In a week or so more he could fly tolerably well, and was readily taught to come screaming and sailing about $\mathrm{my}$ head in response to the call, "Come, Dick." Then, after a performance of voice and wing long euough to give suffi. cient eclat. to the forthcoming grand flnale he would swoop past with the rapidity of at least a barnyard hen, and bear away my cup unless $I$ held up in my hand a bird or gopher, which he never failed to truss. One foot only was used for small birds, usually bis left, but if both gripped it was not at the same place, one foot being held far in advance of the other.

It is hard to say to what extent this bird might have been tamed, for during my absence for a week or so he reverted entirelv to his original habits, and was thenceforth but little better than the wild kinsman that shared the building with him. The history of this latter bird is worth relating. I was looking out of the window when I chanced to see a hawk alight on a feuce some 160 yards away; it was very con. spicuons, having a white head. This aroused my curiosity to know what strange species it was. I took my rifle and by a wonderfully lucky shot, which I could not repent for a kingdom, temporarily stuuned the bird, the ball barely grazing its crowu. It proved to be nn old one, and its head was white chiefly behind and more or less streaked with brown. When it revived it was placed in the barn and seemed well enough, but refused all food, aud for twelve days, so far as I know, it ate nothing. By this time it was reduced to a mere skeletou, but on the thirteenth day an idea seemed to dawn on it, and it made a hearty meal off a gopher, and continued well until one day the Horned $O$ wls, its fellow captives, were left with insufficient provender, whereupon they klled the hawk and devoured it to make up the leficiency. On a later occasion poor Dick received a similar sepulture.

The brood from which Dick was takeu, be it observed, was not able to leave the nest until July 24 . I have sereral times found the bird with one or more eggs ou May 20; have seen it settiug late May and carly June; on Juwe 26 I fouud a nest with four eggs, nearly hatched; and again on June 28 I found one with soung ones out and one egg not batched. On August 8 I was led by a pair of old ones to the nest, which at that time contained o: iy their youngest chick, then just able to fly a little. On the samed: one which was carryiug a $\mathrm{m}$ : sow lark presumably home to feed its 
young. So that these instances rather confirms the idea suggested by Dr. Coues, that this hawk may breed twice in a season.

As dready indicated, the habits of this species are those of a Red. tail which has betaken itself to a prairie life, and in consequence its nest is in a lower situation and its flight less lofty, while it is also frequently seen sitting on the ground. For plowed fields, in particular, it manifests a partiality, perhaps because amid such surroundings it can most readily see and secure the gophers which constitute its principal food.

The nest of this bird is not pecnliar. I have examined about fifty altogether, and have hitherto failed to find one that answers the published descriptions, which credit the bird with using a lining of hair and other fine material. All the nests examined early in the season were merely masses of sticks and twigs, with a slight hollow to contain the eggs, and had no special lining. But nests examined after the growth of the leaves-usually about the end of May-were more or less lined with twigs plucked with green leaves on them, and these when slightly wilted readily flatten down and form a wind-proof screen.

In general appearance this nest is much like that of the red-tail, but the position is different, being usually less elevated. I have seen many nests that I could reach from the ground. The favorite sites are the crown of a dense willow-alump, or the highest fork of a low scrub oak; occasionally I have observed the nest at a height of 20 or even 30 feet, in some poplar, but this is unusual.

The eggs are commonly three but sometimes four in number; they are more or less spherical and vary mucl, in color. The young, when hatched, are the purest and downiest looking of innocents, and it is only on examination of the tiny though promising beak and claws that one can credit that little snowball with the "makings" of a ruthless and bloodthirsty marauder.

The diet provided for them by the old ones consists of animal food entirely ; about $9 v$ per cent. of it, probably, being gophers and insects, and the rest composed chiefly of young song and game birds.

The name henhawk is a misnomer as far as this species is concerned. All the hen lifting I have seen done in Manitoba was the work either of the peregrine or the goshawk.

Auguat 5, 1882, near Badger Hill: On the way out here I got a tine buzzard; its crop was tull of grasshoppers and mosquitoes. (Wood.)

112. Buteo latissimus. Broad-winged Hawk.

In Ontario it is essentially the hawk of thick foliage and densest forest; very rare; summer visitant. Winnipeg: Summer resident; rare (Hine). Fort Garry (Ridgway). Carberry : May 12, 1884, saw what 1 took to be a Broad-winged Buzzard; did not collect it; havie not seen the specles here before (Thompson). 
gested by of a Red. ce its nest requently $r$, it mani. ; can most sipal food. bout fifty 8 the pub. ug of hair lo season to contain after the ore or less lese when reen.

d-tail, but seen many tes are the crub oak ; on 30 feet,

; they are ing; when it is only s that one thless and

himal food ad insects,

concerned. $k$ either of

puzzard ; its

nsest forent ; rare hw what I not seen

113. Arohibuteo lagopus sancti-johannis, American Rough-legged Hawk.

Migrant; common fall visitant. Less common in the spring. Winnipeg: Rare migrant; " have seen only three specimens in as many years;" 1884 (Hiue). Carberry : Rare in spring; tolerably common in fill; Rat Portage ('Thompson). Oak Point 1885; first seen, one, on April 7; next seen, April 3; becane common on the 10th : breeds here? (Small). Portage la Prairie: Oommon in spring; abundant in autumn (Nash). Received both from Severn House and Trout Lake Station (Murray).

Thls bird is far from being common in Manitoba. On the Big Plain I have seen only about a dozen specimens, and of these about one.fourth were in the black plumage.

Throughout the Assiniboine Valley, so far as noted, it is found only in the spring and fall. It generally appeared in the neighborhood of Carberry when the nights began to be a little frosty. The earliest I Lave observed was on September 9. This was a black specimen; it was perched on the top of the tallest tree in a wet place on the prairie; when it saw me, 200 yards off, it flew with heavy, flagging flight straight to the next slough, where also it took its station on the highest available perch. This fairly represents the action of all that I have noticed; they are very shy and frequent the trees in the neighborhood of swampy places.

Common in epring; abundant in antumn. Sometimes vers early in the morning, particularly if the weather should be cold and suisty, I have seen a dozen or more of these hawks at one time sitting about on the fence-posts or on the broken ground in the most listlese, dejected-looking manner possible. Having very seldom found anything in the stomachs of these birds, I fancy it is " a long time between meals" with them. (Nash, in MSS.).

\section{Archibuteo ferruginous. Ferruginous Rough-leg.}

Probably Manitoban; Pembina Mountain at the boundary; breeding; early in July, 1873 (Coues). I have seen a specimen that was taken immediately to the west of the province (Thompson).

\section{Aquila chryaätos. Golden Eagle.}

Very rare; possibly resident. Winnipeg : Rare; apparently resident (Hine). Red River Valley : Very rare (Hunter). Portage la Prairie: 1884, very scarce; not seen ly me (Nash). Big Plain (Thompson).

116. Falireötus leuoocephalus. Bald, or White-headed Eagle.

Very raro summer visitant; probably breeding; frequent on Red River from Mineheal to Pembina; several nests noticed (Cones). James Falls, Winnipeg River; eagles (Hind). Winnipeg: Summer resident; tolerably common; A pril to Octolser 1 (Hine). Rare; "reported to be frequently seen on Lake Manitoba" (Nash). Mouth of Waterhen River, a pair; one at Oathead, Lake Winnipeg (Hind). Common between lati- 
tude $62^{\circ}$ and Lake Superior; at Oumberland House March 24 (Richard 8on). Qu'Appelle : Occasional; does not breed; April 30 (Guernsey).

The couutry west of the Oninipique Lake has dry islands or hills with marshy bottoms full of wood and neadows. On the east side is a fine tlat country full of woods until they eone to the bottom of the mountains which are betwixt this and the upper lake. On a lake on that side, betwixt this lake and Lake $D u$ Bois, are the Migechichilinious, or Engle-eyed Indians; these, be says, are not called so from their baving a sharp sight, but upon account of many eagles, which breed in islands of that lake. (Dobbs, p. 35.)

On an island uear the month of the Waterhen River. " " We found a pair of Whitn-headed Eagles engaged in fishing, and as we came suddenly upon then after rounding a poiut, one of them dropped a fue whitetigh he had just caught, which was immediately soized aul approprinted ly onr men for their own breakfast.

On September 8, near Cathead Lake, Winuipeg, the party was reduced to great straits for provisions, when oue chancel to shoot an olil bald eagle. By eating nearly every portlon of the animal, except the feathors, we mannged to make him serve for two or three meals.) Hind. 1858).

Rare. On the 21st of March, 1885, Mr. 'T. A. Newman, of Portage la Prairie, showed me the wings of three of these birls that he had bought from an Inlian, who sail he had shot them south of the Assiniboine River. Mr. Newman also told mo be bail a year or two before shot one in full plumage on Lake Manitoba.

On tha 25th of October, 18s6, I sitw a splendicl bird in full plunage tlying sonthward just over the trees ou the bank of the Red River. (Nash, in MSS.)

\section{Falco ruaticolua obsoletus Black Gyrfalcon.}

Probably Manitoban in winter. Has been taken in Minnesota a few times as a rare winter visitant; a specimen examined by Mr. Ridgway (Cooke). The inference from Hearue's narrative is that he also took this bird at Cumberland Honse, and if so it was probably of the same variety as those takeu in Minnesota. Mr. Nash also reports seeiug a supposed specimen fly orer Portage la Prairie. This bird seems to follow the Willow Ptarmigau in winter; hence wo wonld expect to fud their southern ranges coincide.

They, like the other largo species of hawks, prey nuch on the white grouse or partringe, and also on the Amorican Hare, usually called here rabblts. They are always found to freyuent those parts whoro partridges are plentiful, and are cletented by the sportsmen, ws they getierally irive all the game off the gromad near their tents; lut, in returu, they often irive thither fresh flocks of some bundreds. Notwithstauling this, they so frejucutly balk those who are employed on hunting serv. ice that the governors generully give u sewurd of a quart of brandy for ench of their heads. Their flesli is always enten by the Inilians, and sonietimes by the Eugllsh; but it is always black, hard, and tough, and sometimus has a bitter taste.

The Indians ure foul of taming these birds, und frequently keep them the whole summer; but as the winter appronches they generaliy take flight and provide for themselves. When at Cumberland House I hud one of them, of which my people were reusarkably fond, ani as it nover winted for fool would in ull probability have $\because$ cainel with us all t'se winter, land it not been killou by an Indian who did not know It to be taine. (Heario.)

\section{The following from Hutchins seems to refor to this species:}

It appears in these parts in the montli of Mny, bullis a nest with sinull oticks, feathers, und clown, ties two last plucked frous its breast and lines the neat. It 
(Riehard uernsey). harshy bot11 of woods his and thes bis, are the from their ands of that

pund a pair opon then set canght, break fast. ped to great ting nearly in serve for

rie, showed h, who said ino he had

yiug south-

lota a few Ridgway also took the same 3 seeing a seems to ct to find

e grouse or They are re iletented near their reds. Notnting serv. or ench of by the Entaste.

the whole provide for my people dility havo ho did not

all sticks, nest. It

chooses a lofty tree for its residence. The young brood are darker than the parents ; they are commonly hatched about the latter end of July; it resorts to the plains ana marshes. It is perpetnally ou the wing, skimming along the surface of the earth, and preys on small birds, plover, and lucks. (Hutchins MSS., Observations on Hudson Bay, 1872.)

Falco peregrinus anatum. Peregrine Falcon. Duck Hawk, or Bullet Hawk.

Much like the goshawk in movements and distribution; probably breeds in the neighborhood of large lakes. Winnipeg: Summer resident; tolerably common (Hine). Portage la Prairie; 1884, rare; saw two January 1, 1885 (Nash). Carberry: Common in the late summer and early fall ; Boggy Creek, near Coté's, Uctober (Thompson). Two Rivers: Bullet Hawk first seen, oue, on April 4 (Criddle). Shot one nt Coté's Reserve on the Assiuiboine, September 22, 1880 ; I first watched it pursue and capture a Prairie Chicken (Macoun). Trout Lake Station and Severn House (Murray).

On Angust 11, 1882, about 10 in the morning, we had to drive away two Peregriue Falcons that were raiding in our poultry yard. In the afternoon they returued, and one of them made a most deternined effort to secure a hen, despite two shots fired at him. Howerer, he es. caped unhurt after the secovil lischarge. He did not stoop from aloft, lont skimned low over the ground in making his attack.

September 9, 1882. While standing behind the stable to day I hearl the turkey give warning, and immediately there was a whizz and a gray streak past me in the air; the ponltry sereamed and scattered, and I whistled and shonted just in time to turn the stoop of a Pere. grine. Again and again he dashed down and was with difficulty balked, and only by the time a gun was procured did he finally make off. Two days before I had found a hen with her head bearing three deep gashes, and I donbt not they were received from the claws of one of these marauclers, thongh how many of our poultry they really took I can not sny. I never suw any getually taken, and we never knew the exact census of the barnyari, so do not know how many, if any, (lisal) jeared.

On the morning of September 18, I saw a Peregrine sitting on the felice, but he flew before I could get a shot ut him and circled away above the barn, incrensing his elevation ąt each gyre until about at the third wheel, when at a height of 200 or 300 feet he suddenly stopped, half elosed his wings, and lived headlong into a fleld half a mile away. His descent was at lenst as rapicl as the fall of $n$ stone would have been, and as he swooped his wings were slightly and slowly expanded and closed again a number of times. What his victim was I never knew.

On July 20, 1884, necured a Peregrine in first plumage. This was shot by Mr. Gorlon Wright, near Curberry, und sent to me. He desoribed it us the "swift gray hnwk;" it was raiding in bis poultry yard, whell he rau with his gun to the rescue and rapidly fired, but the swiltness of tho bandit naved him ench time for four shots, and he 
fiercely and determineilly continued to dash around the buildings in pursuit of the fowls, when a fifth shot grazed his wing and brought him down. He is the very personification of tierceness and defiance, and his actions are full of snap. As soon as approached he hissed, and struck with his great talons so quickly that the eye could not follow the movement. I put him in a buililing along witl a Swainson's Buz. zard and a crane, and, oh! how clumsy and vulgar they both lookel beside him. He is the royalest robber that erer I saw. His erery mo. tion is so full of untamable ferocity as to elude the eye; his eye is brighter and fiercer than an eagle's, but I am in hopes that with care I may succeed in taming him. August 2: Notwithstanding the gentlest treatment, the Peregrine continued to scorn all approaches, and the slightest attempt to touch him called forth in response only tho dim flash of his massive horn-tipped feet, a fair warning of what may be expected should the liberty of handling be attempted. On enteris.g in the moruing, I found him sitting on the body of the crane; it is not certain that he was the murlerer, but it is against him, that having left him unlisturbed for an hour immerliately afterwirl he made use of the time to devour the greater part of the erane's breast on one sile, and that he and the buzzard subsequently picked tho bones clean. Angust 12 : The Peregrine diel to-day, after a captivity of three weeks, no canse being assigned for his death. He was a young unale of the year, I think. Besides tho hissing menace already mentioned, he indulged in two other vocal eftorts; one an exceedingly loud, piercing screan of anger, the other a reiternted sl:rieking, ulmost exactly like that of the kestrel. but stronger and in a deeper key.

Pay-pay nay seu Ka cake. " " They appear in our marsies in tho beginging of June, anil soon after mako thoir nests in trees. It is composed of sticks and liued with feathers. Thoy lay three or four white eggs. The young ones take flight in Angust, ind the whole species leave us in September or the first week in Ootober. They sometimes kill geese, bnt their nsual fool is ducks; plovers, partridges, and suall birds. (Hutchins MSS., Oloservations on Hudeon Bay, 1782.)

Ou September 11, 1083, at Carberry, about 4 p. m., a fine Peregriue came and sat on a fence close to the house. Just as I was about to fire at him with the ritle he rose and flew elose over my heul and aronnil me. Then, after whisking over the chickens and pntting them juto a ruro fright, lo hovered for nearly a minute at about 40 feet abovo the groubl as well an over I otw a kestrel do, which surprised mo. So stationary was he that I thought I might as well fire, as I had as good a chance of hitting him as on a fence. I lid so, but of course mlesed hin. (Christy, lu MSS.)

\section{Faloo columbarius. Pigeon Hawk.}

Ohiefly in tho migration; common. Dufferin: Arrired before April 15 (Dawson). Winnipeg : Summer resident; tolerably common (Hine). Onsown: 1885, April 18; comuon April 23 (Wuguer). Norway House (Bell). Comenon fuli migrant at Cirberry; noted also north of Petrel (Thompson). Ono shot at Livingstou, September 13, 1881; common in Wiunepegosis regions, breeding in ths Assiniboine Valley, at Brandon, 
dings in ght him ace, and sed, and te follow n's Buzlooked rery mo. $s$ eye is th care I gentlest and the then dim may be enteriıg it is not ving left se of the ide, and Augnst eeks, no he year, indulgeil cream of it of the

beginning and liued Dight in October. dges, and

und ant on le be rose chickens ut 40 feot - So stscee of hit(SS.)

re April (Hine). y House f Petrel nmon in randon,

and along the Qu'Appelle Valley (Macoun). Qu'Appelle: Tolerably common; arrives April 20 (Guernsey).

Un September 9, 1883, a flock of five or six l'igeon Hawks came about the farm buildings. In general manners they were much like Sparrow Hawks, but they sailed more and flapped lass. They were of course larger, and seemed more stoutly built; their duller color also was a distinguishing mark.

One trick of flight they had in common with the Whisky John, Shrike and others, namely, flying low over the ground towards a pos: or stump, and just us oue expects to see them strike the bottom of it there is a sudden spreading of tail and wing, and the bird gracefully bounds straight up to the top and alights there. This species will sometimes hover, though they do not make such a practice of it as the Sparrow Hawks. This maneuver I have also observel, though in a still less de. gree, in the Peregrine. One collected was a female; length 12, extent 25. All above was dark brownish gray; all below, buff heavily streaked. W'ings and tail show but few marks abore; below are spotted with buff; in crop, a sparrow; in stomach, another. This bancl may have been a single family returning from their breeding place in the wooded mountains to the east.

\section{Faloo riohardeonit. Richardson's Merliv.}

Very rare. One taken at headwaters of Mouse Rires, Dakota, near the boundary (Coues). Shot at Fort Pelly in September, 1881 (Macouni).

121. Faloo aparveriun. American Sparrow Hawk. .

Abundant summer resident; very abundant from Pembina along the boundary to the Rockies (Cones). One from between Hudson's Bay und Lake Winnipeg; one individual at Red River settlement on $22 \mathrm{~d}$ April, in 1850 (Blakistou). Wimnipeg: Summer resident; tolerably coumon (Hine). Oak Point : 1884, arrived April 20; 1885, first seen, one, on April 15; is common and breeds here (Small). Portage la Prnirie: 1884, abuulant summer resident; tirst appearance April 26, departing in October (Nash). Carberry : A bundaut summer resident wherever there is large timber (Thompson). Very common; breeding along Red Deer, Swan, and Assiniboine Rivers; throughout the Winnelegosis region and in the various streams and valleys of the Nortliwest risited in 1880 (Macoun). Shell River: 1885, first seen, one male, on April 14; a transient visitant only (Calcutt). Qu'A Appelle: Common; summer resident; breeds; arri zes April 15 (Guernsey).

On July 26, 1884, while traversing the Carberry Swamp, I heard the loud, reiterated screeohing of the kestrel, and on looking upwards saw one of these andneions birls following and dashing uround an engle, and endeavoring by every means in his power to intimate to the latter that his lifo was in imminent jeopardy-that, indeed, it was not worth a moment's purchase unless he instantly left the neighborhond 
of his (the kestrel's) nest. When last I sa.7 them over the trees, the eagle had apparently accepted the terms, and the kestrel was plying bin with sundry sayings and maxims while he saw him sa'aly out of his neighborhood.

In August they gather into omall parties and hover abont over the prairie, feeding principally on grasshoppers, thongh they are yuite capable of capturing hetter gane. On two occasions I have seen them kill and carry ofl uneadow larks; these I shot in the act. Another time I found tho remains of a red squirrel and a purple finch ia the stomach of ono, but the most extraordinary foat I ever eaw one nttempt was its attack on a crow. The hawk struck viciously at the crow, knocking hiu down into the road just in frout of iny house; the hawk diopped on the fence just over his illtended victim, and sat there while tho poor crow squatted close to the ground will his winge and tail spread out and month wile open looking the pictmo of terror. I had pulled up to watch the ontcome of tho performance, bnt unfortmuately my horse moved and attracted the attention of the parlies to the duel and they hoth flew ofl in opposite directions. The hawk conld harlly have been driven to this bold act hy hunger as it was late in the spring aud there wero uumbors of amall birds about.

Early in the moruing of Algust 31, I siaw a party of tive or six of these hawks and a single Sharp-shin eljoying a regular roup around a deserted house on the prairie. They chased and dodged ench other round aud round the building, settling when tired on the roof aud chimmeys. The Sharp-shin took his turn with the rest in chasing and being chased, tho wbole game apparently being curried on in the most frlendly spirit by all parties. I watched them for ovor half nu hour and left them still at it. (Nash, in MSS.)

At Carberry on September 7, 18\$3: In the morning I found a considerablo nssembly of American kestrils ( $T$. sparverius) round a small eluster of aspens aloout a miles north. I severul times saw one of them chasing meadow larks, but with no success, apparently. At one tino I got into quite a flock of them, twenty-five or thirty nt loast, and shot three, one fine old one, male, and two young ones hoth of which haul only grusshoppers in their gizzalds. All dny they were round the house hovering und chattering just like the English kestrel, and sitting on posts and building quite tamely. I ran out of amninuition or conld have shot lots, so tame ancl numerous were they. They must have some uigration on hand as I have nover before seen them so numorons, thongh sometimes I have seen singlen ones around tho honse." * - September 8. Kestrels aro still about, but not in meh largo numbers. I slsot another nice old malo with plonty of grasshoppers ancl other insocts in his gizzarl. September 10. Kestrels are still fairly ummerous abont tho promises and one wns in the garden catching grasshoppers nmoug the potatoes a good many tines during the day. (Christy, in MSS.)

122. Pandion haliaëtus oarolinensis. American Osprey, or Fish Hawk.

Rare summer resident; Jumes Fulls, Winnipeg lRiver (Hind;: Winnipeg: Summer resilleut; rare; Shonl Lake (Hine). Red River Vul. ley: Summer resiclent; rare(Hunter). Common, nests along the Churchill and Grass Rivers (Bell 1880). Very rure; one seen over the Assiniboine? Jivar at Portage la P'ruirie, on Muy 11, 1885 (Nash). Saw it on the lakus be'it al Porcupine Mountain, and in the Winnepegosis region; saw nest in u ree on n rocky point (Wilkin's) Lake Winnepegosis (Macoun). Whell River: 1885 ; iq a common summer resident and breeds in:? ; fl: sen $n$ A pril 4; afterwards seen every day (Calcutt). Oeca.

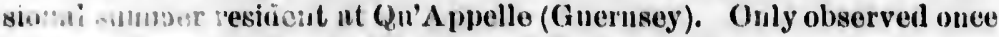
or i wen (bec iveen .Norway Ihuluse nucl Carleton) (Blakiaton). 
rees, the ts plying ly out of

ie, feeding etar ganue. $\theta$ I shot in o finch in pt was its down into ver his in. ound witl terror. 1 ing horse (h flew ot old act by about. hawks and he prairie. ling when the rest in a the niost left them

lo assembly out a inilt. no anceoss, c thirty at which has o hovoring lding quilo numerous veforo seen house. rs. I sbot is gizzard. one was in during tloo

Hawk.

1!: Winiver Vul. Churchill siniboille it on the region; repegosis al breeds ). Oechl. rved once

\section{Asio wilsonianus. Ameriean Long-eared Owl.}

Tulerably common summer resident. Wiunipeg: Summer resident ; tolerably common; arives April 1, departs Norember 1 (Hine). Solitary; hunts at night; Red River region (D. Gunn). Has been seen in the wooded country east of Winnipeg, during February (Hunter). "Screech Owl," Ossowa (Wagur). Portage la Prairie: Rare summer resident in this locality; near Winnipeg only five shot in six years (Nash). Carberry : Summer resident; not rare; breeding (Thompsou). Two sinecimens procured at Fort Pelly, September 16, 1881, and one at Birtle, Uctober, 1881 (Macoun).

On July 10, 1884, found a nest of the Long-eared Owl in the middle of a dense bush of low red willows. It was not more than 9 feet from the ground and yet very difficult of acess, for the willow branches were too slender to bear my weight, and as tisey chanced also to bo oi dead wood they could not be bent down without endangering the nest. Therefore, to make elose observations, I lifterl a sınall boy on my shoulders, so that he was able to reach and hand me the contents of the nest.

The nest itself was composed entirely of sticks and was much like that of a hawk. It was not the old nest of a crow, or of any other bird that commonly builds with sticks, so that $I$ ain satistied that it was the owl's own work. At this time it contained four young ones, and these were evidently of four different ages, one being half-grown and nearly flerged ; another seemed to be only two or thrce days old, for it was yet a tiny ball of white down that the eller one might easily have swallowed. The others were in different stages between these. Each of the nestlings as it was handled snapped its bill with vigor proportioned to its size. The mother bird hud appeared soon after we arrived, and althongh it was a bright summer day, she did not seen to $l v$ at all inconvenienced by the light, but flew around us with all the assurance of a bird that is usually diurnal.

When we approached the nest she became much excit's and either flew round and round us or alighted close over our heads, and snapped her bill loudly and often, while from time to time she uttered a loud long ury like "on-il-il-il-il-il-il-loo."

Having completed my examination I left her in peace, intending to return again in a few days to note the growth of the birls; but som? one came before me, and when next I went the nest was empty.

Cn the night of Angust 25 I heard a strange shrieking, between the cry of a fox and $n$ eat. It seemed to come from the barn where my Horned Owls were confined. I took my gun and went out. After waitling and watching for somis minutes $I$ mude out the form of a large broad-winged bird, flying around the building and uttering the wild somnd I had noted, in response to the querulous notes of the owls within. When I mimicked its note it flew over me, and was at once 
"collected." It proved a Long-eared Owl. The long note that I heard from this owl is decidedly musical, but the cries heard at this time may be best described as unpleasant shrieks.

Amisk-oho or Long-eared Owl of Pennant. This species is found, thongh not frequently, at Severn Settlement. * * " They inhabit the woods at all s"asons, a considerable distance from the sea ; seldom to be fonnd within the day, but ju the night approach, when a clamorous noise proceeds from tents. They breed in trees, lay fonr white eggs of an elliptical form in April, and their young fly in the latter oud of May. N. B.-This bird is looul. (Hutchins MSS., Observations on Hudson Bay, 1782.)

Have never seen them in the winter. They always disappeared at about the tiute the first snow fell, with the short-eared species. Their flight when hunting during the day always reminded me of the harrier, which it closely resembles. (Nash, in MSS.)

124. Asio accipitrinus. Short-eared Owl. Marsh Owl.

Tolerably common, chiefly in early autumn; probably breeding. Winnipeg: Summer resident; tolerably common; arrives April 1, de. parts November 1 (Hine). Portage la Prairie: Abuniant summer resicient; most often seen in the fall, especially about the marshes in August and September; never seen in winter; arrives early in April, departs late in October (Nash). Carberry : Not uncommon in Angust and September (Thompson). Brandon: April 18, 1882 (Wood). Abuudant on Westurn Plain, 1880; two specimens procurenl on Assiniboine River below Shell River, September 24, 1881 (Macoun', Trout Lake Station (Murray).

August 18, 1883. Luring the month we have often see:i owls that appear just about dusk and winuow over the prairie to the vest of the house; now high and sharp against tho last bright streak of day; now down, to remain lost against the dark earth; and if agaiu rising after some time from that same place, we know that pounce brought death and burial to some foraging field-monse or dissipated small songster. I suspect that this species is either tho Long.eared or Short-eared $O w$ l. This eveniug one of these mouse-hunters came careering ubout the barus with evident intent to dabble his rery soul in arvicoline gore. Mr. Christy's gun was ready and he had one suap shot, but the owl flew off to the rorthwest over the grain fleld, but lower we thought as he disuppeared. Night and a rainstorm came together and prevented our following.

August 19. A heary rainstorm all day.

Angusit 20. Tuis morning the rain ceased. About 10 o'clock we went out in the direetion of the owl's course. We had almost persuaded ourselres that wa saw the birl go down by an old strawstack fur out in the field; so on the mere chance we went to this place, and almost immedintely up sprang the owl, but at once he was "collested" by the sid of the ready double-barreler, and there he lay on the grass, whenutiful specimen of the Short-eared Owl. His plumage was in perfect orler and his horns wore remarkably prominent; this, however, was lost

after he hn is the owl's this bare 0 only injuris several sim

This spe 162 square a single la the ground

The shortand Septemb never seen tl yoar in thei clined to this

On the 18t marsh and rose high in Hawk. I be rising from

Early in $t$ for somo tim suapping no being the on or a log imb

Rare an arrives $\Lambda_{l}$ erably con also been : near Rat ] Very rare heard the (Nash).

Rare wi Settlemen as $n$ wlnt Septembe

Ou Sep Owl whisl length 25 , inclies, $i$. turkey vu mote corn cooperif) 
I heard his time

h not fre8"asons, a but in the 1 in trees, the latter n: Hudsou

the time ng during (Nash, iı

reeding. fil 1 , de. summer arshes in in April, August (Wood). II AssiniTrout

wls that ist of the ay; 10 w ing after ht death songster. red Owl. bout the ine gore. the owl ought as revented

we went uled our. in out in inost Im. " by the a benu. perfect was lost after he had been handlea. The curious circumstance of this incident is the owl's persistently remaiting during a forty-hours rainstorm on this bare open place while powers of flight were unimpaired, and his only injuries apparently a slight flesh wound on the wing. I have noted several similar instances among hawks and owls.

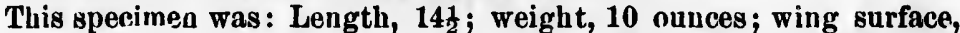
162 square inches, or $16 \frac{1}{5}$ to each ounce of weight. In its stomach was a single large brown cricket (Udenpsylla nigra), no doubt captured on the ground whise we found him.

The short-eared owl is a great frieud of mine; he tnrns up regularly every August and September in che marshes and meadows both in Ontario and Manitoba, but I have never seen them is the spring or summer, and as I opend most of my time during the year in their favorite haunts, and wever see them nesting or about, am strongly inclined to think they do not breed in the province, nor do they stay during the winter.

On the 18th of April, 1885, at sunset, a large number of these birds came out of the marsh and quartered about over the prairio. One of them, however, after a time rose high in the air and played about over a slough much after the manner of a Night Hawk. I believe it was catching on the wing some of the aquatic beetles that were. rising from the water at the tine.

Early in the morning of the 25th of April one of these owls circled ronud my bliud for some time, frequently striking its wings together over its lnck, producing a lond suapping noise. The same bird eoveral times perched ou a fence rail near me, this being the only time I ever saw nue alight ou auything higher than a muskrat house or a $\log$ imbedded in the mud. (Nash's MSS.)

\section{Byrnium nebulosum. Barred Owl.}

Rure and probably migratory. Winuipeg: Summer resilent; rare; arrives $\Delta$ pril 1 ; departs November 1 (Hine). Red River Valley: Tolerably common in the wooled country east of Winnipeg, where it has also been seen in February (Hunter). Was shown the wings of one shot near Rat Portage in the full of 1886 (Thompson). Portage la Prairie: Very rare, ouly one seen near the Assiniboine, but I hare occasionally heard them hooting in the wonds on the bank of the river in August (Nash).

\section{Ulula chnerea. Great Gray Owl.}

Rare winter visitant; one in Smithsonian Institution from Ked River Settlement (Blakiston). Found along Red River and at Lake Winnipeg as a winter visitunt, but not common (Hine). Carberry: One taken September 29, 1884 ('Thompson).

On September 29, 1884, received from George Mersham a fine Gray Owl which he had shot in the woods to the south. It was a young male; length 25 , extension 54 ; weight, 26 ounces; wing surface, 480 square inches, $i$. e., $18_{13}$. to each ounce of weight, nearly twice that of the turkey vulture shot yesterday; tail surfice 100 square inches. In a remote corner of its spacious stomuch I discovered a tiny shrew (Sorex

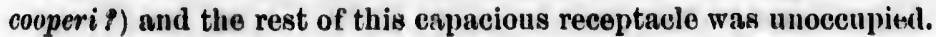


In the wooded sections probably resident. Winnipeg: Winter visitant; tolerably common; probably resident (Hine). Selkirk Settlement in February and March (D. Gunn). Two Rivers: On February 7, 1885, shot a pair of Richardson's Uwls (Criddle).

On June 11, 1883, at the sprnce bush I found the reinains of a specimen of Richardson's $O$ wl. This was shot in the spring by one of the mill hands and left where it fell.

Febrnary, 1885, Toronto: While at Winnipeg last month Mr. Hine showel me several dozen specimens of this bird, all taken near the eity within tlıree months.

\section{Nyctala acadica. Saw-whot $O w l$.}

Rare, resident. Noted only on Red River: Rare; probably resident; only two seen at Winnipeg up to 1884 (Hine). Red River Valley: Resident (Hunter).

Shipo me shish: Small Owl. This is the smallest owl in Hudson B.g nearly, corresponding to the small owl of l'ennant. It woighs $4 \frac{1}{5}$ onnces, the length $8 \frac{1}{2}$ juebes, the brealth $: 0$, irides bright yollow; feet and legs foathered, and talons black. * * It lives among the pines in all sensus, feeding on mice; only unilds a nest of grass half way up a pine tree in the moallu of May, lays two white eggs, aud the young fly in the heginuiug of July. They are not plenty and are the nost solitary bird I ever knew, seldom moving in the daytime, but a brisk monser by night. They never ehange color. It is common for the Indian children to steal toward them in the daytime and seize them. (llutchius MSS., Observations on Hudson Bay, 17 K2.)

Mr. Hunter claims the Screech Owl (Megascops nsio) for Manitoba, saying: "I saw a pair at Saboskong Bay, Lake of the Woods, and in 1871 heard them at ?oint du Chene."

129. Bubo virginianus subarcticus. Western Horned Owl.

Common resident wherever there is timber. This form of $B u b 0$ is lighter in color than the true Bubo virginianus subarctious. It is probably just intermediate between that form and var. arcticus. Pembina: Breeding (Cones). Winuipeg: Common resident throughout the year (Hine). Red River Valley: Permanent resident; more seen in winter (Hunter). Swampy Island: 1885̄; common resident; breeds near here (Pluukett). Observed breeding (Wagner). Portage la Prairie: Common resident but somewhat migratory (Nash). Carherry: Common resilent; breeding; Rut Portage; Duck Mountain; Assissipi (Thomp). son). Two Rivers, November 12, 1885 (Uriddle). Shell River: 1885; winter visitant (Calcutt). Fort Ellise: October, 1880 (Macoun). White Sund River: May 5,1887; lesting (Christy). Qu'Appelle: Occasional; uot common (Guernsey).

September 18, 1884, Portage la Pruirio : Mr. O. W. Nas! gives me a very interesting note on a pair of Horned $O$ wls that had nested in the wools here, anil from the indications observed there seems little donbt that suliall creel boine Rivel pair which there were, fish with or being very run betwee the circums torial purs

On the 8 of an old ny Big Plaiu. of a popla formed of Red-tailed nest, but 8 even in the determined place we f watch, whi had not $\mathrm{g}$ skimming As the dar shouting a you-dop" " inspection, suapping And stric they dash doion," " 0 I fired and inches acr tained par of the Sn partriilges cgg ready withont ar

The you weighed 1 One of the down, wit wings ant of down $t$ They re them from 
loubt that they subsisted chiefly on fish, which were abuudant in a small creek running from a lake through these woods to the Assiuiboine River. On examining the gizzards of two of the young of this peir which Mr. Nash shot, he fonnd them full of fish. At one place there were, unquestionably, evidences of an owl having seized a large fish with one foot and held on to the bank with the other. The creek being very small, and surrounlell with large bare trees, is a favorite run between the river and the lake for large fish at night, so that all the circumstances are very favorable for the prosecution of the piscatorial pursuits of the owls.

On the 8th of May, 1884, I found a pair of these birds in possession of an old nest in the Big Siramp on the Assiniboine River, south of the Big Plain. This nest was about 30 feet from the ground, in the crotch of a poplar tree, which was as yet without leaves. The nest was formed of sticks and twigs and was indistinguishable from that of a Red-tailed Buzzard. Once or twice I tried to shoot the old bird on the nest, but she was too wary, and evidently had all her wits about her eren in the day time. On the 15th of the month I returned to the nest, determined to bring home whatever might be in it. Arriving at the place we found the old birls were absent, so I stood with the gun to watch, while Dr. Gilbert, who accompanied me, climbed the tree. He lad not got half way up when the old ones mide their appearance, skimming about among the tamaracs and hooting "who.who.are you." As the danger to their brood increased they came nearer and nearer, shouting and stammering with rage "who who-vho-are.you" "What.do. you-do" " "Up a trec." Then, having loarned it seemed, from their close inspection, the magisterial function of the climber they wheeled off, smapping their bills and groaning aloud "Oh.k.h.h $J P$ up.a.tree!" And stricken by the hopelessness of their case in this new aspect, they dashed about shouting hoarsely "Oh.h $h$," "Go down," "Do go down," "Oh.h.h _ , and as one of them recklessly flew close to me, I fired and it fell. This proved to bo the female; she measured i3 inches across the wings and in length 25 inches. Her stomach contained part of a partridge. In color she was as light as young females of the Snowy Owl. In the nest were three young owls, two dead partridges (Bonasa), aud a hare; one of the partridges hail in her an egg ready for exclusion, excepting that the shell was as jet pure white without any spots.

The young oues appeared to be about three weeks old. The largest weighed 1 pound 5 ounces, and was abont the size of an ordinary pullet. One of them was but half as large as the others. All were clad in white lown, with the rudiments of black and white feathers showing in the wings and on the back. Their horns were plainly visible In the form of lown tufts.

They resented in the orthodox manuer the liberty taken in removing them from the nest, snapping their bills and hissing in a way that 
would have distinguished much older birds; but as they did not attempt to use their formidable talons, we did not suffer much inconvenience from their menaces. One of them liad been injured, and died before we reached home, the others throve and readily ate from our hands from the first. They solicited food by a short scream very like that of a Night Hawk; they monaced by snapping their bills and hissing, and expressed surprise and anger by a querulous whistle.

By the time they were about two months old they were fully fledged and could fly fairly well. In general color they were pale buff with black bars; a little lighter than the typical Bubo virginianus, but con: siderably darker than the mother. At this time the horas were less conspicuous than when in the down.

They ejected a pellet about five times per week, and if supplied with more food than required for present use they hid it until they were hungry.

At first we (Dr. Gilbert and myself) were in hopes of taming them, but their ferocity grew with their growth, and when they were able to fly, so far from submitting to be haudled it was not safe for a stranger to come near them. No better illustratiou of their strength and flerce. ness could be given than the fact that, on one occasion, when they were left without food for a longer time than usual, they killed and ate a fine full-grown Swainson's Buzzard, which was confined in the same barn with themselves; and subsequently they did the same with another bird of the same species, which I had always thought strong enough and quick enough to take care of himself.

At the age of 10 weeks a perceptible change in their plumage began to take place; the bufify feathers of the breast gradually giving place to the pure white of the old birds, amounting ulıost to a transition from the $B$. virginianus form to that of the $B . v$. arcticus.

They continued to grow until they were nearly 6 months old. Their appetites were large and very fastidious, for they would eat half a pound of meat per day each, and would relish only such as was per. fectly fresh.

Towards the end of October they seemed to have ceased growing and were contentel with smaller rations; their horns were fully developed; they had made their first attempt at hooting, and otherwise manifested their conviction that they now were able-bodied owls on their own account.

In November I was so much from home that they did not get more than 3 meals per week, and it was useless to give them a large quantity of food at a time, as it froze to a stony hardness in a few minutes; therefore, as I could not feed them properly, I thought it better to kill them. When the first was quieted, he proved on examination to be excessively fat, notwithstanding his inouth on short allowance. Under these circumstances sentence on No. 2 was commuted. However, a storm tore open his honse; he escaped, but continued ubout the build-

ings, whicl during whi starvilig as

MIy ampl culptivity a: seen of the their magui orous taste pronounced

Natow okes ing on mice, yiue tree, wi tako to tho w

Comurn re alwuys for so winter they 1 abuniant in day; after th

Thoy vary specilicus ; t seen anywle them. (Nas:

One slot wood Hills

Tolerabl ably comm a winter vi pass the $\mathrm{s}$ there in sl Prairie: $\mathbf{R}$ season (N:1 Ureek, Big on March mon (Guer

Wa-pa-cumakes a nes Bay, 1782.)

During the day; two or were less nu as in the last probubly fou Feloruary or Pro 
attempt venienes d before ar hands $e$ that of ing, and

\section{fledged} onff with but con: vere less

lied with hey were

ng them, ce able to stranger nd fiercehey were ate a fine ume barn another g enough

ge began g place to tion from

d. Their at half a was per-

growing lly devel. ise mani. on their

get more quantity minutes; er to kill ion to be - Under owever, a he build- ings, which were 2 miles from the woods. After a month of this life, during which ho received no food from me, I shot and found him, not starving as I expected, but finlly as fat as his brother had been.

My ample opportunities of filly observing these interesting birds in cantivity as well as in a state of freedom, and indeed all that I have seen of them-their untamable ferocity, which is daily more apparent; their magnificent bearing; their objection to carrion, and strictly carniv. orous tastes-would make me rank these winged tigers among the most pronounced and savage of the birds of prey.

Natow okey ornis seu: Horned Owl. 'This ologint lind harbor's in the woods, feeling on miee, wild fowl, and carriou. Abont tho midalo of March it builels a nest in a pine tree, with a fow sticks latil across, and lays two whitish eg'gs; tho yonng ones take to tho wing in Juno. (Futehins MSS., Observations on Hnclson 13ay, 178i.)

Common resident; but I am sutistied this bird is somowhat migratory, as thero is always for sometimo in tho fall a large increase in their number; at the approach of winter they becomo less nnmoroms. I noticel this every season. Thoy are almost abunlant in October on the Red liver, fonr or fivo lowing soen by mo nearly every dity; alter the cold weathor set in the great majority of them disappented.

They vary much in plinmage, ranging from vory dark to extromely light-colored specinuns; two young birts I shot Angust 9, 1854, being the two palest 1 havo evor seeu anywhore. Another bird that was with these two appeared quite dark besido them. (Nas 1, in MSS.)

\section{9a. Bubo virginianus arcticus. Arctic I Iornod Owl.}

One shot near Duck Mountain in the fall of 1583 (Thompson). Touchwool Hills : October, 1880 (Macoun).

\section{Nyctea nyctea. Snowy Owl. White Owl.}

Tolerably eommon winter visitant. Winnipeg : Winter visitor; tolerably common; arrives September 20, departs $A_{\text {pril }} 20$ (Hiue). Merely a winter visitant in the districts to the west of Lake Winuipeg; a few pass the summer near Lake Winuipeg, as occusional birds are seen there in spring and fall (D. Gunn). Ossowa (Wagner). Portage la Prainie: Regular winter visitor, appearing in varying numbers each season (Nash). Carberry : Regular winter resildent; Melbourne, Boggy Ureek, Big Plain ('Thompson). Brandon: February 2', and a female on March 5 (Wood). Qu'Appelle: Have seen specimens, but not com. mon (Guernsey).

Wa-pa-cu-thu, or Spotted Owl. " * "This bird is an inhabitant of tho woods; makes a nest in the noss on dry grouud. (II ntehins MSS., Observations on IIndson IBay, 1782.)

Buring the winter of 1882-'83 thoy woro very common. I saw some almost overy day; two or three perfectly whito ones anongst them. In the winter of 1883-' 44 they . were less unmorons; in 1 lio winter 1854-85 very fow wore scon; the same in 188,-';6 asin the last three meutioned yours; hares wero extremoly abunelunt in the north; they; probubly found suficiont food to maintain them thero; arrives in Octolser, departs in Feloruary or early in March. (Nash, in MSS.)

Proc. N. M. 90 


$$
\rightarrow
$$



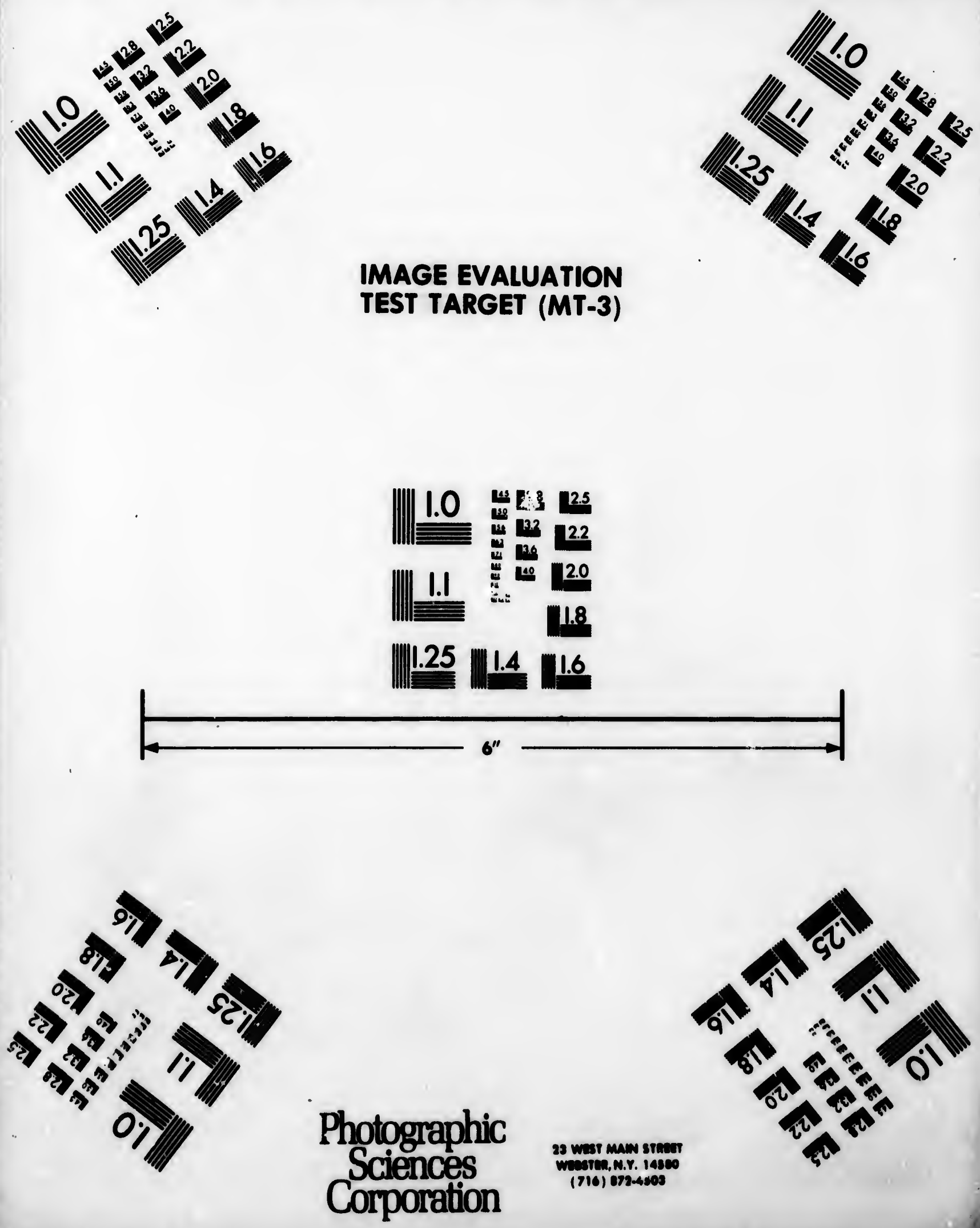
An irregular winter visitant. Winnipeg: Winter visitant; arrives in Septeuber, departs in April ; very abundant in winter of 1884-'85 (11ini?). Red River Valloy: I am positive that it is a permanent resident and breeds in the wooded country enst of the Red River (Hunter). Winter resilent; very common at Riling Monntains fall and winter, 188. ; lot noted at Portage la Prairie (Nash). Carberry : Very abundant in the fall of 1884 ('Thompson). Cnmberland House, May, 1827 (Richardson). Trout Lake Station and Severn House (Murriny).

Un Oetober 18, 1881, while shouting in the half open country to the sonth, I saw a Hawk Owl. Its flight was much like that of a Pigeon Falcon, and it perchen after each change of position on the very top of a tree. I winged it ut the first shot, aud having heard that this speejes use their beak and claws energetically whon wounded, I approached with due caution. It hissed once or twice and endeavored to escape by hopping. After some little handling it attempted to bite, but did not otherwise defend itself. October 28: The Hawk 0 wl seems to thrive very well in continement, and during the past ten days I have haul no occusion to accuse it of any approncli to vicioneness. It hus uften been bandled and if hurt thereby simply expresses its anuoyince oy a chic. kling note, much like that of a Whiskey John. When placed on the ground it progresses rupidly by great hops, but the slightest puft of wind is enough to upset it. It sometimes utters a rolling "whill-illill-ill-1oo," somewhat liko the ories of the Iong. eared Owl. It has never sulked, but from the first has been ready to apply itself to the domoli. tlon of the small birds amd mice with which it has been supplied.

On November 7, while at the poplar bush, I saw severul Hawk Owls ancl secured one alive. This ono is as different as possible in temper from the first I hal. It smaps with its bill and strikes with its clows ut any person or animal that appronches it. It refused all food and con. tinued sulking till it died.

This fall has leeen remarkable for a migration of Huwk Owls. During the antumus of 1882 and 1883 I snw not one about here, but this yenr I have scen above fifty. Its favorite localities appear to be the half-open woods und park lands, and it is usmully seen perched on the top of the bushes and trees. In passing from one tree to another, it ecminonly throws itself heallong down warls nearly to the ground, mong which it skims towards the next treo, mul on nearing its goul rises with in gracelul aibinl bound to the topmost poreh offered.

Somewhat irreguluriy alintributol throngluent the proviuoo. Nonr Portugo Ia Pralria I uever suw it, but in Docouber, 1881, I met with it li grmluslly incroasing numbers from Glablowe to the Rliling Munutalus, whoro it was vory cominon. Thoy are quite diurnal In their babits. Two thot I whot bad nothing in their stomachs. Its fight, partieularly through the low bushes ani sorul, elosely resombles that of the Sharp-shinned Hawk; it akims aloug noisolosely olose to the ground, frequently alighting ou the top of $\mathrm{n}$ bush, from whence it will dast on a unouse or other pray. It alno frequently rises high in the air and hovers over the ground, romaloing sta.

liouary ov Hawk.

On Nove

A tole Pembina jug : Su arrived J resident; the Red Carberry west, ani slope of Shell Riv and breed (Macoun)

On Jul heard tly Riuin Uro ti'y. Thi ach was 1

On Au the after with cute slightly o

On JuI Duck Mi "kow-kou on the pr after a lit 5 foot fro lectly ind cluaracter

These : to $\mathrm{my}$ edr est lifo ar

(On the in the gro

Commo lakes; 0 Peinbina, 30 (Dawa Swacopy 
t; arrives in 4-85 (11ine). esident and rr). Winter er, 188.t; liot ndant in the Richardson).

untry to the ; of u Pigcou a very top of t this species approached to escape by , but did not ims to thrivo have haul no uns uften been see uy a cliuc. olaced on the ghtest jutt of ng " whill-ill. It lias never o the demoliplplied.

Hawk Owls blo in teunjer h its olaws it food and coll.

Dwls. During ut this yeur I the half-open the top of the it commonly long which it ith It graceful

ortago la Prairio manlig numbers unon. Thoy wre - atomoohs. Its bles that of the und, frequently or othor prey. romaluing ato

tionary over one place for some timo, exactly like a kestrel or our own Sparrow IIawk.

On Novomber 26, 18\&6, I saw ono on tho banks of the Red River. (Nash, in MSS.)

132. Coccyzus erythrophthalmus. Black. billed Cnckoo.

A tolerably common summer resident in wogdlands. Breeding in Pembina Mountain (Uoues). Red River Settlement (Brewer). Winni. peg: Summer resident; tolerably common (Hine). Oak Point: 188t, arrived June 1 (Sinall). Portage la Prairie: Tolerably commou summer resident; arrives abont June 1, lleparts in August; not observed on the Red River near Winnipeg; in 1884, first seen May 31 (Nash). Carberry : Tolerably commou summer resident; noted near Shoal Lake, west, aud eastwarl toward Rapid City (Thompson). August 29, south slope of Riding Mountain, American Ouckoo observed (Hind, 185̃8). Shell River; 1885, first seel, two, on Jume 16; is common all summer and breeds here (Calcutt). One shot on Moore Mountain July 3, 1880 (Macouu). Qu'appelle (Guerusey).

On July 29, 1882, at Oirberry, while out in the woods to the east, I hearl the sonorous and to my ear pleasing "kow-kow.kon" of the Rain Orow or Black-billeil Guckoo, the first I have hearl in the coun.

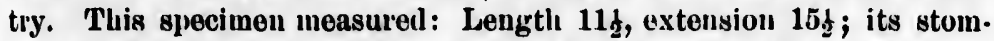
ach was filled with vegetublo matter and the romains of insects.

On August 13, at Carbolry, shot in chckoo (erythrophthalmus) in the afternoon; male; length 11, extension 15; stomach was crammed with caterpillars and grasshoppers; its inner coat seemed to be very slightly covored with minute hairs. Several of the species were seen.

On Juno 23, 1884, near Shoal Lake, returning with A. S. T. from Duck Monntinin, for the first time noted the cuckoo. The sonorous "kow-ko10-kon" eame agnin and again from a little grove of poplurs on the prairie. I went towards it and presently heard it behiud me, and after a little more searching I discovered the birc on a branch sibont 5 foet from the ground and 10 from where I stool ; it was sitting per. fectly motionless, witching mo closely, and deliberately uttering the characteristic koic-kones, varied with other sounds of the same nature.

These notes have often bien deseribed as hart and disagreeable, but to $\mathrm{my}$ eur they are uot unmusical und are full of associatlons with for. est life anc oilors that make them pleasing to my mini.

(On the succecllug duys of June, I fonni this species quite mbundant in the groves ou tho priries botween Shonl Lake, west, nud Curberry.)

\section{Ceryle aloyon. Holtol Kinglisher.}

Common summer resilent along all fish-frequented strenns unl lakes; of general dlstribution; Pembina and Monse River (Ooues). l'einbina, May 1 (Blnkiston). Dufierin : Arrived between April 25 and 30(Daweon). Winnipeg: Snmmer resillent; tolerably common (Hiue). Swampy Islaud: 1835, flrst seou, oue, ou May 18; next sceu Muy 10, 
after which it becume tolerably common; breeds here; in fall was last seen on September 24; 1856, first seen, one, on April 29; bulk arrived May 15 ; last seen May 22 ; is rare here(Plnnkett). Speeimen in Swith. sonian Institution from botween Hudson's Bay and Lake Winnipeg, also from Red River Settlement, Pembini, May 1, (Blakiston). Lako Winnipeg (Bell). Shoal Lake, May 15, 1887 (Christy). Portage la Prairie: Common summer resident abont tho streams and lakes; arrives early in May; commences nesting about the 15th of the inouth; departs in October; in 1884, first seen May 5 (Nash). Very abunlant on Red Deer, Swan, Assiniboine, and all rivers along route of 1881 (Macoun). Carberry: Sumıner resident; more seon in springtıme (Thompson). Dalton: 1889, first seen, one, on April 29; moving unset. tled; rare here and not breeling (Youmens). Shell liver : 1885, first seen, one, on May 1; next seen, nu, on May 3; a transient visitant; not breeding (Ualcutt). Qu'A puelle: Tolerably common summer resident ; breels; arrives May 30 (Guerusey).

I have never seen this species in the vicinity of any of the drainage lakes, although they sbound with amblystoma, insects, etc., to the exclusion, however, of tish.

134. Dryobates villosus leucomelas. Northern Hairy Woolpecker.

Common resident of the woodlands. In heavy timber on Turtle Mountain (Cones). Winnepeg: Rare; breeling (Hine). Portage la P'rairie: 'Tolerably common resilent (Nash). Touch wood Hills and Lake Mani. tobil, and north ward, 1880; in the woods along the led Deer and Swan livers, 1881 (MacollI). Carberry : Oommon; breeding; probably resi. cient, but not observed by ino in the very colilest weather. Rat Port. age: Tolerubly common ('Thompson). Qu'Appelle: Tolerably common; jermanent resident (Guernsey).

On June 11, 1883, while in the spruce bush, I hearl a curious chirp. iug sound that scarcely ever seemen to cense. I trucel it to a tall pop. lar tree, In whose trunk there was a hole about 30 feet from the ground. Having procured an ax I soon had the tree down, and found myself in possession of a nest of young Hairy Woodpeckers. They were in a hole, eviclently the work of the parent biris, about a foot deep, 3 inclies wide inside and 2 at the eutrance. The four youngsters were neurly grown and fleiged, and consequently were much orowded in this narrow chamber. Threo of them wero precisely ':ke the mother-bird in color and the fourth differed only in liaving over ench sar a cockale of rioh yellow. I took them home with me aud found that they hal enormous appetitis, nearly unlimited capneity, und trementous lung power. The whole diny long, when not oating, they kopt up a deafoning chirr-chirr-chirr, and two of them, incluling the yellow.topped one, never cer sed, except in ubsolute darkness. Hven while morsels of fool wore passing down their greedy thronts they wonld continue to gurgle out a miflicteney of interrupted chirr.ohirre to save tho principle. I found that at one menl

each of $t$ not find $i$ lay, and pirients I dicl, and insects, c entailed each corn white tiss had supp the newly periment that the bircls nev oring for moment t

The us also a ha lisingtishe strilululou:

Toler:al pegr: Res (Cliristy). resident Manitoba ably resin

Commo proenred stitution is Octobe IIore num iligrator beer liliv On No tappling where is although sign of $v$ identiffer spruese 1 n sapperd one larvo 
Il was last lk arrived $n$ in Smith. Winuipeg, ou). Lake Portage la lakes; ar. he inouth; abundant te of 1881 springtume ving unset. 1885, tirst isitant; not or resident;

ie drainago , to the ex.

recker.

urtle Moun. la Prnirie: Lake Mani$r$ aud Swau obably resi. Rat Port. ly common;

rious chirp. a tall pop. the gromind. d inyself in 4 were in a ep, 3 inches wore nearly this narrow in color natl rich yellow. 18 appetites, e whole d:iy r.ohirr, suld sorl, ex(tept assing down ifficieney of at one meal each of these birds could take 2 fect of the entrails of a duck. I did not find it convenient to feel them more frequently than three times a day, and each meal-time found them ravenous, so that probably the purents provided them with much more foni in-the aggregate than I dicl, and as all they brought them wonld probably bi maggots and iusects, caught singly, wo may form some idea of the enormous labor entailed by the rearing of a young brood. These young birds have at cach corner of their uouths the usual boss or romdec mass of yellowish white tissne. I have never been able to decide on the use of this. I lad supposed that it is intended to widen tho gape, as it is largest in the newly-hatched bird, but is gradually absorbed as they grow. Ex. periments, however, with these young woodpeckers led me to believe that the nerves of taste, or at least of tonch, are locatel there, for these birls never would open their beaks to receive the fool they were clamoring for at first when I touched them on the beak or breast, but the moment this soft luup was touched they were wide agape.

The usual note of tinis rather noisy birl is a lond chuck, but it has also a harsh, prolonged, rattling cry, somewhat of the uature. of the kingtisher's rattle, but varien and lengtheued with a combination of stridulous sereams.

\section{Dryobates pubescens. Downy Wondpecker.}

Tolerably common in wooded sections; said to be resident. Winnipeg : Resident; abmulint; breeding (Hine). Slıonl Lake, May 15, 1887 (Christy). Ossown(Wagner). Portage la Praire: Tolerably common resident (Nash). Iake Manitoba and westwarl; specimen shot at Manitoba House, Jume 16, 1881 (Macoun). Uarberry: Uncommon; prob. ably resilent (Thom |son).

\section{Picoldes arcticus.' Arotic Three-tood Woodpocker.}

Common resilent in the woods, especially among spruce. Specimens procured uear Red River Settlement by D. Gun in Smithsonian Institution collection (Blakiston). Very abunlant about Rat Portage in Oetober, 1886; also in all the spruce wools near Carberry; it is there unore numerous in winter thun in summer, thorefore it may be partly migratory (Thompson). Specimens shot at the confluence of lien Deer kiver and the Etimoines River (Mneoun).

On November 4, 1884, while out deer-hunting, I was guided by the tapping ancl "churking" of a Throe-toed Woodpecker to the place whers he was busy foraging oll the trunk of a spruce tree, and althongh I scored a elean miss the bird fell dead at my feet without a sign of violeneo abont it. It was a female and the stcinacli contents, as illentified ly, Dr. Brodio, areas follows: Eight larvo of a Buprestis (a sprues borer); flve larvo of mother species of Buprestis, five lurve of a saperda (a pine borer); one lurva of a Lepidopter, probably a moth; one larvin not distinguishable, and a smill quantity of wood. 
137. Picoides americauns. American Threo-toed Woodpecker.

Very rare, but probably general in the north and east. Winnipeg : very rare (Bine). I have taken this bird on the Brokenheal River, also on the Winnipeg (R. H. Hunter). Rat Portage, October 21, 188t, saw what I took for Picoides americanus ('Thompson). This birl exists in all the forests of spruce-fir lying between Lake Superior and the Aretic Sen, and it is the most common woodpecker north of Great Slave Lake (Richardson). Severn House (one specimen), the common Threc-toed Woolpecker (Murray). Hudsou's Bay (Hntehius).

\section{Sphyrapicus varius. Yollow-bellied Supsucker.}

Coinmon summer resulent of wooded section; plentiful at Pembina, where it was breeding in Jume; agrain seen on the Mouse River; not observed further north (Cones). Winnipeg: Summer resident; abul. dant (Hine). Shoal Lake: May 20, 185 T (Christy): Abundant arounl Lake Mauitoba anl westwarl ; specimen shot at Mauitoba House, and Swan Lake Honse, June and July, 1881 (Macouu). Carberry: Com. mou summer resillent; breeling ('Thompson). Shell River: 1885, first seen a pair on May 3; a transieut visitor; not breeding (Csilcutt).

On June 20, 1883, at the spruce bush, I found the nest of a Sap. sucker. It was in a new hole in a green poplar tree, about 30 feet from the gromul. It containerl five newly hatched young, and in the ehamber with them were some of the shells, ont of which I reconstructed two eggs. The male, leigth $8 \frac{1}{k}$, stomich full of ants, the feinale, length 83 , stomach full of ants, her bill also, was full of black ants, intencler probably as fool for the young ones, excessively fit, no red feathers at all except three,or fonr scattered on the front of the crown, which was black. The eggs were each $\frac{13}{18}$ by $\frac{5}{8}$ and pure white.

Oi .July 3, in spruce bush, with M. C. found the nest of a Sap. sucker. It was about 20 feet from the ground in a poplar, and facing the sontheast. Just over the hole was a large limb, which would loubtless be of some service as a shelter from the rail. I shot the female; her crown was black, with but a very fuw rod feathers in the front, and some of these were tippel with yellow. The gizzonrd was full of wood muts (Fornica rufa).

139. Ceophlceus plleatue. Pilentel Woodpecker. Cock of the wooda.

Rare; resident in henvy timber. Winnipeg: Summer resilent; toler. ably common at Lake Wiunipeg and ake of the Wools (Hine). Sel. kirk (GIIII). Bwampy Islanils: Tolerably common resilent; breeds here (Plunkett). Nelson liver (Brewer). Very rure summer resideut; saw one that had been shot in the woods near the IVhito Muld River at Westbonrne in 1887 (Nash). The species was seen on Swan River, Septemlver :', 1881 (Mnomin). Oommon in the wools between Winni. p'in and I (Dr. Arth Prince All

On Octc W. S. Tho In the aft

There is blooming er skins of tl Also descril $50031^{\prime}$ N., Ic lioles of tre Olsservation

14

Rare \$แ Summer $\mathbf{r}$ (Hine).

the town same birc summer re

Red-heade as I conclud this to the fin Bay, 1782.)

141. Co.

Very ab mon alou Turtle Mr 2) (Daws with pale Winnipeg immense Ossowa : April 21; latge la $\mathbf{P r}$ departs pegoses $r$ Reul Dees mer resic first seen April 15; on $\Lambda$ pril brceds he rives $A p r$ as it feed 
m'g and Rat Portage, also about Lake Winnipeg in the spruce woods (Dr. Arthur S. Thompson). Mr. Hine showed me a specimen taken at Prince Albert; two seen at Rat Portage (Thompson).

On October 16, at Rat Portage, a Pileated Woolpecker was shot by W. S. Thompson; male; length $18 \frac{1}{2}$, extent 29 ; stomach full of ants. In the afternoon saw another in an elevatel piece of burnt wools.

There is another species of Woolpeckers, the size of a migratory pigeon, with a hlooming crimson crown. They inhabit the interior part of Hudson's Bay. The sking of their licad aro uscel by the trading natives to ornament their calimats. Alsn describes a specimen. It was shot in Jannury at Gloncester House in latitnde $50^{\circ} 31^{\prime}$ N., longitude $96^{\circ} 3^{\prime}$ W., and 387 miles np Albany River. Makes a nest in the inoles of trees; lays six eggs and brings forth its young in June. (Hntehins MSS. Observation on Hulson Bay, 17x2.)

\section{Melanerpes erythrocephalus. Red-ìcaleil Woodpecker.}

Rare summer resident; conınon at Pembina (Cones). Winnipeg : Summer resicient; tolerably common ; one or two pair seell each season. (Hine). Very rare snmmer visitor; May 31, 1885, saw one bird near the town (Portage la Prairie) ant a day or two afterwards saw the same bird or another near the same spot (Nash). Carberry: Rare; summer resident (Thompson).

Red-headed Woolpeckor. * * This bird is uncommon in theso parts (Albany), as I conclucle from the ignorance of the natives in general concerning it. Perhups this is the farthest parc of its migration. (Hutchins MSS., Obsorvations on Hulson Bay, 178\%.)

141. Colaptes auratus. Flickor. Highllolder. Golden-winged Woolpecker.

Very abundant; summer resident wherever there is timber; com. mon along Red anil Monse Rivers; also observed at Pembina mul 'Inrtle Mountains (Cones). Dufierin: Arrived between April 15 and 20 (Dawron). In " Selkirk Settlement specimen the belly is tinged with pale sulphur yellow, tho back with olivaceons green (Ridgway). Winnipeg: Snmmer resident; abundant (Hine). Nelson River: In immense numbers at Rell River Settlement, April 26, 1859 (Blakiston). Ossown: Breeding (Wagner). Oak Point: 188ð, first seen, one, on April 21 ; next seen on 22,l; is common and breeds here (Sinall). Por. tage la Prairie: Abunlant; summer resident; arrives abont April 20; lleparts early in Octoleer (Nish). Common thronghont the Winnepegoses region und along the Assiniboine wherevir there were trees; liel Deer Iake, Angust 20 (Mucoun). Oarbery : Abundant; summer resident; breeling; Lat Portage ('Thompson). Dalton: 1889, first seen, one, on $A$ pril 12; next seen, $A$ pril 13; became common on April 15; breels here (Yonmuns). Shell lRiver : 1885, first scen, two, on $A$ pril 27; afterwards seen every day; is eommon all summer, and breeds hore (Oalentt). Qu'A ppelle: Gommon; summer resilent; ar. rives April 25 (Guornsey). 'Trout Imke: One of the woolpeckers, bnt, as it feeds on ants unl therefore does not require so much lulor to get

lent ; toler. (ine). Sel. it; breeds r resident; Incld IRiver wan River, een Winni. 
its fool as tho other wo: lpeckers, its bily is less euiterl for such work; it is only i summer visitant to the fur countries (Murray).

On May 31, 1883, found a Flicker's nest in oak stub, only 8 feet high; the hole was 18 inches deep, but the wood was quite rotten, and I hal no diffienlty in reaching the eggs.

October 27, 1882, while examining an old stnmp in the woods to the nortl of Carberry, I met with an excellent illustration of the aptitude of the Spiuish name for the woolpecker, "Il Carpentero," as applied to our Flicker. I mean in the sense of its being a worker in wood and honsa provider for others. The history of the case was briefly this, as far as the cirenmstantial evidence revealed it: First came the hardworking Flicker and exeavated the hole, perhaps while yot the stump was somnd, and in the years that followed we know not low many young Fliekers eracked their glass-like shells in this narrow chamber: and after the Flickers came no more it was taken by some bird, a grakle perhaps, that, like the "foolish man," founded its nest on mud, finish. ing its superstructure with sticks and straw. Then, it seems, came a new possessor, who built a strong, shapely nest of moss and mud; but for the situation it uright have been the work of a robin. Lastly, this many-storied tenement house became the eyrie of a sparrowhawk, whose household furuiture of straw and moss reached halfway up to the door. way. A strange tale of $n$ hole, surely; but there was more yet to be learned from the old stul, and, allowing fullest weight to circumstan. tial evidence and accepting the supposititious as a fact, 1 may be al. lowerl to relate as a matter of established history that on a certain day Sir Faleo sparverius brought home to his brood a tiny shrew, of the species yclept by scientists the Sorcix cooperi. Now, it chanced that the young hopefuls of the robber baron were not just then very hungry-oh $1 \mathrm{mar}$. velous chanee-so that the Sorcx cooperi, being left to his own devices, set about to escape, and so far succeeded that he birrowed down through the home effects of the Kestrel and the moss-builder, but when so far the harl mul floor barred further progress, and the poor little captive, weary and wounded, soon died in the buried nest; and there I found him, like Ginevra in tho oaken ehest, when long afterwards I broke open the rotten timber and made it diselose a tragic tale that, may be, nover happened at all.

In this region (Carberry) the flieker seems to prey principally on ants, taking them sometimes from the rotten stumps that aro honeycombel with their galleries, but more often, I believe, from the monnd-like antlills which are to be seen on the prairie in snch numbers. His methol of attaek seems to be by first pecking a hole in the center of the hill, and theu as the ants come swarming ont he clispatches them till his ap. petite is satisfiel. Afterwnrds he comes again and again to the hill till it is completely depopnlated.

On the 27th. July, 1884, I naw one of these birds dnsting on a sandy spot near the Asainiboine River. IFo jereformod tho oporntion as skillfully as a quail and was ovidently used to it. 
heh work;

feet high; and I had

oris to the uptitude of applied to wood and fig this, as the hard. the stump any joung mber: and , a grakle hudi, finish. as, came a mud; but tastly, this awk, whose 0 the dooryet to be ircumstanmay be al. ain day Sir the species the young -oh! mar. on devices, iwed down r, but when poor little and there terwards I o that, may

lly on ants, nejcombed d-like antGis methol of the hill, till his apthe hill till

unot near the and was evi-
In cold, stormy weather they roost on the ground amongst the long grass at the root of a stump or tree. On tho 29 th September I put several out of such places just at dark. They wero very loth to leave, my dog almost jumping on them before they would get out. (Nash, in MSS.)

\section{Antrostomus vociferus. Whip-pon-will.}

Coinmon summer resident in woods and bluft's. In numbers at Pembina (Cones). Pembina (Lay). Dufferin : Arrived May 8, 1874(Dawson). Winuipeg: Summer resident; abuudant (Hine). Its voice is known at Red River Settlement (Blakiston). Ossowa: Breeding (Wagner). Uak Point : 1884 ; first leard May 8 ; next heard May 12; heard again on 13; is common and breeds here (Small). Portage la Prairie: Common summer resident; arrives abont May 20; departs early in Septeinber; found young partially fledged as late as July 29 (Nash). Aloudant in the north ; Manitoba House, June 17, 1881;. Grand Valley (Macouiu). Carberry: Common summer resident; breeding; Long River (Thompson). Two Rivers : 1885, first lieard, one, May 21; next, May 24; fuirly rare (Criddle). Brandon : May 25, 1887 (Wood). Shell River : 1885, first lieard, one, May 20 ; common all summer; remains until August (Calcutt). Qu'Appelle: Occasional (Guernsey).

On May 17, 1882, at Long River Gorge, a partly wooded country, the best we liave seen ret, heard a number of whip-poor-wills chanting their familiar strain towarls night. This is the first notice of their arrival. June 6, went late in the evening to the eastern slough to observe the two nightjars. Both of these, as well as the mosquitoes, were in full force. But as the slutes of night closed in the night-hawks that hitherto had been chiefly noticeable became less noisy, and their cousins, the whip-poor.wills, became the principal performers in the full concert. How many there were it would be hard to siy, but certainly not less than a dozen appeared to be in the near neighborhood, and the chorus of voices loudly reiterating "whip-poor will" was always a full one of at least three voices. As I lay in the grass and listened to these various voices of the night I attempted a elumsy imitation of the notes "whippoor-will," and was pleased to see one of these hirds come flying around me closer and closer until at length it hovered but 18 inches from my face in the grass. For a moment or two lie poired and inspected me; then flying away he returned immediately with another, his mate probably, and the pair skimmed about me once or twice; then the wing inotion, which I could burely discern in the gloom, ceased in the vicinity of a certain stump close at hand. At once I concluded that the bird had alightel, and then the calmness of the night was shocked by the usual tringerly.

The refrain is almost too well known to need lescription. It consists of three, or sometimes four, notes, "whip-poor-wlll," or "ah-whip-poorwill." The "ah" is very finint at best; the "whip" anl "poor" are rich and smooth, but with an accent on the former: the "will," nttered 
with a lattle, great foree, ancl empluasis, seems at half the distance from you and not quite the same direction as the first notes.

On June 27,1883 , in the iry open woods to the south, I found the nest of the whip.poor.will. The two young ones were covered with yellow clown, which mate them very conspienous on the dark lenves. They were close to the baso of a very large poplar and only 20 feet from an oven birl's nest. No attcinpt at nest building was observable.

'The whip-poor-will (Antrostomus vociferus) difters from its neur relative, the night. hawk, in soveral particulars. It seldom leaves the woods and comes out onto the open prairio; aud even among the trees it is sellom or never seen sailing ahont high overhead during dnylight. It is nlso a much shyer bird; and, althongh its highly remarkable far-sounding voice may often be hearl, it needs great caution to get willin s sufficiently short dlistance to see the porformer. (Christy.)

143. Chordelles virginianus sennetti. Night-laswk.

Very abundant summer resilent. The type of this variets was taken by the describer, Dr. Cones, on the boundary 50 miles west of Pembina. I therefore assune this to be our only form. Pembina and westward along the bounclary to the Rockies (Cones). Winnipeg: Summer resilent; abundant (Hine). Ossowa: Breeding (Waguer). Oak Point: 1884, arrivel May 25; 1885, first seen, one, on May 19 ; next seeu on May 23; is common and breeds here (Small). Portage la Prairie: Abundant summer resilent; arrives a bout May 20, leparts about September 15; in 1884, first seen May 27 (Nash). Alundant in the Northwest; specimen shot at Manitoba House, June 16, 1881 (Macoun). Carberry : Abundant summer resilent ; breeding (Thomyson). Dalton : First seen, one, on May 27 (Youmans). 'Two Rivers: 1855, first seen, several, May 23; next seen, May 25; beeame common on anil after May 27; breels here (Cridllle). Shell River: 1885, first seen, one, on May 23; next seen, ten, on May 24; is common all summer and breels here (Calentt). Qu'Appelle: Oommon summer resident; breeds; arrives May 21 (Guern. sey).

On Angust 1, 1883, while in the eastern sand hills with Miller Ohristy, we foaml the two young of a Night-hawk sitting on the bare ground in the open. They seemerl about 3 ilays old. On the tips of their beaks were still the hard white points with which they nre furmished to aid them in chipping the shell. The old shells were lying around the nest, as is the case with the Precoces, ancl but for these I should have passed by the young ones, as they hal squatted elose to the ground and slunt their eyes, for the blackness and brilliney of these woild almosi certuinly have betrayed them. I gently touched one of them, whereupon it crouched down more elosely to the ground ; but its companion, rising up, hisserl with open beak and snapped savagely at my fingers. On being further teused they rau off, exactly in the mauner of young ducks, with ontstretehel wings and with neek and borly at an angle of 45 degrees. After running a fow fect they stopped, squatted as before, 
nce from

bund the with yel. s. They from all 8. the night. t onto the hlont high its highly tion to get.

as taken Pembina. restward mer resiint: 1884, I on May bundant mber 15; st; specilarberry : irst seen, ral, May ; breeds 23 ; next (alentt). 1 (Guern.

Cluristy, o ground eir beaks ad to aid the nest, o passed and shut nosi cerlereupon III, rising exs. On g ducks, le of 45 before, and elosed their eyes. This ther peated several times, lut at best they ouly made little progress, and each time on being overtaken the bold one was always ready to fight. This proved to be a male; the sex of the other was not ascertained, but probably it was a female. At this age the middle elaw is not pectinated.

In the light of these observations it seems likely that in snme of the cases in which the Night-hawks are supposed to have carriet off their young, the latter had really run from danger, or were led away by the parent birds. It is pretty well established that these will remove their eggs from a dangerous locality, carrying them in their mouth, but it is difficult to understand how they conld so transport their young.

On Mas 29, 1884, watehed a Night-lawk bonming a number of times in broad daylight; each time, just as the boom hegan, the wings were hrought forward, so that the two together formed a half moon, with the points downwards, and as well as I could discern, the tips of the wings vibrated out of sight while the somil continued.

The courting and mating coremonies, apart from the booming, are carried ont chiefly on the ground, where the male may be seen chasing his mate about and aronnd the logs and bushes. When thns engaged they do not hop, bnc always run, as far as I have been able to observe.

As already intimated, the eggs, which, to the best of my knowledge, never exceed two in number, are laid on the $i$ re ground; they are peculiar in being of the same shape at each end, both in fact being big ends. When sitting on them the old bird will elose her lustrons black eyes and remain perfectly still intil nearly trodien on; then, finding herself discovered, she will flutter off and attempt, by the nsual shamming of laneness, to lear the intruder away from her treas. ure. According to Aulubon, these birls will removo their eggs when much molested. My own experience shows that they will desert the eggs, but I have never known them to be removed by the hirds them. selves.

The old theory of the Night-hawk's booming was that the sound was caused by the air rushing past the wide, gaping throat; but tho present idea seems to be that it is name by the wings. In support of the latter I would adiluce the following reasons: First, the sonnd bears erident resemblance to the drumming of the partridge and of the snipe; second, it may be accurately imitated by throwing a large nail sideways through the air; and last, the following observation on the crow, a not very wide-monthed bird, points, I think, to a wrong origin for the sound.

Toronto, May 14, 1885: While watching a crow being chased by another, I noticel the foremost one dive suddenly downwards and then up again; the pursuing bird followed even more quickly, and as it swooped upwards it producel at the turu a boom similar to that of the Night-hawk, but duller and in a lower key, us might have been expected from the larger feathers aud slower flight of the crow. 
The Night-hawk subsists chiefly on insects, which it revours on the wing; but Wilson examined some whose gizzards wore fnll of crickets, a prey that must bave been taken froin the grouml. On several occasions I bave fonnd the stomach full of grasshoppers, and in one I found a number of pebbles. As soon as the young ure stroug on the wing the specios is seen in llonks and begins to lepart, for it is oule of the enrliest to move of the fall migrnnts. These flocks are very long and straggling, thongls few in numbers; the largest I ever noted contained forty-one of the birls. (Carberry.)

The eggs of the Night-lıawk (Chordeiles virginianus) weresoveral timos founcl on the bare ground auroug the sand hilly [on the north slde of the Souris, near Plum Creok], with no approach to a nest for the halpless young. The parent birds endeavored to draw us away from their eggs, finttered as if wounded a short distanco from thom, and nttering cries of distress. (Hivd, $\mathrm{J}_{11} \mathrm{~F} 1,1858$. )

Among the trees on the sand hills and in the bluffs the Night-hawk (Chordeiles popetue) is abunlant and makes itself very conspicnons towards evening by its lond scream, by boouing, and by displaying during flight the nunistakable white patch on each wing. Not unfrequently it muy be seen on the wing at millay; and it always makes an appearnuce long before sunset, sailug ulont nt a great lieight aul screaining frequently. After flying $n$ while over the head of any intrucler it suldenly oprends jts wings, and, giving a wide swoop downwarls, emits a lond booning noise, which has gained for it in some parts of Ameriea the name of "Bull Bat." That this noise is made over one's heal in order to threaten or intimidnto seems to me pretty certain; but I have also, I believe, heard it emitted at $n$ distance, withont any euch object.

The number of old birds began to get very much less by the end of Augnst, but a fow were nevertheless seen until well on into September-one as late as the 11 th. After the migration commenced they werv not un[rejuently seen in the eveninga flyiug over in large straggliug parties, circling ubont as they proceeded. These partius usually traveled sontluwest, I believe, thongh this is not the direction usualiy chosen by the other birds of the district when moving senth. (Christy.)

Early in Jnne, 1832, I witnessed the courtship of a pair of these birds. It was a very pretty sight. The spot seleeted for their meeting was $n$ smull bare patel of grouud in the edge of the scrub, evidently where an old camp lire had been made. Abont this the male strutterl, posturing ntost gracefully bofore lis mistress, reminding one somewhat of the anties of a male tamo pigeon when similarly engagel. (Nash, in MSS.)

\section{Chæotura pelagica. Chimney Swift.}

Tolerably common summer resiclent. Common at Pembina, and thence westward to Mouse River (Coues). Pembiua (Lay). Winnipeg: Summer resident; nbundant (Hine). Portage la Prairie: Com. mon summer resident; arrives about May 16, departs early in Sep). tember; in 1884 first seeu, May 17 (Nash). A fow observel at Swan Lake Honse, July 8, 1881 (Maconu). . Carberry : Rare and not breeding (Thompson). Brandon: April 21, 1887 (Woot).

$\Lambda$ nest oxamined by me at Winuipeg, July 15,1883 , containel four ogge. The young were hntchel a fow days after. From that tims the young remaineil in and aronul their nest until Septembor 4 , whon they flew for the first time, ar a at once disnppeared. After the young grew too large fir the nest they arranged themselves In a row, tonching one nusther, bnt slightly below oach other, nind clung to the wall. In that position they remained until they took their thal departure. (Nasb, in MSS.) 
wing; but must have ach full of young ure it is olle of traggling, tho bircls.

und on the um Creek], leavored to from them,

(Chordeiles by its loud te patch oul ll it alway, nel screain. t suldenly d booming Bull Bat." to seoms io ce, withont

t, but a fow After the ing over in ies usually osen by the

3. It was a re patob of been made. \$8s, remind. y engageil.

ina, and Winniie: Com. in Sep. at Swan breeding

eggs. The nell in and ca at once theinselves $n$ the wall. $h$, in MSS.)
145. Troohilus colubris. Linby-throated IInmming Birl.

'́olerably common summer resident of sleltered gardeus. Quite common at Pembina; not seon west of this point (Uones). Dufferin: Arrived Muy 17, 1874 (Dawson). Known about the gurdens of Red River Settlement(Blakiston). Winnipeg: Summer resident; tolerably common as far north as Big Island Lake, Manitol ; (Hine). (Jak Point: 1884; arrived May 25 (Small). Portage la Prairie: Common summer resident; arrives about June 3; also noar Winuipeg (Nash). Specimens seen on Red Deer River, at tho head of Lake Winnepegosis, Angust 16, 1881 (Macoun). Not observed on the Big Plain (Thompson), August 29, south slope of liding Mountain, humming birds wero observed; Bad Woods; "First humming birl was noticed here" (Hind, 1858). Shell River: 1885; first seen June 3 (Calcutt). Qu'Appellu: Oecasional; not plentiful (Guerusey). Norquay: 1884 (Cluristy).

146. Milvulus forficatus. Soissor-tailed Fycatcher.

Accidental visitant. Winnipeg: Accidental (Hine). Portage la Prairie: One found by Mr. O. W. Nash, 2 ll October, 1884.

The Swallow-tailen Flyenteher (Milvulus forficatus) is such a characteristically southern bird that its accidental occurrence in Nanitoba is worthy of note. Last Jauunry I was shown in splendid specimen taken at Portage la Prairie ly Mr. Nash. He found it lying dead on the prairie ou the 20 th Oetober of 1884 . Its stomach was empty, and the bird was very emaeiated, although in fine plumage. On the previous uight there was a sharp frost. In addition to this recorl, I quote the following rather startling statement from the Report on the Hudson Bay, by Professor Bell, of the Canadian Geological Survey, 1882 :

But the most singular discovery in regard to geographieal elistribution is the finding of the Soissors-tail, or Swallow-tail, Flyeatchor (Milvulus forficatus Sw.) ut York Factory. - * The specimon in the Goverument Museuu was shot at York Factory in the summor of 1880 , and I have lesrued since thut these reuarkable birds were occusionally seen at the posts of the Hudson's Bay Company, all the way west to the valloy of the Mackenzie River.-E. E. 'T.

147. Tyrannus tyrannus. Kingbird.

Very abundant summer resident wherever there are any trees; extremely numerous at Pembina; breetling; abu laut along the line westward to the Rockies (Coues). Winnipeg: Summer resident; abundant (Hine). Big Ridge: Most common of all was the tyrant flycatcher (Muscicapa tyrannus) which endeavored to hold unclisputed sway over the bluff' he had selected as his home (Hind). Ossowa: Breeling (Wagner). Oak Point: 1884, arrived June 3; 1885, first seen, one, on May 21; next seen, one, on May 22; is common and breeds here (Small). Portage la Prairie: Very common; summer resident; arrives about May 17; departs the first week in September; in 1884, first seen, May 17 (Nash). Very common throughout the Winuepegosis region examined in 1881 ; 
chiefly on borders of prairies or openings (Maconin). Carberry : Abua. daut summer resillent; breeling; Duek Mountain (Thoupsou). Two Rivers: 18\$5, first seen, one, on May 21 ; next seen, May 23, when it became common; is common here (Cridulle). Dalton : 1889, first seen, one, on May 24; next seen on May 25; breels here (Youmans). Shell River: 1885, first seen, onc, on May 21; next seen, flvo, on May 24; is common all summer and breerls hero (Ualentt). Qu'Appelle: Oommon summer resideut; breeds; arrives May 24 (Guerusey).

On Jume 21, 188:, lown by the slough in a low bush, found a King. bird's nest. It wis just completed and eontinined no egge yet. The king anl his wife made more fuss over my intrusion thin most birls would have dono liad the nest been full of young ones.

Further on I found another nest of this species. It was placed on the top of $n$ stub, aboit $s$ feet high. The bird flew off. T'lo nest was made of roots ant fine tibors, and contained four eggrs. One of them measured $1 \frac{1}{8}$ by 8 ; it was cremy :vhite, with a fow char spots of brown and lav. ender, inclined to form in wreatl about the large end; the otliers were similar; all were quite fiesl.

On August 20, 15s3, slot al young Kingbird; male; 6.8 14; stomicli fiul of insects; mo crown piatch of bright color. The spe. cies may now bo seen liar ont on the open prairie, a mile or two from timber, catching insects on tho wing or on the gromml, avaling itself of the tallest weeds as perches, or ficiling these it settles on tho prairie. 1 helieve it never runs when on the gromml, but takes wing eneh time it chunges its location. It is common to see the species in small parties of four or flve; these are clonbtless the fimily of the season. They continue together muler the guiclince of the old ones till they migrate. This took place last yeur abont tho first week in September.

On Jume 17, 1884, at Duck Monntains, henrd the blackbirds screaming in the clistance, while ubove their noise was henrd the shrill twitter of the lingbirl. These grickiles hiul ventured too nenr the king's home and he wus showing them their mistake.

July 24, whilo elimbing to a hitwk's nest, tho old birils esume flying about my heal nttering their piereing whistles; these attricted the attention and roused the indignntion of a Kingbirl, who immediately gave chase und soon haul the satisfiction of knowing that he whs making him. self cousummately olonoxious to the huwks, for they could not keep) him off und they would not fly "way, so thint ho worked his tyrunnteal littie will on them much as lio plesuseil. As well an I conld make ont he took serernl rides of over " himiled yiurls on one of the hawks, anil no imbt when perehed on its bick ho was not ielle.

It has been qiuestioned whether tho Kingbird renlly exerts physionl violence with benk, ete., in the nirial combuts for which it is noted, the cor:iter proprosition being that the prednceons birds have a dislike of a scene and know that mu upromr is fatal to their desigus, anil theroforo they beat a retreat as soou ns their vituperutive littlo adversary aupears. 
cry : Abun. son). Two 23, when it first seen, ins). Shell May 24; is : Oommon nd a King. yot. The most birus

aced on the $t$ was made II meisurell vin and lav. ptliers were

$8 \frac{1}{2}$; extent, The spe. ir two from ailing itself tho prairie. ; each timo uall parties son. They oy migrate.

yls seream. rill twitter ing's home

sune tyying terl the atintely gave aking him. I not keep) tyrumuteal imke out he inwks, anil

physical noted, the lislike of $\|$ therefure y appears.
I am inclined to think that while there is mueh truth in the latter view the former is not wrong, as the above goes to show, and the aibrial activ. ity of the flycatcher saves him from any attempt the hawks may wake to summarily ond the persecntion.

The Kingbird has a peculiar method of expressing his devotion to lis mate. On the warm spring erenings he may bo seen leaving his post by her side, in some low tree, and launching ont he rises to a height of 30 or 40 feet in the nir and gives vent to at tremendons sus. tained volley of screams and twitters, luring which ho continues to lart baekward and forward in a frantic sort of a way, making a very '? omonstrative but harmless charge at any passing bird, and illustrating several fancifnl methools of flight until, having relieved his feelings and covered himself with glory, he swoops down into the bush to re. ceive the applanse of the only spectator he seeks to pleuse. The food of this bird consists chiefly of coleopterons insects, but I lave occasionally fouml seels in its gizzard. In tho pursuit of its ordınary prey it may often be seen fir out in the prairic, miles from my trees. Under these cireumstances it avails itself of the tall weels as perches, or, failing these, settles on the ground. 'Tho young eontinne with the parents until all move southwarl.

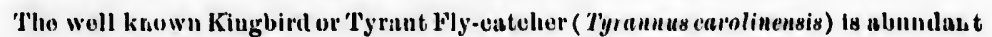
in Manitoba. A more fearless, inyuisitive, pugnaclons, mul warlike bircl it is ditticult to immgino. Oiton when I have shot a birl as it spocimen, up has flown n Kingbirl with a munnel which gave him tho nppenrance of saying. "Now, what's going on

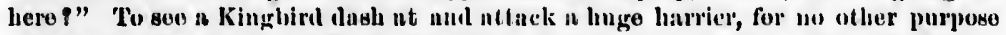
whatsoever than to linve a flylit, is a thing of common ocenirence, nud tho harrior alwiys tries to avoil and escupe from his nssiliant. Tho Kingbiril breels in the low scrubby oak trees which cover tho sind hills, building, like the slırike, a nest consisting largoly of tho stalks of in species of (incphalium. Afler the young are able to fly thoy often live ronnd tho setllors' honses on the open pririo, luit about the ond of Angust they nll lonve. (Christy.)

During Angust I fropuently sic these birils alrop onto the surface of the water of the Red Jiver und remain thore floating down with tho eurront for aome minutes nt in time. Ocensionally they would, whilst there, work their wings as other birds do when buthing, mul so wusli themselves. (Nash, in MSS.)

\section{Mylarchus crinitus. Crestidl lilyentclior.}

Very ruro; summer resident of thick wouls. Wimnipeg: Simmmer resilent; tolernbly common; a few taken (Hlue). Lake Nunitobu: June 17, 1881 (Muenuin). I frequently hemil the sonorous cronk of this bird in the Carberry spruce bush, but nover sutislictorily estublished its presence there until the summer of 1886, when my brither, Dr. Arthur S. Thomp. soil, sent me a mule speeimen, killed there on June 6 ('I'hompson). Portuge la Prairie: Rure summer resillent; one pnir bred in tho woods near the Assiniboine River ench year (Nush). 
Rare summer resilent; one or two pairs seen ench sonson; usually nests under brilges. Winnipeg: Summer resillent (Hine). Oak Point: 1884, arrivel May 15; scurce; 1855, fist Ee(u, two, on May 22; next seen, one, on May 24; is common and breeds liere (Smali). Qu'Appelle: Tolerably coumon; summer resilent; arrives May 20 (Guernsey). Portage la Prairie: On the 11th of May, 185i, I believe I heard one of these birds enlling on the south side of the Assiniboine River, hnt as I was on the north side and the river was bank full I conld not eross to make sure of him (Nash).

\section{Contopus borealis. Olive-sided Flycutcher.}

Common; summer resident of woollands. Winnipeg: Șummer resident; tolorably common (Hine). Rare; three specimens seon on Red Deer River ancl Pembina Mountains; also Waterhen River; evislently breeding (Macoun). Carberry: Tolernbly ('o..umon; summer resident; Duck Mountain, common; Portage la Prairie, oceurs (Thompson).

On July 26, 1883, in the tamarac swamp beyond the spruce bush I uoticed a very noisy iycatcher; its note was loml, and its habits wore much like those of the Great Crested Flycatcher. After some trouble, for it was very shy and kept chiefly among the topmost brmches of certain dead trees, I suecected in getting it. It proved to bo n malo Olive-sided Flycatcher; length, 7 ; stomalı full of flies..

June 12, 1884, Duck Mountain : $\Lambda$ bigh wint has silenced most of the birds. Shot an Olive silled Flycatcher, a male, stomach fiul of beetles and flies; it was uttoring a robin-like "chuck.chuck." The habits of this species scem to be somewhat between those of the Great Crested Fly. catcher and the Wood Pewee. It is quite common here.

\section{Contopus virens. Woorl Pewoe.}

Tolerạbly common; summer resident of woods; Pembinn (Cones). Winnipeg: Bummer resident; tolerably common (Hine). Portuge la Prinirie: Common summer resident (Nash). Waterhen River (Maconn). Curberry: Rare; Duek Monntain, very counmon (Thompsou). A speeimen from nortleru Minnesota in collection of Smithsonlan Institution (Blakiston).

On June 14, 1884, at Duck Monntain, in the spruce woods, I shot a Wood Powee. It was uttering its finmillar druwling note; $p \cdot e \cdot e$ r.e.e, in its usunl sleepy fiushion. It is one of the very eommon birds of the thick woods of this region. Its cousin, the Western Wood Pewee, Is equally common in the moro open woods min groves. I was unable to keep specimens.

152. Contopus rtchardmonil. Westerı Wood l'ewee. Riolinurlson's Pewor.

Tolerably common; summer resident of woonls null blulfis. Winnipeg: Summer resideut; tolerably common (Hiwe). Oarberry : Rare; west 
usou; usually - Oak loint: 22; next seew, Qn'Appello: rusey). Port1 onc of these ht as I was ou ;ross to make

Șumuer resiseell on Red or; evidently ner resident; ompsoul).

ruce bush I s labits were some trouble, brinchies of to bo a male

al most of the all of beetles uabits of this Cresterl Fly.

iiin (Oones). Portage la or (Mucouiı). 1). A speci. Institution

Is, I shot a D.e.e r.e.e, in of tho thick o, is equally blo to keep

I's Power.

Winnipeg : Rare; west

slope of Duck Mountain, common (Thompson). Cumberland House: Juue, 1827 (Richardson).

On June 12, 1884, at Duck Mountain, I shot a Richardson's Pewee. The species seems quite common. In manners, habits, und note, it is a much sprightlier bird than its consin virens. Instead of the drawling p.e e r.e.e of the eastern bird, the usual note of this one is a loud, em. phatic "right-here," which sounds peculiarly appropriate, when, gun in liand, one is cautiously and laboriously following the playful bird through the dense willows it frequents, and inwardly and intensely asking oneself: Where in the name of goodness has he got to now?

This species commonly frequents the open woods and willow thickets, while the virens seems to keep to the higher, heavier timber.

153. Empidonax flaviventris. Yellow-bellied Flycatcher.

Summer resident in woodlands. Duck Mountain, June 11, 1884, shot a flycatcher that was uttering continually a note like "che.blic;" it was all over of a greenish color, but yellow on the belly; it answers fairly well to the description of flaviventris, but is very like an Acadian shot yesterday; evidently the species is breeding here (Thompson).

1.54. Impidonax acadious. Acadian Flycatcher.

Summer resident in woodlands. Breeding commonly at Manitoba House, June 15, 1881 ; nest taken somewhat like a Vireo's (Macoun). Biuscarth : Duck Monntain ; common (Thompson).

June 10, 1884, Duck Mountain: Collected Acadiau Flycatcher to-day; it seems quite common here. June 12, Duck Mountain: Collected another Acadian Flycatcher; the species is quite common here.

155. Empidonas pusillus trailli. Traill's Flycatcher.

Summer resident, and doutitless much more widely diffused and common than these fragmentary observations would scem to indicate; commou at Pembina during the migration in the first week of June (Ooues). Lake Manitoba: June 17, 1881 ; only one specimen procured (Maconn).

\section{Jmpidonar minimus. Least Flyoatoher.}

Very abundant summer resident of open groves; very abundant at Pembina; found also in Turtlo Mountain; breeding (Coues). Lake Manitoba: nesting (McTavish). Shoal Lake: May 15 and 23, 1887 (Ohristy). Oak Point: 1884, arrived May 11; 1885, flrst seen, one, on May 22; is common, and breeds here (Small). Portage la Prairie: Commou summer resident; arrives about May 16 (Nash). Found at Lake Munitoba and Red Deer River; also very cummon in the woods at Manitoba Honse; June 14, 1881 (Macoun). Oarberry : Alsundant summer resident; Turtle Mountain (Thompson).

On May 22, 1882, at land ofilco, Turtle Mountain, saw Least Fly. Proc. N. M. 80-36 
catcher in scrub along the river. It was flitting amoug the brushwood and the branches of the new-leafing poplar trees, uttering a note which I found I could as well-or as ill-express by the totally different syllables "p-chr," "p-chr," or "sé-wick," or " s plit," "s.plit," or " chebec," "chibec," or "s.lick!" Each of these is supposed to represent the same note, and each comes as near it as such descriptions can. This flycatcher was extremely busy jerforce to keep himself alive in this inclement weather, when insects, his only fare, are 80 scarce.

By June 20, the Least Flycatcher is very common in the trees along the slough side woods aud on the edges of every grove. Its constant occupation while perching is to reiterate its peculiar note "chebec." What the "naturally selective" object achieved by this may be, I can not say, unless it has the effect of notifying the various birds of this species of each other's presence, and thereby facilitating and expediting the dnties of finding and choosing a mate.

Un Jnne 8, 1883, shot a pair of Least Flycatchers. One measures :

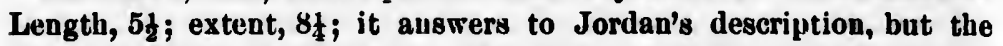
lower mandible is sellowish. The other is similar; it is to be seen darting about after insects in erery thicket and grove; its usual habit is to sit on a prominent lookout twig, punping its tail, and "chebec". fng until some hapless insect passes near, when he censes his too mo. notonous tricks, launches forth, seizes his prey with an audible snap of his mandibles, and dashes again to hie perch to take up the "chebec". ing where he left off. This is a very abuudant species here, on the plain. It is also a very lively bird, and has severul different notes; one of these almost alproaches a soug.

May 30, 1884: Who ever would credit the chebec, a flycatcher, a clamatore, with singing a soug-yet to.day I saw oue that, iu the ex. uberance of his spring exhilaratiou, soared up in the air and hovered in true flycatcher style to vociferate for over half a minute a song like "ohebec-tooral-ooral, chebec-tooral.ooral," etc., und having tuished gave a loud anap with his bill-a smack of delight-und glancell downwarls amlant into a bush.

157. Otooorto alpoetrda pratioola. Prairie Horned Lark, or Prairio Shore Lark.

Abuudant resident of the prairies except in wiuter. Breeding speci. mens from Oarberry and Pembina are identited by Mr. Dwight as praticola, also fall specimen from Rat Portage; from Red Kiver rest. ward, along the bonndary to the Rockies, it breeda in profusion (Uoues)." Shore Lark arrived before April 15 (Dawson). Winnipeg: Bummer reaident; abundant (Hlue). Uak Point: 1885, first seen, four, on March 28; next seen ou 29th; is common, and breels here (Small). Portage la Prairie: 1884; ccmmon spriug and fall visitant; atsys nearly all the winter; disappears and reajpears at intervals; arrivas about Maroh 20; reappears in August, and departs in Octolver (Nash). Very abundant

- Specimeno from the plains proper are 0. a. arenioola.-R. R. 
prushwood ng a note y different " or "che. resent the can. This ve in this

rees along s constant "chebec." be, I can rds of this expediting

measures : a, but the to be seen naual habit "chebec". ais too mo. dible snap o "chebec". ere, on the ent notes;

jeatcher, a , in the ex. d hovered A song like ished gare lown warls

thore Lark.

ding speci. Dwight as kiver westn(Uoues)." mmer resiMarch 28; Portage la irly all the March 20; abundant on prairies; trails along our route from Livingston to Fort Pilly and down on the west side of the river, in company with Lap Longspurs, first half of September (MacouII). Carberry : Abundant summer resident; breeding nine each seasou!; resident, except during December, January, and February (Thompson). Two R:vers: 1884; arrived March 23 (Criddle). Brandon: 1882, March 20 (Wood). Shell River: 1885, first seen, fifty, on May 23; coinmon in flocks going north; a trausient risitaut; not breeding (Calcutt). Qu'Appelle: Common summer resideut; arrives April 1 to 25 (Guerusuy).

On May 12, 188\%, at camp 8 miles south of Brandon, midway between our tent ancl the fire 10 feet away, I started a small lird from its nest. It ran away very reluctantly, and continued wistfully close at haud, runuing about umong the tufts of grass in the glare of the fire, and returning each time as soon as it dared. At gray dawn I fomml her on the nest again; she slowly walked away when I approachell to rekinclle the fire, bnt returned almost inmediately with her mate; and now, for the first time, I saw them plainly. They were a pair of Shore Larks. Enconraged, no doubt, by the presence of her mate, she once more crept up to her nest and took np her position on the eggs, al. thongh I was but $\sigma$ feet off. Frying our bacon over a brisk fire, I was very careful to avoid hurting the birds or their home; and breakfast being over, travelers, tent, fire, aud horses all went off and left them to discharge their duties in peace. The nest contained three brown eggs; it was sunken in the ground, and was mude of grass and fiber, and lined with two or three large feathers.

My first real acquaintance with the Shore Lark at his home was in Minnesota, in the last week of March, 188:. A fearful blizzard, of course "the worst ever known in the country," had been raging for two days or more. On the third day, when it was nearly over, I was making my way out to see to the cattle. All the fences and low buildings were buried in snow, but the tall form of an elevator loomed up out of a circle of bare ground, caused by the eldying of the blast, and here, in the very vortex of the storm, in the thickest of the fight, were three or four little Shore Larks, hracing themselves against the driviug wind and picking up the seerls that had been exposed loy the displace. ment of the snow. Poor little things! I thonght, you must be nearly at death's door; buit even while I looked one of them, under the lee of the building, perched himself on a frozen clod and poured out his sweet, simple little song in a way that seemed to say, "How happy an I."

But the longest night will end, and it is not always winter, oven at the Pole. The spring comes, and "the time of the siuging of biris" arrives, and the browu Shore Lark raises his horus with sprightly air, and those who may chance to see him are now remindel that he is a near kinsman to the famerl skylark-that inileel he is a skylark. Thus far be hus sang only while perching on some clod or stone, but now 
the ardor of his devotion to the demure little quakeress by his side demands a more ambitious demonstration; so, ceasing to sing, he strenuonsly endeavors to associate with the white piling cumuli, and having soared, apparently, near enough to be uncomfortably damp, while to us he appears a mere speck, he floats on vibrating wings, singing a song composed of a single note, oft repeated with lessening intervals; it may be suggested by the syllables trick, trick, trick, trick, trick, trick, t.r.r.r.r-r.r.r.r.r.r," the notes at last all ruuning together like the drumming of a partridge. During this performance he has lost much of his altitude, but at once proceeds to regain it by a series of bounds before again repeating the song. This alternate souring and singing is usually kept up for over ten minutes, then the musician, having exhausted his energy, suddenly stops and dashes down with one frightful headlung pitch, right into the grass. Upon going to the spot one is surprised to find he has not been dashed to atoms by the violence of the fall, but springs up, uttering his usual call note, and flits further off, again to settle on the ground.

The whole of this performance will be seen to resemble very closely the serenade of the Missouri Skylark, the chief difference being that the Shore Lark is inferior in music and staying powers, and also in that the latter remains more nearly over one particular place. Another point of dissimilarity is, the Shore Lark sings chieffy on the ground, while the skylark confines his effusions almost entirely to his moments of physical elevation.

The Shore Lark is the earliest of the prairie siugers to begin in the morning, being even a little earlier than the Meadow Lark; it com. mences before there is any sign of dawn, and at vight, it continues uutil the plains are enveloped in perfect gloom.

But singing will not multiply the species, anil the two little "Quak. ers," as they are often called, set about nesting ere jet the snow is gone. Not seeking the shelter of bush or bank, but right out on the open prairie, on the level, they scrape a hole about an inch deep, then line it with grass and perhaps a feather or two from their mortal enemy, the hawk. In this are laid four or five brown eggs, freckled all over. This species has a curious habit, in common with the Baywing Bunting, of running on the road just before one and fyiug a little further on when overtaken. The Shore Lark does not usually repeat the maneuver more than twice or thrice, and frequently it suddenly squats and renains so until nearly within reach, when it springs up uttering its triple call. note and flies away to one sicle.

My observations incliue me to believe that in Manitoba the species raises two broods each season.

157a. Otooorls alpentria. Shore Lark.

Fall migrant. Specimens of the true alpestris were taken by myself at Rat Portage and at Oarberry in the fall (Thompson). Severn House: It appears common (Murray). 
his side sing, he muli, and bly damp, ng wings, lessening rick, trick, together ce he has oj a series to souring the inusi. shes down pon going to atoms call note,

ory closely being that lso in that Another he gronnd, 8 momonts

gin in the ; it com. inues nutil

tle "Quak. he snow is out on the deep, theu tal enemy, d all over. g Bunting, further on maneuver ud remains triple call.

he specips

by myself ern House:

\section{Pica pica hudsonica. American Magpie.}

Rare, and found chiefly in the west. Rare; resident in the woods about Lake Winuipeg; have a single specimen taken 30 miles east of Brandon (Hine). One at $\mathbf{Y}$. . $k$ Fort (Hutchins). I have noticed these in western Manitoba only (Hunter). I was informed that this bird was not uncommon in the woods near the Assiniboine River, 20 or 30 miles west of Portage la Prairie, abont fifteen years ago; but since that they have entirely disappeared (Nash). Have been told of its occur. rence at Fort Ellice in the winter of 1881 ; did not see it; Upper Assini. boine, September 27, 1881 (Macoun). At Fourth Lake, Qu'Appelle: "Magpies are very numerous in the thin woods fringing the lakes," 1858 (Hind). Qu'Appelle: Occasional; plentiful 100 miles north (Gnern. sey). Only stray indiviluals passing to the eastward of the Mississippi or of Lake Winnipeg. * * It does not entirely quit the banks of the Saskatchewan, even in winter (Richardson). Magpie first seen on the 7th of October at Mosquito Point, where the Belted Kingfisher was last seen; observed occusionally at Carlton, whery it resides in the winter; not seeu between Hudsou's Bay anil Lake Winnipeg (Blakiston).

She pe cum memewuck : the Magpje of Pennant. This bird breeds in trees; are plenty in the interior parts of the country, and a few are found near the southern settlements. In my twonty years residence in Hudson's Bay, I never knew them migrate to York Fort or Severn; only one was cnught in a marten trap at York Fort. I don't think they migrate any distance, as our people met them inland at all seasons. (Hutchins's MSS., Observations on Hudson's Bay, 1782.)

\section{Cyanocitta oristata. Blue Jay.}

Tolerably cominou summer resident in woodlands; very abundant at Pembina (Cones). Pennawa River, September, 1857 (Hind). Breed. ing near Lake Winuepeg (D. Gunn). Swampy Island: 1885, common, resides permanently; they go to the south end of the island in sum. mer to breed (Plunkett). Winnipeg: Summer resident; tolerably common (Hine). Oak Point: Arrived May 29, 1885; frst seen, a flock of eight that flew overhead ou May 24; next seen, three on May 25; a letter to Professor Cooke mentions that (February 6, 188n) two remaincel all winter about the place, and became quite tame (Smali). Ossowa: Coininon; bruediug; 1885, last seen, one on Oetober 19 (Wagner). Portage la Prairie: Common; resident; the wajority leave this locality in the winter, but I have seen some in every month in the year (Nush). Curberry: Tolerably common summer residents; breed. iug. Rat Portnge: October (Thompson). Arrives early in April, departs late in November (W. G. A. Brodie). Found at Red Deer and Swan Rivers, September 2, 1881 (Ilacoun). Shell River: 1885, first seen, two, ou May 15; next seen, three, on May 24, going north; a transient visitunt; not breeding here (Oalcutt). Qu'Appelle: Tolerably common summer resident; arrives $\mathbf{M}^{6}$ (Guerusey). A specimen 
from Red River Settlement in Smithsonian Institution; I noticed the absence of it on the route between York Factory aud Lake Winnipeg (Blakiston).

160. Perisoreus canadensis. Canada Jas. Whisky Jack. Wis-Ka-tjan.

Common resident in wooded sections, especially among evergreens. Winnipeg: Summer resident; tolerably common (Hine). Red River Valley: Common resident; they breed here (Mranitoba) in the month of March (Hunter). Resillent locally at Portage la Prairie; very scarce (Nash). Very abnutlant in all the wooded conntry examined in 1881 (Macoun). "Whisky Jack numerous ou the Scrub Oak lidge," near Dauphin Lake, October 9 (Hind, 1858). Uarburry: Common resident; breels in the spruce woods to the south; Dnck Monntain; Two Creeks, on Upper Assiniboine; Rat Portage, abundant (Thompson). Shell River: 1885; winter visitant (Calcutt). Severn House (Murray). Com. mon at Oarleton (Blakistou).

On October 13, 1883, at Two Creeks, west side of Assiniboine, I was awakened in the moruing by a Whisk J.Jack screaming close to my head. One or two of these birch have been in attendance at each of our camps since we came to this comparaticely wooded region, to feast on the camp scrups, which we have always been careful to put where the birls could easi'y get them.

On June 11, 1884, at Duck Mountain, I found the yonng WhiskyJohns following their parents through the woods. One of these, which I shot, was all over of a very dark bluish gray, tinged on the wings and tail with a glancous shade, which at once remindel me of the relation. ship existing between this birl and the Blus Jay. The noises which this family male were curious and varied. I have long ago learnt to ascribe to this species any unknown squeaks or wails that are heard in a spruce wood.

Novomber 8: Whisky.Johns came as nsual to our camp fire to day. They helped themselves to scraps but a few feet from me, and ultimately oue alighted on the pot stick and took off a scrap of meat that $1 \mathrm{l} \cdot \mathrm{ft}$ there, although it wis but a foot above a hot clear fire.

vhile moose hunting on December 6 we had crawled close to a herd, when sudilenly the loud screaming of the Whisky.Jack was heard, and before we could get a glimpse of them the moose had sought sufety in Hight.

During the numberless times that I have cumperl in the wiuter wools of the northwest, I bure hardly ever fuiled to bave the Wiskachon for a companion. Sometines $I$ have been awakened in the morning by the melancholy wailing of the bird a few inches from my head. Many a time I bave ferl it with scraps placed in such situations that its conrage would be sorely tried before it could secure the dainties. Once I laid a piece of meat on the snow between myself aud my companion. After one or two approaches the bird ruc 1 in and seized the morsel. Then I laid 
pticed the Winnipeg

Ka-tjan.

vergreens. Red River be month ery scarce ed in 1881 dge," near resident; ro Creeks, a). Shell y). Com.

pine, I was ose to iny at each of n, to ferst put where

(Whiskyese, which wings and e relation. ises which o learnt to - Leard in

Ire to day. , and ultimeat that

to a herd, teard, and ; sufety in

Iter woonls rachon for ing by the Many a ts conrage ice I laid a After one then I laid a piece hetween myself and the fire some 6 feet away; this also was taken. Finally I stuck a piece on the eull of the pot stick, which is a stout stick propped up so that it affords support to a kettle over the fire; anl althongh by so doing the bird had to fly dowu within 6 inches of a hot clear fire, without hesitation it dashed in and secured the prize. Long experience bas taught it that a camp is a sure place for a feast, and as soon as the ax is brought into play to prepare the firewood it is nsual to hear the responsive "tay tay" of the Wiskachon ap. proaching from some distant part of the timber. This call note of the species is much like the ordinary cry of the Blue Jas, but it has several others that are distinctively its own; this includes the melancholy sobs and wails which, sounding so uncanny smong the gloomy evergreens, have surrounded the bird with an atnosphere of mythic interest. According to Archbishop Taché, Wesakedjas is the name of the coot and of the fabulous being who takes part in all Indian legends. Almost the only musical sound that I bave heard it utter is a metallic " ohuck ohuok," not unlike that produced by the robin. The unmusical notes are so nun erons that one is almost safe to attribute to the Wiskachon any un. accoutable screams that may be heard within the presence of a spruce woods.

In the winter of 1881-'82 I saw one of these birds at Burnaide, abont 12 miles from Portage la Prairie, the ouly one I uver obeerved near there. In Deceuber, 1834, I found them aloundant in the Riding Monntaine, where they exhibited all the familiarity noually attribnted to them.

In October, 1886, two or three frequented the woods on the bank of the Red River, but those were all I ever saw in that neighborbond.

Nearly all writere refer to the harah notes of this bird, bnt omit to mention that it has some remarkably pleaving ones also, much resembling those of the Black Cap Tit but rather londer than it ntters when traveling abont in small parties, and sloo when alone if it feels partionlarly pleased with itwelf.

I can quite understand why trappers should dislike this bird, as it often does a lot of mischief to the skin of any animal that it may find dead in a suare, by eating holes in it; bnt it is a great favorite of mine, and will alwaye be weicome to niy camp, in spite of his petty pilfering of eatables. (Nash, in MSS.)

\section{Corvus corax principalie. Northern Raven.}

Tolerably common winter visitant; probably nesting in the northe I" lands. Tolerably common winter resident along the boundary (Coues). Wimuipeg: Winter visitant; tolerably common (Hine). At Lake Win. nipeg (Keunicott). Red Rirer Valley: Resident, tolerably common more seen in winter than in summar (Hunter). "And in the sprnce swamps were several rav'ns," October 9; uear Scrub Ouk Ridge, Danphin Lake, Plains of the Souris, Jnly (Hind, 1858). Portage la Prairie: Very scarce; permanent resident ; in February; 1882, I saw one about 4 miles west of the city of Winnipeg, and on December 17, 1884, I saw tro in the Reding Mountains (Nash). Carberry: Noted only in winter; Rat Portage, common in fall (Thompson). Not observed in the Winnepegosis region, but frequent in the Western Plains (Macoun). Qu'Appelle: Uccasional (Guerusey). 
December, 1882 : During the past month or more $I$ have seen a raven flying over the plain. From the tracks in the snow I learued that it was one of these that robbed my wolf trap of the bait. When flying overbead it resembles a large crow, but may be distingnished by its frequent sailing and by its voice, which is much deeper and is not un. like the bark of a log, and it is from this I suppose that the bird is enlled "Barking Crow" by the Hudson Bay Company's employés. In the vicinity of Winnipeg it is a regular winter visitant, but when the spring returns it retires, probably to the rocky and timbered land in the region of the large lakes.

January 13, 1887, Rat Portage: Ravens continue as numerous as ever about the town. When unarmed one may sometimes approach within 20 feet of them. I subsequently saw the species in numbers at Schreiber's, north shore of Lake Superior (January 16), and at North Bay, Lake Nepissing (January 18), as well as at intervening points on the railroad. I observed it carrying food in its claws; and on one occasion, at North Bay, saw one transfer a bone from its beak to its claws and back again several times during flight. At Schreiber's they were particularly numerous and tame. Almost any strange, weird sounds, musical or harsh, heard in the woors there might, I found, be safely referred to the raven.

Raven (Corvus corax): Always to be seen; and so far from being a solitary bird, as it is called in Europe, I made a discovery in its habits of which I had no ides before. At the beginning of winter I observed that the ravens, which I saw abont sunset no matter where I was, were always flying towards the same point, and I conoluded there must be some large trees somewhere in that direction where a fow pairs, perhaps, roosted. One day, therefore, after having been out with my gun, I made a point of returning to the fort in the evening by that quarter. Judge ny aurprise when, among some clumps of young aspen trees, none of which was above 25 feet high or thicker than my arm, I found one of these clumps literally filled with ravens, which, on my near approaoh, took wing and commenced flying about in all directions. I judged by connting a portion that there were upwards of fifty in that one place; und that no one should hereatter say, "Oh, they were a lot of crows," I shot one, which I keep as a specimen. I have been to the eame spot on otber occasions during the winter and always found my black friends. It is wonderful with what regnlarity of time they repair to their roosting place in the evening and leave again in the morning, by paire, for their day's hunt. One pair flies directly over the fort each morning, and an I sit on watch for the minute haud of the chronometer to come ronnd to each hour of observation as magnetic observer; they give a croak as they fly over, as a morning salutation, I suppose; at any rate I give them the credit for such civility; and looking to see the time I fund it the same within two or three minntes, but gradnally earlier and earlier, for the enn, which is their olock, is each day lengthening his course above our horizon. The raven is only known by the name "crow" here. (Capt. T. Blakiaton, from Fort Carleton, 1858.)

162. Corvus amerioanus. American Crow.

Common summer resident of woorlands. A gool many along Mouse River, at the boundary (Coues). Dufferin: Arrived before April 15 (Dawson). Red River Settlement: In 1859, before 4th of April; speci.

men from nipeg: $\mathrm{Su}$ first seell, is common first seen, Lake anil : were able common o first seen April 16; end of $\mathrm{M}$ : became c Portage 1 March ; d 4 ; usuall: year (Nas dent; bre Two on A on March breeds he Shell Riv common : first seen, ninety-on Qu'Appe Station (

On Ju It contai much ex several $t$ or rathe it in a m would $b$ formanc remarka crows w

On A crows ; and let the floc make a bejond flock of quite b commu

On \$ 
n a raven ed that it hen flying ed by its is not un. d is called 3. In the the spring the region

merous as approach umbers at at Nortl points ou one occa. b its claws they were rd sounds, bo safely

tary bird, as Ides before. ut sunset no I concluded w pairs, pern, I made a niy ourprise 25 feet high vith ravens, I directions. t one place; I shot one, sions during t regularity gain in the in fort each comeround hey fly over, or such civ. ninutes, but I lengthenme "crow"

ng Mouse April 15 il ; speci- men from Nelson River in Smithsonian Institution (Blakiston). Win. nipeg: Summer resident; abundaut (Hine). Swampy Island: 1885, first seen, two, ou April 6; next seen April 7, when it became common; is common all summer, and breeds here; last seen September 29; 1886, first seen, two, on April 6; bulk arrived April 8 (Plunkett). Cross Lake and at Lake Winnipeg (Kennicott). On Lake Winuipeg the young were able to fly in the beginning of July; not often seen in the woods; common on Budson's Bay (Bell). Ossowa: Comunon; breeding; 1885, first seen, one, on March 29; next seen, April 10; became common April 16; last seen, one, on December 12 (Wagner). 1884, arrived end of March; 1885, first seen, one, on Marcli 28 ; next seen on 29th ; became common ou April 10; is common and breeds here (Small). Portage la Prairie: Common summer resident; arrive at the end of March; depart abont the middle of October; in .1884, first seen April 4 ; usually these birds come before the snow goes, bnt were late this year (Nash). Carberry : Abuudant ill migration only; summer resident; breeding at Fairview and at Binscarth (Thompson). Brandon: Two on April 10, 1887 (Wood). Daltou; 1889, frst seen, three or four, on March 27; next seen on March 28; became common on April 8; breeds here (Youmans). Common on the Western Plains (Macoun). Shell River: First seen, flve, on April 3; seen every day afterwards; common summer residant; breeds here (Ualcutt). Two Rivers : 1885, first seen, two, on April 2; next seen, April 3, when it became common; ninety-one seen in one flight; fairly comnon and breeds here (Criddle). Qu'Appelle: Common; breeds April 1 to 5 (Guernsey). Trout Lake Station (Murray). Common all winter at Carleton (Blakiston).

On June 27, 1882, at Fairview, found a crow's nest in a poplar tree. It contained four fully fledged young ones. The old birds were very much excited. They flew about, cawing loudly. One of them alighted several times on a branch but 6 feet above my head, and, while cawing, or rather croaking, vigorously seized a twig in her bill and worried at it in a most savage manner, as though to indicate the treatment she would be glad to have me receive. Her voice during this cnrious performance was almost like a growl. Having noted that the nest was a remarkably strong, warm structure, and that the eyes of the young crows were blue.gray, I left the family in peace once more.

On August 30, 1883, on the road, I saw a flock of about two hundred crows; they appeared to be migrating. They were remarkably tame and let me approach them within 10 feet; of course I had no gun. With the flock were two brown harriers; once or twice I saw one of them make a sort of a stoop at a crow, but the latter took but little notice bejond moving a little further off. Later in the day I saw another flock of about thirty crows, and with them oue brown harrier, who quite behaved as though he were a reputable member of the crow community.

On September 7, a boy brought me a living crow that he had winged; 
its npper mandible was bent in the middle at right angles nearly and pointed downwarl, crossing the other, which was straight at one side. I kept it alive to see how it fed; it was able to pick up breal from the tloor, but at each bite it had to turu its head, with the crown to the ground; when killed it proved to be quite fat.

On Jume 6, 1884, at Binscarth, on the Upper Assiniboine, I found a crom's nest in a bluff of poplar trees. It was in a crotch of a laige poplar, about 8 feet from the ground, and was one of the most beauti. ful specimens of bird architecture I ever examined, excluding, of course, all pensile nests. It was a large structure of sticks, twigs, and bark strips, with a very leep carity lined with fiue flbers and beautifully finished off with a coating of cow's hair. It contained four eggs.

Ha ha sen: The crow. These birds are plenty inland but seldom appear on the coast. " " This bird is nigratory. (Hutohine MSS., Observations on Hud. son's Bay, 1782.)

163. Dolichonyx oryzivorus albinucha. Western Bobolink. Whito-naped Bobolink.

Carberry: Specimens are referred by Mr. Ridgway to the form albinucha, therefore I asaume this to be the form throughout. Com. mon summer resident on the prairies; at Pembina, breediug in large numbers, and westward aloug the boundary to the mountains (Coues). North to Selkirk Settlement (Ridgway). Winnipeg: Summer resi. ilent; abundant (Hive). Stony Mountain: In every little bluff of uspen or willow the leautiful rice bird (Dolichonyx oryzivorus) was seen or heard (Hine). Ossowa: Breeding (Waguer). Oak Point: 1884, arrived May 23 (Small). Portage la Prairie: Common sun. mer resilent; arrives about the 20 th of May ; departs the end of Sep. tember; in 1884, first seen, June 1 ; last scen, July 22; at this date they were changing their plumage and gathering into flocks (Nash). Car. berry : Common summer resident near Turtle Mountain; near Long River (Thompson). Dalton: 1889, first seen, five, on May 22; breeds here (Youmans). Quite common on the prairies in Manitolo, from Grand Valley to Cypress Hills (Macoun). Shell River: 1885, first seen, one, male, on May 18; next seen, ten, ou May 24; is common all summer and breeds here; nest with six eggs found (Ualcutt). Qu'Appelle: Tolerably comnon summer resident; breeds; arrives May 15 (Guernsey).

July 25, 1884: Bobolinks still in brepding plumage at Carberry, althongh at Portage la Prairie I noted them changing three days ago, lout carly in August the change takes place, and Bob discards his motley and bells. The play is over, the clown of the panttomime lays aside his license and livery, and, like many real clowns out of dress, he is a very serious character. He is now silent, or only utters a metallic "klink" and goes very intently about the very prosaic business of finding ont where, with least tronble, he can get the largest meals. 
pearly and $t$ one side. 1 froin the wn to the

I found a of a large ost beauti. of course, and bark beautifully ggs.

ppear on the ons on Hud-

-naped Bol.

the form put. Com. g in large ns (Coues). nmer resi. le bluff of vorus) was lak Point: mon sum. nd of Sap. 9 date they tsh). Car. near Long 22; breeds toba, from 1885, first ommou all ) Qu'Ap. res May 15

Carberry, days ago, is his motlays aside $\mathrm{ss}$, he is a a metallic usiness of meals.
The Bobolink (Dolichonyx oryzivorus) is of conree common. I saw birds in both the black and buff plumage together at Carberry on August 30. (Christy.)

Towards the end of July, after breeding, these birds collect into large flocke, and the old males change their plnmage. They then leave the prairie and attack the oat fields, doing, with the assistance of the Grackles uni Rering Blackbirde, an inmense amonut of mischief. After the oats are cut they resort to the marshes, feeding on wild rice, etco, until the cool nights inform them it is time to leave. (Nash, in MSS.)

164. Molothrus ater. Cowbird.

Abundant summer resident thronghout the prairie regions. Abun. dant at Pembina and westward along the boundary to the mountaius (Coues). Red Kiver Settlement on 28th April (Blakiston). Winuipeg: Summer resillent; abundant (Hiue). Oak Point : 1886, arrived April 14; 1885, frst seen, one, on April 15; is common, and breeds here (Small). Ussowa: Breeding (Wagner). Portage la Prairie: Oommon summer resident; altogether too abundant; with the same parasitical babits in vesting as elsewhere; arrives about May 25; departs in the early part of October (Nash). Carberry : Abundant summer resident on the prairies; Souris River, May (Thompson). Common everywhere on the prairies (Macoun). Shell River : 1885, first seen, five, on May 14 ; afterwards sceu every dav all summer; is common; lays eggs in the nests of the Song Sparrow and Yellow Birl (Calcutt). Qu' Appelle: Common summer resident; breeds; arrives April 20 (Gnernsey).

I noticed that on the Big Plain the cowbirds disappear for a time, apparently joining the rusty grackles aud other species among the swanips and wet lauds until after the attainment of the fall plumage, when for a time they again became conspicuous, aud continue abont the pastures until October.

165. Xanthocephalus zanthooephalus. Yellow-headed Blackbird.

Common summer resident of the deeper slonghs of the prairie regions. At Pembina, breeding abundantly; Turtle Mountain and Mouse River at the boundary (Coues). Dufferin : Arrived between April 25 and 30 (Dawson). Winnipeg: Summer resident; abundant (Bine). Shoal Lake: May 15, 1887, very abundant (Christy). North to fifty-eighth parallel, but not to eastward of Lake Winnipeg (Richurdson). Ossowa : Breeding (Wagner). Oak Point: 1834, arrived May 5 (Small). Portage la Prairie : Common sumıer resident; arrives about May 1, departs early in October; in 1884, main body arrived May 6 ; some few came before this (Nash). Prairie Portage (Hind). Carberry: Rare summer reșilent; Brandon (Thompson). Two Rivers: 1885, first seen, two, on May 1; fairly rare (Criddle). Dalton : 1889, tirst seen, two, on May 4 ; next seen on May 10, when It became common; breeds here (You. mans). Alundant around pools and marshes from Pembina to Winuipeg, in sedgy ponds, west to Mnose Mountain ; not noted ill Winuepegosis region (Macoun). Shell kiver: 1885, first seen, one male, on May 
1; next seen, four males, on May 3 ; is common here all summer and breeds, nesting in the bullrushes (Calcutt). Qu'Apelle: Common snm. mer resident; breeds ; arrives April 18 (Guernsey.)

The voice of this bird is somewhat like that of the redwing, but is more varied, and in many of its intonations presents such a curious resemblance to the human voice as to suggest the possibility of its learning to articulate words. Its distribution is regulated by the amount of sedgy marsh in a neighborhnod; thus, south of Winnipeg it is exceelingly abundaut, and at Portage la Prairie it is very common ; but in the immediate vicinity of Oarberry it is the least common of the blackbirds. In its nesting and general habits it somewhat resembles the redwing, but is more terrestial and less disposed to haunt willow sloughs.

Arrives about May 1; departs early in October. A frost just sufficient to form a thin coat of ice on standing water, on the night of October 6, 1884, drove out the whole urmy of these birds and all kindred species that roost in the reeds of the sloughs. I watched them in to roost that evening, as usual, but at daylight the next morning they had gone, leaving only a few straggling grackles behini.

Does not occur east of Long Lake, a sheet of water about 22 miles west of Wimipeg, near which city I could not fiud it or hear of it, although the country seems to be just suited to its want. (Nash, in MSS.)

166. Agelaiun phonniceus. Red.winged Blaokbird. Soldier Blackbird.

Abundant summer resident, frequenting the willow.edged sloughs. Pembina (Coues). Commou at Red River Settlements (D. Gunn). Red River Settlement on April 26 (Blakiston). Dufierin: Arrived between April 15 and 20 (Dawson). Winnipeg: Summer resident; abundant (Hine). Ossowa: Common; breeding; 1885, frst seen, one, on April 25 ; next seen on April 26; became cominon April 28 (Wagner'). Oak Point: 1884, urrirell April 14; 1885, first seen April 18, next seen April 19; is common and breeds here (Small). Portage la Prairie: Common summer resident; arrive about April 15; depart early in (1ctober, though in 1885 a small party remained here until nearly the mid. dle of November, long after everything was frozen up; they frequented my garden, feeding on the sunflower seeds; when these were exhausted I saw no more of them; in 1884, first seen April 22 (Nash). Very com. mon in willow ponds in the Winnepegosis region (Maconu). Carberry : Abundant summer resilent; breeding near Shoal Lake, west (Thompson). Two Rivers: 1885, first seen, several, on April 16; next seen, April 17; became common, witt two other species, April 18 (Oriddle). Dalton: 1880, first seen, one, on April 13; next seen on April 15, when it hecame common; breeds here (Youmans). Shell River: 1885, first seen, thirty-oue, on April 13 ; afterwarls seen every day, male and fo. male, in flock; common all summer aud breeds here (Caloutt). Qu'Ap. pelle : Common summer resident; breeds; arrives April 18 (Guernsey).

June 11, 1882: Went in the morning with two brothers to the lake in the saud hills east of De Wintoll ; saw there large numbers of Marsh

Terns an of the wr but foun projecter feet from tification nest is $\nabla$ upright entirely 1 by $1 \frac{1}{6}$, brown.b

On $A_{1}$ redwing merous, leave th this sea

This c (Quiscal may be

Duriv ing the to his $\mathrm{fe}$ the gor to appe he is as mate su

The v heard $t$ iug stro that I

The Lappily by wha of Port pleasin it must other 1 joymen

Shor

but in sands Ootobe 16
Abu
way). 
mmer and mon sum.

ng, but is a curions ility of its d by the inuipeg it common ; mon of the resombles nt willow

t to form a cove out the $n$ the reeds but at day. kles behincl. t of Wiunitry seems to

ckbird.

d sloughs. inn). Red d between abundaut , on April 1er). Oak next seen a Prairie: trly in (1). $y$ the mid. requented exhausted Very comCarberry : $t$ (Thomp. lext seen, (Oriddle). (15, when 1885 , first le and fo. Qu'Ap. tuernsey). he lake in of Marah
Terns and various kinds of blackbirds. I was unable, from the depth of the water, to reach the place where the terus seemed to be nesting, but found the nest of the ked-winged Blackbire in $n$ few twigs that projected about a foot above the water, here 3 feet deep, and some 10 feet from the shore. I saw the female leave the nest, so that the identification is good. The male did not put in an appearance at all. The nest is very deep, neat, and strong ; it is suspended from about a dozen upright twigs and is built much like that of a Baltimore Oriole, but entirely of grass. The eggs, four in number, were all fresh; one was 1 by $1 \frac{1}{8}$, pale blue, and scrawled over with most curious hieroglyphs in brown-black ink; the others were similar.

On August 9, 1884, while at Humphrey's Lake, I noticed that in the redwing colony there, although females and young birds were very uumerous, only one male was to be seen. It would seem that the males leave the scattered breeding places and repair to the great marshes at this season and later on the females follow with the young.

This cnrious habit is said to belong also to the Boat.tailed Grackle (Quiscalus major), while the late summer disappearance of the cowbirds may be a propensity somewhat similar in its nature.

During the courting seasou the male Redwing may be seen approaching the female in most beseeching attitudes and giving rocal expression to his feelings from time to time, while his wings are slightly raised and the gorgeous patch of scarlet feathers on the slioulder expanded so as to appear thrice as large as under ordinary circumstances. Doubtless he is as much indebted to the latter as to his vocal appeal for the ultimate success of his suit.

The usual note of the species is a short, harsh " chick," but it is often heard to utter a shrill whistle, during which I bave seen the bird dashing strnight across the field or marsh with a flight so steady and swift that I have sometimes wondered for a minute what bird it was.

The "song" of the Redwing is a sort of guttural squeal; it has been Lappily syllabilized as "conk-que-ree." The effect of this, when uttered by what seemed to be a million voices, as I heard it among the reed-beds of Portage la Prairie slough, is not unmusical, and to the naturalist is pleasing in its significance of the multitudinous life about him, though it must be confessed that the granivorous propensities of this and all other blackbirds leare little chance of the farmers finding a similar enjoyment in the pleasant aggregation of unpleasant individual notes.

Shortly after the end of August all the species disappeared from here, but in snch large reed-beds as that mentioned above they gather in thou. sands and linger until the frost drives them south, about the middle of Ootober.

167. Sturnella magua negleota. Western Moadow Lark. Prairie Lark.

Abundant summer resident of the prulries. East to Pembinn (Ridg. way). Pembina, and westward aloug the boundary to the Rockies; com. 
mon (Coues). From 60 miles south of Red River Settlement (Blakiston). Dufferin: Arrives between April 25 and 30 (Dawsoul). Winnipeg: Summer resident; abundant (Hine). Ossowa: Common breeding; 1885, first seen on April 6; wext seen April 15; became common on April 19 (Wagner). Shoal Lake (Guin). Shoal Lake: May 16, 1887 (Ohristy). Oak Point : 1884, arrive May 17 ; first seell, one, on A pril 9 ; next seen on 10th; became common ou 13th; breed here (Nmall). Portage la Prairie: Common summer resicient; arrires about April 10, departs alout the middle of October; in 1884, first seen, April 15: in 1883 saw it in March (Nash). Carberry and the Big Plain, generally, to the Fingerboard; common summer resident near Turtle Mountain, Brandon, Milford (Thowpson). Abundant on the prairie aloug the ronte marked; not seen in the Winnipegosis region (Macoun). Two rivers : 1885, first seen, one, ou April 16 ; uext seen, $A$ pril 17 ; fairly common; breeds (Oriddle). Dalton : 1889, first seen on Mareh 26 ; next seen on March 28, when it became cummou; breels here (Yuumans). Shell River: 1885, first seen, one male, on April 12 ; a counmon summer resident, and breeds here (Calcutt). Qu'Appelle : Common summer resident; breeds; ar. rives April 5 ((iuernney).

April 17, 1882 : The prairies are showing brown in places, and soow. banks are settling and losing their whiteness, through the grass that begins to show through them. Three Meadow Larks alighted on the fence to das, quite near to me, and one of them delighted me by rocife. rating his short rich song with a beauty I never before beard.

April 18: Un Sunday we saw a few Meadow Larks about; on Monday the number nas increased and an occasional jingle was heard; but to. day (Tuesday) at dawn scoles of larks had alpeared, and, as if by coucert, all together burst into an explosion of splendid song, gushing out their rich, stroug warblings from every little height and perch, singing with all their might; singing, as if under p:essure; sing they must; perched on a ience, perched on a clod, runting on the ground or Hying high in the air, they sing aul must sing aloul for the spring ; singing they saw-the dawu and the noou and the evening, nnd still they sang on till vight came und the prairies were hidden in darkness, then for a while they censed; but the rising of the yellow moun above the eastern friuge of trees was loudly bailed by many of the joyous biris and greeted with a renewal of this morning's burst of song.

April 27: Fall of silow last night, but this morning it changed to rain, and by 10 a. m. no snow remained. A Meuduw Lark contrived to sing in all the peltiug shower; ne was not 100 yarls from the door; so I took the telescope, paper, and pencil and mule a sketch of him.

May 5: Took specinl nutes on the position of Mealow Larks while siuging to-day. Altogether, I observed tweive that were in fill song; of these, nive were singing on trees, two in the air, and one on the gronnd. Their song, when on the wing, is eutirely difterent from that while per Skylark.

Jnne 4 a Prairie lark had only 2 or most like on it. $\mathbf{T}$ June 17,

On Jur same tim and laste ell masse mastery. whose fa

Un Ju stomach yellow or streaks. parently the bird

Plain so Meadow L plains, an ally perch the hante

How lius uone wo find are gatl Europer justice $t$ but thos to obser their ke to $\mathrm{my} 0$ the plai

For 5 glorious nighting of Baffr Englan as a ot: 
lakiston). innipeg: ing; 1885, on April (Ohristy). next seen ortage lia , departs 1883 saw $y$, to the Brandon, marked; 1885, first ; ; breeds on March ver: 1885 , nd breeds eeds; ar.

and snow. grass that ced on the by vocife-

n Jonday d; but to. , as if by , gushing ad perch, sing they 10 ground 10 spring ; and still darkness, on above he joyous ong.

langed to atrived to 10or; so I m.

rks whlle full song; 18 on the from that while perching; it is more like the prolonged trilling of the English Skylark.

June 4: Found a Meadow Lark's nest about 3 yards from the nest of a Prairie Chicken. This latter I had frequently visited, so that the lark had probably watched me on several occasions from a distance of only 2 or 3 yards, and yet had not betrayel her charge by flincling, and most likely I wonld not have found it had I not chanced to step uearly on it. This nest now contained soung ones. I watched them until June 17, when I found they had flown.

On June 2, 1883, I saw four Meadow Larks all fighting, and at the same time singing in the air together. It was a curious competition and lasted for a minute or more; then down into the grass they dived ell masse, there to continue for several winutes their noisy battle for the mastery. Possibly one of the number may have been a femile, for whose favors the rest were competing.

On July 30, Miller Christy shot a young Meadow Lark, a male; stomach flled with iusects, apparently ail coleoptera ; it hal very little yellow on the breast, and the crescent was represented only by a few streaks. On its breast was an ulcer that nearly reached the bone; ap. parently it had been caused by a barb of a wire fence, agaiust which the bird must have flown within the last fortnight.

Plain south of Bhosl Lake, June 22, 1867 : In passing over the plain we shot a Meatow Lark. These birds are found in pairs along the Rol River to the end of the plaius, and on the south side of the Asoiniboine. They appenr in pairs in May, generally perched on a luw tree, willow, or reed. They are very watchful, seidom allowing the hanter the chance of a fair shot. (D. Gunu.)

\section{THE SONG OF THE PRAIRIE LARK.}

[Roptoduced from the Amorican Magazine, April, 1887.]

How often and often we bear the hackueyed statement, "America lins none but scentless flowers and songless birds," and how invariubly we find that it proceeds from persons whose ideas of birds and flowers are gathered wholly from books and magazines, and these chietly of European origin! There are many able writers ready and willing to do justice to the beauty and the fragrance of our numberless wild flowers, but those whose opportunities anil dispositions enable them perfectly to observe and completely to record what of bird-song comes within their ken are few in number. For thla resson I wish to give publicity to my observation of the Western Meadow-lurk-the sweet singer of the plains, and the moxt gifted of American feathered musicians.

For years the skylark of England was my familiar friend, and his glorious sung was my daily joy. Many times have I heard the fimed nightingale singing by mooulight and by daylight in the shaly wools of Suffron Walden, in Essex, and nearly all the noted songsters of Hngland beoame more or less faniliar during a sojourn of suverul years as a stranger in my natire land. Then came a change that bronght 
me once again among the birds of my boyhood-those of Canada, ms home-and also for the first time enabled me to hear the song which has given me such unallosed delight.

It was springtime in Manitoba; the season of blizzards was nearly past, but the prairies were still buried deeply out of sight, and the north wind was yet howling over the plains. We were looking for signs of spring, but I was not prepared to hear, from the very bosom of a gale, a loud, melodious chant, short and sweet oh-liow sweet after the long silent months of wiuter! "There's the lark!" cried my more experienced brother. Yes, it was the lark, the herald and king of the host of singers that were now at length coming home agaiu from the south. As I knew the Meadow Lark of easteru America, and wis acquainted with its short and rather ordinary song, the ascription of such a burst of melody to a Meadow Lark seemed rather surprising; but before that summer was over I had fonnd out that the prairie birl is very widely different in voice, powers, habits and all but appearance from his near kiusman in the east.

On the day after the initial spring greeting the weather was pleasanter; other larks were to be seen, and an occasional warble was heard. The next day at dawn scores of larks had appeared, and as if by con. cert, all together burst into a splendiul explosion of song, pouring out their rich, strong voices from every little height and perch, singing with all their might. Standing on a clod, runniug on the ground, or flying ligh in the air, they sing and must sing aloud for the spring. The dawn, the noon, the evening passed, aud still they sang; not till night came on and bleck darkness covered the plain, did they for a while cease; bnt the rising of the yellow moon above the eastern fringe of trees was loudly hailed by uany of the joyous birds, und greetel with a renewal of their morning bursts of song.

All through that spring and summer 1 had ample opportunities of hearing and studying the music of the delightful Prairie Lark. Nor did I forget to make what record I could of his varied chants, that I might mure accurately describe them afterward. Some of them I give in musical notation, though indeed the bird does not sing strictly in the music of our scale, nor does there usually appear to be any true recog. nition of time.

The first, the short warble of spring-time, is nearly thus:

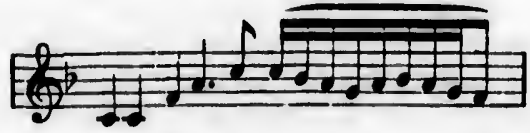

Varied and replaced by another:

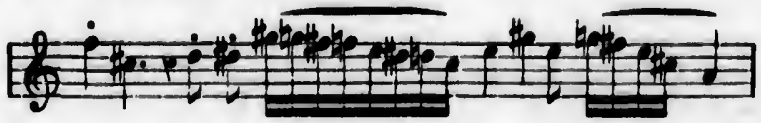

strecee 
nada, my ong which

as nearly , and the oking for ory bosom weet ufter oried $m y$ and kiıg gain from $h$, and wiss ription of urprising; rairie birl ppearance

ras pleaswas beard. if by con. buring ont b, singing ground, or the spring. g; not till they for a tern fringe d greetel

tunities of jark. Nor nts, that I hem I give ictly in the true recog.

Or one yet more characteristic:

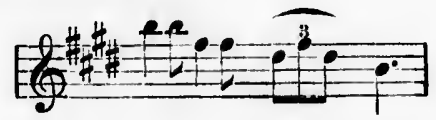

And also, as the season advanees, by in third and longer ehant:

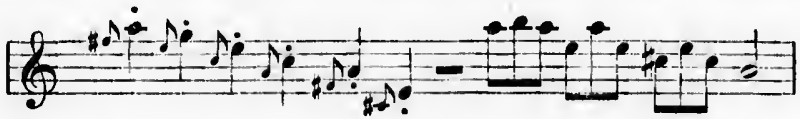

These bars, reproduced on a flute, will suggest with fair aeeuraey the mere notes of the song; but they can not suge. st the bleak prairie seene nor the blizzarel that livils to drown the singers's roiee; nor the long, silent months gone by, without which the life and meaning and true feeling of the stirring cull enn not be unclerstood.

As the full springtime comes on, the number of these short ehants is greatly increased, whilst their prolongations and variations are withont number; and soon it becomes evident to the most casual observer that the love-fires are kindling, and tinat each musician is striving to tho ntmost of his powers to surpass all rivals and win the lanly lark of his ehoice. On one occasion, as I lay in hiding near a fince, three larks eame skimming over the plain. They alighted within a fow yards of ine, and two of them burst into song, sometimes singing together ancl sometimes alternately, but the thirl was silent. When at last they flew up I noticel that the silent one and one of the singers liept together. I had beon witness to a musical tomrnament and tho victor had won his bride.

Nor does the lore-fire langnish after mating; for now the lark is inspired anew, and springing up from the grass he soars high in the air and pours forth a rhapsody that seems to flood the very plains with sound-ringing and bursting; richer far than song of nightingale; pro. longed like the skylark's melody ; will with passion and fire, aul more varied than tongue or type ean tell. Often lawe I tried to record the changing bars of music, but nover with any but tho most tritling success. A few of the notes were cunght, but the volume of the song was far beyond the power of symbol or stait to represent. Commonly the refrain began with a part nearly thus:

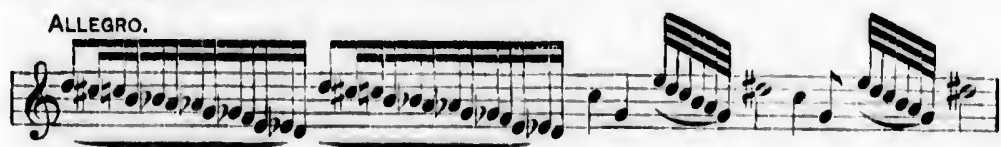

succeeded after severul repetitions by inother:

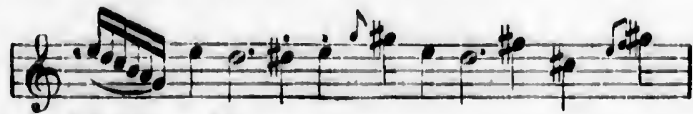

Proc. N. M. $00 \longrightarrow 37$ 
All after that was a torrent of melody beyond any mode of expression at my command, until the fiual bar with thute-like clearness is rendered and ropeated :

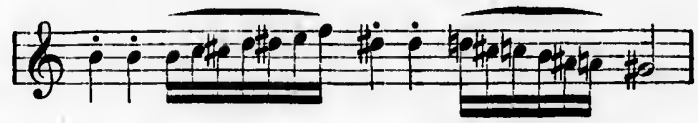

and then the singer sails downward to the prairie where sits the one for whom alone was meant this passionate strain.

There is yet one more type of song with this bird. It is a prolougen tender warbling, quite unlike the far-reaehing elants, for it is so low and soft that at a hunclred yards distance it becomes inaudible. I have heard it only a few times, and then it was uttered by the male bircl, standing on some low perch not far remored from the nest where his less mnsical though not less beautiful mate was brooding.

Thronghout the nesting season the air-song and the gentle coujugal refrain may be heard in full strength, for love is the life of their melody; but after the young hive flown these are heard no more, though still the ehorter lays are nttered daily and hourly from the fow low perches offered by the pruirie.

During the heat of summer, when other birds are bushed, the Prairio Lark eontinues in soug both by day and by night; and even when chill October draws nigh, he still lingers on the prairies and warbles in the brown grass with much of the power and sweetuess of springtime. The latest seasonal observation that $I$ have of the bird was of one singing a farewell to the already snow-whitened plains late in October, after which he took wing, and I watched him till out of sight in the southem sky.

How comes it that this prince of songsters has so long continued almost unknown? Why aro we of the nuw world so heedless of our native singers? Had sueh a voice been brought. forth in Italy, its praises would have furnished a worthy theme to many. a noble pen:

And Ovid, could ho but have heard,

Had huug a legendary pain,

Abont the mention of the bird.

True, I find on reference to stundard works of natural bistory' brief uotes in connection with our bird, such as "One of the most delightful voices of the prairie" (Coues); "Impressed by its wouderful betuty of song" (Brower); "Their songs are lively, sweet, and varied; they sing at ull seasons, carly and late, from the grounl, from the treo-tol, mul in the air" (Cooper); "Highly musieal, contending even with the mocking-bird for supremacy in song" (Lieutenant Oonch); "In the depth of its tone and the churms of its articulation its song is hardly excelled" (Riilgway).

And yet so inaderjute is tho power of mere words, that, though I lud previously read these opiuions, I was wholly taken by surpriso when 
oression rendered

the one

rolonged is so low

I have ale bird, there his conjugal of their no more, from the

he Prairio when ehill les in the me. The singing a fter which hel'n sky. continued ess of our Italy, its lo peu:

tory ${ }^{\circ}$ brief delightful beauty of ied; they tree-top, a with the "In the is hardly

ugh I hat rise when first on the prairies of the Assinaboine I heard the voice of the Meadow. Lark of the West.

One writer compares it will the rich-voiced wood-thrush; another, with the gifted mocking-bird, a:d again parts of its song have been likened to the soft warbling of the blue bird. But nearly all of this qualified praiso is from the peu of passing travelers, fow of whom have, like the writer, spent season after season with the bird, hearing its spring greeting aud its fall farewell, resting so near to its nest as to hear its vesper warble, its midnight song of peace, and its salute to dawning day. Few have actually witnessed the soug contests of the rival birds, and fewer still have overheard the soft eonsoling lay of the male to his sitting mate.

In listening to each of these varied effusions again and again, I have been pecnliarly fortunate, and each seuson spent on the prairies has intensified the admiration I felt for onr bircl for, though indeed it will not compare with the skylark in continuity of inspiration, it is second to nothing else. In richness of voice and modulation it equals or excels both wood-thrush and nightingale, and in the power and beauty of its articulation it has no superior in the whole world of feath. ered choristers with which I am acquainted. The more I hearl of its melody the deeper was the admiration with which it inspired me, until at length I have leirued to look on our lark as the noblest of birdmnsicians, and the very incarnation of the wild, free opirit of the West.

No birl is more characteristic of the prairies than the Moadow-lark (Sturnella neglecla). It is very conmon in summer and breeds abundautly. Its elear, musical whistle (almost, if not quite equal to tho song of the nightingale) is utterid by the bird oither whon upon tho wing, the ground, or a tree, and may bo hearl for a great distance. Towarls the end of August, though the birls hal not left, thoy had largoly ceased whistling ; but the arrival of a fow warm days, about the 10th of September, set them off again for a timo. When I loft, about the uniddle of Oetober, there werestill a fow small faully parties about. thougl the great majority bad gone sonth. It is decidedly a shy bird, oven in a conntry where most birds aro notably less wary than in England; and, common as the birl is, it is no easy mntter to obtain a specimen just wbon one wants. Late in July I slot a young specimen with a largo fostering soro on its broast, doubtless cansed by its baving aecilontally flown agninst a spike on one of the unmorous " barb-wire" fonces on which this biru frequently perehes. Not long after I shot a I'urple Gracklo witb an old wonnd ou its head, which was probably oceasioned by the same meaus. I have often thought what a copitul thing it would bo to introcluce the Mealow Lark into Englanc. So lar us plumage and noug aro concerned, it would take rank auong our brightest colorch and most almired songsters; while its hardy nature would allow of its remaining with us tho wholo year romml, ws imdeed it often does in Onturio and other districts farthor south thuı Munitoln. Porfectly harmessand ncenstomod to grassy countries, it wonld quickly become naturalized in our mealows, where it would find an abundmoe of Insect food, aud would doubtless soon increase suffleiently in numbers to scrve, if need ho, as a game and food bird, as it largely does in the United Strotes. No other songeter thit I ever heard equals this bird iu the sweotuoss aud mellowness of its notos. (Christy.) 
One malé specimen, June 6, 1873, at P'ombina, the only locality where observed (Coues).

\section{Icterus galbula. Baltimore Oriole.}

Common summer resident of open woodlands in the south and west. Abundant at Pembina; breeling; the only loeality where found along the line (Coues). Winnipeg: Summer resident; abundant; found not quite so far north as the Rose-breasted Grosbeak (Hine). Oak Point: 1884, arrived May 25; 1885, tirst seen, one, on May 19; is common and breeds hero (Small). Ossowa: Common; breeding; 1885, tirst seen, two, on May 15; next seen on May 17; became common on May 19 (Wagner). Portage la Prairie: Common summer resident; arrives about May 20; in 1884, first seen, May 27 (Nash). Carberry: Common sum. mer resident (Thompson). Very common in woods around Lake Manitoba (Macomn). Shell River: 1855, first seen, one male, on May 16; next seen, four, on May 18; is common here all summer and breeds ;Calcutt). Qu'Appelle: Common - sumuer resident; breeds; arrives May 18 (Guernsey).

On June 25, 1882, on the north bank of the eastern slough, I found a Baltimore Oriole's nest in an oak tree, abont 10 feet high. As I was climbing the tree the female bird flitted about, uttering a loud, harsh chatter; as she often came close to my heal I hal good opportunity of viewing her graceful form and rich yellow plumage, and I thonght her the most beantiful bird I had ever seen, until a moment later her splendid mate flashed into view on an adjoining bough, and stood there blazing in the sun. Ho was much less bold than his mate, and did not chatter in the same way, but uttered a loud "puhee" like a fragment of his song.

This nest was about 4 inches deep. It was formed of the onter bark of the Aselepias, and so thoroughly interwoven and "darned" that the fabric was like a thick warm felt. It was remarkably strong, too, and with a view to testing it in this particular I bronght it home with the branch that bore it, ancl, having hung to it a pail by a band across the upper surface, proceeded to ald weight. Fifteen pounds was gradually added without its showing any signs of breaking, but at the seventcenth the weight slipped to one side, and being thrown upon but one of the fastenings, broke it. I then procured another nest, an old one of the saue material, and triel it successively with 15, 20, 25, 27 pounds, and still it held together; 29 and 30 were reached without breakage, but at 31 it began to give, and after a fow seconds the weight tore through the fabric, without, however, injuring the fustenings at the top.

On Vetober 19 fonnd an old nest of an oriole down by the slough. It was woven of strips of Aselepias bark and suspencled from four or five twigs. I made a careful test of its strength and found that it bore

sou).

(Murr:

Apr

poplar

They sound

Apr

thonsa on whi songs

far-aw floeks

171. 
15 pounds weight without the least sign of breaking, but an additional 2 pounds, throwu carelessly on, tore it from its fistenings.

\section{Scolecophagus carolinus. Rusty Blackbird.}

Enormously abundant migrant. Pembiua (Smithsonian Institntion) (Blakiston). Very abundant at Mouse River, on the boundary, after the second week of September (Coues). Dufferin : Arrives before April 15 (Dawson). Morris: April 29, 1887 (Christy). Ossowa: 1885, first seen, one, on April 8; next seen on April 16; became common April 20 ; last seen, about twelve, on October 24 (Wagner). Very abundant duriug the spring migrations, and again from August to the middle of October ; arrive abont the 10th of $A$ pril; some of these birds may remain to breed in this locality, but I have not found them so engaged (Nash). Very abundant on Swan River in September, 1881 (Macouu). Carberry : Extremely abundant in the migration; Rat Portage: Uctober (Thompson). Severu House; Trout Lake Station, the most northerly species (Murray).

April 15, 1882: Snow still deep everywhere, but inelting fast. In the poplars along the slough side to-dlay was a large flock of Rusty Grackles. Thoy were singing together their loud, jingling, sluring notes, and the sound was like a chorus of innumerable sleigh bells.

April 21: The thousands of Grackles have been increased to tens of thonsinds. They blacken the fields and cloud the air. The bare trees on which they alight are foliated by them. Their incessant jingling songs drown the music of the Meadow Larks and produce a lreany, far-away effect, as of myriads of distant sleigh bells. Mixed with the tlocks of Rusty Grackles now are a few Red-winged Blackbirds.

171. Bcolecophagus cyanocephalus. Brower's Blackbird. Satin-birl. Blueheaded Blackbird.

Abundant snmmer resident. Pembina (Kennicott). Abnndantalong the boundary, from Pembina to the Reckies; breeding (Cones). Winnipeg: Summer resident; abunlant (Hine). Ossowa: Common; breeding (Napull). Carberry : A bundant summer resident; breeding. Big Boggy Creek: Common; breeding (Thompson). Portage la Prairie: These birds commit fearful deprelations in tho oat and wheat fields after the grain is ripe, particularly if grown near the woods or a marsh (Nash).

On June 8, 1882, O. T. found a grackle's nest on the newly harrowed ground in a field not more than 20 yards from a clump of willows. The eggs, five in number, were in a slight hollow in the ground, with. out a single straw or any pretence at lining. My brother sprang the bird and then ealled me. I did not see the birt rise, but a pair of grackles were flying about and noisily resented our interference, and as no other birls were near, I feel safe in the identification.

On June 21, while walking by the south slough, I came npon two grackles that were at great pains to inform me that their uest was elose 
at haud, and also that my presence was most unwelcome. I at once set about seeking the treasure house, and found my ablest assistants in the birds themselves, for, as little children playing at hicle and seek direct each other by crying " hot" or "cold," so these grackles gulded me, eeasing their clamor somewhat as I receded, and redoubling their onteries when I approached the site of their nest. In this way I soon founcl it. It was placed on the ground in the open, sheltered only by a few weeds; it was a bulky structure, composed chiefly of roots, but lined with hair. It contained three eggs of the grackles and one of a cowbird. I have never before heard of a cowbird intruding its fonndling on a species larger than itseif.

September 18, 1882: September is going fast now; in the early mornings the sky has a cold steel-blue look along ide horizon, and the elouds that come up are white aud lumpy looking. We are expeeting frost soon, for many signs announce that the fall is here and passiug quickly. Already the grackles are gathered in the immense flocks in which they migrate, and are even now moving sonthward. We thought them uumerons in the spring, but they seem to be ten times as plentiful now. The sound of their wings as they arise or fly overhead is like the noise of rushing breakers; it is not at all like thunder, as some have described it, lut resembles the rattling shr-a.a.ay of surf on the shingly bench. The murmur is so continnous as to suggest the roar of a waterfall, and, as in that, there is a beat in this, thus: shri-ri-ri-vir.ri, otc., makiug the resemblance still more perfect. Their loud crek-crek's also combine to form a great sound; it does not unite with noise of the wings, but remains sharp and separate on the vaster volume, just as the black dots and wriggles sometimes seen on their eggs remain separate and eontrasting with the purple mottlings, though oecupying the same ground.

This grackle is generally distributel throughont the Assiniboine Valley. It arrives and moves so constantly with the Rusty Grackle that it was but lately I learned to distinguish them, and my previous impression on the subject of their specitic distinction negatived the value of a number of observations.

The dozen of nests of this species whieh I have examined were all either on the ground or in low forks or saduled on logs, close to some pond, and were more or less eomposed of mul when elevated. I fonnd half a dozen nests around a single small lake on the Duck Mountain. The eggs are in color between those of the Rusty and Purple Grackles.

172. Quiscalus quiscula æneus. Bronzed Grackle. Crow Blackbird.

Abunclant sumner resident wherever there is both wood and water. Mbuudant at Pembina; breeding; Mouse River (Cones). Winnipeg: Summer resident; abundant (Hine). Red River Settlement (Gunu). Ossowa: Breeding (Wagner). Oak Point: 1884, arrived April 10; 1885, first seen, two, on April 16; next seen on April 18, when large

flocks e Very co Octobe seen in Nortliw Duck first sec mon; b oll Apr April 2 here arrives bird sp Winni] at Nor (Blakis

Oı $N$ grackle Rusties littlo $\mathrm{h}$ - was co As he allowec ance in assiduc liberty of pre of toor He wo he wor hawk, sangui am so 
at once fants in ad seek guided ig their I soon only by ots, but pne of a found-

o early and the ppecting passing ocks in d. We times as verhead uder, as isurf on gest the s, thus: t. Their ot unite e vaster on their ottlings,

ine Valkle that lous im. he value were all to some I found ountain. rackles. sird.

d water. ninipeg : (Gunn). pril 10; large

flocks came; is common and breeds here (Small). Portage la Prairie : Very common summer resident; arrives about April 15, departs early in Oetober, the first frost hard enongh to form ice driving them out; first seen in 1884, April 16 (Nash). Very abnudant abont ponds in the North west (Macom). Carberry: Common snmmer resident; breeding; Duck Monntains; common; breeding (Thompson). Dalton: 1889, first seen, four, on April 8; next seen, April 12, when it became com. mon ; breeds here (Youmans). Shell River : 1885, first seen, seventeen, on April 15; uext seen, a hundred, on April 22; became common on April 24; male and female in flock; common all summer and breeds here (Calentt). Qu'Appelle: Common summer resident; breets; arrives April 25 (Gnernsey). In September I found the Crow Blackbirt sparingly (along Nelson River) between Hudson's Bay and Lake Winnipeg; also westward, except abont the little cnltivated ground at Norway House and Cumberland, after which (October 4) are not seen (Blakiston).

On May 1, 1882, W. Brodio shot into one of the immense flocks of grackles that frequent the stubble field, and bronght down sixteen Rusties and one Bronze at a single diseharge. The Bronze was so little hurt, being slightly grized on the wing, that his death seutence - was commuted to imprisonment in a nail keg under strict surveillance. As he manifested a cheerful and intelligent disposition ho was soon allowed the adlitional privilege of unaking himself a veritable nuisance in every corner and department of the house, and so thoronghly and assilnonsly did he apply himself to take the fullest advantage of this liberty that every one but myself was thankful when, after a few days of pretended resignation, he took the first opportmuity of skipping out of doors for good. My observations on this birl were mneh as follows: He would eatany thing that was eatable, but preferred flesh. A mouse he would hold in his claws and devour exactly in the manner of a hawk, swallowing each mo:sel as it was torn off by his bill. This sanguinary taste, I fear, points to a nest-pilfering propensity that I am sorry to admit.

I never before saw a wild bird take so readily to eaptivity. Within two or three days he became quite at home iu the kitchen, and perfectly familiar with the place and purpose of the water pail. He had a cur:ons way of hanging lown warls from the rim when the water was low, so as to reach it, and he never failet to seareh for the pail whenever he desirel to drink. I often detected in the croaks and eries he uttered a peculiar, alıost hunau, timbre, that suggested tho possibility of his learning to articulato worls. From the first he exhibited a magnificent development of impudence and vanity. He wonld pose in the sun and admire the effeet of it on his really. splendid plumage, till one would suppose he thonght he was the Bird of Paradise itself, instead of merely n very distant rolative. Altogether, in spite of his troublesome disposition, his playful ways and general enteness made mo so foud of him that I was heartily sorry when poor Jack disappeared. 
173. Coccothraustes vespertinus. Hvening Grosbeak.

Common winter visitant; possibly nesting. Winnipeg: Tolerably common winter visitor (Hine). I have never seen this bird myself here during tho summer months, but have noticed them in the antumn, winter, and early spring at Selkirk and Big Island, on Lake Winnipeg; the lialf-breed who was with me at Big Island told me that they were at Selkirk all the year romnl (R. H. Hunter). Portage la Prairie: Abnndant winter visitor from Uetober 15 to abont May 16; Winnipeg, less common; Riding Monntaiı, in December (Nash). Shell River: 1885, seen Fobrnary 20 (Calcutt). Qu'Appelle: Common winter visitor; large flocks seen in February and March (Guorusey).

Mr. Hine tells mo that this bird is very abundant abont Winnipeg in the winter and spring. It is usnally seen in the groves of soft maple, on whose seeds it feeds. Its note is like that of the Pine Gros. beak, but shriller, and resembles the syllables "checpy-teet." He says it is known by the name of Sociable Grosbeak, as it is always seen either in pairs or in small flocks.

This bird is an abundant winter visitor at Portage la Prairio, whore the first generally appear about the 15th of Oetober. From that date thoy continually inerease in numbers until tho 1st of December, when they reach the maximum. Whilst here they frequont the Northwest: Maplo or Box Aliler, feeting on its seeds, and seldom visit the gromul, except in spring, when they will sometimes crowd thickly on a lare spot, appurently seeking small gravel for cligestivo purposes.

During the winter they are usually to be seen in small parties, not exceeding six or eight in number, but early in April they eongregate into large flocks, in which the males proponderate; they are then restless, frequenty rising from the tops of the trees and flying abont high in the air in cireles over their hannts. They romain here until abont May 16, when they all disappear together.

In viow of the fuet that this bird's nest has hover been fonni, it may be worth noting that the Pine Grosbeak, its invariable associate in the winter, whose nest and ?reeding place is known, leaves here about the end of March, whilst the Evening Grusbeak ronains in its winter quarters six weeks la ier, from which I wonld infer that it shonld not go so far from its winter hamnts to " . . is does the Pine Grosbeak.

On the 13th Decomber, 1884, I saw a flock of these birls in the Riding Mountain, and observed them every day after that nutil the 20th, when I left. I did not find them nearly so common on the Red Rivor as at Portage la Prairie. (Nash, in MSS.)

\section{Pinicola enucleator. Pine Grosbeak.}

Somewhat common winter visitant; possibly nesting in the northern woods of apruce. Winnipeg: Winter visitor; tolerably common (Hine). Red River Valley : Rare and accilental near Wiunipeg; plentiful in spruce east and north of Winnipeg (Hunter). Swaup Island: 1885; rare; migrant; seven observed November 6 ; last seen November 7 (Plunkett). The Pine Grosbeak was frequently seen on the Chnrehill River in the end of July, showing that it probably breeds in this region (Bell, 1880). Portage la Prairie: 1890; common winter visitor; arrives about the 1st of November, departs about the middle of March; feeds largely on the sceds of prairie plants projecting above the snow; ob.

served in

lake, 188

Branilon :

Winter $\mathrm{v}$

Hocks see

On Nor

beak whi 9.1 , exten lird was

On Der ing singl: of the po

Decem! female, a

Summe latter par summer 1 common ber 15; c pluinage IIouse: J May, 182 fall at $P$ one male passing I

On Ma liverywh the rump stained a spruce b in the $f$ son). II the pine ter and snow an there is favorite 
servel in the Rilling Mountains, December, 1884 (Nash). Red Deer Lake, 1881 (Macoun). Carberry: Common wiuter visitor ('Thompsou). I3ranlon: January 24, 1883, aud February 22 (Wood). Shell River: Winter visitor (Calcutt). Qn'Appelle: Common winter visitor ; large tocks seen all winter (Guerusey). Severn House (Murray).

On November 9, 1832, among the eastern sand hills I shot a Pine Grosbeak which hal perched on the top of a tall spruce tree; female; length 9., extent 14; gizzaril filled with what I took for spruce seeds. The lird was nttering a loud whistle from time to time.

On December 6, at the spruce bue!., saw several Pine Grosbenks fly. ing singly or in twos and threes; they seemed to be feeding on the tops of the poplars. This was about sunset.

December 7 , at the spruce bush in the morning, I shot a Pine Grosbeak, female, and saw a fine red male.

\section{Carpodacus purpureus. Pnrplo Finch.}

Summer resident; in small numbers on Turtle Mountain luring the latter part of July; donbtless breels (Cones). Winnipeg : "Pine Finch," summer resident; tolerably common (Hine). Portage la Prairie: 1890; common summer resilent; arrives abont $A$ pril 20, lleparts about Ucto. her 15; contrary to my experience in Ontario, I find that here the full plunnaged crimson males are the first to arrive (Nash). Swan Lake Honse: July 11, 1881; doubtless breeding (Macoun). Carlton House: May, 1827 (Richardson). Carberry: Tolerably common in spring; in fall at Portage la Prainio (Thompson). Sliell River: 1885, first seen, one male, on $\Lambda$ pril 30 ; next seen, fonr, on June 3 ; a transient visitor, passing north and not remaining any time or breeding (Ualcutt).

On May 14, 1883, I shot an adult male Purple Finch in full song. Everywhere tinged with crimson except the belly, which was white, and the rump. which was yellow; even the gizzard and all its conten is were stainel a rich crimson. It had been feeding on poplar catkins.

176. Ioxia curvirostra minor. Ameriean Crossbill. Red Crossbill.

Winter visitant; possibly also breeding. Winnipeg: Tolerably com. mon (Hine). Red River Valley: Permanent resident; abundant in any spruce bush (Hunter). Saw one female that was taken at Gladstone in the fall of 1885 (Nash, 1890). Carberry: Winter visitant (Thomp. son). In Minnesota very abunclant; breeding; I never saw it out of the pineries (Tripue).

In Manitoba I failed to detect its presence excepting during the winter and spring. It generally appears in the Carberry woods with the snow and thenceforth thronghout the winter; it is common wherever there is plenty of spruce and tamarac, for the seeus of these are its favorite food. 
Winter visitant; possibly resilent and breeding. Winnipeg: Tolera. bly common (Hine). Oarberry: Wintel visitor (Thompson). Severn House and Tront Iake Station (Murray).

On December 6, 1832, at the spruee bush, $35^{\circ}$ below zero, shot three White-wingel Crossbills ont of small floek thit was feeding on the cones of $n$ tall suruce. These wero all males.

178. Acanthis hormemanil exilipes. Hoary Recl-poll.

Migrant and winter visitant. Winnipeg: Rare; winter visitors (Ilint). Specimens taken at Carberry in the early winter from a flock of the Acanthis linuria (Thompson). Linota borealis, Severn House (Murray).

\section{Acanthis linaria. Red-}

Abundant fall and winter visitunt. Winnipeg: Tolerably common in the migration (IIine). Portago la Prairie: Abundant winter resi. dent arrives about Oetober 20; departs abont May 1; observed in the Riding Mountuins, December, 1884 (Nash). Carberry: A bumlant in the fall migration (Thompsou). Shell River: Winter visitor (Calentt). Qu'Appello : Common; arrives $\Lambda$ pril 1 (Guernsey).

On Outoher 25, 1882, saw a conple of red-polls ubont the harnyarl. They wero feeding on the cottony crests of the solidagos.

On November 3, shot three red.polls; one was a female, crimson on poll only; gizzarl tilled with various sinall seels. Theso appear to be Acanthis exilipes.

On November 6, „ tlock of redl-polls applenred und were feeling on the weeds near tho liarnyard.

180. Spinus tristis. Amoricnu Achlfinch. Will Canary.

Common summer resident. Notel only at Pembina (Cones), Will. nipeg: Summer resilent mbunlant (Hines). Oak Point: 1884, „r. rived; May 20 (Small). Portage la l'rnirio : 1890, arrives abont May 25 ; common summer resilent; departs about the ond of Neptember (Nush). Curberry: Common summer resident; nlundnut in Angust aul September (Thompson). Shell River: 1885, ftrst seen, one mule, on Mny 24; next seen, two, June 3 ; is common all smmmer; brechs (Culentt). Qu'Appelle: 'Tolernbly common ; summer resident. Arrives May 24 ; breeds ((thernsey).

September 9, 1884. The goldfluehes are now going southward in large flocks. For tho last month they luve lod a roviug life in buncls of both sexes; especinlly lirequenting fleguarils nul old breakings, where there is usunlly a luxuriunt growth of pruirie sumflowers (daillardin), whose seel is a fiuvorite fool.

In Manituba I have not noted the hirel loefore the encl of May. In this coun oll the 8 (G.pulch heavier $\mathbf{t}$

About sexes an the 10th

An irr Red Riv saw two 1886 (No mon (Th migrates

()n ID swoop of and whe

182

Very : Very al, liver $\mathbb{8}$ seen, $t w$ commou oll Octu March 2 Lake: 1 winter $\mathrm{r}$ middle hirds w the pro coun).

its long ter visi Lake o (Miurr) time de but the

In N hartlih snow f timnes mung wentlie 
this country it finds neither thistles nor orchards, so it feels largely on the seet of the prairie suntlower (Rudbeckia hirta) and Gaillardia ( $(r . p u l c h e l l a)$, and nests in the low poplars and oakson the edges of the heavier timber.

Abont the enc of Angust they gather into roving bands of both sexes anil feast on the now abundant supply of sunflower seed; abont the 10th of September they disappear.

\section{Spinus pinus. Pino Siskin. Pine Linnet.}

An irregular migrant. Winnipeg: During June it is fount along the Red River in hundreds (Hine). 1890 : Rare and irregular visitant; I. saw two or three Hocks near the Red River in September and Oetober, 1886 (Nash). Carberry : Irregular spring and fall migrant; not eommon (Thompson). In Minnesota observed in great numbers in the fall; migrates sonth in winter (Trippe).

(n Deeember 5, 1883, at spruce bush, saw a large tlock of small birls swoop on the top of a bireh tree, then an instant later sw eep oft again and wheel off twittering into the woots. I took them for P'ine Linnets.

182. Plectrophi,nax nivalis. Snow-llake. Snow Bunting. Snowbird.

Very abundant early spring ; fill and winter resillents. Winnipeg : Very abmulant wiuter visitant; seen as late as June 10 (Hine). Reel liver Settlement in winter (Blakiston). Swampy Islaml : 1835, first seen, two, on $\Lambda$ pril 4; next seen $\Lambda$ pril 13; last seen May 1 ; is tolerably commou in fill and spring; (loes not breel; flrst seen in fall, twenty, on October 12; nfter this it becnme common; 1886, first seen, eight, on March 29; bulk arrivet $\Lambda$ pril \&; last seen, $\Lambda$ pril 18 (l'lunkett). Shell Lake: 1885; winter visitor (Calentt). Portngo la Prairio: $\Lambda$ bunclant winter resilent; arrives abont October 10; ileparts usually about the midille of April (Nash). Manitola Honse, 18th Oetober, 18is, snow. hirds were flying abont the post in large flocks (Hind). Abmudant on the prairies hetween Braudion and Fort Etlice in October, 1881 (Macoun). Carberry : Alundint from November 1 to April 30, or usually as long as there is any snow (Thompson). Qu'Appelle: Common win. ter visitor; leaves about May 10 (Gmernsey). Severn Honse, Tront Lake Stution: Only goes to tho sonth when the snow becomes leep (Murriny).

Dnuphin Jake, Oetober 7, 1858, snowbirils were seen for the flrst time during the afternoon. 'They cme abont our eamp in large Hocks, lint tbey did not uppenr to have quite assumed their wintei dress.

In Manitoba, perhups more than in any of our southern provinces, the hardihool of this most hardy birl may lost be seen. As soon as the snow fills the snowbird appears in force, and nll winter long he eontimnes to twitter eheerily abont the cheerless ontbuildings and fornge mong the litter of the barnyardn. The snow conses deeper and the wenther gets colder, till the thermometer seems settleil to sleop awny 
down among the 20's below zero, and still the merry, rollicking snow. birds roost on the barn and twitter and enjoy life ; laugh and grow fit they surely do. Many that $I$ have taken at this season are like balls of butter, and the clouds of blinding, biting, stinging snow that career over the desolate plains seem no more to them than a summer zephyr. The winter aspect of the prairie is dreary enongh to onr eyes. Bnt wien the winter storm-the biizzard-arises, burying the land in snowdrifts and destroying life with a gale of ind chilled to 50 or 60 degrees below zero, it may well be wondered that the hardiest of animals are left alive, so terrible is the power of this overwhelming torrent of snow.

Then it may be asked, when the blizzard is over, was the snowbirl out in all this He was certainly not in ; anl yet ho was in, for his ell. emy is his friend. The deally snow savel him alive from itself; he was not killed, but buried. Ho had indeed descencled into the grave to save his life, for like several other birls tlıat brave the northern winter, he has learned to crouch cluring a snowstorm in some recess or hollow, and his warm, protecting counterpane is the snow.

It is said that no birl goes fartlier north than the Snow Bunting. With him, if with any, is the secret of the Pole. In that desolate land where higher beings can not live, the young snowbird is reared in peace, like a frail flower springing up in the very cave of leath. The sentiment of the strange construction is fully illustrated by a sight recorled on Sonthampton Island, by Oaptain Lyons, the explorer. Cold and hun. ger had swept away a tribe of Esquimaux; their bodies lay aoout what was once a village; on the shore, half buired by the sand, was the the body of a chlld, und on its breast a snowbird had built its nest and was rearing its young.

Thede abundant winter hirisarrive at Portage la Prairie abont Ootober 10; depart usually abont tho midule of April. Their movenents being influenced grently ly the weatluer, so long as tho gronul is eovered with snow they will romain, bit as soon as the baro gromul is vislble thoy dinaplooar.

A fow pairs uny remnin to breed with $\mathrm{nw}$, for on the 234 of $: " n y, 1884$, I surprised a puir of them drinking ont of a tub in my gardon. The day was very warm, nnd nfier they flow on the fonce I noticed that they soemenl oppressed with the liont; their beaks were hekl open ns ono sometimes soes onr common hiris holding ?heirs on hot

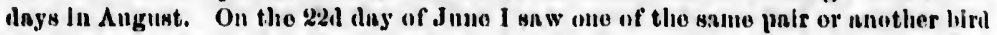
ulso in my garden ragerly lanting for food, but unfortunately I lost sight of it wills. ont tracing it to its nest, if it had one. (Nash, in MSS.)

\section{Caloardus lapponious. Lapland Longepur.}

Vory alonndant spring and fall migrnnt wherever there is prairie or cleared conntry. Monse River, October (Cones). Dnflerin: Arrive be. fore April 15 (Bnwson). Winnipeg: Abundnnt migrant (Hine). Abun. dlunt at lint Portnge, October, 1886 ('T'hompson). Portage lin Prairie: Common in the spring; aometimes ubundn..t in untmmn (Nash). Very common on the plnin at Fort Peily, and on the roml between fort Ellice mnd Brandon, lnring September nul Ootober (Maconn). Car.

berry : Lno migration ; (Thompson Lake Static On May River we in of thousan the flood th as for as th dim distanı seemed to 1 settle on $\mathrm{tl}$ while the I clianges of onward me preponder: the Black-1 searcely re

Septemb great $111 \mathrm{~m}$ their exqui my feet, ut plainly, su these long up they fle (1) the sout fer lowe.

May 15, in the air sancl voice newly sow pivot, arou anchor the drop the o whistling rise in $\mathrm{a}$ whistling. and in sor

In tho I the sharlo keeperlgi and no do

May 16 bircl that white on May 17 
king snow. ind grow fit like balls of a career over ephyr. The

But wiien 1 snowdrifts grees below re left alive, ow.

le sllowbirl 11, for his ell. n itself; lse the grave to hern winter, ss or bollow,

nting. With land where I peace, like o sentiment recorded on Id and hun. aoout what ind, was the its nest and

ber 10; depart ed greatly ly remuin, but as

34, I surprised 'mrm, nud affer he lient ; their ?'IBirs on liot $r$ inotlier lirirl ght of it with.

is prairio or Arrive be. ne). Alum. la Prairie: ash). Very twoen Fort oili). Car. berry: Enornously abundant in tho spring, and less so in the fall migration; plains sonth of the Souris River; abundant in spring (Thompson). Cumberland Honse, late in May (Richardson). Tront Lake Station and Severn House (Murray).

On May 13, 1882, while crossing tho Barren Plain south of the Souris kiver we met with immense !orles of longspurs, thousands and tens of thousands of them; flock after flock, or rather wave after wave, in the flood that seemed never entirely to cense passing over. Un all sides, as far as the oye conld reach, they were to be seon strotehing away into dim distance, like swarms of bees or gnats. Wach wave of tho flood seemed to tly on low over the plains for a short distance, and then settle on the ground to rin. abont and forage among the bunch grass while the next wave passed overhead. 13ut, in all their flights and changes of front and pace, one thing was noticeable, they kept a steady onward movement to the north. They are ehiefly of two kinds, the preponderating speeies, the Lap Longspurs, and the next in numbers, tho Black-brenstel or $C$. ornatus, and tho last tho Painted Longspurs, scarcely represented at all.

September 6, 1883. The fall flowor, the gentian, has just come out in great numbers. As I crossed to a part of the prairio where I might seo their exquisite blue in perfection, a small flock of longspurs rose from my feet, uttering a doleful whistle. Two sal signs these; both say plainly, summer is gone aud fall is short and passing away. Even now these longspurs were tying from the firost, and as often as I put them up they thew, not haphazard, but before me, or over my head, always to the sonth; every move must help them in their jouruey to thoir win. ter home.

May 15, 1884: Tho Lap Longspurs are hero again in thousands. High in the air they fly in long straggling flocks, all singing together, athonsand voices, a tornado of whistling. Orer the prairie they go, on to the uewly sown fields, and here the thock Iropis a feeler, a sort of a:ıchor or pivot, aronint which the whole body swings; then lifting ngain their anchor they wheel about and perform two or three evolutions, ugain Irop the mnchor and at length form " dense close colnmn, and ceasing whistling they swoop down to the field to fornge. When sprung they rise in a dense buiy, but at once spread ont and begin tho merry whistling. It ls a peculiar sound of multitudinons melody, but not loud, and in some respects iike the sleigh-bell chorus of the blackbird.

In the heat of the day these birls may be seen sitting in long rows in the shindow of ench post in the fenco; as the sun moves nround they keepelging aloug to aroid his rays. They do not seem to liko the hent anil no doubt will soon go.

May 16: Very wurm, 870 in the shale. Saw on the prairio a strunge bird that might lare been a female longspur, excepting that it lial no white on the tnil that I could see.

May 17: Buormuas tlocks of loagsumers are still to be seen mbout tho 
newly sown fields. The gizzards of those I opened were full of oats, wheat, buck wheat, and grass seed. There are two species, the Lap and the Painted Longspurs. Grangers, the farmors here eall them indis. criminately. The merry ehee-chupping of the Laps, and the sweet singing of the richly colored Painted Lougspurs make a continuous melody, like the spring jiugling of blackbirds, but with more of the tone of bobolinks. Both sing on the ground. None of the specimens taken showed any anatomical signs of sexual exeitement, so that they probably go much further north to breed.

About the midlle of May every year the Lap Longspur comes to this country, associated with the ehestnut-collared Painted Buntings, in enor. mons flocks, coming in May, just after the erops are in. They lo a grent cleal of damage, picking up first tho seed that is exposed and afterwarcls teariug it up when it begins to spront. A large number that I shot about this time had their gizzards full of oats, wheat, hayseed, and buck wheat.

When in the field. hey have a curious habit of squatting just behind some clod, and as th apuer colors are nearly matched to tho soil, they are not easily obser ed, nor will thoy move until sou are within a few fret; they then run a fow fiet and squat again, unless closely followed so that they must fly.

When in the air they move in grent straggling flocks, all whistling togethor, so there is a perfect toruado of song. Merrily thoy fly along to the new-sown fields; then tho ragged thock drops a feeler, an anchor or a pivot round which the whole army wheels, mind after performing two or three evolutions in close column, fiually cease whisuling and swoop onto the field to forage. Whon "sprung" they rise in a dense body, but soon at once spreal ont and begin the merry jingling, a sound of multitudinous melody somewhat like the noise of Blackbirde.

In the heat of the day (for we often have it over $80^{\circ} \mathrm{F}$. during May, shucle register) they may be seen sitting in the shadows of the fence posts, in each sbudow a long gronp jnst the size of the post, and as the shadow moves they will elge romol to avoid the sun.

As the middle of May passes the jiugling music becomes louder and more vigorous. The effect of a large bolly of longspurs singing is somewhat similur to that of a small body of bobolinks. They (pictus and lapponions) now sing both in the atr and on the ground. The song of the lapponiens is like "chee.chuppy chuppy" repented with short in tervals; the pictus has a more protentions song The latter went north ubout the 20th of Mny, in 1884; the formor remained until about tho 1st of June.

They retire to the far northwest to breed, but return agnin during the last week of September. They remain on the stublule flelds for abont two weeks before migrating sonthwarl. Their numbers now are much less than in the spring migration, contrary to what might be expectod. 
full of oats the Lap and them indis.

d the sireet continuous more of the e specimens so that they

comes to this ings, in enor. ey do a grent l afterwards that I shot ayseed, and just behind ho soil, they rithin a few followed so

fll whistling bey fly alonir $r$, un auchor ' performing hiouling and e in a dense ing, n sounl irde. luring May, of the fence , and as the

loucler and siuging is hoy (pictus sund. The with short : went north bout tho 1st

during the r nbout two b much less pectod.
184. Calcarius pictus. Smith's Longspur. Paintel Longspur.

Abundant spring, but rare fall migrant; ono in Smithsonian Institution from Pembina, September (Kennicott). Monse River (Coues). Carberry : Extremely abundant; migrant; staying for about two weeks in spring, and returning for a few days in the fall (Thompson). Severn House : Seems scarcer than the others; Sir John Richardson mentious that he had only obtained one specimen; three have been sent to me (Murray).

May 13, 1882, on the plains south of the Souris River, a few Painted longspurs were observed with tho immense flock of Lap Lougspurs that are now passing northward.

May 17, 1884, Carberry: The Painted Longspurs are here now in enormous numbers, nceompanying the Lap Longspurs. They sing a sweet continuous song while perching on a clod. To.day I went out to collect a tew out of the vast flocks that are daily about the newly sown fields; northwest wind was blowing and I approaehed from the east, but I could not detect a bird on the ground, although I was springing them from my very feet at each step. They have a habit of squatting closely when approached, then springing up they fly oft' with undulating flight ; and as during this it is not ensy to collect the bird, I got no specimens mutil it occurred to me to go aroumd and approach the flock from the west. As soon as I dich so tho whole field seemed alive with the longspurs; their gay bosoms were thickly speckling the lark earth for acres, and I ha ! no difliculty in getting as many as I needed.

Although in full song I could detect uo signs of amatory passion in these birds, so that no doubt they go very much farther north to breed.

185. Calcarius oruatus. Chestnut-collared Longspmr. Black-breasted Longspur.

Common sum mer resident; local in distribution, many pairs some. times affecting a limited area of dry prairie, while again for miles no more of the species ure to be seen. Wonderfully abumlant; breeding uloug the boundary from 20 miles west of Pembina Mountain to Mour. tana (Cones). Winnipeg: Summer resident; abundant (Hine). Shoal Lake, May 16, 1887 (Christy). Portnge la Prairle: 1890, a colony ubout 2 miles north of here (Nash). Breeding in numbers on the Souris Plain, between Brandon and the Brindon Hills und sontl westerly, late in June and early in July, 1881 (Macouu). Great,numbers south of the Souris (o)I the Brandon Trail, a colony at Chuter, and auother in tho Big Plain near Boggy Oreok (Thompson).

May 15. Uamp 30 miles south of the Souris, over the same monoto. nous rolling prairle, in succession of ridges with duck.poncls in the hol. lows between. The Black-broasted Longspurs are still very numerous, though mueh less so thum they were two days ngo, und nre now mostly seen in pairs. The males are frequently seen to spreid their pretty black and white wings and tuils and rise in the air about 10 feet, where they 
sing sweetly for a minute or so; then, having let off the ebullition of feeling that prompted the action, they dirop to the ground to chase their mates, or to resume the more humble vocation of foraging, mouse-like, anong the bunch grass. There scemed to be a vast colony of them breeding at this particnlar place, but after moving a few miles further on none at all were to be scen.

On June 's, 18s4, on a barren ridge of the rolling prairie beireen Bog. gy Creek and Petrel, I found a colony of over a dozen pairs of Blackbreasted Longspurs. I did not succeed in fiuling the nest, as my visit to the place was merely in passing through " per cart," but I was able to make a number of observations on their song and habits. I fonnd them rather slıy of allowing approach, but quite inclisposed to cease whistling ou aecount of the intrusion. I was surprised to see them frequently pereh ou low bushes and sing there, also on the gronnd; so that some ecstatic singer would perhaps start his song as he squatted on terra firma, then spriug up, singiug in the air, and finish the perform. ance on some willow bush. The song was somewhat like that of a bay. wing, but with a more mellow warble and withont the slurred notes. The accentuation I noted down from the bird's dictation, as foltows:

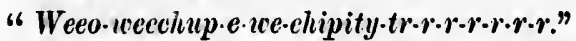

Specimens shot had their gizzards full of grass seed and small insects of all sorts, but chiefly coleoptera.

When sprung they had a habit of rising abruptly and flying with deep undulations for abont 100 yards, when they wonld pitch down again. On going to the place they would be found to have run some distance, and would again spring from a totally unoxpecterl quarter.

186. Poocæetes gramineus confinis. Western Vesper Sparrow. Baywing.

Very abundant summer resident on the prairies. Breeds in abundance from Pembina westward along tho boundary to the Rockies (Coues). A specimen from Rel River Settlement in Suithsonian Institntion(Blakiston). Winnipeg: Common summer resident (Hine). I'ortage la I'rairie: Common summor resilent; arrives about May 10 (Nash). Common on the prairies, from Brandon westward (Macoun). Carberry : A bundaut summer resilent; breeling also along all the trails in the prairie region towards Brandon and Fort Ellice. Shell River: Breeding (Thompson). Shell River: 1885, first seen, two, on April 29; is common all summer, and breeds here (Oaleutt).

May 11, 1882: Traveling to day on the old Brandon Truil. As we follow its winlings over the sterile pritio about Fairviow, large numberis of Vesper Sparrows are to be seen, rumning und hopping in and ont annong the tults of bunch griss, or flitting just ahend of the horses, which they seem to think are pursuing them. This is the first time I huve observed them, but they are in extraordinary numbers here.

On May 9, 1883, shot aVesper Sparrow, singing nt lusk; a male; leugth $6 \frac{6}{4}$, extent 11 ; gizzard full of grass. In tho evening, after 
ellition of feel. o chase their g, mouse-like, lony of them miles further

betireen Bog. airs of Black. t, as my visit ut I was able its. I fonul osed to cease see them fre. ound; so that squatted oll the perfor'm. liat of a bay. lurred notes. u, as follows:

and small in.

d flying with 1 piteh down ive riti some ctedl quarter.

• Baywing.

in abundance skies (Coues). itution (Blak. rtage la Prai3h). Common ierry : A bunII the prairie r: Breeding ; is common

ruil. $\Lambda$ s we , large num. pping in and it the liorses, o first time I rs liere.

sk; a male; ening, after dusk, a strange small sparrow ran aloug the ground before we, nttering a long twittering song in a quiet, cheerful way. I expeeted a discovery, but found it was only my old friend the baywing. I subsequently heard this effusion a number of times; it is like a soft continuous whispering of extracts from his various other musical performances. It was a male; length 64 , extent 11 ; gizzard full of graill.

On July 31, 1883, at Humphrey's Lake with M. O., wo noted a small bird that rose in the air singing a song like that of the English Lark, but less powerful. It sang and soared to a height of abont 40 feet, then sank again to the grass. After an eager pursuit it was secured and proved to be ouly a Vesper Sparrow.

On August 4,1884, heard a sparrow making a continuous screeching noise. It proved a baywing. In its bill was a grasshopper, and its gizzard was full of inseets. Three times this week have I heard the bay'wing singing its air song from aloft. These are the only occasions noted this year, and now the species is not singing its ordinary soug it all. Last year, as near as I remember, it was the samely.

Like its eastern relative this bird has a habit of running and flying by turns on the path, or a few feet before one. I have watched the conceited little creature when it chanced to alight on the trail, just in front of a train of over a hundred emigrant wagous, that, with a great herl of cattle and a rabble of boys and dogs, under guidance of noisy drivers and monnted outriders, presented a most formidable array half a mile in length, and the little baywing kept hop hopping along in front and watching back over his shoulder; or if the leader approached him too closely, he would take a short flight and continue on the trail hopping, and seem all along to say "Oatch me if you can, you folks; you are following hard and I am much amused." Then when at last he left the trail aud the crowd passed on, he seemed to congratulate himself on having outwitted them so cunuingly; or it may possibly have heen that he thought he was the leader of the whole train, for I have also seen him when the train turned off at forks tlit across the narrow point of land and again resume his task of leadership, much after the lashion of modern newspapers and politicians that are supposed to be the leaders of public opinion.

Another peculiwity of the sprecies is its fonduess for a dust bath. It will squirm and rustlo its plunnage and splash about in a dust heap for lialf au hour at a time, evidently e" ioying it hugely. On a small sandy spot by the honse door 1 used duily to see from one to six baywings enjoying their dry wasl, but rery rarely any other species.

In sone of its habits it presents $n$ consillerable difference to the eastern bird, being in my opinion a much more aceomplisliel songster, althongh superior opportunities for stulying this hirl way buve influ. enced my preference for its music.

During the months of July and Angust he censes his usual vesper scug, und vents his foelings in il loul, wild, lurk-like chant, which is Proc. N. M. 90-38 
poured forth as the birll rises high in the air. An English iend, on tirst hearing it exclaimel that it was the voice of a real skylark, but it proverl shorter and weaker. 'The bird begins to sing as he leaves the puririe, and sings and soars till he has reached a 'weight of 50 or 60 feet, when he again retnrns to earth.

This air suag is not hearl nearly as fregutently as the common pereh. ing song is in its proper season, nor have I heard both at the atme time of year. The perching song alone is heard during May and June, and again after the fall molt there is a renewal of the spring chintings-inl aftermath of song-for the bird ceises his souring lay and once more sings for the setting of the sun.

'This has an interesting bearing on the theory that many species often becone perfores air singers on betaking themsolves to prairie life.

But the s'mg that this species utters late in the day is its swoetest if not its supreme effort, at the time when the rediening sun is near. ing the horizon when, as the prairie tiumers say, it casts no shadow; when, in reality, the gronul is all in shade of the low ridges to the west. A bird on the prairie is in that shadow, but on springing up in the air the ruddy glow labls on him as he faces the setting sun ancl renews the song he sing for his rising. So springs and sings the Meadow-lark and many other gromul birls, and having vented their feelings in this last good-night, sink down into tho night which is alrealy on the ground. Then, as the sky larkens, the eastern colors become those of the west, ant the oast grows somber, the general acelamation dies away, but the Baywinged Bunting sings on eheerily as ever, aud is commonly left to sing alone in the gloaming lond as in tha daytime, but seeming twice as loud. The peaceful notes are poured forth till the whole proirie seems lul od by the sweotness of the struin. This is the vesper song-this is the Vesper Birl.

The little baywing (Poncretes gramineus) is one of the most familiar of prairie birls, and nightly siugs a subined kind of vesper song as the sun groes dows. Its most notable peenlinrity, lowever, is its babit of flitting along a trail or pathway in front of an mivinciug wagon or person, ulightiug every few yards As it is but comparntively recent that thero hitve been any human trails over the prairies, it seems probable that this procesding is a relie of a habit acpuired by the bird of thitting before the buflaloes along tho paths malo by thoso animnls. (Christy.)

187. Ammodramus sandwichensis alaudinus. Western Savanna Sparrow.

Abundant summer resident on the prairies. Breeds in profusion from Pembina westwarl, ulong the boundary to the Rockies (Cones). One from Red River Settlement in Smithsonian Institution (Blakiston). Winnijeg: Summer resident; abmudant (Hine). Portage la Prairie: Common summer resident (Naslı). Red I. :er River and Manitoba House (Macomu). Curberry: Abundunt nu ımer resident; breeding in all pruiries near Rupid City, nenr Bartle, Silver Oreek, Rnt Portage, Oetober ('Thompson).

On June 18, 1882, within a few feot of a straw stack in the barnyard,

where 1 nicst of : contain of horse

June

liar sim sparrow grassy 1 birds in Silvanu sollg is tship-e-s

Soon ont the I that chi that of with th. e.tship.e untiriug seem to

This ever ser

Abux wherev doubtld Pembin Finger and Sh Mount erowII Savan low fle Where promi its per lered that Anotl t.r.r.r. 
i(ind, OII kylark, but 3 leaves tho of 50 or 60

mon poreh. the name y aud Jume, ing cliant. ugr lay and

pecies often rie lifo.

ts swoetest siln is near. no sharlow; dges to the ringing $\mathbf{1}$ ug sizn and al sings the venteal their lit which is steru colol's the genoral II cheerily as nd as in tha are poured f the strain.

iliar of prairı os down. Its or patleway in As it is but he prairies, it ho bird of titisty.)

1a Sparrow.

ofusion from Oues). One (Blakiston). la Prairie: I Mimitoba breeding in int Portage,

10 bar'nyard, where loorses and cattie are continually running about, I found the nest of a Savanua Sparrow, protected only by a tuft of prairie grass. It contained five eggs, and was composed of grass with a meager lining of horsehair, the whole heing slightly sunk in the grounl.

June 29, Rapid lity: All this spring I lave been puzzled by a peeuliar simple little song that was uttered by a small insignificant-looking sparrow, which usually perched on the top of a low bush in a dry grassy locality. This afternoon I succeeded in shooting one of these birds in the very act, and was somewhat surprisecl to find that it was a Savanna Sparrow, a birl that I was other'wise very familial with. The song is realily suggested in my mind by the phrase "tship c.tship.etship.e-scree-tship."

Soon after arriving it may be seen on nearly cvery little willow bush on the Big Plain, repeating its short ditty, with the simple earnestuess that characterizes the Serub Sparrows. Its voice is much sweeter than that of the Shattuek Bunting (Spizella pallida), but it must needs finish with the inevitable "buzz." The song is shaped somewhat like "tship. e-tship.e-tship-e-scree-tship." This is uttered for hours together with nutiring diligeesee, and yet withal a lack of improvement that would seem to explode the old adage, "Practio", makes perfect."

This bird is renarkably shy, even in places where man is scarcely ever seenl.

\section{Ammodramus bairdal. Bairl's Sparrow.}

Abundant summer resident thronghout the Assiniboine Valley, wherever there are alkaine flats. One of the commonest birrls, and doubtless breeding along the houndary on the pritiries westwarl of Pembina Mountain to Mouse liver (Coues). Carberry, very rare; Fingerboard, rare; Shoal Lake, west, abundant; also at Birtle and Shell River ('Thompson). A supposed specimen obtained at Moose Mountain, July 3, 1880 (Mueoun).

On June 4, 1884, near Shoal Lake, west, shot a number of Bairl's Buntings. They do not answer to Cones's description (1 Key). The crown is suffused with dull orange. Its song is very like that of a Savanna Sparrow. In many parts of the prairies west of Birtle there are low flut alkaline stretehes sparsely covered with loug wiry grass. Wherever the land is of this charieter Batrd's Bunting is sure to be a prominent if not the prevailing species. It is now in full song, and its peculiar notes are to be hearl on all sides. The song may be rendered trick-e-trick-e-trik-eeeee-chiky-le-roit, with a peculiar utteran'se that at once distinguishes it from the song of Savanna sparrows. Another type of soug with this species is like trick.e trick.e.trike e $t \cdot r \cdot r \cdot r \cdot r \cdot r \cdot r \cdot r \cdot r \cdot r$.

Jume 22, Shell River country : Here the dry alkali bottoms are more frequent, and the bunting is numerous in proportion.

June 24, Shoal Inake: Baird's Sparrow is common about hore, though 
less so than at Birtle. On the Big Plain where there aro no alkaline flats; I have noted it but onco or twice. The general habits of this bird are much like those of the Savanna Sparrow. While singing it is usunlly perched ou some tuft of grass, each foot grasping a number of stalks to furnish support. When discoverel, it thits low over the flat and llrops into the grass. A number of the specimons taken were rather larger than the measurements commonly given.

189. Ammodramus lecontel. Leconte's Sparrow.

Abundant summer resident of willow bottom-lands in the Assiniboine houndary near Monse River (Cones). Near Winnipeg: "Sharptailed finch;" summer resident; tolerably common (Hino). Carberry : Abuudant snmmer resident; breeding in willow slonghs and grassy flats ; Fingerboard; West slope of Duck Mountain, abundant; breeding ('Thompson). Portage la Prairie : Rare summer resident in the large grass marshes near Portage la Prairio; may perhaps occur in larger numbers than is supposed, as it skulks in rank herbage and is diffienlt to flush, even with good spaniels (Nash).

In the afternoon of $J$ une 26,1882 , while riding after the cattle through the scrubby bottom land that skirts the eastern slough, I started a small sparrow from its nest. I dismounted and almost immediately foumd it; it was by a willow bush, and althongh apparently on the ground it was raised 6 inches or more above the wet by a matted tangle of twigs and grass on which it was placed. It was composed entirely of fine grass, and eontained three eggs. The old bird hurried with rustling flight iuto the willow thicket and continued flitting about or threading the mazes of the copse, and uttering from time to time their peculiar and characteristic "tweete !" which was of that ventriloquial ambiguiiy that makes it difficult to place unless the bircl is in sight. I had no gun, and knew I would not again be in that region for weeks, so I took the nest and eggs, not knowing the importance of the fincl. One of the eggs is $\frac{3}{4}$ by $\frac{1}{2}$, was of a delicato pearly piuk before, pure white after blowing - with a few spots of brownish-black towarls the larger end. I afterwards became quite familiar with Loconte's Sparrow and am satisfied that it was tho species whose nest I found on this occasion.-E. E. T., 1885.

This beautiful sparrow abounds in Manitoba wherever there are mealows that offer the right eombination of willow serub and sedgy grass.

About the 5th of May it returns to the Big Plain. At first it is seen ereeping abont among the red willow scrub and last year's sedge along by the sloughs, and uttoring a peculiar "tweete," whence I knew this species as the willow-tweet long ere $I$ had hearl of Leconte or of auy scientific name for the bird. This note is one of these very thin, sharp sounds that are so misleading by their ventriloquial eharacter that one does not know in what direction to look for the "tweeter." On first 
io alkaline its of this inging it is number of fer the flat aken were

he Assini. : "SharpCarberry : ind grassy nt; breed. ent in the os oceur in age and is

tlo through I started a mmediately itly ou the ratted tall. composed ird hurriel tting about me to time at ventriloo bird is in hat region ortance of early pink nish-black r with Leose nest I

there are and sedgy

$t$ it is seen edge along knew this or of any hin, shary or that one On first seeing the speeies elose at hand it strikes one as being much like a bes utitul miniature of the Mealow-lurk.

A.bout the middle of Maty the male begins to "sing" on some low twig, projecting a little above the long grass on the slough. He takes his stand, grasping and keeping his perch with a fixity of manner that hespeaks immovable resolution. Presently he throws loack his head, gapes his widest, and thus with bill pointing to the zenith, arluously la. boring, he is delivered of a tiny, hnsky, double note "reese-retse," so thin a somnd and so ereaky that I believe it is nsually attribnted to a grasslopper, and yet lie ov idently toils harl and brings this forth with snch unetion that lie is quite exhaustol for a time and sits dejected until he reeuperates, whieh he does in abont ten seconds, and once again his little soul is hinskily pourel out and again exhansted nuture asserts her claims, and he subsides once more for the ten secouls of needful rest; but the strain is too great to be kept up for any length of tine, so after five or six rehearsals, from beginning to end without omission or abbre. viation, he is in: such a redncel condition that the notes are no longer andilble at a distance of 20 feet. He now drops from his post of elevation to the lower world and devotes his energies to the aceumulation of protoplasmic reenperation in the form of plant-lice, flies, and caterpillars.

It is interesting and amusing to compare the in tense earnestuess of the Sernb Sparrows in the uttermee of thcir ereaky notes with the cool, off-haml dash, the noriehalance of the Larks and Wool Thrushes when they are stirring hearts and eehues with their inimitable strains.

Another common note of this sparrow is a single, long-diawn "bizz," which also is leceptively like the sound of a grasshopper. This it, repeats at intervals from some perch. When approaclied it drops into the long grass and threals about in the selgy !hieket like an Marsh Wren, although it is inueh less difficult to put up than that birl.

\section{Chondestes grammacus. Lark Sparrow.}

Common summer resident in vieinity of Winnipeg (Hine). Not noted elsewhere.

\section{Zonotrichia querula. IIarris's Sparrow.}

Abundant spring and fall migrant, frequenting thickets. Mouse River, at boundary, September 19 to October 3 (Cones). Portage la Prairie: Common spring and antnmn visitor; arriving about May 15, when they remain but a few lays; reappear abot iseptember 20 , departing abont the 1st of October; whilst here they usually accompany the White-throated and White-crowned Sparrows, feeding in the rank weetts arround the desertel half-breel eluims (Nash). Fort Pelly: In flocks, 50 miles north of Braniton, west of the $\Lambda$ ssiniboine, on the road to Fort Ellice, Oetober, 1881 (Macoun). Carberry : cibmudant spring and fall migrant; Souris River (Thompson). Shell River: 1885, first seen, three, on May 15; a transient visitant; not breeding (Calcutt). 
May 24: Black hooded sparrows are here now in force. Many hearl singing a bar like one individual to this added a warble somewhat like that of a bluebirt. The performance was dis. appointingly short, but the general impression gathered was, that who. ever happens to hear the full song of the Hooded Sparrow will know one of the sweetest of bird molodies. During their spring visit the Blackhoods often uttered three clear whistling notes, and on one occasion a soft bluebird-like warble was alded to this.

Soon after this date, May 24, they all clisappeared as far north as the Duek Mountain; not one wis to be seen in June. In the midalle of October they once more returu and abound for a few days. The young are now with them, but where hatehed and nnder what circumstances is as yet entirely unknown.

192. Zonotrichia leucophrys. White-crowned Sparrow.

Migrant; probably breeding in the northeastern region. Winuipeg: Transiont visitor ; abundant (Hine). Oak Point: 1884 ; arrived May 5 (Small). Portage la Prairie : 'Tolerably common ; spring and autumı visitor; arriving early in May; reapluears abont the 20th September; departs early in October ; first seen, in 1S84, May 15 (Nash). Carberry : Rare; spring and fall migrant (Thompson). It breeds in all parts of the fur countries, arriving in the middle of May and departing early in September to the northern parts of the United States, where it winters (Richardson). Common naar Leaf River (Minnesota), where it breeds (Triple). Severn House (Muray).

Cusa ba ta shish : White-crowned Junting. * * * These birds appear in May and rotire southward before the cold begins; mako a nest of grass and feathers in a bunch of willow or grass; lay four e'ggs ancl sometimes five, of a lusky cast; the young fly about the begin ning of July; their llights are short. When on the wing they are nilent, but when perched on an elevnied npot ret forth a most melodions nong. They feed on insects and secls of grass, ote. (Hutehins MSS., Observations ou Hudson's IBay, 1782.)

193. Zonotrichia intermedia. Intermediate Sparrow.

Abundant at Monse River, at the boundary, in middle of Septem. locr (Coues).

194. Zonotrichia albicollis. Whitu-throated Sparrow.

Common summer resident of woodlands. Winnipeg: Transient visitor; abundant (Hine). English River and Cumberland House: Nesting near Lake of the Woorls, May 29 (Kennicott). Portage la Prairie: A bundant; spring and antumn visitor; aurives about May 15; reappears in great numbers early in September and remains until late in Oetober; the last were seen by me Oetober 31, 1884 (Nash). Very eomınon around Lake Manitoba; breediug at Manịtoba House June 15 (MacouII). Carberry: Common summer resident; breeding; Shell

liver; 1

October

6 ; next

liast of ton). $\mathrm{C}$ eggs $(R$

July 6 tliat yav As I wa was sill the gra full gla with in s dived $\mathrm{I}$ more.

This never: tell me one, thi occasio ing res

On J with a ing tre a brigl About in abu of the sprang ground blaek were n

Oets counts glooin lootin Thi called also h of the 
any heard adcled : e was dis that who. will know r visit the d on one

$r$ north as the inidille ays. The what, cir-

Winnipeg: ived May 5 nd autum! eptember; Carberry : ill parts of rting early , where it til), where

plear in May fenthers in a ky cast ; the on the wing st melodious Observation;

Septem.

usient visIso: Nesta Prairio: y 15 ; re. itil lante in h). Very e June 15 ig ; Shell
River; Little Boggy Creek; Dnck Mountain, breeling; Rat Portage, October ('Thompson). Sluell River: 1885), flist seen, a lair, on May (j; next seen, twenty-one, on May 19; a transient visitant (Calcutt). last of Lako Winnịng (on Nelson River), till September 15 (Blakis. ton). Cumberland IIouse, June 4, 1827: A temale sitting on seven eggs (Richardson).

July 6, 1882 , Shell River: This evening our eamp was on the elge of that yawning crack in the globe at the lottom of which runs the Shell. As I walked along the elge, watehing the setting of a red-hot sun that was sinking amidst, elouls of purple fire, a small wird flew up from the gray wools, now in deep shaulow, to the antlers of a dead tree, in full glare of the sun, and stirrel within me a hunlred latent memories with a song I had not heard for years. For a minute or so he sang; then dived down into the woods, again to be heard faintly and seen no more.

This is a song I have been familiar with from ehildhool; but I have never seen the singer close at hand, and have fonnd no one who conld tell mo its name. I am now satisfiel that it is not, as I was told by one, the Colden.erowned Thrush. I conld have shot the bird on this occasion and so bave gratilied my longing to know, but a gentler feeling restrained $\mathrm{my}$ hand until it was too late.

On Jume 19, IS83, I lound the nest of the peaboly while wanclering with a young friend in a brush slashing wherein were still a feev standing tres. In a more than usually open part a heavy black spruce ancl a bright silver bireh were wrestling togetlier like two giant athletes. About the feet of the wrestlers were beantiful spear shined calla leaves ill abundance, growing through masses of decomposed I wigs-a tangle of the living mot the deal-and from among these, in a drier spot, sprang the peaboly's mate. The nest was a deep cup sunken in the ground among the hlack moss and decayed twigs. It was lined with black fibers, which made it more like its surromdings. 'The four eggs were mottled with a soft purplish gray.

October 7 : Once more in the Shell River Gorge, where first in this eountry I heard the peabody. It was clark when we arrivel, and a gloomy, cold antumn night. Except the rushing of the river and the hooting of an owl, the only sound is the soft whistling of the praborly.

This birl is so well known as a night singer that in many parts he is ealled the "nightingale," and I slanll not be surprised to find that he also has an air song, and is therefore entitled to take rank as a singer of the first order.

May 15, 1884, heart a l'eabody singing a song like this:

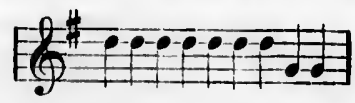

On che chiı i naw ka maw ha sisl.. * * " This burl visits us in the spring and leaves us in the encl of Septembrr. It feels on Hus and worus; builds a nest with 
mud on the ontside and struw or grass on thu inside; makes choice of a situation in trees risised abont a yard from the gromud, and lays from two to five ogge, slotted with black. Also, "kaw sar bac ta po tha shish" " " "This migratory bird is calleol the conjuring birl, becanse it begins singing just before the bad weatlor censes, and furolodes an end of rail, ete., at which time its note is very clear, and seems to re-

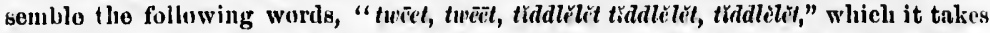
abont a minnte in singing. It makes its nest in willow, Inys four egge, brings forth its young about the miclile of July. (Hutchins MSS., Observations ou Huden's Bay, 1782.)

In 1384 last scen ly mo at Portago la Prinio on October 31, feeding on tho berries of the high bush cranberry (Гibumum opulus), ther' heing 3 or 4 inches of snow on the gromul at the tino. Theso birils do wht loresl anywhere near either Portago la Prairie or Winuipeg. I looked for the biris very enrefully each summer for 6 years but saw noue. (Nash, in MSS.)

195. Spizella monticola. Tree Sparrow.

Abumlant migrant; Irequenting thickets; Monso River, October (Cones). Dufferin: Arrived betore April 15 (I)awson). Winuipeg: Summer resilent; abmolant; migrant (IIine). Portage la Prairio: Abundant spring and antmmn visitor; artives about $\Lambda$ pril 10, remaining nntil about May 15; renpyears about, (October I, mul departs about October 30, the last stragglers remaining until November 2 (Nash). Very abmulant around brush on tho plains in September (Macoun). Carleriy: Very abundant spring nnd full migrant; Rat Portage, abundant in October, 1886 (Thompson). Two Rivers: 1881, first seen, twenty, on March 23; next seen, April (6; migrmut (Crilllle). Shell River: 1885 , first seen, fifty or more, on $A$ pril 11); a transient visitant, passing north and not breeding or remaining any time (Calentt). Lake Winuipeg (north end): September 24, 1857 (Blakistou). Seveln Honse: This bird winters in the United States (Murruy).

September 30, 1884: The Tree Spurrows are liere again in flocks. The cloleful spell is about begimning, lut there is nothing doleful about the Iree Spurrows. Riglit merrily they chase ench otlier from branch to branch on the lenlless trees, twittering gleefully, and ever and anon, as they hingli by in full career, lursts of their music may be heuri, or perchance some member of the merry erew mounts a perch and lets us hear his full song-a song so sweet and vinied that it is surprising to flud his sulggeneric brethren eredited with nothing better than a pro. longerl twitter. It commonly frequents thick eopses rathor than trees, and its general labits would entitlo it to bo culled Serub Sparrow rnther thun Tree Sjunrow. In the springtime it remains here long enough to let us lienr its first attempt it a love song, then it disappears in tho unkilown nortl.

196. Bpizella socialis. Clippuing Sparrow.

One in Smithsonim lustitntion from Red River Settlement; also nt Pembina (Blnkis(ou). Winujperg: Summer resident; tolorably common (Hine). Oak Point: 1884, arriver $\Lambda$ prif 11; next seen on the 12th;

is comn mer res resident arrives

Oı Jur eggers. I loard fro

This 1 April 1 fully til lost sig two pla o! four elge of too late mornin lnnged note of that it almost name,

Very lowlan IInI M D. 0 II Very a 11); des June 1 abunit Fairvi loreedi (Thom summe

JuII slıot a and it ily set

JuII lisping locnlit syllabl at lene Spurro to $\mathrm{Car}$ 
situation in spotted with bird is callat r ceases, and secuns to rehich it takes brings forth indson's Bay,

n the berties of snow on er Portage la or for 6 years

r, Oetober Winnipeg: a Prairio: 10, remain. parts about 2 (Nash). (Macoun). t Portage, first, scen. Ile). Shell It visitant, itt). Lako elll House:

in flocks. lefinl about om lornueh and anou, - lienril, or und lets us rprising to hinI a pro. than trees, b Splarrow hore long lisappears

It ; also nt ly eommon the 12th; is common, and breeds here (Small). Portage la Prairic: Rare; sum. mer resident; arrives abont May 1 (Nash). Carberry : Rare; summer resident; breedling (Thompson). Qu'Appelle: Summer resilent; breeds; arrives April 13 (Guernsey). Commou in Minnesota (Trippo).

On Jnne 6, 1281, foumc a nest (of chippy) at lortage la Prairio, containing three eggs. I have noticed that tho song of this hird is in Manitoba different from that heard from tho species in tho Wast. (Nash, in MSS.)

This speeies is quite rare in Manitoba. The earliest recorl I hare is April 10, 1882, but this was the only one seen at the time, and it was fully two weeks before others appeared. After the spring migration I lost sight of the speeies, but afterwards fonnd it in fill song at one or two places along the elge of the sand hills. It was seen only in three or four localities. 'These were generally ilry, sumny openings on the edge of the woods. I found one nest in a low spruee tree, but I was too late, as the young birls had flown. The male bird is hearl every morning in spring ant early summer, uttering his characteristic, prolonged twitter from some high pereh near his ehosen busl.. Another note of this sparrow is a short "chip," which is so eommomly heard that it has given rise to the orlinary nane of the species. The nest is almost invariably linetl with horse hair, whence the other eommon name, " Mitir birl.."

197. Spizella pallida. Clay-eulıred Sparrow. Ashy-nape.

Very abunlant; summer resiclent on scrubly prairies and lalf open lowlands. Very unmerons about Peembina ; breceling; 'Turtlo Mountain unıl Mouse River (Cones). Rèl River Settlement (C. A. Hubluarì and D. Ommn). Shoal Iake: May 18, 1887 (Cluristy). Portnge la Prairie: Very ubundunt, summer resielent (not at Winnipeg); arrives nbout May 10; departs about Septemlier 15 (Nash). Lake Manitoba and westward, Jume 16 anil 25, 1881 (Macoun). Carberry: In ull sernb lamls; very abmulnut summer resilent ; lorecding twice enel season; Sonris River: Fairview ; nenr Fingerboanl ; near Rapiul City ; near Birtle ; Binsearth ; loreeding every whoro; very aloumlant on west side of Duek Monutnin ("Thompsou). Sliell River: 1855, first seell on May 18; is eommon all summer, and loreels hero; nest with lour eggs fouml (Culcutt).

Jume 28, 1882. Trail 15 miles west of Fingerlourd; in the evening slot a Clay.colored Spurrow. The species is very ubundunt aloout here, and its peeuliur grusshopper-like notes are heard from every pateh of iry sernb land.

Jume 20, Rapid City : All spring I lave heen puzzled hy a singular lisping song that is uttered hy a sunnll sparrow which frequents scrublyy locnlities. The song, if it muy ho so culled, may be represented by the syllubles "seree, serce," sometimes repented two ol threo times. I have at length shot one in the very net, nul find that it is the Clay.colored

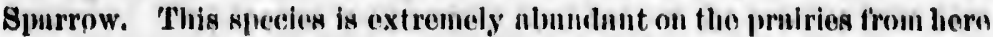
to Carberry wherever there is my lirush wood. Its usual oecupation 
seems to be to sit on some low twig and cleliver itself of its husky notes every few secouls, with all the empressement of a full operu.

June 14, 1884, Duck Mountains: Our cump is in a bluff of low pop). lars and willows out in the prairie, which, however, is more or less scrubby. Here in the rery early morning, before dawn, we are often "wakened by the buzzing "scree, scree" of some near Ashy-nnpe, willing to be thonght a nightingale. The species is remarkubly abnniant about here, so much so that I can ensily find 'liree or four nests of it in an hour or two

On July 28, as I was writing by the window, a family of slattncks came rambling along, six in number, all young birds, colored like old ones, but streaked on the heal and breast and tinged on the wings with a little chestnut. In the long weeds by the window they found a fine hunting ground and spent some time in lunting about, picking up a hundred things which I oould not see at all. Now and then they would adopt the rôle of fly catcher, and one got badly scared by a great red butterfly that flew down beside him, bnt he soon recovered himself and turued the tables by attempting to turu butterfly entelier. Another member of the party was a Saranna Sparrow, who looked quite "bobtailed" beside the Shattucks. Tho whole party contiı !ned rambling and foraging in this manner until at length they rambled out of sight. This seems to be the usual way for young bivls to spend the last of their tirst senson.

This small spurrow arrires in flocks about the 12th of Mny. Its small size and pale, ashy hue will generally iclentify it as it rambles over the serubly parts of the prairie.

The song marking the pairing senson loegins to be liearl townrls the thirl week of May from a lozen points ut oneo and censes about the 10th of August. "Song" I enll it for convenience, but it is the least musical of a number of judifferent performances and is much after the manner of Leconto's Sparrow. This birl monuts some perch und with hend thrown back anl with gaping benk utters a sound like a fly in a newspaper-"scree-screc-screc"-sometimes giving lout one noto and at other times, in the lieight of the season especially, repeating the dulcet five or six times. In the "intromission intervals" lws:ween perform. ances, he sits immovibly with the ontwarl appeurance ancl all the grav. Ity of an uncommonly hord thinker.

The nest is usually finished by the last wrek in May, and at this time the mules have such ample time for their muste thint the scrubby parts "we resonant from lawn to llusk with their jeculinr rasping "louz"."

'T'ho spot chosen for their home is mostly in a low busli, not more than a foot from the grounc. As exception to this rule I liave noted five nests on the gromml and one or two at a height of 3 feet. It is a very slight structure, a gool deal like that of a Chipping Spurrow, but com. posed entirely of grass. When compared with other tree nests it is consprienously flimsy and light-eolored, the lintter effect belng due to the 
absience of the black fibrous roots so enmmonly used as lining. The eggs are among the most beatitiful of any prorluced by the spanrows. When first the discoverer cliaws aside the brush and exposes the nest with its complement his feelings are as of finding an exquisice caskot of jewels. Althongh this is we of the most common of our sparrows, and althongh on the scrubby plain between the Duck Monntain and the Assiniboine in early June, I could have fonnd as many as four or five nests in an hour's walk, the treasure-trove feeling in connection with the egges continues in full force.

I infer from the above and other observations that the Shattuck Bunting breeds twice, if not three times, each season with us. It leaves the "Big Plain" about the end of September.

\section{Spizella pusilla. Field Sparrow.}

Very rare summer resilent. Rel River Settlement: Breeding (D. Gunn). Winnipeg: Sunmer resilent; tolerably common (Hine). Have seen it west of Winnipeg (K. H. Hunter). Qu'A ppelle: Com. mon summer resiclent; breeds; arrives $A_{p_{i}}$ il 15 (Gmernsey).

\section{Junco hyemalis. Slate-colored Junco.}

Abundant migrant frequenting thickets and hillsicles. Probably breeding in the Winnepegosis region, as it loreels in Minnesota (Trippe). Mouse River : At boundury in September; abuedant (Cones). Dufferin : Arrivel before $\Lambda_{\text {pril }} 15$ (Dnwson). Winnipeg: Transient visitor; abmudant (Hine). Ossowa: Common migrant; 1885, first seen, two, April 7; next seen, A pril 16; became common A pril 20; went nortl ahout enl of Mny (Wagner). Oak Point: 1855, first seen, April 3; next seen, April 4, when it hesume eommon; is common and breeds here (Small). Portage la Prairie: Alunlant apring anol antmun visitor ; arrivesabont. the first weok in April, reappeurs enrly in September, and remains until November; the last strigglor I saw was on the bth of that montlı; it is somewhat strunge that 1 conlil never flud any of these birls breediny" here, as I have severul times found their nests in the provinee of Unturio (Nash). Red Deer River nul Assiniboine River, July, 1881 ; probahly breeding (Macoun). Curberry: Vory alımdant migrunt iı spring mul fall; nover seen in summer; Int Portnge, almulant in Octoler ('Thomp. son). Two Rivers: 1884, April; 1885, flrst seen, three, on A jrit 6; next seen, April 17; migrunt (Crilllle). Shell River: 188i, first se(ll, one, male, on April 3; next seen, thirteen, on $\Lambda$ pril 15 ; hecume eommon on April 24; male and lemale in thok; n trunsient visitnut, passing nortl and not broeding or remaining any time (Culcutt.)

Townris the end of $\Lambda$ pril they luenume very nhmodunt; nbont fhat time, in 1884, there whs some sevorn wentlier, with n firesh fill of sulow, mul tho Juncos dismpenred; bnt May.lay proved a benutiful moruing, and every copse und log.pile seemed alive with them and their eomrades, the Tree Bparrows, which mpenred to come firom their various 
hiding places; both species at first uttered a little "peet" from time to time, but when the wenther became warmer two songs were repeit. edly heard from the flock; one a sweetly varied strain from tho Tree Sparrow, the other a twittering something like the ditty of the hairbird, bnt stronger and more hell-like in tho tone. 'This is the song of the Jnnuo; whether it has or has not a more ambitious refrain reserved for the far away secluded del!s of its birth I can not yet say.

About the middle of .llay, all the Juncos and Tree Sparrows disap)pear; not one remains; all go to the far north to ireed. Even in the Duck Monutnin, I saw not a single specimen during the summer.

Towards the end of September these two species return to the Big Plain, in mixed tlocks as before, and continue abont for a week or two, put ready to fly at the tirst intimation of really colld weather or snow.

This is tho ouly species of our common sparrows that, when adult, entirely discurd the streaked plumage, and the fact is perhaps dne to its ehoice of breeding locality, for it alone frequents wooded hillsides, while its near relations are all found nesting more or less in grassy places, where their streaked plumage affords them a means of coucenlment.

The Towheo exemplifies a similar specialization; as its alıit plı. mage more nearly assimilates it to the leaf-strewn ground where it lives, than wonld the streaky plumage of its yonth.

Abont the reconil week in September tho snowbirds or Juncos (Junco hyemalis) began to become abnndnut abont Carberry and renained so for at leust n montl. (Cliristy.)

200. Jumco hyemalis shufeldts. Shufellt's Juneo.

This form accompanies hyemalis in the migrations at Carberry (Thompsoli).

201. Melospiza fasciata. Song Sparrow.

Summer resilent; chiefly in wools along water courses. One speci. men, Turtle Mountain (Cones). Winuiper : Summer resilent; abuu. dant (Hine). Sonthern shore of Lake Winnipeg; loreeding (Keunicott). Norway Honse (Bell, 1880). Oak Point: 1884, arrived $\Lambda$ pril 11; 1885, first seen, one, on $\Lambda$ pril 13 ; next seen on April 15; is common and loreels 'iere (Sinall). Portage la Pritie: Common summer resident; arrives about $\Lambda$ pril 6 ; departs October 1 ; December $30,1885,1$ found one wintering about the stubles on a fiurm at Buruside; he seemed very haply, mul sang as if his surroundings snited him (Nash). Common at Inke Manitoba in 1881 nul on tho prairies in brushy places nenr water; nearly always fall in tho water whon shot (Mncoun). Car. berry : Senree; summer resident; breeding; Portage la Prairie, more common; breeding west side of Duck Monntain; breeding, Rat Portage, in October (Thompsou). Shell River: 1885, fil'st seen, five, on $\Lambda_{\text {plil }}$ 18; seen every diny nfterwurls, hecoming common on April 28; common

silminer

silumuter

July 2:

with fou

'The nest were liar greenish creauny it was lic

This 1

the Nort indiluees $j$ of differe and Ow!

Migra! betr 16, C ('Thomps

Comın lows ab Oak I'o Abunda 2oth Se Septemil abundur Qu'A pIr (Guerus

To th twitteris reerly s

They serumbl ing rees their leg getting ling tlig for the with ne

Whilo chirly, w describ The o twoot.two 
from time pro repent. 1 tho Tree the hair. he song of in reservel

ows dlisel]. vell in the mer.

to the Big ek or two, r or sllow. hen adult, aps dine to 1 hillsicles, in grassy of coucenl.

aduit plu. where it

nco hyemalis) Lst in month.

Carberry

One speciint: abulı. Kennicott). 111 ; 1885, mmon nucl c resident; 35 , I founi cemed very Jommon at laces near uii). Car. airie, moro t Portage, 1 April 18; ; common summer resileut, and breeds here (Calcutt). Qu'Appelle: Common summer resident; breeds; arrives April 1 to 5 (Guernsey).

July 22, 1884, Portage la Prairie: Found the nest of a Soug Sparrow with four eggs. The bird, which I shot, seemed a very small specimen. 'The nest was, as usual, elose by a running stream. Three of the eggs were hardset; one was fresh; the ground color of the three was palo greenish, of the last a delicate cream-color; after being blown the creany became of the same color as the others; one measured $\frac{9}{16}$ by $\frac{12}{61}$; it was heavily spotted as usual; the rest were similar.

This habit of sitting before the clutch is all laid seems common in the North west. No doubt the necessity for saving the eggs from frost incluces immenliate sitting, so that the young inevitably often appear of different ages. (Uf. Kingbird, Vesper Bird, Kobin, as well as Hawks and Owls.)

202. Melospiza lincolni. Lincoln's Sparrow.

Migrant in large numbers at the boundary on Mouse River, Septem. ber 16, October 5 (Coues). Carberry : Rare spring aul winter migrant (Thompson).

203. Melosplza georgiana. Swamp Sparrow.

Common summer resilent; nesting in swanıs that lave some willows abont them. Winuipeg: Summer resident; abundant (Hine). Oak Point: 1884, arrived April 24 (Small). Portage la Prairie: Abundant; summer resident; urrives about April 25; departs about 20th September (Nash). Mouse River, at the boundary, mildde of September to second week of Uctober (Coues). Carberry: Very inbumlant summer resilent; breeding in every slough (Thompson). Qu'A ppelle: Common summer resident; breeds; arrives September 18 (Guerusey).

To the Swamp Sparrows wo are indebted no little for the merry twittering and the bustling signs of life about the brushy sloughs and reely swaups of our country.

They delight in these lamp thickets and may be seen continually sermmbling around in the sedge mil wet tungle or ruming on the thont. ing reeds, holding "their skirts" very high, standiug very high on their legs, with tuils much raised, and ofluerwise showing great fear of getting wet. When they take wing, they thit over tho water with rustling tlight and tail rapielly pumping up und down; they usunlly make for the nearest bush or tussock, and thou appeur to tumble into it with nervous haste.

While flying anil elimbing nbout in the serlge, they often ntter a short chirp, which is realily listinguishinble when once henrl, but con not los described in in way that would mssist in its illentification.

The commonest song of this species is a simple rnpir, "twet.ticet. twot-twet-twot-twet-twet-twel-twet-ticet-twet," all in the stmo note and so 
rapiully as to be almost a twitter. This is utterel at intervals from some deal branch projecting above the rest of the copso. If not disturbed the singer will sit quietly on this pereh for an hour, repeating his ditty once or twice a minute, but if approuched or alarmerl he drops into the tangle, and so elucles both eye and gun. The birl is plentiful in the Northwest, and every willow-fringed slough is ringing with their soug, so that I cau not understand Dr. Coues writing "The song I have never heard."

Nuttall describes the song as a simple twitter, and this is not wrong; but it is long since I leal'nt to aftix a note of interrogation to the state. ment commonly male of many of our passerine birds, " a simple twit. ter is its only note!" Something else is stre to turn up. Why, Wil. son said that of the Vesper Bird! In the gloaming: after sundown on the 20th of May, 1884, I was strolling along the elge of a desolate. looking green and brown skugh, when suddenly a smill brown birl arose out of the sedge, singing in air so sweet and tender, yet strange, that I stood rapt. I never thought of shooting; soon the unknown melody was over and the air song finished with the famiiiar twitter of the Swamp Sparrow.

There was a time, not long gone by, when nearly all the birds were strangers to me, and whenever a new singer was heard or seen I felt something like a shudler, a perfect thrill of delight and anxiety. As I learned nnd knew them one by one, these extreme feelings came less often, for it was only a strunger that had such power to move, and on that evening, the first time for long, I was deeply moverl by the voice of an unknown bird. Snce or twice afterwurds I thonght I heard short bursts of song from the Marsh W'reis that sounded like fragments of the same strains, lut I an inclinel to think thint the mysterious and delightful songster was tho Swamp Sparrow, whose "only note is a simple twitter."

This song resembled the evening elintt of a buywing, but was softer and possessed the charm of weirluess that might have been derived largely from the circumstances nud surroundings.

204. Passerella lliaca. Fox Sparrow.

Migrant, not very eommon, lreeding ut 1nek Mountuin. Dufferin : Arrived between April 15 anl 20(1) (Dwsou). W'imiperg: Summer visitor, abundant (Hine). Portage la Pruirie: liegular but not very common, spring aad autumn visitor; urrives about A pril 22, reappears enrly in () tober, and departs at the end of the mouth (Nash). In voods on Duck :Iountain, September 3; one shot at livingstone September, 1881 (Maeouu). Uncommon spring migrunt at Curberry; abunlunt, breeding on the west side of Duek Mountıin in Jume 1884 ('Thompson). I ob. sorved it between IInison's Bny and Lake Winnipeg (on Nelson River) in Septemlier (Blukistou).

June 19, 1884, Duck Mountuin: The fox Sparrow is quite common 
rvals from If not dis. repeating larmerl to The birl is 1 is ringing ting "The not wrongr; p the state. imple twitWhy, Wil. unclown on a desolate. brown birl et strange, Inknown twitter of

birds were seen I feit ixiety. $\Lambda \mathrm{s}$ is came less ove, and on y the voice ht I heard o fragments terions and $y$ note is a

t was softer sen derived

Dufferin : mer visitor, ry common, u's enrly in n woods on ember, 1881 tt, breetling 30n). I ob. lson River)

ite common liere, and evidently breeding. Its lond ringing notes are to be heard on all sides among the timber on the mountain slopes and in the bluffis that dot the plain. Unfortunately, my eftorts to find a nest were not successful. The habits of this fine birl exhibit muel of the dash and style of the Wood Thrushes; it manitests a lueference for the more open woods, and, when singing, is ofteu perched on the top of some isolated tree.

\section{Pipllo erythrophthalmus. 'Towhee.}

Common sumner resilent in sheltered scrnblands; not micommon about, I'embina, breeding (Cones). Wimnipeg: Summer resiclent tolerally common (Hine). Northwest to Selkirk Settlement (Brewer). Oalk Point, 1885: First seen, two on May 18, next seen on May 19; is cun mon and breeds liere(Small). Portage la Prairie: Common summer resillent; arrives abont June 1, departs about September 20 (Nash). Cariverry : Common summer resident of dry, sheltered scrublaudis (Thompson).

On July 5, 1883, shot a Towhee female, length s; the species is quite eommon aloug the dry, sumn, scrubby banks of the slongh to the east. The common song is like "Chuck-burr.pill a-vill-a-aill-a," it has also a note like "Trece (not Towhee).

By August 30, the Towhee seems to lave gone.

as Solithern Manitoba is about the northmost region of this bird's distribution, full observations on its locil habitat may result in conelusions of gencral interest on the snlject, as the reasous for its ehoice of locality will probably be much more appirent than in its metropolis.

\section{Pipilo maculatus arcticus. Arctie Towhec.}

Along the parallel of 49 agegrees this form becomes established, nt least, as far east as tho Nonse River, where I secured a specimen in September 16, 1873 (Dr. Coues).

207. Habla ludoviciana. Rose-breasted Grosbenk.

Common summer resident of thickets; breeling in abundunce at Pembinn (Cones). Winnipeg : Summer rosicent; abundant; found it as far uorth as Fairford (Hine), north to Selkirk Sut tlement (Brewer). Oak Point, 1884: Arrived Mareh 26 (small). Por.nge la Prairie: Tolernbly common summer resilent, arrives about May 22 . I fouml i nest Jume 7, containing two eggs; ceparts early, probably as soon th the young can fly; uot fouml by me near Winnipeg (Nash). At Lake Manitolu und Red liver abundant, probably breediug (Macoun). Carberry: Tolerably common summer resident (Thompson), Two Rivers, 1855: Saw one on May 25 (Criddle). Shell River 1885: First seen one male on May 14 ; seen every day ufterwarks; is common all summer and ineeds here (Caleutt).

On Juno 28, 188: in a spruce thicket mmong the sandhills, I noticerl a lurge bla:k and white birl, singing a song somewhot like that of the Oriole. The song was stroug and spirited; on my nearer approach, the 
bird disappeared in a tangled thicket, whence at times ho uttered a peculiar "churk," as ho threaled its mazes. I managed, however, to get a good look at him, and found ho was a Rose-breasted Grosbeak.

On July 17, near the mill in the spruce bush, I shot a Rose-breasted Grosbeak, male, lengtlı 8 , extension $12 \mathrm{f}$; stomach full of catapillars small insects, and seeds. The speeies is not uncom non here.

208. Calamospiza melanocorys. Lark Bnnting. Buffulo Bird.

Probably Mauitoban; rare, noted on Souris Plain and west to Cypress Hills (Macoun). Moorsejaw, Northwest Torritory, July 18, 1884. Buffialo Birds quite common (Miller Christy).

(The first of the above records refers partly to the extreme sonthwest of Manitoba, and may entitle this bird to a place in our list-E. E. T).

\section{Piranga erythromelas. Scarlet Tanager.}

liare summer resilent in wowilands. Winnipeg: Accidental visitant at Fort Rouge, just across Main .Strect Bridge, I saw one specimen, a male, May 15, 1887, on the bank of Assiniboine River (Hiue). Sorth to Jake Winnipeg (Ridgway). "I saw one pair only about the 6th June, 1880, in township 13, range 1 east, where I camped for a day (it was the first and only time I hind ever scen the birds, but my companion, Mr. Clementi-Smith, now of Branclon, who had lived several years in Ontario, told me he had seen several pairs ont the shores of Lake Winnipeg), the pair were nestiug when we saw them; they were within 20 feet of us for a couple of heurs. Mr. Clementi hal recognized their peculiar call, for half a mile before we saw them (R. I. Hunter). Qu'Appelle; occurs sometimes, but is rather rare (Guernsey). In Minuesoti, common ('Triple).

210. Progue subls. Purple Martin.

Rare summer rexident. Oak Point, 1884: Arrived May 19; scaree; 1885, first seev, one on Miay 17 ; next seen three on May 20; is common and breeds helo (Small). Winnipeg: Summer resident tolerably common (Hine). Portage la Prairie: Scarce summer resiclent in 1884 ; first seen May 23; common since 1856; later and ut Winnipeg (Nash). Lake Manitoba : Rare; ono pair colleeted at Manitỏba House (Macoun). Oarberry : Rare, and not known to breed; Pembina River (Thompson). Two Rivers, 1885 : First seen, two on May 26; next seen May 28, (Criddle). Turtle Mountain: Breeling (Cones). Slıell River, 1885: First seen, oue male on May 23; next seen, two more same day; not breeding, transient visitant only (Calentt).

On May 18, 1882, at Pembina Miver, near Plum Iake: Found oiso or two hollow oak trees in a thin, scriggy wood, along by the river, that were temanted by half a dozen pairs of Purple Martins. The birds 
uttered a owover, to rosbeak. se-breasted catapillars e.

ircl.

est to $\mathrm{C}_{5}$ ly 18,1884 .

ance soutl. pur list-L.

ental visit. one speci$\operatorname{ver}$ (Hine). y about the d for a day it my comved several the shores thein ; they ti had rechem (R. H. are (Guern.

9 ; scarce; is common rably com1884 ; first eg (Nash). e(Macoun). Thompson). n May 28, iver, 1885: o day; not

mul oise or river, that The birds were seen entering in by holes that had evidently been maile by the Golden-winged Woodpecker.

Sinee 1886 common in Portage la Prairie and Winnipeg during their breeding season. The first $I$ ever saw in the Province arrived at Portage la Prairio May 23 rd, 1884. Thero wero two, a malo and femalo. These birds brod, and after bringing their young ont of the nest remained nutil August 23, when thoy disappeared. On the 13th of May, 1885, several pairs arrived and bred, departing as soon as the young conld fly. Since that thoy have increased greatly. (Nash in MSS).

211. Petrochelidon Iunifrons. Cliff Swallow, Honse Swallow, Eave Swallow.

Vory abundant summer resident. Nesting abont buildings; most abundant of the family, breeding at Pembina, and along the line westward to the Rockies (Coues). Winnipeg: Summor resident; abundant (Hine). "House Swallow" Ossowa (Wagner). Oak Point, 1884: Arrived May 22 (Small). Portage la Prairie: Common summer resi. dent; arrive about May 16; depart usually the first week in Angust; in 1884, first seen May 17, (Nash). Portage la Prairie: Common along the river banks nesting in great numbers in Little Souris and Qu' Appello Rivers (Hine, 1858). All along rivers in the Northwest (Macoun). Carberry : Rare. Brandon : Abundant. Shoal Lake, west: Very common. Fort Ellice: Abundant. Assissipi: Very abuudant; breeding (Thompsonj. Shell River, 1885: First seen, eighteen on May 23 ; afterwards seen every day; is common all summer and breeds Lero under eaves (Calcutt). Qu' Appelle: Snmmer resident, breeds; arrives abont May 10 (Gnerusey).

On May 25, 1882, at Brandon, under an 80-foot, barn eave that faced the south, and stood by the river, I counted fifty-four nests of the Cliff Swallow and the remains or foundatious of many more; many were bunched together in tiers, two or more deep.

On Jnly 4, at Fort Ellice, on the Hudson's Bay Company's buildings along the river, are large numbers of Cliff Swallows' nests. All the higher buildings the Sheltered River Valley have numbers of them under the eaves, but none of the buildings on the hills, or at the elsvated fort, are ormamented.

On June 4, 1884, near Shoal Lake, west, saw above thirty Cliff Swallows' nests under the eaves of a house that stood near a small lake. The birds hal evidently been in possession of their nests for some time, as they were thoroughly repaired, but very few had bogun to lay.

June 6. Assessipi : Although the carpenters have scarcely finished the new mill, and hotel, over three hundred pairs of Cliff Swallows have begun to build under the eaves. The noise of such an extensive colony is discernible at a grent distance, and is not altogether considered pleas. ant by the townspeople. The remarkably favorable circuinstances that have called this colony so soon into existence are high walls in a sheltered hollow, with a suuny exposure ancl proximity to a sheet of water.

Mr. George A. Blake, of Edmonton, las sent me a photograpl, taken in Fort Saskatehewn, which sliows abont fivo huudred Cliff' Swallows' Proc. N. MI. 90_-39 
nests on a singie gable; in some parts the ranks on this photograph are fifteen deep.

Although taking possession of their nests as soon as they arrive, these birds do not begin to lay until 2 weeks later. On the 4th of June I examined a number of these mud bottles on an empty house, a little beyoud Shoal Lake, and was surprised to fiud that although all were tenanted very fow as yet cuntained eggs, and most of these only one. All of these large colonies are placed noticeably near some lake or river, and an examiuation of the gizzard of one shot at this last mentioned place, showed it to contain, besides flies, a large number of water beetles, so that when the bird is seen low skimming over the water and dipping its bill from time to time, it is, beyond doubt, more often feeding than drinking.

About thu 23d of August the Cliff Swallows may be seen leaving the Big Plain in flocks.

Tho cliff' swallow had built its nests in great numbers on the banks of the rivor (Assimiboine, at Portago la Prairie), which rose alont 16 foet alsove tho level of the watsr. I counter no less than thirteen gronps of thom within a distance of 5 miles, whon drifting down in a choe. Tho clitl swallow was afterwurd seon in great numbers on the iittle Souris, the sonth branch of the Saskatchewn, anil the Qu' Appelle Rivers. (Hine, 1858.) 'ihe colonies aro increasing yearly. The, soon e tablish themselves in overy small settlement that is built up and also about furm buildings. Arrive about May 16, llepart as soon as tho young ean fiy woll, usually tho first weok in Auglist (Niash, in MSS.).

2.12. Chelidon erythrogaster. Barn Swallow.

Very rara summer resillent, Mouse River and various other points along tho line (Cones). Winnipeg: Accidental visitant; rare (Hine). Purtage la Prairie: Doubtful (.Nash). Carberry: Rare spring visitant; arrived May 11, 1882, and May 4,1884 (Thompson). Shell River, 1885: First seen, four, on May 30; transient visitants only ; not breeding (Cal. cutt). Qu' Appelle: Summer resident; breeds ; arrives about May 20 (Guernso,y).

I recollect seeing a flock of swallows that tenanted a certain barn in Ontario leave en masse duriug a heavy thunder storm, and pereh on a bare tree in the drenching rain, I suppose, for the sake of the bath. Has this any connection with the notion that swallow-tenanted barns are safe from lightuing? The withdrawal of the swallows during the storm when some barn has been istruek may have, by an aneient and honorable process of logic, given rise to the idea that the circumstances "ere cause and effect.

This birl does not occur near Portage la Prairio or Winnipeg. I once thonght I saw one at the formor place skim past my bout, but as the norning wae very misty and I never suw another, I may be mistaken. (Nash, in MSí )

213. Tachycincta bicolor. Trae Swallow. Wlito-breasted Swallow.

Common summer resideut of rooded regions; at Pembina breeding in sranil numbers (Coues). Winnipeg: Summ resident; abundant 
(Hine). Uak Point, 1884 : Arrived May 3, 1885; first seen, one, on April 28; next seen on May 6; is eommon and breeds here (Small). Portage la Prairie: Common summer resilent in 1884; first seen April 27; arrives about $A_{\text {pril }} 20$; departs enrly in August (Nash). Common along rivers in the Northwest, nesting in old hollow trees at Grand Valley (Macoun). Carberry: Common summer resident; breeding (Thompson). Qu' $A_{p}$ ielle: Summer resident; breeds; arrives about May 10 (Guerusey).

On July 17, went to the White Horse Hill. Found a large colony of White-breasted Swallows nesting in the olt Woodpecker's' holes, with which the timber is riddled, on the margin of the lake that lies north and east of the hill. This is the largest colony I have seen. It numbers, perhaps, twenty pairs. Nearly all of these settlements that I have noted have been close to a sheet of water. However, they are usually to be found wherever the timber is large enough to be hollow, and scarce enough to cast 110 gloom about the chosen district.

214. Clivicola riparia. Bank Swallow. Sanıl Martiu.

Somewlat common summer resilent; local in distribution. Pem. bina: Breeding in colonies, and along the line to the Rockies (Cones). Winnipeg: Summer resident; ubundant (Hine). Portage la Prairie: Tolerably common; summer resident; arrive abont May 22; depart about August 23 (Nash). Very abnndant in the Northwest (Macoun). Portage la Prairie; Assinniboine, near Souris' Mouth; Yellowquills' Ferry ('Thompson). Shell River, 1885: First seen, seventeen, on April 30 ; afterwards seen every day; is eommon all summer, and breeds here (Calcutt). Qu'Appelle: Summer resident; breeds; arrives about May 10 (Guernsey).

Shash g wu o posheu (Martiu). It resorts hither in the begiuning of June; harbors about the steop bauks of rivers, where it breeds in holes, making a slight nest of straw aud feathers, and lays five white eggs. It is the latest breedor of the llulson's Bay fertliorer tribes. I have repeatedly found new-linil eggs in the lattor ond of July, and by the mislde of August not one of the Swallow species is to be seen. A fow dayo before their disappearance they collect in nuubers to particular poyds uigh Severn Settlement, nud ily about uloug the surface of the water.

I have interrogated the uatives who reside here, also those inlavd, concerning the Swallow being fomd torpid meler water, bnt to no pnrpose; indeed, thoy langls at my question. I agreo with tho learned Dr. Forster that Swallows may be unler water unknown to the natives, as they don't examine nuler the ice in the winter; they, for the most part, anglo for fish. (Hutchin's MSS., Obs arvstions on Huclson's Bay, 1782.)

These biris do not breel in colonies here, but excavate their holes in the bank of the Assiuiboine River, singly, und somo distance apart. They are late in nesting. Ou the 21at of July I took out in nest. It was quite now, but contained no eggs. I naw tho old birds going in and out of the hole tho day before, and just previous to my oxamiuing it. (Nash, in MSS.)

215. Ampelis garrulus. Bohemian IVnx-wing.

Winnipeg: Winter risitant; tolerably common (Hine). I have seen these birds in this country in the month of April only (Hunter). Iort- 
ago la Prairie: Regular but not n common winter visitor here; usually in April (Nush). Carberry : Wiuter visitant oneo noted (Thompson).

On November 23, 1886 , saw a flock of about twenty Bohemian Ohatterers, the only ones I have seen in the country. By a marvellous chance, I brought down one with the ritle without seriously injuring it, as the ball simply broke its back.

\section{Ampelis cedrorum. Cel'di' Wux-wing. Cherry Bird.}

Common summer resident of woodlands; Monse hiver, near the Boundary (Cones). Winnipeg: Sunmer resident; abundant (Hine). lied River settlement (Blakiston). As far north as Lake Winnipeg (Ridgway). May 31, on an island on Wimnipeg River, saw a large floek of fifty or more (Kennicott). Pennawa River (Hiul., September, 1857). Ossowa : Common breeding; 1885, first seen one on May 15; next seen May 17 ; became conmon ou May 19 (Wagner). Oak Point: 1884, arrived May 5; scaree (Small). Portage la Prairie: Abundant summer resident; in 1884, first seen June 2; arrives June 1, departs early in September (Nash). Abundaut Manitoba (Macoun). Carberry : Tolerably common summer resilent; Duck Mountain. Portage la Prairie (Thompson). Shell River: 1885 , first seen tive on June 5; is common all summer and breeds here (Calcutt). Qu'Appelle: Oommon; arrives May 22-(Gıerusey).

On July 22, 1884, at Portage la Prairie, found the nest of a Cedarbird in tho woods near the river. It was placed on the branch of a low oak, and was much the samer as specimen taken in the eastern prov. inces. It contained two fresh eggs, from which $I$ infer that the species is a very late nester bere. I do not think it arrives early enough in the season to raise two broods.

Its favorite haunts are the tops of the trees along the river banks, and from these it may be seen to launch out into the air every fow seconds to capture some passing insect, returning to the pereh each time to devour the dainty morsel.

This bird is a most expert fly catcher, hawking about over tho rivers after a epecies of Ephemera that appears in July. When engaged in this pursuit they will remain on the wing for half an hour or more at a time, hovering and working to and fro over a space of 100 yards of water. Generally a good many of tho bircls are in the air at the same time, when the sight is a very pretty one (Nagh in MSS).

\section{Ianius borealis. Northern Shrike.}

Tolerably common spring and fall visitant. Dufferin : Arrived before April 15 (Dawson). Winuipeg : Tolerubly common (Hine). Portage la Prairie: Regular spring and fall migrant; in 1884, first seen April 11; heard of it two weeks before; arriving about April 10, remaining a short time, and returuing about Uctober 1 ; departing at the end of the month (Nash). Carberry : Tolerably common spring and fall visitant (Thompson). Arrives at Carberry April 7 (W. G. A. 
; ; usually hompson). ian Ohatharvellous njuring it,

near the it (Hine). Winnipeg W a largo eptember, May 15; ak Point: A bundant , departs Oarberry : ortage la une 5; is Oommon;

a Cedarh of a low ern prov. 10 species nough in

or banks, overy fow rrch each

or a speoies vill remain nd fro over the air at

rived bee). Por. irst seen ril 10 , reng at the ring and V. G. A.

Brodie). Shell River: 1885, first seen, ono male, on March 14 (Ual. cutt). Touchwood Hills (Macoun). Between Hudson's Bay and Lake Winnipeg (on the Nelson River), September 17, 1857 (Blakiston). Trout Lake Station (Murray).

April 5, 1882: Snow 3 to 4 feet deep everywhere. In the woods to the east shot a splendid Northern Shrike. The vermiculations on its breast were almost obliterated. This was left on the roof of the shants until I had time to skin it. While at dinner we observed another Shrike tearing at a bird on the snow, some yards away. On shooting it I found it was also a borealis; its breast finlly pencilled; and the bird it was derouring was the other Shrike, which it had carried from the roof.

Un October 23 a Shrike came careering -around the stacks after an nnfortunate Sparrow, which speedily took shelter under the litter. The Shrike hovered over it like a Kestrel, and then swooped. I now entered on the scene, and fired, but missed bim. He, however, left the sparrow and dashed off with such an aristocratic air and graceful action that $I$ almost felt $I$ had been engaged in a very small piece of business in thus interfering in the private affairs of a gentleman.

Wa Paw Wisky John, or Great Aslı-colored Butcher Bird of Penuant. This bird harbors at all seasons in tho year a littlo distanco inland and unkes a shrioking noiso. In Aprll it builds a ronnd nest of grass, straw, and feathers, neatly interwoven half way np a jnuiper or pine tree, and lays four ligbt-blne colored eggs. Time of incubation, 15 days. (Hutchins' MSS.; Observations on Hudson Bay, 1782.)

218. Lanius Iudovicianus excubitorides. White-rumped Shrike. Common Shrike.

Oominon summer resilent of half-wooded districts; common breeding; Pembina and Turtle Mountain (Coues). Winnipeg. Summer resident; tolerably common (Hine). Shool Lake May 15 and 20, 1887 (Ohristy). Oarberry : Oommon summer resident; breeding (Thompson). Shell River: First seen, one male, March 14 ; next seen, one female, summer resident; breeds near wy station (Calcutt). Qu'Appelle: Common; breeds (Guernsey).

On May 22, 1584, on a barb of the wire fence, I found a brown cricket firmly impaled. It was evidently not an accident, but the work of a Shrike, for as crickets are found only in August, this must have been in its present position for eight months.

On May 25, found a large yellow burying beetle (Necrophagus) impaled on a barb of a wire fence, no doubt by a Shrike.

On July 6, went with Gordon Wright and Miller Ohristy to the Big Slough on Pine Oreek to see a spring that issues from a bed of petrified moss. Found two nests of the Common Shrike, the young of both broods being fledged and able to fly.

In November saw a number of grasshoppers impaled on the barbs of the wire fence, evidently this had been the work of Shrikes. 
At least one species of Shrike is common and brcels, bnilding its nest largely of the stalks of a species of Gunphalium in the brauches of the low, scrubloy oaks that cover the sand-hills (Christy).

\section{Vireo olivaceus. Red-eyed Vireo.}

Abundant summer resilent of woodlands : Abunclant at Pembina, breeding (Coues). North west to Lake Winnipeg (Brewer). Winnipeg: Summer resident, tolerably eommon (Hine). Portage la Prairie : Com. mon summer resident (Nash). Carberry : Abundant summer resident in woodlands, breeds (Thompson). Very abunilant about Lake Manitoba, breeding (Macoun). Cumberland House, June 2, 1827 (Riehardsoll).

On August 29,1882, O. T. canglit a Red.eyed Vireo down by the Slough. It was hurt in the wing, at least it seemol incipable of flight. It fonght fiercely, biting at the fingers and snapping like an owl. When I laid it down, it threw itself on its back and fought like a hawk; on holl. ing my finger towarcls it, it seized looll with its foot and allowed itself to be carried so. It seemed to have an insatiablo appetite. It will eat us many clragon flies of the largest kind and as fast as we can catch them for it, and they are far from being a rare insect; six of the smaller kinl it swallowed whole in rapil suecession, the larger ones he holds to the perelı with his foot, and breaks thom up before swallowing. One of the latter was given to him nlive and cansed him some trouble; they hul quite a struggle on the floor of the enge before he mastered it, for the dragon fly was rearly as long us himself.

August 31. The Vireo realily eats raw ment. His dietary to-day, in. clucles three dozen liouse-flies, the entruils of a spurrow, six ilragon flies, a couple of large grasshoppers, a couple of erickets, wnd the greater part of mother sparrow.

September 1. Wach day the Vireo disgorges a pellet of the incligestible part of its food. This is globular and ubont one quarter of au inch in iliumeter. This morning he devourel the entruils of a bobolink, a fow cxickets, ant: a number of nnked enterpillurs; the latter he realily ents, but he refuses to touch the huiry oues.

Sejtember 3. The Vireo is deal, it proved a male; lengtlı, 57 ; ex. tent, 9. An An exunination showel clearly that in spite of the enormous menls it had daily ma!le, it had died of stırvition. 'The stomach was quite einpty, the fint everywhere totally ubsorbed, and the brastlono nenrly cutting the skin. From this we may form an illen of the enor. mona quantity of insect fool gnthered ly this bircl when at l!berty and providing for its young as well as itself.

July 17, 1883. To.dny this nest of " Red-nyed Vireo foumd Jum 27, contained one young one realy to fly, nnother bnt hulf grown, แnd an egg which was near being hatched. The nest was composed outwardly of wasj).nest pnper. As usunl with this spocies, tho old hirils diul not appear to be much coneerned nbout mo. They hopped quietly nbout

the br: carele: of the

It is recogi keeps the $\mathrm{w}$ lessly bare frustr the f'a

Sur breed ably Slope On a Vir site nest bireh preci oll $\mathrm{m}$. the altho times why? 
est largely of by ouks that

Pembina, Winnipeg: irie : Oomor resident uake Mani(Richari-

he Slongl. It fought hen I laid ; on holdbwed itself It will eat can catch ho smaller he holls ing. One uble; they red it, for

to-rlay, in. ix ilragon loo greater

incligesti. of mu inclı obolink, a he readily

h, 57 ; ex. enormons nach was renstlono) the enor. berty and

JuI1) 27, I, "unl nu "utwarclly is dicl not tly about the branches over my head, and evidently kept an eye on me, but to a careless glance they might appear to be merely climbing about in search of their prey.

It is difficult to describe the song of this species so that it will be recognized; but once heard it will be remembered, for no other bird keeps up such an incessant utterance of disconneeted bars. During the whole of his serenale the Rell-eye will sit motionless and fear lessly among the leaves within a few feet of one's head, and so often hare my most earnest efforts to sight the voluable songater been frustrated under these circumstances that I begin to nnclerstand how the fable of tho singing leaves may have originatel.

\section{Vireo philadelphicus. Philadelphin Vireo.}

Summer resident of thickets. Summer resilent; it undoubtedly breels about Pembina (Cones). Wiunipeg: Smmmer resident tolerably common. (Hine). Shoal Lake; May 20, 1887 (Christy). West Slope of Duck Mountain breeding, nest found (Thoinpsou).

On June 9, 1884, near Fort Pelly, on the upper Assiniboine I founi a Vireo nesting in a small bluff of poplar and willow. The chosen site was in the twigs of $a$ willow some 10 feet from the ground; the nest was the usual suspended eup formel of fine grass and strips of bireh bark. On the ground immediately below it was another nest of precisely the same muke and materials: intending to take this with me on my return I hmug it in the tree, lout when $I$ came back I fonnd it on the gromu, it was ngain lumg as before, and again thrown down, althongli it had been fimly nt taehed to a twigr. This happened several times so that there was little cloulot that it wis the Vireo's cloing, but why? I can not imugine.

On June 13, the Vireo begin to sit on her fonr eggs. I slot her and fonnd her to eorrespond exinetly with Cones' description of philaidelphi. cus, except that the yellow on the brenst was quite bright. The egge closely resembled those of the Red.eyed Vireo, lut were destroyed by an unfortunate aceident, beforo they were aecenrutely mensurcd. In its habits the birl exhibited the strunge mixture of sliyness and fearless. ness, common to the family; sho would contimue on her nest while I watehed her at a little distumee, and when slarmed would quietly hop on a twig mnd then disappear in the foliage withont uttering a com. plaint.

\section{Vireo glivus. Warbling Vireo.}

Sunner resident of woorlanils; in ubundnuce at Pembina (Oones). Winnipeg: Summel reslant; tolernbly common (Hinc). Selkirk Settlements (lirower). Lortnge ia l'ruirio: Oommon summer resident (Naslı). Curberry: Common summer resilent; south slope of Rirling Mountnin, west side of Dnek Mountain ('Thompson). 


\section{Vireo flavifrons. Yellow-throated Vireo.}

Rare summer resident. Winnipeg: Rare; accidental visitor (Hine). July 18, 1884, Miller Christy brought me specimen of Yellow-throatel Vireo from Moosejaw (Thompson).

\section{Vireo solitarius. Blue-headed Vireo.}

Rare snmmer resident; one secured at Pembina June 4 (Cones). Winnipeg: Rare (Hine). Long River: Duck Monntain; apparently breeding (Thompson).

On June 10, 1884, at Duck Mountain, a solitary Vireo was obserred. It was uttering a note like peechoeec, somewhat like tho call of a Goldfinch or a Linnet.

224. Mniotilta varia. Black-and-White Warbler or Creeper.

Pembina: Juue; probably breeds (Coues). Red River Valley : Sum. mer resident ; common (Hunter). Winnipeg : Summer resident; toler. ably common; breeding (Hine). Portage la Prairie: Rare summer resident; arrives about May 15, denarts in August (Nasl1). Waterhen : River. Probably breeding; Juno 24, 1881 (Macoun). Rare at Cnmber. land House (Richardson). Oarberry: Common in nigration. Duck Mountain : Common; breeding (Thompson).

June 10, 1884, Duck Mountain : The Black-and. White Creeper is an abuudant species in the spruce wools here; its note is a thin twitter, like a Cedar-bird in a hurry ; it may be suggesterl by the syllables, "Chipili, chipiti, chipiti, chipiti," uttered fuster and finster till it be. comes a mere twitter.

225. Eelminthophila ruficapllls. Nashiville Warbler.

Rather rare; summer resident of woodlands. Winnipeg: Summer resident; rare (Hine). Duck Mountain: Brceding (Thompson). Cum. berland House: Male, May 15, 1827 (Richarison).

On June 11, 1884, at Duck Mountain, I found the Nashville Warbler in full song and evidently breeding. Its warble is something like that of the Summer Warbler, and may be rendered, "Toit toit toit toit chip-it-e-ip-it.e ipitipitipitipiti," the last part being a continuons twitter.

226. Holminthophlla oelata. Orange-crowned Warbler.

Common summer resident in woolland. Monse River: Abunilant at the boundary in September(Cones). Winnipeg: Summer resident; rare (Bine). Oarberry: Common summer resident; breeding (Thompson).

On Muy 12, 1883, shot an Orange crowned Warbler. It wus flitting about with great activity among tho poplar catkins, ancl, from time to time, uttering a lond song like " ohip.e chip.e chip.e chip.e ship.e."

On May 14 I shot another Orange-crownel Warbler. Its song is much like that of the Ohipping Bparrow, but more musical and in a h/gher key.

The b ainong once is near $\mathrm{C}$

229. D 
The birl is extremely restless and lively, moving about continually among the topmost twigs of the trees and uttering its little ditty about once in every half minute. I bave noticed it in all the wooded sections near Oarberry, and am disposed to believe that it breeds here.

\section{Eelminthophila peregrina. Tennesseo Warbler.}

Rare summer resident. Pembina: Common ; migrating early in June (Coues). Winnipeg: Summer resident; abundant (Hine). Northern shore of Lake Winnipeg, June 6 (Kinnecott). Duck Mountains. Tolerably common; breeding. Carberry : Fall (Thompson). Cumberland Honse, May 28, 1827 (Richardson).

June 11, 1884, Duck Mountain : Tennessee Warbler is somewliat com. moll. It uxually frequents the beavy timber, and, in its activity and general habits, it presents the same features as the rest of the family. Its soug begins with a note like chipiti, chipiti, repented a dozen or more times, with increasing rapidity, then sullenly cluanged into a mere twitter.

June 12, Dnck Mountain. Collectel Tenuessee Warbler; apparently breeding.

\section{Dendroica tigrina. Cape Mny IVarthler.}

Common summer resic!nut. Winnipeg: Summer resident; alonndant along the river (Hine). North to Lake Winuipeg (Rilgway). Shoal Lake, May 16, 188: (Christy).

229. Dendroica aestiva. Yellow Warblor. Spiller Bird. Willow Warbler. Wlllow Wren.

Summer

). Oum.

Warbler like that toit toit twitter.

ndaut at ent; rane ompson). s flittling om time ip-e." is mueh gher key.

Very abuudant summer resident in thiekets everywhere. Abundant, Pembina and Mouse kiver at the boundary (Cones). Wimnipeg: Abundant; breeding (Hine). Slioal Lake, March 16, 1887; common (Christy). Ossowa: Common; breeling ; 1885, first seen, one on May 18; next seen, May 19; became common, Many 20 (Wugner). Oak Point, 1884: Arrived, May 26, 1885; first seen, one on May 16; next seen on May 23; is common and breeds here (Smull). Portage la Proirie: Common snumer resident; breeling; arrives ubout May 16; depnrts early in Auguat (Nnsh). Common; breeding throughout the Winnipegosis region; the common species of Poplar brush. Lnke Manitoln, June 15 to 20 ; Waterhen River, June 23 (Mreoun). Shell Rirer, 1885 ; first seen, three on May 15; ufterwarls seen every dny ; is common all summer, antl breels hero (Calontt). Qu'Appelle: Com. mon summer resident (Guernsey). Corberry : Abundant summer resident. Breeding also in all wooded locelltles from Carberry to Fort billice (Thompson). Trout Lake Station: Sevory House; known throughout the whole of the fur countries (Murriy).

June 3, 1884, Rapid City Trail The numerous groves along the 
trail here are vocal with the merry warble of the Yellow Warbler. It is one of the commonest birds of the district, and is to be found in all the poplar and dry willow clumps. A specimen collected was a male in full song and very rich plumage, in its stomach was a mass of various insects.

September 8th: Yellow Warblers are singing and going southwarl.

230. Dendroica coronata. Myrtle Warbler.

Abundant migrant; a few breed liere; abundant in September; along Mouse River at the Boundary (Cones). Dufferin: Arrived between A pril 20 and 25 (Dawson). Winnipig: Summer resident; abundant north (Hine). Shoal Lake May 18, 1887 (Cliristy). Portage la Prairie: The most abundant Warbler we have, in spring and autumn, arrives about May 1, re-appears in August and departs about the ent of September (Nash). Lake Manitoba, Jume (Macoun). Carberry: very abundant migrant; Souris River; Turtle Mountain; Portage la Prairie; breeding, common on Duck Monntein (Thompson). Shell River, 1885, first seen, ninteen, on April 30; afterwards seen every lay in migration ; a transient visitor, only passing north and not breed. ing (Calentt). Cumberland, May 28, 1827; House (Richarlson).

May 5, 1884: Flocks of malo Myrtle birds have made their appear. ance. The bare branches of the yet leafless trees are enlivened hy them every where, as they flit about in pursuit of the myrial insects, they look like small Flycatchers and the partial illusion is increased ly the oft-repeated note, which is much like that of Empidonax minimus.

On Jume 10, Duck Mountain, shot a male Myrtle bird. The species evilently breeds here, its song is frequently heard in the spruce woods, it partakes of the same general character as that of other Warblers. It resembles the syllables, "pheo phen pheo pheo pheo phen pheo, phew" pheo, pherc phee, pheso phec, phero phee, pheo phee, pheso phee." The first part being nttered very rupidly, and the list with more deliberution.

September 12, Portage la Prairie: The town to.lay is fairly flooded with Warblers in antumual plumage, passing sonthwarl. Yollowrumps constitute a very large proportion of the host that is mnking the returu jouruey. Their ruuks are now swelled by great numbers of the young, whose liveries are so varions anl often so very un-yellow. rump-like, that they may cunse the beginner no little perplexity.

231. Dendroica maculosa. Mngnolin Warbler.

Rure; migrant. Winnipeg: Sumıner resident; common (Hine). Found at Duck Bay, Lake Winnipegosis (Mncoun). This is a common bird on the banks of the Saskateliewan: Cumberlaul Houso, Mny 26, 1827 (Kicharison). Carberry : I observed a small tlock, and secured a singlo specinen in young plumage, August 24, 1884 (Thompson). 
w Warbler. be found in ected was a is a mass of south warl.

September ; Arrivell be. lent; abun. Portage la inci autumn, out the end Carberry : Portage la son). Shell scen every id not breeel. (lsou).

heir appearnlivened by rial insects, inereased ly ux minimus.

The species oruce wools, er Warblers. o pheo, phew "The first liberution. airly flooded d. Yellow$t$ is muking $t$ numbers of y un-yellow. loxity.

line). Founsl common biril May 26, 1827 ured a single
232. Dendroica pensylvanica. Chestnut-sided Wurbler.

Common sumıer resident in woodlands. Pembina: One female specimen, June (Coues). Winnipeg: Summer resilent; abundant (Hine). Portage la Prairie : Tolerably common summer resident; arrives about May 30, departs in Augnst (Nash). Lake of the Woods : May 29 (B. Ross). Carberry : Abundant iu migration; commonly breeding; Duek Mountaill, commonly breeding (Thompson). In Minnesota rather rare; breeds (Trippe).

On June 21, 1883, while at the spruce bush collecting, i heard the loul song of what proved to be the Chestnut-sicled Warbler from a eertrin grove of tall poplars. The specimen collected was a male; length, 5 ; stomach full of small insects ; evidently it was breeling. It is a true Warbler, bei:ag seen and heard continually among the trees. Its choice of locality usually causes it to be found chiefly in half-open woods, es. pecially along the edges of low, marshy places. While singing I have always observed that it kept among the branches of the taller trees. Its song is somewhat like that of the Orange-crowned IVarbler. I can recall it to minal by the aid of the syllables "Chip.e, chip.e, chip.e, chip.e, ehip.e, wai chip," the single emphatic syllable near the end being the most tangible diffierence.

June 10, Duek Mountain: The Chestnut-sidel Warbler is quite con!. mon in this woorled region, and is, no donbt, breeling here. It frequents the tops of the highest trees, and from time to time utters, with little variation, the alrealy described song.

\section{Dendroica castanea. IBay-breasted Warbler.}

Rare; summer resiclent. Wimnipeg: Summer resident; rare ; found along the river (Hine). North to Hudson Bay (Riılgway). Portage la Prairie: Lnther uncommon; summer resident; arrives abont May 30 (Nash).

234. Dendroioa striata. Blackpoll Warbler.

Rare; migrant; probably breoling. Winnipeg: Summer resiclent; tolernbly common; probably breeding (Hine). Carberry : Rare; spring Higrint; notel once only (Thompson). Cnmberland Honse: May 25, 1827 (Richarison). Trout Linke (Murray).

235. Dendrolca blaokburnlae. Blackluurnian Warbler.

Rare; summer resident. Winnipeg: Snmmer resident; tolerably conimon as fur uorth as Big Islund, Lake Winnipeg (lline). Swan Lake mud Poreupine Mountnin: Probably breeding (Mncoun). Carberry; June 3, 1883, anw a male Blackburnim Wurbler to.lny, the only one I have observed in the country (Thompson). "Sylvicola parus," Severn House: Trout Lake Stution (Mnrruv). 
Rare summer resident of the wooded country to the north and east. Winuineg, Common (Hine). Tolerably common in eastern part of the province, shere they appear about the end of May (R. H. Hunter). Duck Bay, Lake Winnipegosis, latter part of June (Maconn).

\section{Dendroica paimarum. Palm Warbler. Rudpoll Wariier.}

Abundant migrant, on the prairies as well as :a woors. Red River settlement (Brewer). Winnipeg: Abundant in migration (Hine). Carberry: Abuudant migrant on the prairie, chiefly in spring, Port. age la Prairie (Thompson). I saw only one individual at Unuberland Honse, May 26, 1827 (Richardson). Minuesota: Goes further north to breed (Trippe).

On May 14, 1883, I saw great numbers of Redpoll Warblers. They were in the bushes and also straggling all over the prairie; far from timber aul not exactly in flocks. T'hey are noisy, restless birds, ancl, as many observers have remarkel, they are largely terrestrial, and have many of the habits of the Pipits. I collected three specimens.

It passes through this neighborhood and during the summer has not been seen. Yet from the facts that it is exceedingly common here and rare at Uumberland House one might almost infer that it breeds in the Duck and Porcupine Mountains.

\section{Selurus aurocaptllus. Ovenbird.}

Conımon summer resident of woodlands. Winnipeg: Summer resilent; abundant (Hiıe). Bizeding near English River, July 15 (Kennicott). Red River Valley : Summer resilent; tolerably common (Hunter). Portage la Prairie: Tolerably common summer resident; arrives in May, departs iu September (Nash). A lunnilant around Lake Manitoba; doubtless breeding (Macoun). Carberry : Tolerably coinmon summer resident; breeding (Thompson). Cumberland House, June 2, 1827; breeds (Richardson).

In Manitoba my opportunities of observing this bird were very few, but since then, while resident in Ontario, I have been most advanta. geously sitmated for cultirating its acquaintanco. I have in particular become very familiar with the famous air-song, so long a puzzle to the uaturalists, that it utters in the evening while floating in the air above the tops of the forest trees. This song may be heard daily during the nesting season by those who know when and where to lieek for it, and, so far fro'sl being unusual, it will be heard more often, even, than the ordinary "teacher" refraill, which seems to be but !ittle more than a call note. One of the most interesting facts about this lark-like song is that it may be heari at almost any hour of the night in the grove where a pair of these biris have settleil for the love season. 
239. Beiurus noveboracensis. Water-thrush or Wagtail.

ih and east. part of the H. Hunter). ).

ier.

Red River ion (Hine). pring, Portjumberland er north to

lers. They ie; far from birds, and, al, and have ens.

mer has not on liere and reeds in the

ummer resiy 15 (Kenni. on (Hunter). ; arrives in o Munitoba; hon summer ne 2, 1827;

re very few, st advanta. il particular puzzle to the he air above $y$ during the for it, and, on, than the more than a rk.like song in the grove

Summer resident along water-eourses. Winuipeg: Sunmer resident; abundaut (Bine). Red River Valley: Summer resident; tolerably common (Burter). Around the lakes of the Northwest Territory (Macoun). Carberry: Augest, 1884 (Thompson). Severn House (Mur. ray).

On August 9, 1884, at Humphreys Lake, I found the Water.wagtail very numbrous for the first time, so that evidently the species is migrat. ing. They were to be seen all along the margin skipping about over the floating rushes and bladderwort (utricularia), bobbing their tails and uttering their "chit chit" in a tone very like that of a Myrtlebird or Least Flycatcher. They are, however, even more noisy when in the traes. One speeiment which I shot seemed as much annoyed by my intrusion as though it had a nest close at hand; this ouv was 6 inches long; stomach full of small insects.

\section{Geothlypis agilis. Connecticut Warbler.}

Somewhat common summer resident of tumarac swamps. Winnipeg: Rare (Hino). Carberry: Tolerably common; summer resident; nest found June 21, 1883. Duek Mountain : Tolerably common; probably breeding (Thompson).

On June 21, 1883, I found the nest ant eggs of the Conuecticut Warbler. On June 29, in the spruce bush, I shot a Connecticut Warbler, a male; length, 6 inches; stomach filled with insects; it haunted the tops of the low tamaraes and sang a song like "Beecher.beecher.beecher. beecher."

June 14, 1884, Duck Mountain: One or two pairs of Conuecticut Warblers are breeding in the tamarac swamp near here. Besides the soug alrendy recorded I have noted another type; it nearly resembletl the syllables "Fru-chapple fru-chapple fru-chapple whoit," and is uttered in a lond, ringing voice, quite unlike the weak, hurried lisping of the Wood Warblers, which are nesting abundautly in the adjoining dry spruce woods.

The life history of this graceful species $\mathrm{l}$ as so long continued involved in obscurity that it is with exceptional peasure I find myself enabled to cast light upon several of the most important of its habits. I hal the good luck to find its nest, the first of the kind known to science. (This was subsequently sent with the bird to the Smithsonian Institu. tion, where the identifleation was confirmed and the nest finaily deposited.) The find was anuounced in the "Auk" (April, 1884, p. 192). I reproduce the article :

A fow miles south of Carberry is a largo opruce busb, and in the middle of it a wido tamarao swamp. This latter is a gray mossy bog, luxuriant only with pitcher plants and droserw. Orer its surfice at regular intervals, as trough plunted by the hand of man, grow the slim, straight tamarace, grizzled with moss, but nou dense nor at all 
orowied; their light leafage casts almost no shaile, so that they always look as thongh just abont to end, thongh the swamp really continnes for miles tho samo durkgray waste. I hal often visited the bog when on exploring expeditions iu the neighborhood, bnt seldom found any birl-life of speeinl interest. On the day mentionet, while ont collecting, I laal braved the mospuitoes and traversed tho bog for somo dis. tauce, when besille the whistling clonks of tho great crested and olivo-sided Fly. catehors, usmally the ouly birl voiees of the place, my ear caught the clear soug of a Warblor. It mny bo suggesterl by the syllables "beecher-beecher beceher-beecher becherbeecher." It was sonewhint like the song of the Oven-bird, bnt difforent in being of the same pitch thronghont insteal of beginuing in a whisper avel increasing the enpluasis and strength with oach pair of notes to the last. Guiled by the sonud I found tho birt high up in a tanarae. It was mneh less shy than the Wood Warblers, so that it was easily recured. It privec to bo a male Comectient Warblor.

As I went on a suall ind spery suc louly from one of the grave-like moss-mounds

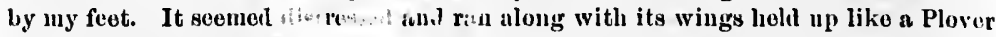

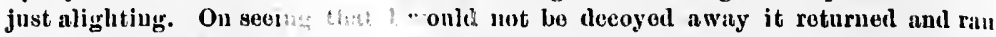
arouml ine in the same at:

crognizing it as tho Connectient Warbler I stiflel all feelings of pity, added the birl o inv bing, and then sought out the nest in the moss: It wis emposerl entirely of finc iss and sunken in the ground as alrealy described. The eggs, four in number, measured .75 by .56 inch. Before being blown they were of a delicato cremuy white, with a fow spots of lilac, purple, brown, and black inelinel to form a wreath abont the large ond. The ereany white gromud color was replacerl by white after the blowing process. The female was as follows ; Length, 5:3; stonach full, many colooptora and wno catorpillar; but little ash on head. Male, length, 6 ; head anil breast uleir asl., withont brownish tints.

\section{Geothlypis philadelphia. Mourning Warbler.}

Common summer resident of lly scrub lands; breeding abundantly at Pembina (Coues). Winnipeg: Summer resident; abundunt (Hine). Selkirk Settlement (D. Gmun). Very abundant at Waterhen River and Swan Lake; nest takel June 28, 1881, in a low busil of Corylus ros. trata, about 4 feet from the ground (Macoun). Carberry: Common summer resident in the wooded thicket abont the spruce bush; Duck Mountain (Thompson).

On June 22, 188\%, while at the spruce bush, I shot a couple of Mourning Warblers. It is quite common here. I usually found this merriest of mourner frequenting dense, serubby undergrowths on ilry land, a choice of locality, which contrasts greatly with that of its near kinsman, the Maryland Yellowthront. It is a very difficult birl to get sight of by following it. On one occasion I had been creeping and crawling about in a thicket for over an hour in a vain attempt to se. cure one of the many Mourning Warblers that were uttering their loud "woichy woichy woichy woichy woi cha cha." Although I was often within 20 feet of a specimen I failed to obtain sight of a single one, until, at last, tired of this hide anil seek game, I sut down on a $\log$, re. solving that if they would not wait for me to come to them, I wonld sit and wait for them to come to me. I then sut perfectly still for a few min. utes. The simple warble was defuntly sounded in a near thicket a few times; then, as I did not move, the little bird suddenly flitted up to a higher post of observation within my view, aud presently $I$ put it in my basket. 
ways look as lo same darkin tho neighy mentioned, for some dis. vo-sided Flylear song of a eccher beccherit in being of asing tho ensommil I found Warblers, so or.

moss-mounds like a Plover imed and rü urbler I stifled ho nest in tise as nirealy cle. ny blown they w'n, and blauk and color was ; Length, 55; head. Male,

abundantly lint (Hine). :rhen River Corylus ros. 5 : Common ush ; Duek

a couple of found this $w$ ths on diry of its near bird to get ceping ant ompt to se. tering their I was often single one, on a $\log , \mathrm{l} e$. I would sit r n fow min. hicket a few tted up to $\mathrm{II}$ I put it in

\section{Geothlypis trichas. Maryland Yellowthroat.}

Oommon suminer resident of dann thickets; Pombina and Turtlo Mountains (Coues). Winnipeg: Summer resident; abundant (Hine). Shoal Lake: May 23, 1887, several seen, but not in a flock (Christy). Oak Point: 1884, arrivel May 26 (Small). Portage la Prairie: Abundant; summer resident (Nash). At Waterhen River: Breeling; nest not on gronud, but elevated a foot or two on the land, subject to floots (Macoun). Carberry: Common summer resident; Duck Mountain; abundant; breeding (Thompson).

On June 2s, 1883, shot a Maryland Yollowthroat. Its song was like "Rap-pittity rap pittity, vap-pittity rap." The species is very abundant in the alder thickets along by the small lakes and ponts.

June 8, 1884, Duck Mountain: The Maryland Yellowthroat is an abundant species about here. Its favorite haunts are low, damp thickets, so that it is, in a meesure, tho complimentary species of the Monrning Warbler, which manifests a liking for none but the driest $c$ ? copses.

Like the Mourning Warble", also, it seems to take a mischievont delight in playing "Jack o' Lantern" to the collector, for it will ad one for hours through a maze of dank alilers and water-willows, rans ing, now and then, to eneonrage its distressed, mul-splashed, brit! hescr:iched follower, by ealling londly and plainly "What a pity, u a pity, what a pity, pit," or again, when the persevering ono has happened on some new accillent, it annonnces its whereabouts in notes, which, by a slight stretch of the imagination, may be rendered "What's the mat. ter, what's the matter, what's the matter, mat." Often as has happened with myseli the ardent collector will, at length, find that, after all his trouble, this black-masked “ Will o' the wisp" has quiotly left the neighborhood when it found the plot thickening too much for its anusement, ancl yet, all this time, perhaps, it has never once exposed itself to the eyes of the gunner.

To.day, while watching one of this species, I was surprised to see it suddenly spring up abont 10 fect in tha air, where, hanging poised, with its legs and tail dangling down, it uttered n prolonged and musical chant that listerl for nearly half a minute, then dived into the willows to tuke up tho "whut.(a-pity" notes where it left off. But for thoplace, (the Upper Assiniboine,) and the plain view I hat of the diminutive birl, I shoull have been sure that it was the Yellow-breasted Chat that had performed for my benefit, se nearly did the actions nnl voice of the Yellow throat resemble those accredited to the droll Ieteria. This song partook of the continuous and voluble character common to all air. songs, and due, it is supposed, to the vigorous motion of the wings reacting on the pneumatic system of the bird. 
243. Syivania pusilla. Wilson's Warbler. Black Capned Flycatcher.

Not common, chiefly as a migrunt. Winnipeg: Summer resident; somewhat plentiful in spring and fall (Hine). Near Long River, May 21, 1882, saw a Black Capped Warbler (Thompson.)

\section{Bylvania canadensia. Canadian Warbler.}

Summer resilent of wooded hillsides; nortl to Lake Winnipeg (Ridgway). At the head of Lake Winnipegosis, uilldle of July, 1881; not common; probably breeding (Macoun). Carberry : Rare ; spring migrant ('Thompson). Cumberland Honse: Male, Jute 6, 1827 ; from the time of year in which it was seen, we have no donbt of its breed. ing in that quartor (Richardsoni).

On June 3, 1883, I observed a Canadian Warbler in the woods to the eastward. This is my only Manitoban record. I append a note made in Untario on this specios in $\mathbf{1 8 8 5}$.

Although this bird is not rare and has a wide breeding range in our own territory, its babits are not at all well known. I usually found it frequenting the bases and northern slopes of thickly wooded hillsides or alder thickets on the adjoining flats. Its song is loud and striking, and may bo syllabically renciered "rup.it che, rup.it-che, vup-it-chitt-it.lit." In the springtime it is heard hourly about its ehosen localities, but alter midsummer it is silent, having, I believe, no fall song period.

\section{Setophaga ruticilla. American Redstart.}

Common summer resident of that wools; very abundant at Pem. bina; breeds (Uoués). Winnipeg: Summer resident; abnudant (Hine). Common near Rainy Lake May 26, and near Lake Winuipeg June 6 (Keunicott). Shoal Lake, May 23, 1887 (Christy). Portage la Prairie : Common, ehiefly in spring; summer resident; iurives nbout May 16; departs at the end of September (Nash). Very abundant around Lake Manitoba (Macoun). Carberry : Long River; Duck Mountain ; breeding ('Thompson). Shell River : 1885, male, first seen, one, on May 24; next seen, five, ou June 2 ; first, fimale, May 26 ; next seen, three, on June 2 ; transient visitant, going north (Oalentt). Cumberland House: Male, May 20, 1827, and June 30, 1830 (Richardson).

June 8, 1884, Duck Mountain : Fonud tho dainty nest and eggs of a yet more dainty Redstart in a low fork of a sapling. The mother bird seemed greatly distressed when she saw me approach her treasure. She flitted close to my head, and ran, beseechingly, on the ground at my feet, and "chipped" most plaintively. But midst all her grief she never ceased to catch thies whenever one of these tender morsels came within reach of her ready bill.

Ne-mis-cu Apethayshish * * It derives its uame from ne-mis-cr (thuoder), because its note is heard but seldom except before thunder, which it therefore fore- 
stcher.

$r$ resident; River, May

Winnipeg fuly, 1881; re ; spring 1827 ; froin its breed.

oocls to the note made

ange in our ily found it ed hillsides ad striking, -clitt-it.lit." salities, but period.

nit at Pem. lant (Hine). peg June 6 la Prairie: put May 16; round Lake tain ; breed. on May 24; in, three, on aud House:

d eggs of a mother bird er treasure. lo ground at er grief she corsels came

-cri (thunder), therefore fore- tells; plentifnl inland in sammer, bat migrate southward in the winter; but I could not learn any more of its natural history, its not being known to the uatives near the Albany Fort, where this specimen was shot. (Hutchins, MSS., observations on Hudson Bay, 1782.)

246. Anthus pensllvanious. Amorican Pipit, or Titlark.

Abundant spring and fall migrant. Winnipeg: Transient visitor; tolerably common (Hine). In cousiderable numbers along Mouse River in September (Coues). Portage la Prairie: Abnndant; autumn risitor; I have not noted it in spring; arrives about September 20, and remains until tho end of October (Nash). At Pelly: September 15, 1881 (Macoun). Carberry : Abundant; migrant; Turtle Mountain (Thompson).

October 8, 1884: Pipits are here in much greater numbers than in the spring, and are bustling about in the barnyards and pastures, first attracting notice by their untiring repetitions of the note "chepit, chepit." Then, holding the attention by the remarkable habit they have of wagging the tail unceasingly, whether flying, perching, or running on the ground; they seem to be under some awfu' obligation to keep on wagging, not their tails only, but the whole of the latter end. The motion is absurdly excessive, and the birds look as though they would stop it if they could.

\section{Anthus spragueil. Sprague's Pipit. Missouri Skylark.}

Common summer resident of tho elevated prairies of the south and west. Winnipeg: Rare (Hine). From Pembina Mountain westward along the bonndary to the second crossing of the Mouse Riv or; breeding in great numbers; Turtle Mountains, Mouse Rirer, etc. (Coues). Oarberry: Abundant; summer resident (Thompson).

On May 7, 1.883, I noticed the Missouri Skylark, or Sky Jingler as wo used to canl it.

May 7, 1884: Have at last succeeded in collecting \& skylark that I kisew to have been singing aloft. It appears to be Anthus spragueii (identification subsequently indorsed by Dr. O. Hart Merriam). Male alult: Length, 61; weight, $3 \frac{1}{4}$; tail, $2 \frac{1}{4}$; beak, $\frac{3}{8}$; toes, $\frac{7}{8}$; hind toe, $\frac{7}{8}$, of which claw is about half; toes reach beyoud the tail; stomach full of coleoptera. It differs from Baird's description as follows: It has vibrisse, the outer tail feathers not entirely white; the outer toe not quite free; first primary not longest, but second and third are; tail even, not emarginate; legs aud bill not yellow, but flesh-colored. It is an extremely shy bird, and for long I confounded it with the shorelark, whose song and.habits on the wing are so similar.

On May 10, I counted twe ve skylarks singing far np in the sky, during a 3-milo walk in the ", vrning.

May 13. Skylarks very $\mathbf{J}$ :erous now, and in full song.

On May 14, I watched . skylark that was singing on high with Proc. N. M. $90-40$ 
great devotion; he had trilled his refrain from beginning to end a If ast twenty times when it occurred to me to time and count his songs. The whole of each trilling occupied 15 seconds, and after I began to count he repeated it from beginning to end eighty.two times ; just as he should have entered on the eighty-third, his wings closed, his tail went up, and down be fell headlong; but my eyes were blinded with the bright. ness, and my neck refused to take part in furtber proceedings, so that I was not able to mark the bird for closer examination. This singer had serenaded me for about an hour, and I do not think he ranked above his fellows in staying power.

On May 19 collected a skylark that sang its song only twenty times before it dashed down to earth. Saw another singing on the ground; this is the only case of the kind I have observed. It is one of the com. monest of prairie birds in western Manitoba. Its lond ventriloqual voice is heard from the clouds on all hands when it is in full song. This song was for loug a riddle past my solving. I felt sure of its being the utterance of some bird on the prairie, but where, I could not tell nor trace; wherever I went, it seemed to be just a little further ahead, or to one side or another, or suddenly behind. Thronghout the whole season of 1882 I was thus duped, and it was by chance that at last I fuund the singer to be away up in the sky, but so high that as it was a bright day it was impossible to follow with the eye the tiny speck whose music was shaking the air for thousands of feet around. The song is sweet and far-reaching, and both Audubon (the discoverer) and Dr. Coues (the further elucidator) have given most enthusiastic descriptions of its moving puwer and melody. When the skylark feels the impulse to sing, be rises from the bare prairie ridge with a peculiar bounding flight, like that of the pipit; up, in silence, higher and higher he goes, up, up, 100, 200, 300, 500 feet; then, feeling his spirits corre. spondingly werated, he spreads his wings and tail and pours forth the strains that are making him famous. The song at the beginning is much like that of the English Skylark, and the notes are uttered de. liberately but continnously, and soon increase in rapidity and force, till in a few seconds the climax is reached, after which they fade away in a veery-like strain, and then suddenly stop. While this was being sung the bird had floated downwards, and as soon as it is finished he proceeds, by the bounding flight, to regain his elevation and once more pour out his silvery strains.

Several times after a skylark had sung and returned to earth, with the headlong descent already described, I purposely flushed him, and at once he rose without further preamble, soberly remounted his imagi. nary 500-foot platform, and again sang his serenade from beginning to end. Thus on one occasion I called the same bird three times "before the curtain ;" to the fourth encore, however, he would not respond, and each subsequent t.me that he was disturbed he would fly off some 200 yards and again settle on the prairie. Once only have I observed this species singing his full song on the ground. 
ng to ond a int his songs. I began to 8; just as he his tail went th the bright. ngs, so that I is singer had ranked above

twenty times the ground; e of the com. ventriloqual in full song. are of its be, I could not little further roughout the lance that at high that as eye the tiny feet around. 1e discoverer) onthusiastic skylark feels ith a peculiar er and higher spirits correours forth the beginning is - uttered deity and force, ley fade away his was being is finished he nd once more

to earth, with hed him, and ted his imagi. beginning to times "before respond, and off some 200 observed this

\section{Galeoncoptes carolinendie. Catbird.}

Abundant summer resident of low thickets. Oommon in Red River region and westward along the boundary to Turtle Mountains; breeding (Oones). Winnipeg: Sunmer resident; abundant (Hiue). North to Lake Winnipeg (Ridgway). Ossowo: Common; breeding; 1885, first seen, one, on May 26 ; next seen, May 27 (Wagner). Oak Point: 1884, arrived April 30 (?); 1885, first seen, one, on May 14; next seen, one, on 15th; is common and breeds here (Small). Portage la Prairie: Common ; summer resident ; arrives about May 22 ; departs about September 15 (Nash). Carberry : Abundant; summer resident; breediug; all thickets from Oarberry to Birtle and north to Dark Mountain abundant; breeding; Long River (Thompson). Two Rivers: 1885, first seen, one, on May 25; next seen, one, on May 26; fairly common (Criddle). Oommon throughont the wooded country in the Northwest (Macoun). Shell River: 1885, first seen, one, male, on May 18; uext seen, four, on May 24; is common all summor and breeds here (Caloutt). Qu'Appelle : Common summer resident; breeds ; arrives about May 15 (Guernsey).

On June 22, 1882, I took the four eggs from the catbird nest found June 18; one measured $\frac{1}{8}$ by $\frac{15}{18}$ and is of a deep blue-green; the others are similar. The nest was made entirely of sticks and black fibrous roots, and was placed in the densest part of a willow thicket, thus giving us a pair of sooto birds building in a gloomy thicket a black nest to contain the brightest blue-green eggs that ever were laid 1

The month of June, 1884, was spent in traveling with my brother, "per cart." in the country between Carberry and Coté's Reserve, near Fort Pelly. Throughout the whole of this region the catbird is an abundant species, and I had ample opportunities for studying the song of this bird, for it seemed at much pains to render itself the most conspicuous of the feathered population, while at the same time it strove with equal diligence to remain unseen. Each night we slept in some thicket of willows, and each morning we were awakened by an incessant scolding from a vituperative catbird, who continued to skulk about and mew and squeal, until at length the evident miscarriage of his purpose to remain unseen warned him that his wisest course entailed a speedy departure.

249. Earporhynchue rufus. Brown Thrasher, or Thrush.

Common summer resideut of dry, partly open country. Pembina: Nesting (Cones). Winuipeg: Summer resident; tolerably common (Hine). On the flank of the Big Ridge, the Ciunamon Thrush (Turdus rufus) was noticed (Hine). Lake Winnipeg (Ridgway). Red River Valley : Summer resident; tolerably common (Hunter). Oak Point: 1884; arrived May 21 (Small). Tolerably common summer resident 
near Portage la Prairie; abundant near Winnipeg; arrives about the middle of May, departs late in September (Nash). On the Portage la Prairie trail, east of Fairview "The Cinnamon Thrush is not un. common among the sandy hills; we saw several during the day" (Hind, 1858).

Carberry : Common summer resident; breeding; Long River; Shoal Lake, west (Thompson). At Swan River; not common (Macoun). Shell River: 1885, first seen, one male, on May 23; next seen, two, on May 25; is common all summer and breeds here (Oalcutt).

250. Troglodytes aëdon azteous. Western House Wren. Common Wren.

Abundant summer resident in partly wood localities. Breeding rery abundantly at Pembina in June; taken at Mouse River in September (Coues). Winnepeg: Summer resident; tolerably common (Hine). Os. sowo: Common breeding; 1885, first seen, two, on May 18; next seen, May 19 ; becamo coinmon, May 20 (Wagner). Oak Point: 1884, arrived May 17; 1885, first secn, one, on May 17 ; next seen, one, on May 18; is common and breeds here (Small). Portage la Prairie: Common sum. mer resident; arrives about May 21; departs early in September (NasL). Carberry: A bundant summer resident; breeding; Duck Mountain breed. ing (Thompson). Manitoba House, June: Breeding; also at Waterhen River; frequent (Macoun). Shell lRiver: 1885, first seen, a pair, on May 17; afterward seen every day ; is common all summer, and breeds here (Calcutt). Qu'Appelle: Common summer resident; breeds; arrives May 12 (Guernsey).

On July 9, 1884, I found a nest of young wrens over a window of the ferry house on the Assiniboine. The old ones were laboring so inces. santly to furuish them with food that I timed their jonrueys to ascertain the amount of attention required by the nestlings. The parents re. turned ten times in fifteen minntes, sometimes bringing only one insect, but usually with their bill full of them. Twice during that time they carried out dung in their bills, dropping it some 20 yards from the nest. At this rate the old cnes would make not less than five huudred journeys each day. The time of observation was 6 o'clock in the evening. Nr. Kenuicott ascertained that a pair of wrens carrled to their youug about one thousand insects in a single day; but this is perhaps below the mark, for the pair I have just meutioned often bronght three or four insects at a time.

It is probable that two broods each season are raised by this species in Manitoba.

It will be seen that although this bird nsually nests in a hollow stump, it is rot averse to a different situation, provided only that it be a hole, and deep enough and narrow enough to exclude any but the owner. If the hole chance to be in the least a loose fit, his first care is to blockade the doorway with the largent twigs be can carry untll he has reduced it to his own idea of snugness; and I learned to accept it 
ves about the the Portage sh is not un. ing the day"

River ; Shoal on (Macoun). seen, two, on

mmou Wren.

Breeding very in September n (Hine). Os. 8 ; next seen, 1884 , arrived 8 , on May 18; Uommon sum. ember (Nash). untain breed. ) at Waterben pair, on May d breeds here ; arrives May

window of the ring so inces. is to ascertain 10 parents re. ly one insect, a at time they rom the nest. lred journeys vening. Mr. young about ps bolow the three or four

this species

in a bollow only that it any but the o first caro is arry until be to accept it as the infallible doorplate of a wren's homestead when a bundle of twigs was seen projecting from a cranny in somo decrepit-looking stump, a hollow rail, or a knot hole in an outhouse.

On one occasion I was told that a wren had built jis nest in the pocket of a coat hung ou the door of a ferryman's house on the Souris River. (Christy.)

My records of the neeting of this bird show that it is rather a late breeder here. In 1884 they are as follows: July 19, uest containing young well fledged; July 21, folind nest containing young half fledged ; Augnst 5, another nest containing young nearly fledged. These neste ware all built just under the top of the river bank. (Nash, in MSS.)

\section{Troglodytes hiemalis. Winter Wreu.}

Summer resident in the thick woods to the eastward. Is common in the wood country east of Winnipeg during the summer mouths (R. H. Hunter). Portage la Prairie: Rare visitor; on Mas 16, 1885, I believe I saw this species in the woods near here; thi bird was feeding on the ground, but when it saw me it disappeared in a large pile of old logs and brush, out of which my dogs could not drive it; on Octo. ber 29, 1886, I identifled it on the west bank of the Red River, about 5 miles south of Winuipeg (Nash).

\section{Ciatothorus atellaria. Short-billed Marsh Wren.}

Summer resident of erratic distribution found in sloughs. Rather plentiful at Pembina; undoubtedly breeding (Coues). Winnipeg: Sum. mer resident; rare (Hine). Red River Valley : Summer resident; rare (Hunter). Portage la Prairie : Rare; I have only taken it twice, Octo. ber 3,1884 , near here, and October 7,1886 , abont 7 miles south of Winnipeg (Nash). Carberry, south slope of Riding Mountain, north to near Coté's, abundant summer resident of the grassy (not the rushy) sloughs (Thompson). Qu'Appelle: Common summer resident; breeds ; arrives May 15 (Guerusey).

Soon after the 1st of May every little sedgy pool and slough in the Assiniboine Valiey, from Carberry to Pelly, is vocal with the merry chatter of this bird.

Its ordinary note is like two stones being struok together abont a dozen times in succession; the first strokes with a slight panse between those following, with rapidly reduced interval until the last are all run into each other. It may be auggested by the following syllubles: "Ohap - chap - chap - chap, chap, chap, chap p.p.p.r.r-r."

About the 6th or 7th of May it begins to sing a simple song, which uaturally divides itself into thrae parts or bars: First, the "chapper. ing" already described; second, in close connoction a rather musical refrain of equal length, somewhat like the first balf of the baywing's sunset soug, but without its richuess and with less of its power; ancl third, the "chappering" again from beginning to end. These call notes and songs may be heard on all sides for some time before a single 
wren is espied, for they creep and scramble about like mice in the tangled herbage along the sloughs. Many a time I bare marked one as it entered a small tussock and then, expecting to flush it, $I$ have gons over and kicked the tussock in vain; the bird had slipped out at the other side, and was probably watching me from behind a rushroot a vard or two removed.

When singing, it is usually seen clinging to the side of some tall swinging reed, with its tail bent back so as to almost touch its head, thus exhibiting in a most exaggerated manner a characteristic attitude of all the wrens.

The nest is a globular structure, and judging by the one or tro cases that I have observed is generally placed in a grass tuft. If there is any difference, I think the Short-billed selects a dryer situation for bis home than the Long-billed Marsh Wren.

253. Cistothorus palustris. Long-billed Marsh Wren.

Summer resident of marshes. Winnipeg: Summer resident; tolerably common (Hine). Have noticed it from Selkirk to the Souris, par. ticularly at Shoal Lake, north of Winnipeg, where they appear to be rery common (Hunter). Oak Point: 1884, arrived Niay 15 (Small). Portage la Prairie: 1884, common summer resident (Nash). Abundant; breeding; at Winnipeg; at Waterhen River (Macoun). Never found at Carberry, or in any part of the Upper Assiniboine, so far as I know (Thompson).

254. Certhia famillaris americana. Brown Creeper.

Very rare; snmmer resident of woodlands. North to Red River Settlement (Ridgwas). Winnipeg: Summer resident; rure (Hine).

255. Bitta carolinensis aculeata. Slender-billed Nuthatch.

Somewhat rare; summer resilent of woodlands; its distribution seems to be much the same as that of the oak ( $Q$. macrocarpa). Win. nipeg: Summer resident; rare (Hine). Portage la Pruirie: Common; chiefly in spring and fall (Nash). Oarberry: Summer resident (W. G. A. Brodie). Rare in the spruce lush south of Carberry ; seen in fall chiefly; Rat Portago in fall (Thompsou). Was not an ubundunt species, but I brought home one specimen taken at Curberry in summer, 1883 (Cliristy).

On Oetober 24, 1884, I was guirled in the woods to a nuthatch by the sound of his hammering, whleh wus so loud that I attributed it to the Hairy Woodpecker. I watched for a few seconcis and found that he was busiod "hatching" a hazlenut, which ho had fixed in a crevice of tho bark. Then I cume neer, wherenpon tho bird, fenring I should become troublesome, endeavored to take his nut and go elsewhere, but

it was

feet of

Comm large flo and disa sis acule On th I naw W below $\mathrm{z}$

I did 1 peg. (\$

I caI itoba; subspe

Ver: North dent ( in Ma: two 0 Winni toil).

Moch the sea making from $t]$ which neuts 1782.)

The 1 August aut on somo $t i$ Septen a party others this I near $P$ before

Re: strict Winn (Ken: (B. I Resid 
mice in the marked one ish it, I have lipped out at d a rushroot

of some tall puch its head, ristic attitude

one or two rass tuft. If pyer situation

n.

sident; toler. e Souris, yar. appear to be 15 (Small). Abundant; ever found at ar as I know

- Red River re (Hine).

itch.

distribntion arpa). Wine: Common; ident (W. G. ; seon in full duut species, ummer, 1883

nuthatch by ributed it to d found that in a crevice ing I should sewhere, but

it was so firmly fixed in the bark of the tree that I was within a few feet of him before it was extricated, and he flew off with it in his beak.

Common in opring aud autumn near Portage la Prairie, appearing in the spring in large flocks about the end of April ; in the autumn the broods come straggling back and dlsappoar as soon as cold weather setsin; these are in all probability S. carolinen. sis aculeata.

On the 13th of December, 1884, and from then to the 20th, in the Riding Mountains I saw White-bellied Nuthatches evers day; the weather was intensly cold, nearly $40^{\circ}$ below zero ; these were probably the typical form.

I did not see a single White-bellied Nuthatch of either variety in 1886 near Winnipeg. (Nash, in MSS.)

I can not concur that both forms of Sitta carolinensis are found in Manitoba; all that I have seen are vearer to aculeata than to the typical subspecies.-(E. E. T.)

\section{SItta canadensis. Red-breasterl Nuthatch.}

Very rare summer resident. Red River Settlement (D. Gunn). North to Lake Winnipeg (Ridgway). Winnipeg: Rare; summer resident (Hine). Portage la Prairie: Rare (Nash). Carberry: Once seen in May? (Thompson). In company with Black.cap Tit and Regulus ou two occasions on the 26th of September, 1857, not far west of Lake Winnipeg, on the Lower Saskatohewan, a specimen preserved (Blakiston).

Mochio a nak a sish. This bird is a species of the titmonse genus; seldom visits the seacoasts, but are very plenty about 300 miles inland in summer, where it breeds, making an elegant nest in a tree, lays fivo to ten eggs; fuels on berries and insects from the tree; at the approach of winter it retreats to a nore hospitable climate, which is contrary to the other tituouse, who are most numerous about the settlemeuts in a severe cold wivter. (Hutchins, MSS., Observations ou IIudson's Bay, 1782.)

The first I saw flew into my honse at Fort Ronge, near Winuipeg, nbout the 15th of August, 1886; some few days afterwarls 1 saw one in the wools uear the Red River, aud on the 1st of September auother birl eame into my houso and amused itoulf for some time by catchiug lies about the walis, regariless of the preseuce of my fiunlly. September 23 I saw another in the wools above meutioned, and on the 30th I saw a party ot three near the river; of these I shot one, and so tnue were they that the others did not fly or sliow the least alaru at the report of the gun. Shortly after this I saw nnother singlo one, the last of the senaon. None were ever seen by me near Portage In Prairie, or In fact auy where bitt in the woods on the Red River, us before mentiouod. (Nash, In MSS.)

\section{Parua atricapllius septentrtonalts. Long-tailed Chickadee.}

Resident; abunciant in wooded sections. The Manitoba bird is not strictly septentrionalis, but is nearer to that form than to atricapillus. Winnipeg: Resident; tolerably common (Hine). Lake Winnipeg (Kennicott). Winnipeg River: A female, that was about to lay hore?:? (B. IRoss). Ossowa: Common resident (Wagner). Portngo la Prairio: Resident, I believe; but although they are abundant luring antumn, 
winter, and spring, yet they disappear systeriously during the summer months; I saw them in December, in the Riding Mountains (Nash). Carberry : Oommon resident in the woods to the south and east: Rat Portage, abundant in fall (Thompson). Very common in Northwest Territory, along our route (Macoun). Shell River: 1885, winter visitor (Calcutt.) Qu'Appelle: Common permanent resident; breeds (Gueru. sey).

\section{Parus hudsonicus.. Hudsonian Chickadee.}

Fonnd only in the north and east among the great coniferous forests. Permanent resident; common in the coniferous woods in the northern and eastern parts of Red Kiver Valley (Hunter). In flocks around the Porcupine Mountains (Macoun). Seen and examined between Hudson Bay and Lake Winnipeg (on the Nelson River); did not find it be. tween Norway House and Fort Oarleton after leaving the thickly wooded country to the east of Lake Winnipeg.

\section{Regulus satrapa. Golden-crowned Kinglet or Wren.}

Very rare migrant; probably breeds. Winnipeg : Summer resident; rare; possibly breeding (Hine). Portage la Prairie: Very rare migraut; October, 19, 1886, I saw a flock of about fifteen near the junction of the Assiniboine with the Red River; they were very tame; these are all I ever saw in Manitoba (Nash). Carberry : November 5, 1884. While hunting in the sand hills to the south, to.day, I came across a flock of four Golden-crested Wrens; they were clambering about the tops of some low sipruce trees, and uttering their peculiar "streep, streep;" this was nearly three weeks after the ground was covered with suow; this was the only occasion in which I met with the species in the province (Thompson).

260. Regulus calendula. Rnby-crowned kinglet.

Tolerably commou migrant. Mouse River in September (Coues). Duferin: Arrived beiween April 15 and 20 (Dawson). Winnipeg : Summer resident; tolerably common (Hine). Portagela Prairie : Common spring and autumn visitor; arrives nbout 1 pril 20 , reappears about the middle of September, and departs at the end of the month; the Ruby.crown has a very pretty song; in spring its rolume is astonishing, when one considers the little body that produces it (Nash). Carberry : Common in spriug migration (Thnmpsou). Occasionally observed (between Nor. w if House and Fort Carleton in autumn); specimeus closely examined; Giii erus, not seeu (Blakiston).

On Nity 12, $: 883$, whilo hunting along by theslough, I beard a loud. rciced wrrhler singing a sonp. like pic piee pi-ee hecp.pi-che heep.pi che

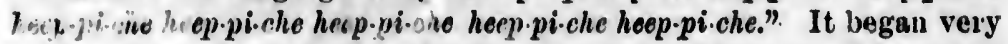
surt, let si on 1a:g out as loud and strong as a Cunary. 1 unanaged

date

on $\mathrm{M}$

Porta depa ward, mer $\mathbf{r}$ along Reser reside 
the summer ains (Nash). d east: Rat Northwest inter visitor eds (Guern.

cous forests. de northern around the sen Hudson $t$ find it be. the thickly

er resident; $\checkmark$ rare miir the juncame; these ber $5,1884$. tme across ring about ar "streep, as corerell the species

ues). Duf: Summer non spring the middle uby.crown when one Common ween Nor. oxamiued;

rd a loud. heep-pi che ogan very unanaged to shoot one, and was surprised to find it a Ruby-crowned Wren, for the volume of sound would have done credit to a much larger bird.

In its habits, as well as its food, this species closely resembles nuany of the wood warblers, so that it is difficult of identification when among the branches; but its peculiar nimbleness and its trick of playing and dashing after insects among the topmost twigs, together with its chicka-dee-like manner of clim ving about, will often cause its identity to be suspectel, if these ways do not entirely distinguish it from the Mniotiltidæ.

\section{Turdus fuscescens. Wilson's Thrush. Veery.}

Abundant summer resident of thickets. Observed only in vicinity of Pembina ; breeding in abundance during June (Coues). Red River Valley : Summer resident; tolerably common (Hunter). Selkirk and Red River (Gunn). Shoal Lake: May 20, 1887, seems to arrive on this . date (Christy). Oak Point : 1884, arrived May $17 ; 1885$, first seeu, one, on May 3; next seen on May 5; is common and breeds here (Small). Portage la Prairie: Abuudant summer resident; arrives April 23, departs at the end of September (Nash). Lake Manitoba and westward, nest found on the ground (Macoun). Carberry : Abunclant summer resident; breeling; noted in all the willow thickets from Carberry along the south slope of the Riding Mountain, and north to Cotés Reservation (Thompsou). Qu'Appelle: Tolerably common summer resident; arrives about May 20 (Guernsey).

On Juue 18, 1882, I heard again aud again, the first time for the season, a song that has been familiar for years. I had always attributed it to a thrush, but now was able to identify the birl more exactly as the Tawny Thrnsh, or Veery. The song is a high.pitched whistle, set rich and clear, with a rippling eadence like a little brook. It seems almost profane to represent this soft silvery tiv':ling by adopting uncouth syllables, yet I think the best idea of the mere articulation may be suggested by the syllables "Veery, veery, vep.y, veery," from which, no doubt, the singer got his name.

261a. Turdus fuscescens salfoloolus. Willow Thrush.

Taken on the Souris at tho boundary, in the fall migration, Sel mber 16, by Dr. Coues. Recorded as Turdus sucainsoni.

262. Turdus aliolie. Grsy.cheoked Thrush.

Migrant. OJmmon migrant at Winnipeg (Bine). Migrant at Carberry (Thompson).

263. Turdus ustulatus swainsond. Olive-backed Thrush.

Tolerably common summer resilent. I $1 \mathrm{~m}$ disposed to question all these records, as this bird is generally confounded with $T$. alicice (1: E. T). Wiunipeg: Summor resident (Hive). Portage la Prairie : Rare; 
summer resident; common in spring and autumn; arrives about April 27, re-appearing about September 15; departs early in October (Nash). Swan River and Moose Mountain: Breeding in rose thickets a few feet from the ground and in cornel bushes; eggs spotted (Maconn). Carberry : Summer resident; not very common; apparently breeding; Long River; Dnek Mountain? ('i'hompson). Shell River: 1885, first seen, a pair, on April 30; is common all summer and breeds here (Oalcutt).

\section{Turdus aonalaschke pallasii. Hermit Thrush.}

Common summer resident of woodlands. Winnipeg: Summer resident; abuudant (Hine). I have noticed them at Kildonan, Selkirk, Brandon, and Fort Qu'Appelle; at the latter place they were nesting first week in June (Hunter). Portage la Prairie: Common summer resident; aı rives about May 1; departs early in October (Nash). Lake Manitoba and west to Fort Pelly (Macoun). South slope of Riding Mountaiu on Little Saskatehewan, August 28, 1858 (Hind). Shell River: First seen, two males, on April 18; a transient visitor, passing north and not remaining any time (Calcutt). Observed at Cumberland Eouse on the 4th of October; I saw it several times, but had no gun (Blakiston).

265. Merula migratoria. American Robin.

Common summer resident in half open woods, ete.; breading. In abundance at Pumbina ; breeding; in Septem -2 , large numbers along Monse River (Cones). Dufferin: Arrived in 1874 between April 15 aud 20 (Dawson). Wiunipeg: Summer resideut; abundant (Hine). Red River Settlement, fourth week of April (Blakistol). Swamp Island : 1885 , first seen, about thirty, on April 27, after which it was common, and it breeds here; in fall, last seen October 7 ; 1886, first seen, ten, on April 18; bulk arrived next day (Plunkett). Ossowa: Com. moll; breeding; 1885, first seen, tive, ou April 18; uext seen, April 20; be ame common $A_{\text {pril }} 25$; last seeu, one, on. October 20 (Wagner). Oak Point: 1884, arrived, April 10; 1885, first seen, two, on April 8; next secu, April 9 ; atterwards common; breeds (Small). Portage la Prairie: Common; summer resident; arrives in April; my earliest spring record is April 3, 1885, when $I$ saw a small flock; the latest is April 20, the bulk having then arrived; they frequently remain until after snow has fallen, feeding on the wild grapes and high-bush cran. berries. The latest date I have is November 3, when I saw a large flock; the ground was then covered with snow (Nash). Abuudant everywhere throughout the Northwest (Maeoun). Carberry: Very abuudant in spring migration; common summer resident; breeding (Thoinpsous). Two Rivers : April 17, 1884; 1885; first seen, several, on April 16; next seen, April 17; became common $A$ pril 20; is pretty common and breeds here (Gridlle). Dalton: 1859, first seen, two, on April 12; became common on April 13; breeds here (Youmans). Bran. 
bout April er (Nash). a fow feet iii). Car. breeding; 1885 , first reeds here

amer resi. , Selkirk, re nesting n summer h). Lake of Riding d). Shell r, passing mberlaud a no gun

ding. In ers along April 15 t (Hine). Swamp ch it was irst seen, va: Com. April 20; Wagner). April 8; ortage la - earliest latest is ain until ish cran. a large buudant : Vory rreeding several, s pretty two, on Bran. don, April 20, 1882 (Tood). Shell River: 1885, first seen, two, on April 13; next seen, thirteen, on April 17; became common on April 24 ; male and female in flock; common all summer and breeds here (Calcuit). Qu'Appell's: Oommon summer resident; flocks of four or five about April 12 (Guernsey). Severu House, Trout Lake Station: The color is unusually bright in the specimens received (Murray).

On April 28,1882, drove to the spruce. brush ; the country seems flooded with rovins; the last mile of prairie, just before entering on the wooded and sano' hill region, was covered with an immense straggling flock. They wore to be seen chiefty ou the grouncl or making short flights. The gecieral movement of the flock was northward. There must have been several thousands of birds in it.

Un July 11, 1883, among the sand hills on the Portage Trail, I found a robin's nest; it was placed about 4 feet from the ground in a small isolated spruce, and contained three eggs which would have hatched within a week. This may have been a secoud brood.

Its song is first heard in the morning when the dawn is well adranced, the robin being more tardy to raise the matiu soug than mauy of his compeers. It is heard until the middle of the forenoon, then usually ceases until near sunset, when it recommences and coutinues until dusk. I have not yet noted this species singing by night. If when singing the bird be slightly sturtled by some noise close at hand, the lond cheery note is stopped, or at least altered, so that, although the sing goes on, it is very faint and sounds as though coming from a great distance, and a close inspection will show the bird's bill to be shut. This was first pointed out to me by Dr. Brodie, but I have noted the same habit in several other species.

The loud rolling notes will remind Europeans of the voices of the Song Thrush and Blackbird, but there is a terminal bar of frequent occurrence that recalls the metallic notes of our own Wood Thrushes and reminds us of their near kinship to the Red-breasted Fifer (Toronto, 1885).

I have several times noticed that a uest containing yot.ng robius was lined with an inuer coating of fibers, but ean not say that this was added after the hatching of the soung.

A friend informed me of a curious circumstance relative to a brood of this species. He had watched the old ones building in a silverbark or poplar, but shortly after the young were hatched he olserved that ine parents ceased to show themselves. After a little he climbed the tree and found in the nest the remains of the four young; nothing but the skins, all in shape with great staring eyes, but perfectly hollow and dried with the surr, while in and nbout them were hordes of ants, evi. dently the clevourers if not the destroyers of the callow brood.

\section{Blalia slalis. Bluebird. Blue Robin.}

Rare summer resident; chiefly about the large towns. Winnipeg: Rare summer visitor (Hine). Led River Valley: Summer resicleut; toierably common; noted a number of nests last year, 1884, inside city 
limits (Hunter). North to Lake Winnipeg (Ridgway). Oak Point: 1885 , first seen, one, on May 24; next seen May 25; is common and breeds here (Small). Portage la Prairie: Scarce; summer resident; a few pairs seen each summer; near Winnipeg quite common (Nash). Carberry : One record, a female with nest and eggs taken in the south sand hills by my brother, Dr. A. S. Thompson, June 8, 1886 (Thompson). In Minnesota: Abundant; breeds (Trippe).

May, 1884, Portage la Prairie: I have a single observation by Mr. C. W. Nash, which recorls the arrival of about forty bluebirds at this place at this time. They arrived in the gray down. Afterwards, in the day light, a second flock descended from the upper air and joined the first. Both Hocks were of both sexes. One inference from this is that the ring migration is performed at night. In the fall the flocks are cicen to be seen flying by day, at a considerable elevation, while from time may be heard their warbling note, which, though it sounded so cheery in the springtime, now seems but a melancholy rewinder that the time of the singing of the birds is past.

A recent arrival, but which seems likely to become abundant as it is increasing fast. The first I ever saw arrived iu a small flock just at daylight, May 29, 1884. They hovered about for a time and then pitched down uear my garden at Portage la Prairie. As this place is fortunaw'y not infested with those pests, the bird collectors, they remained, and two pairs bred uear me. These ouccesefully carried of their brouds.

May 22, 1885, moro of them arrived and brod in the town.

May 3, 1886, quite a large flock arrived and spread themselves all over the place.

Near Winnipeg they are also now quitecommon, but I can not say when they lirst appeared there. I saw noue in that distriot previous to 1885.

They depart early in October, my latest record being of Octo ber 3 (Nash, in MSS.)

A CHRONOLOGICAL LIST OF THE PRINCIPAL BOOKS AND ARTICLES CONSULTLD.

1744. Dobbe, Arthur. An account of the countries adjoining to Hudson's Bay, otc.: J. Robinson, London. 4to.

Chlefly geographical. One note on eagles quotid.

1795. Hearne, 8amnel. A journey from Prince of Wales Fort, in Hudson's Bay, to the Northern Ocean, 1769, '70, '71 and '72; 460 pp., London. 4 to. Birds, pp. 398-48.

1831. Ewainson, $\mathbf{W} \mathrm{m}$., and Bicharison, J., M. D. Fauna Boreali-Americana ; or the Zoölogy of the Northern parts of British America (etc). Part second. The Birds, by S. \& R., LXV1, pp. 524; pls. 24-73. Woodeuts, 41. London. 4to. The atandard work on the Birds of Br. N. America.

1859. Blakiston, T. Seraps from tho West. Newman's Zoologist, xvil, pp. 6318-6325, 6373-6376. Loudon. 8vo.

Notes of a journey from York Factory to Norway House and thence up the Saskatehewan to Fort Carleton.

1869. Hind, Henry Youle, I. A., F. R. 3. 8., oto. Report Progress. Preliminary and General Rep. Assiniboine and Sakatehewan Expl. Exped. (etc.) in 1858, xi1, 35, 192 pp. Toronto. 4to.

A standard work of exploratlon in Menitoba and adjolning reglone.

1878.

1880.

1001. 
k Point: ad breeds $t$; a few h). Caruth sand ompson).

by $\mathbf{M r}$. ebirds at erwards, ad joined $n$ this is he flocks n, while sounded erininder

asing fast. 84. They ortage la bird colanried of

o place. they first in MSS.)

ARTI-

lay, etc.:

y, to the

or the

1d. The

v. 4 to.

18-6325,

aokatche-

ary and in 1858 ,

1860. Find, I. Y., I. A., I. R. G. 8., oto. Narrativa of the Can. Red River Expl. Exped. of 1857, and of the Assiniboine and Sakatchewan Expl. Exped. of 1858. Two vols., 494 and 472 pp. London. 8 vo.

A second edition.

1861-'62. Blatiston, T. - On Birds collected and observed in the Interior of British North Amerio乡. The Ibis, III, 1861, pp. 314-320; Iv, 1862, pp. 3-10. London. 8vo.

An annotated list.

186s. Blakinton, T. On Birds of the Interior of British America. The Ibis, v, pp. 39-87, 121-155. Lor.don. 8vo.

1863. Hurray, Andrew. Contributions to the Nat. Hist. of the Hndson's Bas Territories. Aves : Part I (numerous specimens exhibited), 26th January, 1859. Proc. Roy. Physioal Soc. of Edin., vol. II, pp. 45-56.

Notes on 82 species, Inolnding a description of the new one (Bernicla leucoloema).

1868. Gunn, Donald. Notes of an Egging Expedition to Shoal Lake, west of Lake Winnipeg. Twenty-8econd Anu. Rep. Smithsoninn Inst. for 1867, pp. 427-432. Washington, D. C. 8vo.

Noter on Weatern Grebe, Earel Grebe, Rosy Gull, Tern, Peliean, Rnddy Duck, Snow Gooae, Red.head, Night Her on, and Meadow.lark, which $I$ have qnoted in full.

1870. Tach6, J. C. Sketch of the Nothwest of America, by Mgr. Tach6, Bp. of St. Boniface, 1868. Translated from the French by Capt. D. R. Canerou, R. A., 1870. Montreal. 8vo.

Seoond article, Birda, pp. 178-201 ; ennmerates two hnndred and thirty-five species.

1871. Trippe, T. x. Notes on the Birds of Minnesota. Proc. [Comm.] Eseex Inst., vi, pp. 113-119. Salem, Mase. 8vo.

1878. Couen, 펙ott. Notes on two little-known Birds of the United States, American Naturalist, vin, Nov., 1873, pp. 695-697. Centronyx bairdii and Neocorys spragueii.

1874. Cones, F. Birds of the Northwest: A handbook of the Ornithology of the region drained by the Missunri River and its tributaries. XII, 791 pp. Goverument Printing Offioe, Washington, D. C. 8vo.

An important work, treating obiefly of eynonymy, distribution, and hablte, with a mono. graph of the Laridew,

1874. Baird [8. F.], Brower [T. K.], and Bidgway [R.]. A History of North American Birds. Land Birds. 3 vols., 593 woodonts. Boston, Mass. 4to. Tho standard work on Iani Birds of North Ameriea.

1876. Dawnon, George Yercer, Assoc. R. S. M., F. G. S., etc. Geology and Resources of Forty-ninth Parallel: British North American Bonudary Conmissiou. Montreal. 8vo.

Chap. XI, par. 650, pp. 280, 281, dates of arrival at Dnfferin in 1874 of 36 species of birds. Also pp. 3, 4, 5, and 223, a brief description of the geological features of the province of Manitoba.

1878. Cones, 페iott. Field Notes on Bircls Observed in Dakota and Montara along the Forty-ninth Parallel daring the Seasons of 1873 and 1874. Bu!ll. $U$. $S$. Geol. and Geog. Surv. of Territories, vol. Iv, July 29, Art. xxv, No. 3. Government Printing Office, Wushington, D. C. 8vo.

A ralnabie oontribntion of fleld notes continuaily cited and quoted in the foregoing.

1880. Bell, Robert, M.D., F.G.S., C.E., eto. A List of Birds from the regiun between Norway Honse and the Forts Churchill and York. Geol. Sw'v., Can., 1879, App. vi, pp. 670-70o. Montreal. 8vo. An annotated list of 65 spenles.

1881. [Green, Bamuel.] (Letter on nesting of Blue Heron in Manitoba by "Bird's Tail.") Canadian Sportoman and Naturalist, vol. 1, No. 2, February 15, p. 13. Montreal. 8 ro.

Desoription of an immense heronry quoted in fall by me.

1081. Irooun, John, X. A, F.I.8., oto. Ornithulogioal notes. Ann. Rep. Dept. Inter. for the yoar ending Deoembur 31, 1880, pp. 23-28. Ottawa. 8vo. An annotated list of 100 apecles observed in Northwestern Canada. 
1882. Iacoun, Joh's, M. A., F. I. 8., to. Manitoba and the great Northweat; pp. 687. Guelph, Ontario. 8vo.

Chap. XXI, pp. 354-373. " Biris of tha Northwest," ennmerates 235 species.

1882. Bell, Bobert, M. D., L. L. D., F. G. 8. Notes on the Birds of Hudson's Bay. Proo. Roy. Soc. Can., seo. Iv, art. v1, pp. 49-54. Montreal. 4 to. Rnnuing commentary on 68 species.

1883. [Thompson, Ernest E.] Pediocetes phasianellus, or Prairie Chioken; by. "Ernest E. T. Seton." Can. Journal, vol. 1. pp. 405-412, Toronto, Ont., February. 8vo. An original biography.

1883. Brodie, Wm. George $\Delta$. Notes on the Nat. Hist. of Manitoba. Can. Sportoman and Naturalist, vol. I1I, No. 4, pp. 221-224. Montreal. 8 vo.

A runing commentary on 65 specieg.

1884. [Thompson, Emest E.] The Prairie Chicken, or Sharp-tailed Grouse; by " Erncest E. T. Seton." Rep. Dep. Agriculture, Prov. Manitoba, for ¿̇83, pp. 483-486. Winnipeg. 8vo.

A reprint from tho Case Jonrnal of Fohruary 1, 1883.

1884. Bell, Robert, K. D., I. D., F. G. 8., oto. Notes on the Birds of Hudson's Bay. Rep. Dep. Agr., Prov. Manitoba, for 1883, pp. 487-490. Winnipeg. 8vo.

A reprint from the Proc. Roy. Suc. Canada, as above cited.

1884. [Thompson, Ernent $\mathbf{\Sigma}$. ] Nest and liabits of the Conneotiont Warbler (Oporornis agilis); by "Ernest E. T. Seton." The Auk, vol, 1, April, pp. 192, 193. Boston, Mass, 8vo.

Deecribing the first anthentio nest and egge.

1884. [Thompson, Emest E.] The Prairio Chicken [Pediocretes]. " - Hints on rearing and domestication; by "Ernest E. T. Seton." Trane. Man. Hist. Sci. Soc., No. 14, pp. 13-18. Winnipeg. 8vo.

A life-history with very full account of the growth of the young, etc. This was also printed in fuil in the Winnipeg Free Press of a previous date.

1884. Baird [8. F.], Brewer [T. M.], Bldgway [R.] 'The Water Birds of North America 2 vols. Boston, Mass. 4 to.

This, with the Land Birds, 1874, oompietes the Blrds of Americs, the standard work on the enbject.

1885. [Thompwon, Ernest E.] Notes on Manitoban Birds ; by "Ernest E. T. Seton." The Auk, vol. 11, July, pp. 267-271. Boston, Mass. ovo.

1885. [Thompeon, Ernest E.] Nest and Egge of the Philadelphia Vireo; by " Ernest E. T. Seton." The Auk, vol. II, July, pp. 305, 306. Boston, Mass. 8vo. Describing the flist authentio nest and egge of the species.

1885. [Thompeon, Ernest E.] The Western Grebo in Manitoba; by "Ernest E. T. Seton." The Auk, vol. II, Jnly, p. 314. Boston, Mass. 8vo.

1885. [Thompson, Ernest 2.] Manitoban Notes; by "Ernest E. T. Seton." The Auk vol. II, Jan., pp. 21-24. Boston, Mass. 8vo.

1885. [Thompwon, Erneat E.] The Swallow-tailed Flyeatcher in Manitoba and at York Factory; loy "Eruest E. T. Seton." The Auk, vol, II, April, p. 218. Boston, Mass. 8vo.

1885. Chrity, Miller. Notes on the Birds of Manitoba. The Zoillogist, 3d series, vol. IX, No. 100, April, pp. 121-133. London. 8vo.

1885. Wood, T. B. "Notes on the Zoölogy of Manitoba ;" communicated by T. H. Nelson. The Zoölogist, 3d series, vol. 1x, No. 102, June, pp. 224-227; No. 103, Jnly, pp. 241-248. London, 8vo.

1885. Chriaty, Millor. Manitoba described. " Farming, olimate, oport, natural history, and fnture prospect of the conntry ; $208 \mathrm{pp}$. London. 8vo.

Chspter II, ou the action of prairle fires, argues that the prairiee were deforested by run. ning fires. Chaptor xin, sport and uatural hiajory, general remarks.

1885. Christy, villor. Notee on the Birds of Manitoba. (Reprinted from The Zoologist; revised for the Monthly.) Can. Sol. Monthly, vol. III, No, 7, July, pp. 92-94; No. 8, August, pp. 105-113. Kentville, Nova Scotia. 8vo,

$\Delta$ roprint from the Zobiogist, with siight slterations. 
1888. [Thompeon, Ernest E.] The Birds of Western Manitoba ; by "Ernesi E. T. S.эton." The Auk, vol. III, April, pp. 145-156; July, pp. 320-329 ; Oct., p. 453. New York. 8vo.

An annotater liat of 258 species.

1888. Tyrrell, J. B., B. A, F. G. 8., oto. Notes to accompany a preliminary map of the Duck and Riding Mountains in Northwestern Manitoba. Geol. and Nat. Hist. Surrey of Canada. Part W., Ann. Rep., 1857. Montreal. 8vo.

Contains matter reforring to distribntion of timber, oto., used in preparing the maps.

1888. Cooke, W. W. Report on Gird Migration in the Mississippi Valley in the jears 1884 and 1885. U. S. Dep. of Agric., Bulletin No. 2, 313 pp. Gov't Printing Office, Washiugton, D. C. 8vo.

1888. Thomperon, Ernest $\mathrm{E}$. The Song of the Prairie Lark. American Magazine, April, pp. 717-720. New York. 8vo.

Popnlar article on habits, with musical notation of song and two woodouts. The article is herewith reprodnced with sllght alterations.

1890. 8haws, Wm., F. R. G. 8. Phillips's Imperial Atlas of the World. Gen. Philips \& Sons, London. Fol.

Charts Nos. 67 and 60 ased in preparing my uwn maps.

\section{A LIST OF THE MANUSCRIPTS USED IN COMPLETING THE FORE-} GOING NOTES.

1788. Futchin,, T. Observations on Hudson's Bay, 651 pp.; pp. $45-180$ treats of birds.

An interesting unpnblished manuscript volume in the library of tho Hndson's Bay Company at London, with marginal annotations by Pennant. The anthor was for twenty-five years in the employ of the Hudson's Bay Company. There is no date or title page to the volume, but the last date mentioned is July 10, 1782, and it seems safe to conclude that it was issued about this date, from the fact that Pennant, in his second volnme of Arctio Zoölogy (p. 2i2), published in 1785, refers to Mr. Hutchins's manuscript as though it had just reached him in a complete state.

1879-81. Yacoun, Prof. John. Observations on the birds observed in western Manitoba during these three sfasons, specially revised and corrected for E. E. Thompson.

1882-83-84-86-86-87. Thompeon, Ement E. Ornithological Journal, made chiefly at Carborry in the years named, herein extensively quoted.

1883-84. Thompson, Arthur 8., Z. D. Notes on the arrival of birds at Winnipeg and Carberry in the above seasons; prepared for E. E. Thompson.

1883-84. Biohardeon, George. Notes on the arrival of birds at Carberry in the above seasons; prepared for E. E. Thompson.

1884-'85. Jash, C. W. Observations on the birds of Portage la Prairie and vicinity, during these two seasons; commnnicated to the A. O. U. committee on bird migration.

1884-86. Criddle, Perey. Observations on the birds of Two - Rivers and vicinity, during these two seasons; commanicated to the A. O. U. committee on bird migration.

1884-38. Cuerneey, Ceorgo F. Observations on the birds of Qu'Appelie and vicinity; communicated to E. E. Thompson at various times in the seasons mentioned.

1884-95. 8mall, A. T. Observations on the birds of Oak Point, Manitoba, during the above two seasons; communicsted to the A. O. U. committes on bird migration.

1885. Culontt, 2. Observations on the birds of Shell River, Manitoba ; communicated to the A. O. U. committeo on bird migration. 


$$
\rightarrow
$$



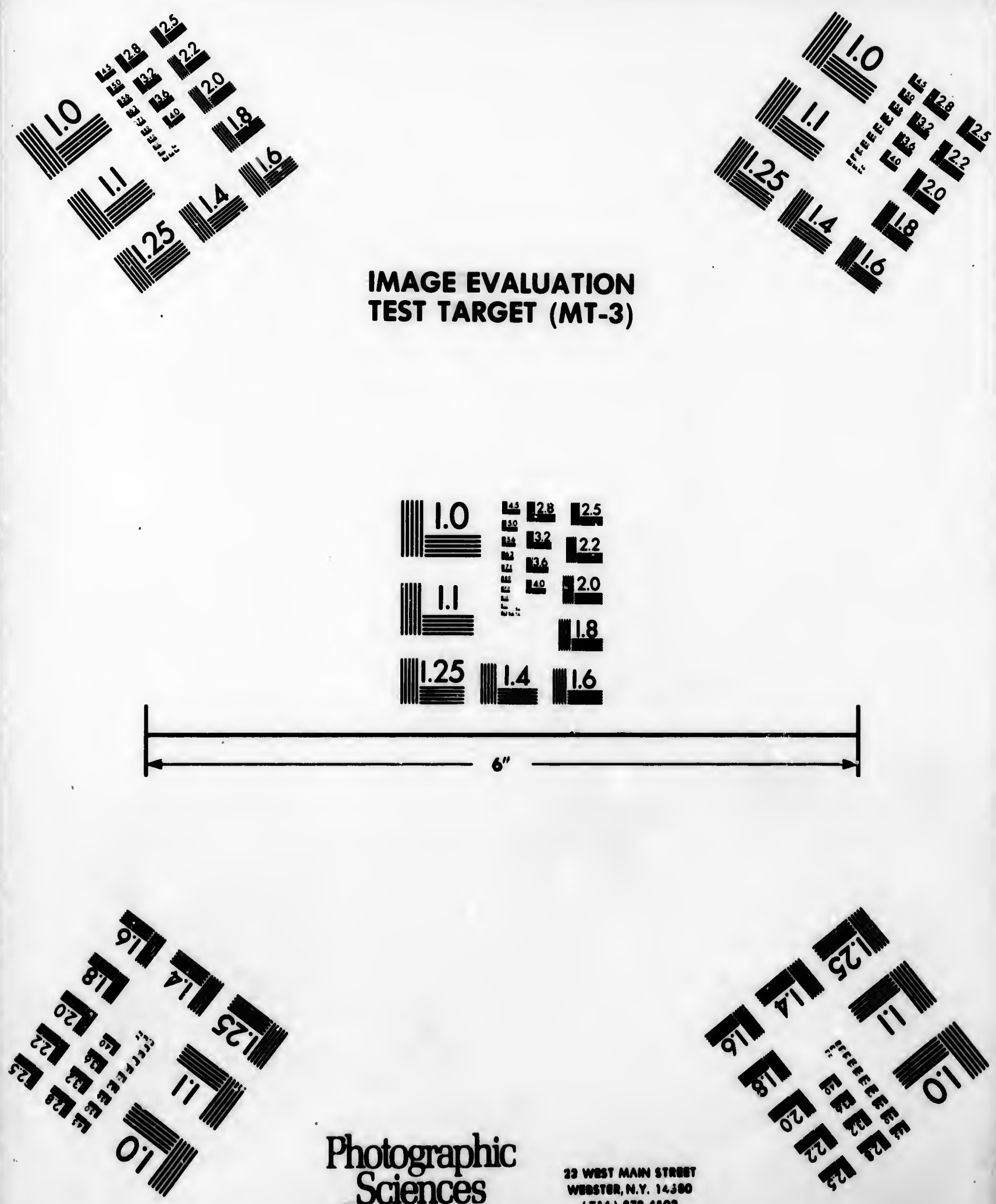

Photographic Sciences Corporation
22 West maw steen Whaster, N.Y. 1 ajece (716) 072-4803

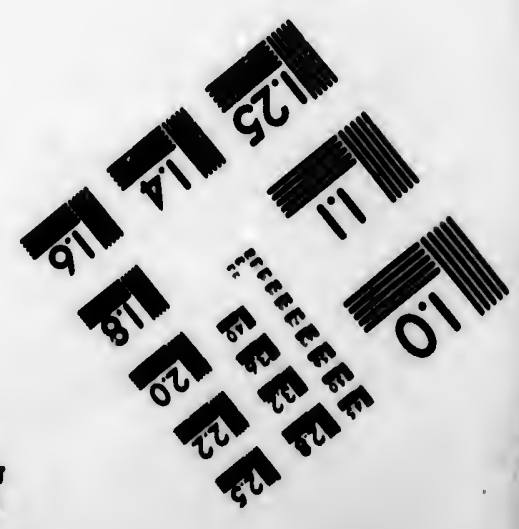


1885. Tonmana, Iottie. Obsersations on the birds of Dalton, Manitoba, and vioinity ; com unuicated to the A. O. U. committee on bird migration.

1385. Fnnter, Richard H. Annotated list of the birds of Red River Valley; prepared for $\mathbf{E}$. $E$. Thompeon.

1885. Wagmer, $\mathbf{F}$. O'jservatione on the birds of the vicinity of Oesowa, Manitoba; communicated to the A. O. U. committee on bird migration.

1885-'86. Plunkett. Observations of the birds of \$wampy or Berens Island, Lake Winnipeg, for the above seasons; communicated to the A. O. U. committee on bird migration.

1890. Hine, William. Observations on the birds of the vicinity of Winnipeg; prepared for E. E. Thompson, in March, 1890.

1890. Nash, C. W. Annotated list of the birds of the vioinity of Portage la Prairie, Manitoba; prepared for E. E. Thompson, May, 1890.

\section{INDEX OF BLRDS OF MANITOBA.}

Acadian Flyeatcher, 561 .

Lesnthis hornomanitexilipea,586.

Acanthis linaria, 688.

Aocipiter utrioapiline, 527.

Accipiter oooperi, 627.

Acolpiter velox, 527.

Actitie meoniaria 505 .

ASchmophorna ocoilentalis, 403.

Exgialitis melode, 507.

Aggialtia semipalmata, 507.

Asgialitls rocifera, 606 .

A gelains phceniceua, 572.

A.Ix aponaa, 480.

Amerioan Avocet, 497.

American Bittera, 488,

Amerioan Black Bcoter, 484

Amerlean Coot, 493

American Crovebill, 585.

Amorican Crow, 685.

Amerionn Fared Grobe, 104

Amcrioan Goldfineh, 586 .

Ameriean Golden Plover, 804.

Amerlean Golden-oye, 182.

A merlcan Gosherk, 627.

Anuerican Hawk Owi, 546.

Amorican Ferriag G all, 468.

American Long-cared Owl, 339.

American Magpio, 605.

$\Delta$ merloan Mergancer, 474.

Amerlean Oaprey, 697.

Ameriena Plpit, 625.

Amerloan Rodatart, 624.

Amorican Robla, 094 .

Ameriean Rough logged Hawk, 833.

Amerionn Scanp Duok, 481.

American Bparrow Hawk, 687.

Ameriasn Threotood Wood. peoker, 860.

Amerioan While-ironted Coome, 498.

American White Peliean, 478.

Amerioan Woodeook, tod

Ammodraman bolrdil, 088.

Ammodramne lecontol, Bes.

Ammodramen asod wichende al. andinat, ox
Ampelis cedrornm, 612.

A mpelis garrulus, 611.

Anas americana, 476.

Anas bosohas, 174.

Anas earolinenais, 477.

Ansa ojanoptere, 478.

Anas discors, 478.

Anas obacnra, 476

Anna atrepera, 476.

Anaer albifrons gambell, 486.

Anthns pensil vanions, 625.

Anthus opragnell, 025.

Antrostomus voolforans, 553.

Aquils chryostos, 633.

Arctlo Forned Owl, 545.

Arctio Throotoed Wood. pecker, 840.

Arotlo Tawhee, 607.

Arehibuteo ferrnglneus, $\mathbf{5 3 3}$.

A. lagopus asnotl-Johannie, 538.

$\Delta$ rien berodian, 489.

Arien virescens, 490.

Arenarla interpres, 507.

Aahy-nape, 001 .

Anto soolpltrinue, 840 .

Aalo wllsonienne, 639.

Aythya nfinite, 488.

Aythya amerieane, 180.

Ay thy collaria, 482.

Aythys marlla nearetios, 481.

Arthro vallieneria 4sl.

Bald Eagle, 638.

Balilpate, 476.

Raird' Sandplper, 600.

Balnd'n Bparrow, BO5.

Bdlimore Oriole, 860.

Barred Owl, M1.

Bartramis longloanda, 608.

Bartramian Badpiper, 208

Bank 8wallow, 611.

Jarn 8wallow, 610.

Barrow'a Colden-eje, 483. Bar wing, 602.

Bay-breated Tarbler, 610. Bolted Kingther, 547.

Bls Blac.bll, 4 t.

Bir Itolldiver, 4 .
Biroh Partridize, 508.

Black-and-white Warbler, 616.

Black-bollied Plover, 606.

Black-bellled Cnokoo, 547.

Blsok-breasted Longepnr, 501.

Blackbnraian Warbler, $\theta 10$.

Black-hend, 481.

Black-heart, 501.

Black-oapyed Wyontohor, 624.

Black-crowned Night Heron, 102.

Black Dack, 476.

Black Orrfalcon, 684.

Black.poll Wnrbler, 610.

Bleck Torn, 470.

Black-throated Ioon, 108

Binebiru, 635.

Blne Goose, 485.

Blno-beaded Blaokblrd, 581.

Blue-hemiled Vireo, 610 .

Blno Jay, 505.

Blue Robin, 635.

Blne.winged Teal, 478,

Bohemian Wax.wing, 011.

Bonsparto's Gall, 40 .

Bonsas umbollas togate, 608.

Bonses nmbellus nmbolloldes 600.

Botsurue exilla, 488.

Botenrua lontiglnoous, 488.

Brant 497.

Brants boralola 487.

Brante canadouala 483.

Brantacsnadonalo hntohinell, 488

Brewer' Blaokblrd, 84t.

Broed-winged Fints, 692.

Bronsed Graokle, 88.

Brown Creeper, 90.

Brown Thewher, 627.

Brown Thrubh, 6e7.

Bubo virglaleane srotlous BA.

Babo virgininane exbarotione 84.

Butivlo Bird, 608.

Bnfl brenated Sandpipor, Cus

Bunfe.hesd, 183.

Bullet Bawr, and

Bates borellic as?

Chlck

Chisu

Chipp

Choni

Chort 
and vioinity;

ley; prepared

a, Manitoba ;

Island, Lake

U. committee

innipeg; pro-

zo la Prairio,

Bnteo latiseimne, 632.

Buteo lineatus, 529.

Buteo ewainsonl, 529.

Calamospiza melanoeorys, 608.

Calcarius lapponicus, 688.

Caloarlus ornatns, 891

Calcariuo plotus, 381.

Cailidis arens: $i a, 501$.

Canads Gooso, 486.

Canada Jas, 566.

Canadian Rnffeci Gronse, 508

Canalian Warbler, 624.

Canvas.back, 481.

Capo May Warhler, 617.

Carpodacue purpureus, 585.

Catbird; 627.

Cathartes anra, 523.

Cedar Wax. wing, 012.

Ceophlone pileatus, 350.

Cepphu 3 mandti, 68.

Certhis familliarioamericana, 630.

Ceryle aloyon, 547.

Chetura pelagica, 556.

Charadrins dominlone, 600.

Charadrius squatarola, 506.

Charitonetta albeola, 483.

Chelidon erythrogaster, 610.

Chen ccerulesceus, 485.

Chen hyperborea, 485.

Cherry Bird, 012

Chestnut-collared Longapar, 391.

Chestnut-sided Warbler, 619

Chlcken Hawk, 327.

Chlinney Swifr, B56.

Chipping Sparrow, 000.

Chondestes grammacus, 597.

Chordelles virginlanus sennettl, 354.

Clunsmon Teal, 478.

Circus hudsontous, 524.

Cistothorus palustrie, 630.

Cistothorus steliaris, 629.

Clangula hyemalis, $\mathbf{4 8 3}$.

Clay-colored Sparrow, 801.

Ciur Swallow, 609.

Clivicoln riparla, 611.

Cock of the Woorle, 550.

Cocoszus erythrophthalmna, 547.

Coceothranates veapertinus, 384.

Colaptes auratus, 651.

Colsmbus anritua, 165.

Colymbua holbr vili, 165.

Colymbue ulgrioolile callfornt. can, 106.

Common Henhamk, 829.

Common Rall, toL.

Common Shrike, 618.

Common Snipe, 408.

Common Torn, 100.

Common Wren, 628.

Connectient Warbler, 021.

Cooper'a Hawk, 627.

Contopus borealla, 860 .

Contopne richardeoull, $B 60$.

Conlopno virena, 860.

Corrus amerlounus, 608 .
Corvns corax prinoipalia, 667.

Cowbird, 571.

Coween, 483.

Creeper, 616.

Crented Ylycatcher, 559.

Crow Dack, 472.

Crow Blackbird, 382.

Cyanocitta criatate, 565.

Dabohick, 167.

Daflis acuts, 470.

Dendrsgapus c8nadensis, 507.

Dendroica æativa, 617.

Dendro:ca esstanes, 619.

Dendroica blackburnix, 610.

Dendroles coronsta, 618.

Dendroica maculoss, 618.

Dendroice palmarum, 020.

Dendroica pensyiranica, 019.

Dendroles strista, 619.

Dendroica tigrina, 617.

Denilroien vigorsil, 320.

Doliohonyx orgzirurus albinn oha, 570.

Donble.crested Cormurant, 472.

Downy Woodpecker, 54 \%

Dryobaten pubescens, 340

Dryobates villosus lencomelas, 348.

Duck Hawk, 535.

Dusky Duok, 476.

Eave Swallow, 609.

Ectopistes migratorins, 322.

Elanoldes forficatus, 524

Fmpildonax acadious, 501.

Empldonax flaviventris, 381

Empidonax minlman, 361.

Enuplionax pusillus trailli, 501.

Ereunctea pusillus, 501.

Erismatura rublde, 484.

Evening Grosbeak, 504.

Falco oolnmbarias, 336.

Falco peregrinus anatnm, 835.

Faloo richarlsonil, 537.

Falco rusticolus obsoletus, 534.

Falen sparveriua, B37.

Ferruginoun Rough.leg, 533,

Fish Duck, 474.

Fish Ifawk, 537.

Fleld Bparrow, 003.

Flicker, 551

Fiying Sheep, 491.

Forater's Tern, 168.

Fox Bparrow, 006.

Franklin's Gull, 400.

Fullon americana, 405.

Gad wall, 676.

Gulronoopter carolinenuis, 087.

Galitnapo del leata, 408.

Geothlypia axllis, 681.

Geotblypla philedelphia, 622.

Qoothlypis trioban, 623.

Glanolonetta o n $\mathrm{gu}$ In a morl. Oanas, 482.

Glauolonette ialandion, 403

Golden.orownell Kinglet, 032.
Golden Eagle, 533.

Gray Duok, 478.

Gray Ruffed Gronse, 600.

Great Blne Heron, 489.

Great Gray Owl, 541

Greater Yellow.lege, 602.

Greon Heron, 480.

Green-winged Teal, 477.

Grus americens, 401.

Grno mexicana, 401.

Gray-checked Thrugh, 633 .

Habla Ludoviciana, 607.

Hal iæetus leucocephalue, 633.

IItarrier, 524.

Harris's Sparrow, 597.

IIarlequin Dack, 484.

Harporhynohus rnfns, 627.

Ielmluthophils celata, 616.

Heiminthophils peregrina, 616 .

Hermit Thrusb, 634 .

Highbolder, $\mathbf{5 5 1 .}$

Histrionioua histrionicne, 184

Ilosry Red.poll, 588.

Hooled Merganser, 474.

Holbill' ' frebe, 165,

Horned Grebe, 405.

House Swallow, 600 .

Hudeonian Chiokailee, 632.

II udsonisn Godwit, 302.

IIutching": Goose, 487.

Hytrochelidon nigra snrinamen. sis, 470.

Icterne galbula, 580.

Ioterus spurlus, $\mathbf{8 8 0 .}$

Intermediate Sparrow, 308.

Junco hyemalis, 603.

Jnnoo hyeinalis ohufoldti, 604.

Killdeer, 300.

Klngbird, 567.

KIng Rail, 404

Knot, 500 .

Lagopna lagopne, 814.

Lonius borealla, 012.

Lanlus lulovioianun exenbitorl. les, 618.

Lark Bunting, 008.

Lark Sparrow, 897.

Laras argentatus smithoonl. Bnue, 468.

Larus delarrarensla, 468.

Larus Annklinl, 469.

Larus philudolphie, 400.

Langhing Goose, 488.

I.apland Longmpur, 588.

Least Bittern, 180.

Least Flycatcher, 501.

Least Sand pjper, 601.

Loconte's Sparrow, 696.

Leaser Dnck, 192.

Limose feloe, 601

Limosa hemastion, 602.

Lincoln's Sparrow, 005.

Little Blue.bill, $40 \%$.

Loon, 467.

Long-bllled Curler, 606.

Louk. Lilled Dowitohor, 600. 
Long-billed Marsh Wron, 630. Long-tailed Chickadee, 631.

Luphoilytes cucullatns, 174.

Loria curvirostra minor, 685.

Loxis leueoptera, 686.

Macrorhampne scolopecene, 500.

Magnolia Warbler, 618.

Mallard, 474.

Mandt's Guillemot, 468

Marbled Godwit, 501.

Marsh Blue-bill, 482.

Marsh Hawk, 524.

Marsh Tarn, 470

Marsh Owl, 540.

Maryland Yellowthroat, 823.

Ml.lanerpesersthrocephalus, 551.

Melospiza fasolata, 604.

Mlolospiza georglana, 605.

Melospiza lincolni, 606.

Merganeer americanus, 474.

Morganeer serrator, 174.

Merula migratoria, 034.

Micropalama himantopus, 300.

Milvnlug forficatus, 557.

Missouri Skylark, 625.

Mniottita varia, 610

Molothrue ater, 571.

Mourning Dove, 523.

Mourning Warbler, 622.

Myiarchus crinitue, 350.

Myrtle Warbler, 618.

Nash villo Warbler, 610

Night.hawk, 554.

Northern Hairy Woodpecker, 548.

Northern Phalarope, 407.

No1 thern Raven, 507.

Northern Sharp-talled Grouse, b76.

Northern Shrike, 012.

Numeniue longirostris, 305 .

Nyctala acedics, 542 .

Nyctea nyctea, 546.

Nyctlcorax nyoticorax nævine, 401.

Nyctala tongmaimi riohardsoni, 642.

Olienia americana, 484

Oldemia deginadl, 484

Oldemla perepleillata, 484.

Old Squaw, 483,

Olor bueoinator, 187.

Olor colnmbianne, 187.

Ollro.becked Thrush, 633.

Olire-uided Flyontcher, 600.

Orange-orowned Warbler, 616.

Otocoris alpeatria, 645.

Otocuris alpestris pralloole, 602.

Orenblrd, 620.

Orchard Ortole, 6en

Pulm Warbler, 62.

Palnted Longeor, 601.

Iandion balliotua carolleonaia, 638

Partridge, 600.

Paran atrloapillo neptentrlon. alis, 682.

Parne budeonlone, 692.
Passerella lllaca, 606.

Pediocretes phanianelius, 516.

Pediocrter phasianelius cam. pestro, 516.

Pectoral Sandpiper, 500.

Pelecanne erythrorbynohos, 473.

Peregrine Faloon, 635.

Perisoreus canadenaib, 566.

Petrochelidon lunifrona, 600.

Pewee, 660.

Phalacrocorax dilophne, 472.

Pnalaropus lobatue, 407.

Phalarcpue tricolor, 497.

Philohela minor, 498.

Philadelpbia vireo, 615.

Phabe, 560.

Picoldes americanua, 550.

Picoldes arotious, 349.

Pica pics budsonica, 565.

Pled-billed Grobe, 187.

Pigenn Rawk, 536.

Plleated Woodpecker, 650.

Pino Grosbeak, 584

Piue Linnot, 587.

Pine Siakin, 587.

Pine Warbler, 020

Pinicola onucleator, 684.

Pintail, 178.

Pipilo erythrophthalmus, 607.

Pipilo maculatus arcticns, 607.

Piping Plovor, 507.

Pirange erythromelas, 608.

Pinuatod Grouse, 514.

Piectrophenax nivalis, 687.

Poocates gramineus confinis, 602.

Podil subus podiceps, 107.

Porzaua carolina, 479.

Porzana noveloracenele, 475.

Prairio Chicken, 516.

Prairio Hen, 514.

Prairle Horned Lark, 873.

Prairio Lark, 573.

Prairie Plover, 803.

Prairie Bhore Lark, 602.

Progne suble, 008.

Parple Fluch, 685.

Purple Miartin, 008

Qually, 603.

Qulacalus qnieonla meneus, 682

Italius eleguns, 494.

Rallue virginlenue, $40 \mathrm{~L}$

Reourvirnetra amoricana.

Rod-backed sendpipor, BO1.

Red-ejed Vireo, 614.

Red-breasted Merganser, 474.

Red-breanted Nuthatoh, 031.

Red breasted Salpe, 600 .

Rod Crosobili, 5 ses.

Red-hesd, 480.

Red-hoaded Woodpecker, 651.

Red-neoked Grobe, 463.

Red.poli, 580.

Red-shouldored $\mathbf{H} n \mathbf{n}, 529$.

Rod-talled Barrk, 628.

Rod.throated Unmming Bird, 357.

Red-thronted Lonn, 468.

Red.riaged Blaokblrd, 372.
Rod-poll Warbler, 620.

Regolus calendula, 032

Regulus eatrapa, 032.

Riohardeon's Merjin, 537.

Riohardeou's Owi, 542 .

Richardeon's Powee, 560.

Ring-billed Gail, 468.

Ring-nock, 507.

Ring-nceked Duck, 482

Robin Saipe, 500,

Kose-breasted Grosbeak, 607.

Rosy Gull, 400.

Rusty Black bird, 681 .

Ruby-crow ned Kinglet, 632.

Rudds Duck, 632.

Sanderling, 601.

Bandlill Crane, 49l.

Sand Martin, 611.

Satin Bird, 681

Sayornis phoebe, 890.

Saw.whet Owl, 572.

Scarlet Tanager, 608.

Solssor-talled Flycatcher, 557.

Seolecophagas carolinus, 681.

scolecophagan eyanocephalus, 681.

Sen Swallow, 460.

Seinrus novehoracensio, 621.

Semipaimated Plover, 507.

Semipalmated Sandpiper, 601.

Setopliaga ruticilla, 624.

Shas p-ghinned Ha7k, 627.

Sheldrake, 474.

Shore Lark, 564

Short-billed Marsh Wren, 020.

Short-eared Owl, 510.

Shoveler, 170.

Sbufeldt'a Junoo, 604.

Sialia sialla, 635.

Sitta canailenais, 631.

Sitta carolinensie, 633

Slato-colored Junco, 608 .

Sleader-bilied Nuthatch, 630.

Smith'e Longepur, $\mathbf{6 0 1 .}$

Snow Bird, 887.

Snow Bunting, 587.

Snow Flake, 687.

Snow Goose, 198.

Snows Owl, Wus.

Soldier Blackblrd, 672.

Solitary Sandplper, Bas.

Song Sparrow, 604.

Sorn, 494

Spatule clspeata, 470.

Sp: ,kle-belis, 486.

Spiryraplou varina, 630.

Splder Blrd, 617.

Sploes pinus, 507.

Spleus triatle, 60.

Bpisella montleole, 600.

Spisolls palllds, 601.

Spleolle pusilie, 608 .

Aplselle eooialis, 600.

spoonblli, 470.

Spotted Sandplper, 603.

Spragao's Pipit, 62a.

Spruce Partrldso, 607.
Sterna

Sterna

Stilt Sa

Sturnel

Surf D

Surf Se

Surnila

Swains

Swallo

Swallo

Swamp

Sีj।van

Sylvan

Sympli

Szrniu

Tacby

Tenne:

Tillark

Totanu

Totan

Totanu

Towee,

Traill's

Tree D

Tree S

Tree \&

Tringe

Tringa

Tringe

Triuga

Tringa

Tringa

Trochi

Troglor

Trogio

Trump

Turdus

Turdue

Turdue

633. 
rlin, 337.

$1,542$.

vee, 500.

168.

k, 482.

osbeak, c07.

381.

inglet, 632.

1.

60.

2.

308.

catcher, 557.

collinus, $\mathbf{5 8 1}$.

oyánocephaliss,

censia, 621 .

ver, 607.

idplper, 501.

a, 624.

wa, 527 .

Wren, 620

10.

104.

31.

633.

0,603 .

hatch, 630.

601.
Sterne hirundo, 469.

Sterna forateri, 469.

Stilt Sandpiper, 600,

Sturnella magna neglecta, 573.

Surf Duck, 484.

Surf Scoter, 484

Surnin caparoch, 546.

Swainson'a Hawk, 529 .

Swallow-tailerl Dnck, 483.

Swallow-tailed Kite. 624.

Swamp Sparrow, 605.

Sjlvania canadenais, 624 .

Sylvenia pasilla, 624.

Symplemia semipalmata, 503.

Syrniam nebulosum, 541.

Tachyciueta bicolor, 610 .

Tenneas6e Warbler, 617.

Titlark, 625.

Totanus flavipes, 502

Totanus meladolencita, 502.

Totanua solltarins, 603

Towee, 607.

Tralll'a Flycatcher, 661.

Tree Duck, 482.

Tree Sparrow, 600 .

Tree Swallow, 610.

Trlnga alpina pacifica, 601.

Tringe balrdil, 800.

Tringa canutua, 500.

Tringa fnscicollls, 600 .

Tringa maculsta, 500 .

Tringe mlnutilla, 601.

Trochilua colubris, 557.

Troglodytea aëdon aztecus, 628.

Troglodstes hlemalis, 609.

Trumpeter Swan, 487.

Turdua aonalaachkro pallasil, 634 .

Turdus fuacescens, 633 .

Turdus fuscescene salio i colus, 633.
Turdna alicia, 633.

Turlua natulatua a w a $\mathbf{n}$ a $\mathrm{ni}$, 633.

Turkes Vulture, 523.

Turnstone, 507.

Tryngitea subruficollis, 505.

Tympenuchns americanus, 514.

Tyrannus tyrannus, 557.

Uiula clnerea, 541.

Urinator aretleus, 468.

Uriustor lumme, 468.

Urinator imber, 467.

Veers, 633 .

Vireo flavifrons, 616

Vireo gilrus, 615 .

Vireo olivacens, 614.

Virginla Rail, 494.

Vireo philadelphicua, 615 .

Vireo solltariua, 616.

Warbllog Vireo, 615.

Wagtall, 621.

Wary, sod.

Wicer Sparrow, 495

Water Thrugh, 621.

Weatern Bobolink, 570.

Western Grebe, 163.

Weatern Horned Owl, 542.

Western House Wren, 628 .

Weatern Mendow-lark, 573.

Weatern Sarannah Spurrow, B94.

Weatern Vespor Sparrow, 502.

Western Wood Pewee, 560.

Whistler, 482.

Whistling Swan, 487.

White-headed Engle, 633.

White Wars, 485.

White-winged Scoter, 484.

White Thrush, 633.

White-naped Bobolink, 570.
White-rnmped. Sandpiper, 500.

White Partridge, 514.

Whooping Crane, 401.

Whlp-poor-will, 553.

White-breasted Swallow, 610 .

White-crowned Sparrow, 598.

White Owl, $5+5$.

White-rumped Shrike, 6i3.

White-tr-oated Sparrow, 698.

White-winged Crossbill, 686.

Whisky Jack, 590.

Widgeon, 476 .

Wild Canars, 586

Will Goose, 486.

Wild Pigeon, 522.

Willet, 503.

Wilaon's Phalarope, 497.

Willow Ptarmican, 514.

Wilson'a Snipe, 408

Wilson'a Thruah, 683.

Wilson's Warbler 624

Willow Warbler, 617

Wlllow Wren, 617.

Winter Wren, 629.

Wia-Ka-ijan, 666.

Wood Duck, 480.

Wood Pewec, 560.

Wren, 632.

Xanthocephalus xanthoceplis.

lus, 571.

Yollow-be!lled Flycatcher, 561.

Tellow-bellied Sepsucker, 550,

Fellow-headed Blackbird, 571.

Yollow.legs, 502.

Fellow Rail, 495.

Yellow-tliroated Vireo, 616.

Fellow Warbl 3r, 617.

Zebaldura macroura, 623.

Zonotrichia elbicollis, 598.

Zonotrichla leucophrya, 608. 




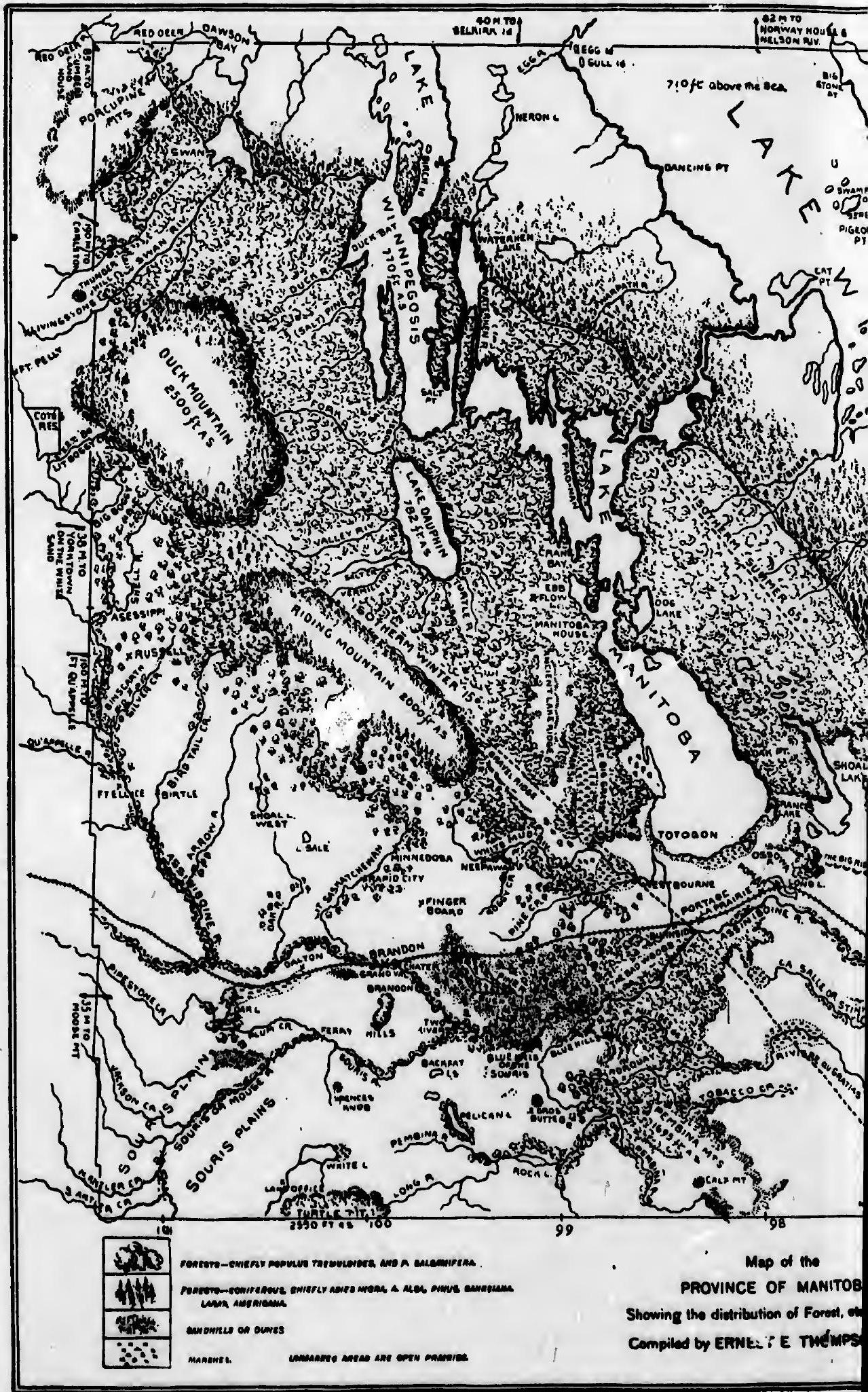




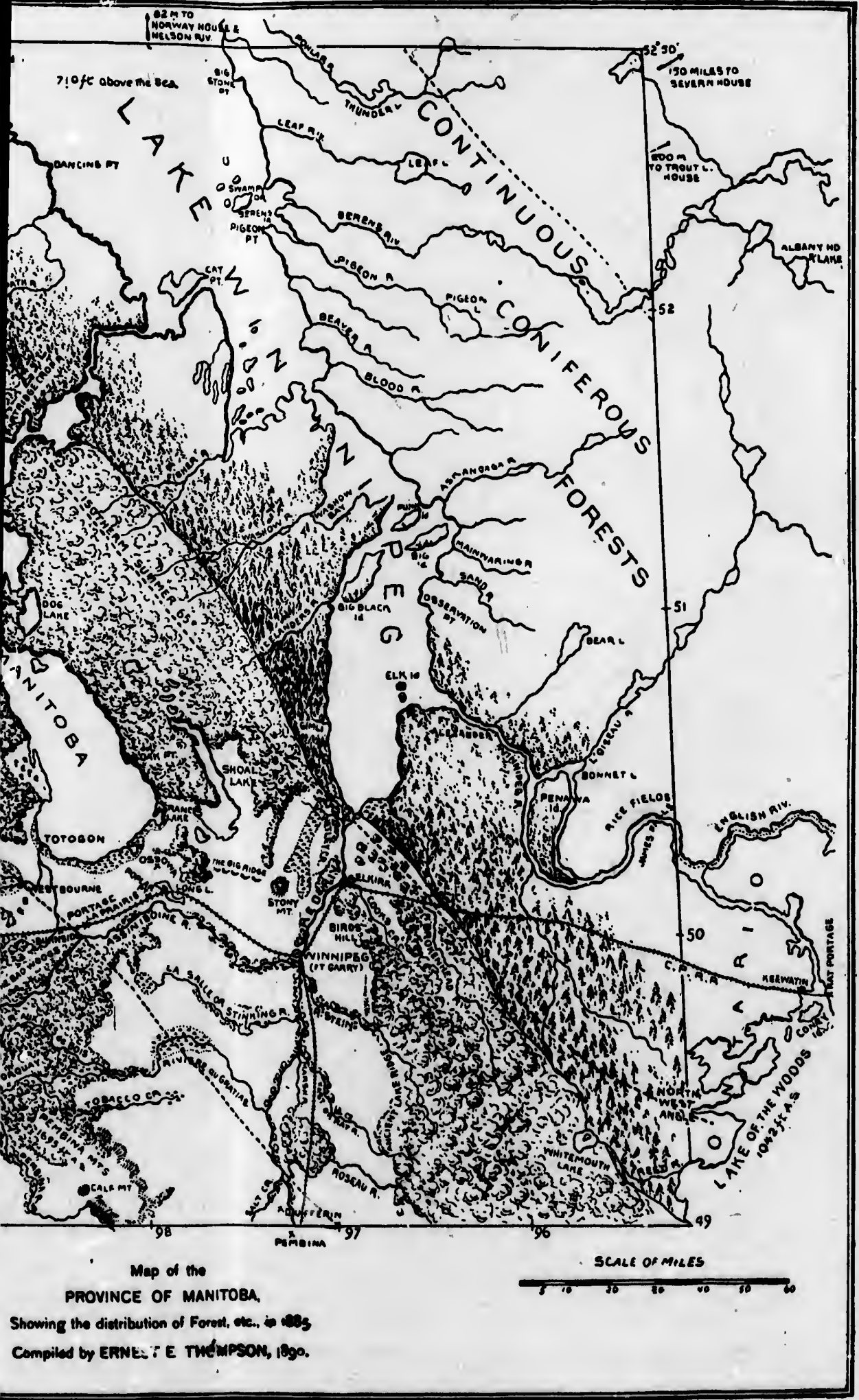




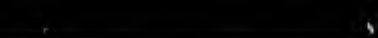

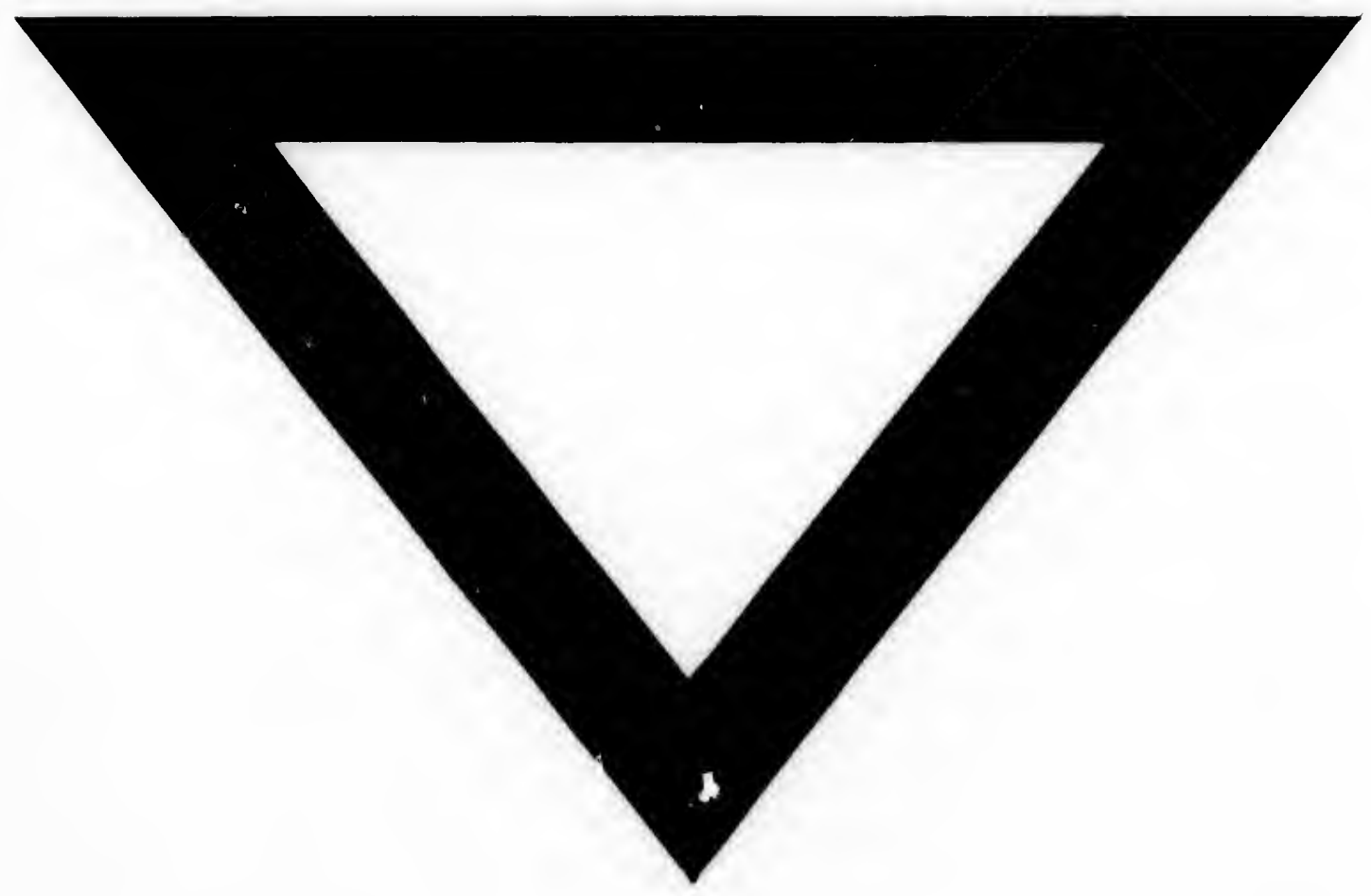

